Prepared for the U.S. Department of Energy

under Contract DE-AC05-76RL01830

\title{
Effects of Time, Heat, and Oxygen on K Basin Sludge Agglomeration, Strength, and Solids Volume
}

\author{
$\mathrm{CH}$ Delegard \\ RC Daniel \\ SI Sinkov \\ CA Burns \\ AJ Schmidt
}

January 2011

\section{Pacific Northwest}

NATIONAL LABORATORY

Proudly Operated by Battelle Since 1965 


\title{
DISCLAIMER
}

This report was prepared as an account of work sponsored by an agency of the United States Government. Neither the United States Government nor any agency thereof, nor Battelle Memorial Institute, nor any of their employees, makes any warranty, express or implied, or assumes any legal liability or responsibility for the accuracy, completeness, or usefulness of any information, apparatus, product, or process disclosed, or represents that its use would not infringe privately owned rights. Reference herein to any specific commercial product, process, or service by trade name, trademark, manufacturer, or otherwise does not necessarily constitute or imply its endorsement, recommendation, or favoring by the United States Government or any agency thereof, or Battelle Memorial Institute. The views and opinions of authors expressed herein do not necessarily state or reflect those of the United States Government or any agency thereof.

\author{
PACIFIC NORTHWEST NATIONAL LABORATORY \\ operated by \\ BATTELLE \\ for the \\ UNITED STATES DEPARTMENT OF ENERGY \\ under Contract DE-ACO5-76RL01830
}

Printed in the United States of America
Available to DOE and DOE contractors from the
Office of Scientific and Technical Information,
P.O. Box 62, Oak Ridge, TN 37831-0062;
ph: (865) 576-8401
fax: (865) 5765728
email: reports@adonis.osti.gov

\footnotetext{
Available to the public from the National Technical Information Service, U.S. Department of Commerce, 5285 Port Royal Rd., Springfield, VA 22161 ph: (800) 553-6847 fax: (703) 605-6900

email: orders@nits.fedworld.gov online ordering: http://www.ntis.gov/ordering.htm
} 


\title{
Effects of Time, Heat, and Oxygen on $\mathrm{K}$ Basin Sludge Agglomeration, Strength, and Solids Volume
}

\author{
CH Delegard \\ RC Daniel \\ SI Sinkov \\ CA Burns
}

AJ Schmidt

January 2011

Prepared for

the U.S. Department of Energy

under Contract DE-AC05-76RL01830

Pacific Northwest National Laboratory

Richland, Washington 99352 


\section{Abstract}

Sludge disposition will be managed in two phases under the K Basin Sludge Treatment Project. The first phase is to retrieve the sludge that currently resides in engineered containers in the K West (KW) Basin pool at $\sim 10$ to $18^{\circ} \mathrm{C}$. The second phase is to retrieve the sludge from interim storage in the sludge transport and storage containers (STSCs) and treat and package it in preparation for eventual shipment to the Waste Isolation Pilot Plant. The work described in this report was conducted to gain insight into how sludge may change during long-term containerized storage in the STSCs. To accelerate potential physical and chemical changes, the tests were performed at temperatures and oxygen partial pressures significantly greater than those expected in the T Plant canyon cells where the STSCs will be stored. Tests were conducted to determine the effects of $50^{\circ} \mathrm{C}$ oxygenated water exposure on settled quiescent uraninite $\left(\mathrm{UO}_{2}\right)$ slurry and a full simulant of $\mathrm{KW}$ containerized sludge to determine the effects of oxygen and heat on the composition and mechanical properties of sludge. Shear-strength measurements by vane rheometry also were conducted for $\mathrm{UO}_{2}$ slurry, mixtures of $\mathrm{UO}_{2}$ and metaschoepite $\left(\mathrm{UO}_{3} \cdot 2 \mathrm{H}_{2} \mathrm{O}\right)$, and for simulated KW containerized sludge. The results from these tests and related previous tests are compared to determine whether the settled solids in the $\mathrm{K}$ Basin sludge materials change in volume because of oxidation of $\mathrm{UO}_{2}$ by dissolved atmospheric oxygen to form metaschoepite. The test results also are compared to determine if heating or other factors alter sludge volumes and to determine the effects of sludge composition and settling times on sludge shear strength. It has been estimated that the sludge volume will increase with time because of a uranium metal $\rightarrow$ uraninite $\rightarrow$ metaschoepite oxidation sequence. This increase could increase the number of containers required for storage and increase overall costs of sludge management activities. However, the volume might decrease because of decreases in the water-volume fraction caused by sludge solid reactions, compaction, or intergrowth and recrystallization of metaschoepite. In that case, fewer STSCs may be needed, but the shear strength would increase, and this could challenge recovery by water jet erosion and require more aggressive retrieval methods. Overall, the tests described herein indicate that the settled solids volume remains the same or decreases with time. The only case for which the sludge solids volumes increase with time is for the expansion factor attendant upon the anoxic corrosion of uranium metal to produce $\mathrm{UO}_{2}$ and subsequent reaction with oxygen to form equimolar $\mathrm{UO}_{2.25}$ and $\mathrm{UO}_{3} \cdot 2 \mathrm{H}_{2} \mathrm{O}$. 



\section{Summary}

Sludge disposition will be managed in two phases under the K Basin Sludge Treatment Project (STP). The first phase is to retrieve the sludge that currently resides in engineered containers in the K West (KW) Basin pool at $\sim 10$ to $18^{\circ} \mathrm{C}$. The retrieved sludge will be hydraulically moved into sludge transport and storage containers (STSCs), and the containers will be transported to T Plant and placed into cells that are equipped with secondary containment and leak-detection systems. This interim storage period will be 10 years or longer. In the second phase of the STP, sludge will be retrieved from interim storage in the STSCs and treated and packaged in preparation for eventual shipment to the Waste Isolation Pilot Plant (WIPP).

The chemical and physical properties of $\mathrm{K}$ Basin sludge are expected to change with time because of chemical reactions whose rates increase with increasing temperature. Changes in settled solids volume and in solids strength with time can impact the planned STSC filling level as well as the intensity and specialized equipment needed for sludge retrieval from the KW Basin containers and T Plant STSCs. The volumes occupied by the settled-sludge solids potentially can increase because of chemical reactions, the most important of which are uranium metal corrosion to form uranium dioxide and the subsequent oxidation of uranium dioxide by oxygen to form metaschoepite. These reactions and other reactions in the sludge can affect the sludge strength by intergrowth of sludge phase crystals and by compaction of the sludge solids, increasing the solids fraction in the settled sludge.

The work described in this report was conducted to gain insight into how sludge may change during long-term containerized storage in the STSCs. To accelerate potential physical and chemical changes, the tests were performed at temperatures and oxygen partial pressures significantly greater than those expected in the T Plant canyon cells. The T Plant canyon temperatures range from $-7^{\circ} \mathrm{C}$ to $32^{\circ} \mathrm{C}$. Uranium-containing simulants used for this work were designed to match the chemical compositions of KW containerized and KW settler sludges. The KW containerized sludge simulant contained uraninite, metaschoepite, aluminum hydroxide, ferrihydrite, Hanford sand, organic ion exchange resin, mordenite inorganic ion exchanger, flocculating agent, and water. The compositions simulating KW settler sludge contained uraninite and water or uraninite, metaschoepite, and water only.

Results of tests conducted to determine the effects of $50^{\circ} \mathrm{C}$ oxygenated water exposure on settled quiescent uraninite $\left(\mathrm{UO}_{2}\right)$ slurry and a full simulant of $\mathrm{KW}$ containerized sludge are reported in the present study. Results of additional tests of heating of the same wetted sludge solids materials to $95^{\circ} \mathrm{C}$ without additional oxygen also are provided. The tests were conducted to determine the effects of oxygen and heat on sludge composition and mechanical properties. Shear-strength measurements by vane rheometry also were conducted for $\mathrm{UO}_{2}$ slurry, mixtures of $\mathrm{UO}_{2}$ and metaschoepite $\left(\mathrm{UO}_{3} \cdot 2 \mathrm{H}_{2} \mathrm{O}\right)$, and for simulated KW containerized sludge. The results from these tests and related previous tests are compared to determine whether the settled solids in the $\mathrm{K}$ Basin sludge materials change in volume because of oxidation of $\mathrm{UO}_{2}$ by dissolved atmospheric oxygen to form metaschoepite. The test results also are compared to determine if heating or other factors alter sludge volumes and to determine the effects of sludge composition and settling times on sludge shear strength.

Stoichiometric calculations based on compound particle density show that uranium solids particle volumes necessarily increase by the uranium metal $\rightarrow$ uraninite $\rightarrow$ metaschoepite oxidation sequence 
observed in K Basin sludge. All other major sludge compounds (e.g., gibbsite, ferrihydrite, sand, ion exchange media) are chemically stable and of low solubility and, therefore, are not expected to alter during extended storage. If the inter-particle porosity of settled sludge, reflected as volume fraction of water, does not change during these uranium oxidation processes, the volume of settled sludge must increase. Previous conservative estimates of sludge expansion presented in the Sludge Technical Databook are based on the assumption that the volume fraction of water remains constant at about 0.75 or increases as sludge constituents oxidize with the effect that settled $\mathrm{K}$ Basin sludge is predicted to increase in volume with an increase in storage time. This increase, in turn, decreases the projected allowable sludge container fill levels for those sludge types in which fill levels are constrained by volume rather than thermal and gas generation limits. The fill-level constraints can increase the number of containers required for storage and increase overall costs of both the Phase 1 and Phase 2 sludge management activities.

However, if the interstitial water-volume fraction decreases because of sludge solid reactions, compaction, or intergrowth and recrystallization of metaschoepite, then fewer STSCs might be needed, but settled-sludge strength would be expected to increase similarly to how kaolin-water mixtures increase in shear strength as the solid fraction increases. If sludge strengthens significantly during storage, recovery by water jet erosion may be challenged and necessitate the use of more aggressive retrieval methods.

Observations from experiments performed under this testing and observations gathered from associated previous testing of genuine sludge materials show that, for the systems studied, the settled solids volume remains the same or decreases with time. The sludge volume decreases as uraninite oxidizes to metaschoepite in uranium-only simulated sludge mixtures, in full sludge simulants, and in genuine sludge. Settled uraninite/metaschoepite/water particulate mixtures have the highest shear strength for blends having the highest solids volume fraction.

Specific results from the analyses provided in this report and prior studies and their importance to $K$ Basin storage and processing are summarized by the following points:

- Oxidation of settled uraninite slurry to metaschoepite by dissolved oxygen produces no increase in settled volume. Metaschoepite product crystals form from the top-down and then knit together to form a continuous layer through Ostwald ripening. No change in total settled solids volume was observed for the $\sim 300$-day experimental duration in accelerated static testing conducted at $51{ }^{\circ} \mathrm{C}$ under a pure oxygen atmosphere.

- The oxidation of uraninite under static $51{ }^{\circ} \mathrm{C}$ pure oxygenated conditions progresses very slowly and appears to be diffusion-limited as shown by its kinetic behavior. Only the top $5 \mathrm{~mm}$ of the sludge bed was oxidized to metaschoepite after nearly 10 months of exposure. The projected metaschoepite solids layer depth under $20^{\circ} \mathrm{C}$ atmospheric oxygen conditions $\left(\mathrm{P}_{\mathrm{O} 2}=0.21 \mathrm{~atm}\right)$ is $\sim 5 \mathrm{~mm}$ after 30 years. The product metaschoepite solids layer at this thickness is weak and friable.

- A previous 28-month-long storage test conducted with six K Basin sludge samples at $\sim 30 \pm 5^{\circ} \mathrm{C}$ under hot cell conditions showed that the settled solids volume decreased or remained essentially unchanged with storage time after an initial 4 days of settling. After the 28 -month settling, five of the sludge samples were readily re-suspended to pourable slurries by agitation. However, the sixth sludge, a uranium-rich fuel canister sludge sample called 96-13, was estimated to have a bulk shear strength of $15 \mathrm{kPa}$ to $65 \mathrm{kPa}$ and could be retrieved from its glass test vessel only by breaking the vessel. 
These findings indicate that for solids very rich in uranium ( $\gtrsim 70$ to $80 \mathrm{wt} \%$, dry basis), long-term storage under aerated non-agitated conditions will form a thin metaschoepite crust that is readily broken. The underlying material may compact somewhat with time, but, because little appreciable change in settled solids strength was seen after nearly a year of settling at $51^{\circ} \mathrm{C}$ in laboratory tests, little increase in strength, beyond that associated with any compaction, is anticipated during lower temperature but longer term storage.

The observations from the 28-month settling test with uranium-rich genuine sludge and the studies with the uraninite oxidation suggest that metaschoepite crystal ripening and intergrowth may have been responsible for the uncommon strength found in the genuine sludge. In this case, the presence of relatively high amounts of metaschoepite within the settled solids layer likely was necessary to produce the strong product material.

Based on these findings, $K$ Basin sludges rich in metaschoepite [ $\gtrsim 70$ to $80 w t \% U$ as $U(V I)$, dry basis] may self-cement by Ostwald ripening to produce strong agglomerates similar to the behavior shown by the 96-13 sludge in the 28-month settling tests. Because of the low solubility of $\mathrm{UO}_{2}$, similar gains in strength by Ostwald ripening for $\mathrm{UO}_{2}$-rich sludge cannot occur.

- Under $51{ }^{\circ} \mathrm{C}$ oxygenated conditions, a full $\mathrm{KW}$ containerized sludge simulant containing gibbsite, ferrihydrite, mordenite, organic ion exchange resin, Hanford sand, and $\sim 50 \% / 50 \% \mathrm{UO}_{2} / \mathrm{UO}_{3} \cdot 2 \mathrm{H}_{2} \mathrm{O}$ decreased in settled solids volume by about $25 \%$ over 106 days while a parallel control test run in the absence of oxygen decreased only about 3\%. The volume decrease coincided with the oxidation of $\mathrm{UO}_{2}$ to $\mathrm{UO}_{3} \cdot 2 \mathrm{H}_{2} \mathrm{O}$ and may have been due to better solids packing or coagulation of non-uranium solids with the crystallizing $\mathrm{UO}_{3} \cdot 2 \mathrm{H}_{2} \mathrm{O}$. However, even though the $\mathrm{KW}$ containerized sludge simulant compacted with time, the strength remained low.

- Under warm $\left(30 \pm 5^{\circ} \mathrm{C}\right)$ semi-oxic conditions, the uraninite in uranium-rich $\mathrm{K}$ Basin sludge samples oxidized to metaschoepite and other U(VI) phases after 9 years of hot cell storage (Delegard et al. 2007a).

These findings mean that, unlike uraninite-rich sludges that form continuous layers or networks of product metaschoepite upon reaction with oxygen or which already have high metaschoepite concentrations, sludges more dilute in uraninite or metaschoepite likely will be unable to produce continuous metaschoepite layers that inhibit further oxidation or which self-cement to form highstrength agglomerates. Instead, the metaschoepite may act to coagulate non-uranium sludge solids and produce settled solids that are more tightly packed and have a lower settled-solids volume and a lower volume fraction of void water.

The effect of decreased water-void volume may be to increase the settled-sludge strength. However, the long-range binding of sludge solids through metaschoepite recrystallization with itself will not be possible because of insufficient metaschoepite. Marked strength increases were not noticeable for the simulated sludge materials tested after $\sim 100$ days of reaction.

- Under strongly stirred oxygenated room temperature conditions, uraninite oxidation produces $\sim 50 \% / 50 \%$ (mole basis) uraninite/metaschoepite settled solids mixtures of significantly higher solids loading ( $\sim 24$ volume $\%$ ) and shear strength than the starting uraninite material and the product metaschoepite. A shear strength in excess of 26,000 $\mathrm{Pa}$ was noted for one such mixture, and shear strengths of $2000 \mathrm{~Pa}$ were routinely observed for similar mixtures. In contrast, pure uraninite and metaschoepite settled slurries had shear strengths measured in the hundreds of $\mathrm{Pa}$. The higher solids 
loading likely is because of better packing of the finer uraninite settled solids within the interstitial pores of the larger metaschoepite crystals.

- The shear strengths of duplicate simulated KW containerized sludge, which contains a variety of sludge components, ranged from 500 to $700 \mathrm{~Pa}$.

- Previous K Basin sludge shear-strength measurements establish the 1 to 8,200 Pa range provided in the Sludge Technical Databook (Schmidt 2010). The shear strength is affected by sample history and generally increases with increasing undisturbed settling time. Within settling times ranging from several days to several weeks, shear strengths ranged from less than $100 \mathrm{~Pa}$ to about 3,000 $\mathrm{Pa}$ and had $240,4,000,1,000,400$, and 8,200 Pa shear strengths after 20 to 30 days settling while containing, respectively, 1.7, 5, 6, 17, and 60 dry basis wt\% uranium (Poloski et al. 2002).

- Shear strengths measured in 2009 for samples from the KW containers SCS-CON-240, 250, and 260 that passed through 500- $\mu \mathrm{m}$ sieves and settled for several days to several weeks were about 300, 300, and $80 \mathrm{~Pa}$, respectively. ${ }^{(\mathrm{a})}$ The total uranium concentrations for the same respective materials were $4.91,5.25$, and $6.61 \mathrm{wt} \%$ (dry basis). The shear strength for the settled $<500-\mu \mathrm{m}$ fraction from SCSCON-220 were $\sim 90 \mathrm{~Pa}$ and $\sim 500 \mathrm{~Pa}$, but the measurements were of low reliability. The dry-basis uranium concentration was $34.6 \mathrm{wt} \%$.

- The better packing of the 50\%/50\% uraninite/metaschoepite mixtures to 24 vol\% volumetric solids fraction is typical of those observed for genuine sludges containing the several other key sludge constituents (e.g., ferrihydrite, gibbsite, sand). Simulated KW containerized sludge samples are relatively weak compared with the 50\%/50\% uraninite/metaschoepite mixtures. However, measurements of actual sludge show no clear trend relating shear strength to uranium concentration, but do indicate increasing shear strength with increased settling time. Shear strengths of genuine sludge can alter because of continued uraninite oxidation and mixing by remobilization and transfer.

- Results from SCS-CON-220, 240, 250, and 260 containerized sludge sample characterization show that the uranium oxide in the sludge is about 50 to $70 \% \mathrm{U}(\mathrm{IV})$, such as uraninite, with the balance being $\mathrm{U}(\mathrm{VI})$, such as metaschoepite or other more mineralized $\mathrm{U}(\mathrm{VI})$ phases. ${ }^{\text {(a) }}$

These recent oxidation state distributions are generally consistent with the uranium oxide compound distributions postulated for starting-state sludge (Schmidt and Sexton 2009; Schmidt and Delegard 2003).

The overall observation that the settled-sludge solids volume remains the same or decreases with time and oxidation means that projections made in the Sludge Technical Databook (Schmidt 2010) are excessively conservative. The only case for which the sludge solids volumes increase with time is for the expansion factor attendant upon the anoxic corrosion of uranium metal to produce $\mathrm{UO}_{2}$ and subsequent reaction with oxygen to form equimolar $\mathrm{UO}_{2.25}$ and $\mathrm{UO}_{3} \cdot 2 \mathrm{H}_{2} \mathrm{O}$.

The revised calculation approach for expansion factors would include the same starting- and end-state uranium compound assignments and include the same mass and volume balance to project the end-state

(a) Fiskum SK, JM Billing, SJ Bos, CA Burns, CD Carlson, DS Coffey, JV Crum, RC Daniel, CH Delegard, MK Edwards, OT Farmer, LR Greenwood, SA Jones, D Neiner, BM Oliver, KN Pool, AJ Schmidt, RW Shimskey, CZ Soderquist, CJ Thompson, ML Thomas, T Trang-Le, and MW Urie. 2009. Characterization Data Package for Containerized Sludge Samples Collected from Engineered Containers SCS-CON-240, 250, 260, and 220. PNNL-19035 (Limited Distribution), Pacific Northwest National Laboratory, Richland, Washington. 
sludge solids composition. Based on measurements of sludge sample volume during long-term storage and volume measurement in testing under oxidizing conditions accelerated by increased temperature and increased oxygen partial pressure, the starting state and end state of settled-sludge volumes would be held constant with the exception of volume accounting to address $U$ metal anoxic corrosion and subsequent reaction with oxygen to form equimolar $\mathrm{UO}_{2.25}$ and $\mathrm{UO}_{3} \cdot 2 \mathrm{H}_{2} \mathrm{O}$. To account for the volumetric expansion resulting from uranium metal, the mass of uranium metal in the starting-state sludge would be multiplied by the projected volume expansion of $0.8 \mathrm{~cm}^{3}$ end state of settled sludge per gram of $U$ metal for fuelpiece sludge $^{(\mathrm{a})}$ given in the Sludge Technical Databook.

(a) Fuel piece sludge is material that meets the $\leq 1 / 4$ inch size criterion for sludge but is composed largely of irradiated uranium metal fuel. 



\section{Acronyms}

$\begin{array}{ll}\text { ALE } & \text { Fitzner-Eberhardt Arid Lands Ecology Reserve } \\ \text { BTR } & \text { buyer's technical representative } \\ \text { DI } & \text { deionized (water) } \\ \text { KE } & \text { K East (Basin) } \\ \text { KW } & \text { K West (Basin) } \\ \text { OIER } & \text { organic ion exchange resin } \\ \text { PCB } & \text { polychlorinated biphenyl } \\ \text { PNNL } & \text { Pacific Northwest National Laboratory } \\ \text { SEM } & \text { scanning electron microscopy } \\ \text { SNF } & \text { special nuclear fuels } \\ \text { STP } & \text { Sludge Treatment Project } \\ \text { STS } & \text { Sludge Transport System } \\ \text { STSC } & \text { sludge transport and storage container } \\ \text { TBD } & \text { to be determined } \\ \text { TI } & \text { test instruction } \\ \text { WIPP } & \text { Waste Isolation Pilot Plant } \\ \text { XRD } & \text { X-ray diffractometry }\end{array}$





\section{Contents}

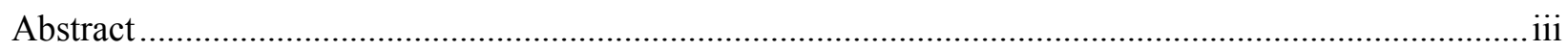

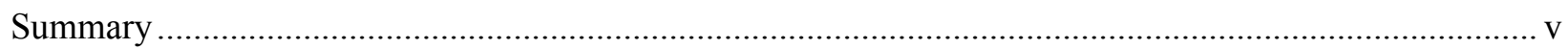

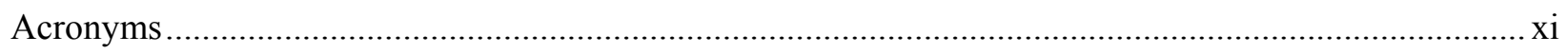

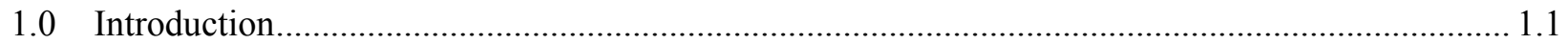

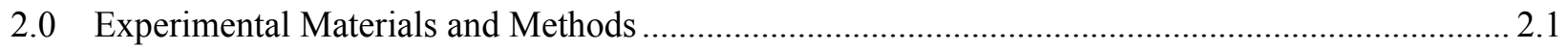

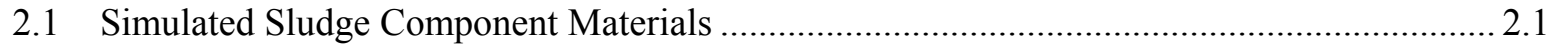

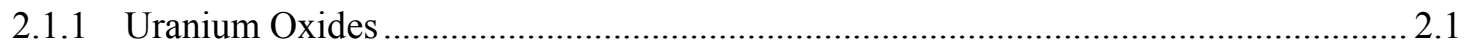

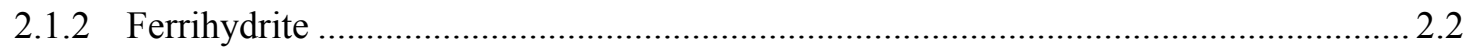

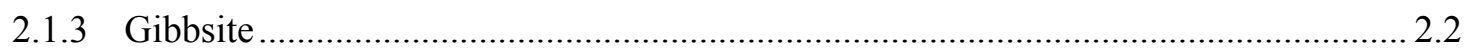

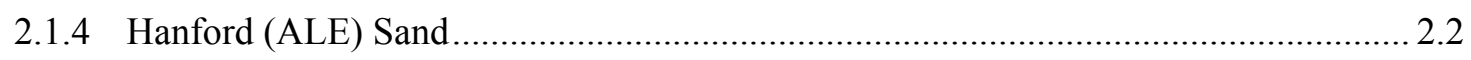

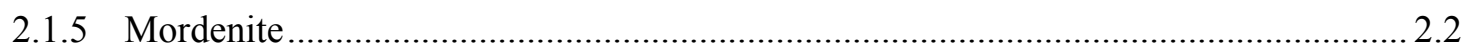

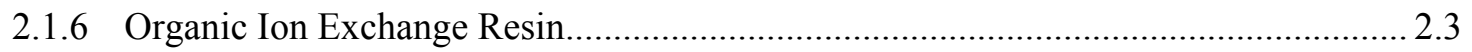

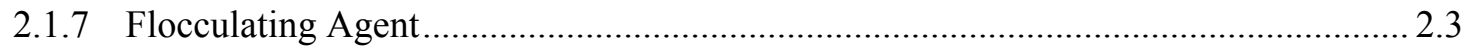

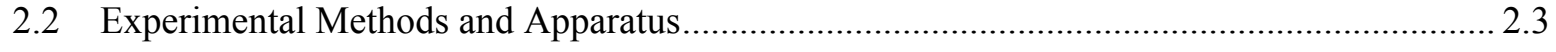

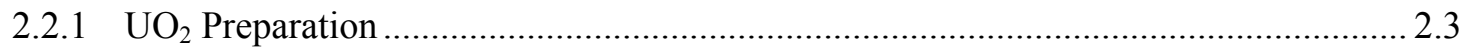

2.2.2 KW Containerized Simulant Sludge Preparation..................................................... 2.4

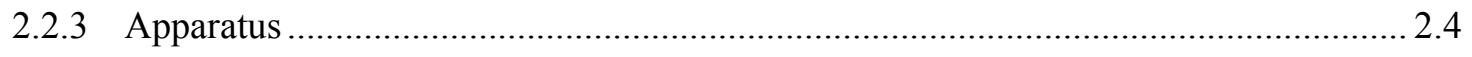

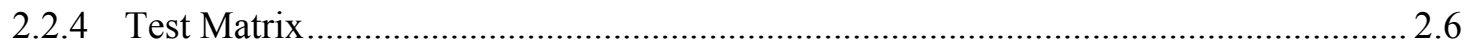

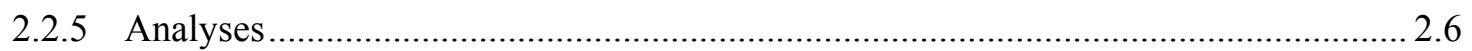

2.2.6 Shear-Strength Measurements of Simulated Sludge and Simulated Sludge

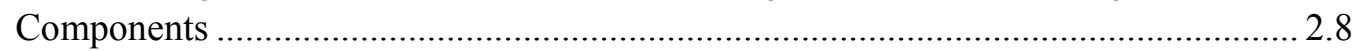

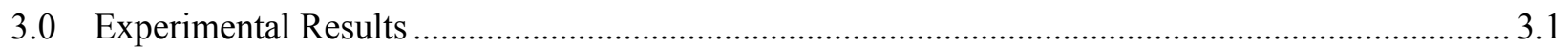

3.1 $\mathrm{UO}_{2}$ and $\mathrm{KW}$ Containerized Sludge Simulant at $51^{\circ} \mathrm{C}$ Under Flowing $\mathrm{O}_{2}$ Gas .................... 3.1

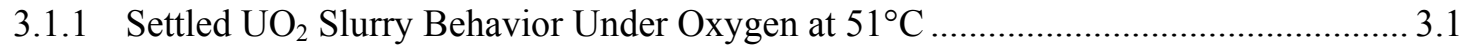

3.1.2 Settled Simulated KW Containerized Sludge Slurry Behavior Under Oxygen

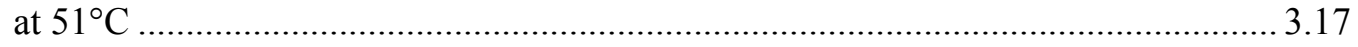

$3.2 \mathrm{UO}_{2} / \mathrm{UO}_{3} \cdot 2 \mathrm{H}_{2} \mathrm{O}$ and KW Containerized Sludge Simulant at $96^{\circ} \mathrm{C}$ Under Static Gas .......... 3.22

3.2.1 Properties of $\mathrm{UO}_{2} / \mathrm{UO}_{3} \cdot 2 \mathrm{H}_{2} \mathrm{O}$ and KW Containerized Sludge Simulant Heated

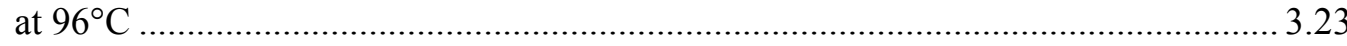

3.2.2 Appearances of $\mathrm{UO}_{2} / \mathrm{UO}_{3} \cdot 2 \mathrm{H}_{2} \mathrm{O}$ and $\mathrm{KW}$ Containerized Sludge Simulant

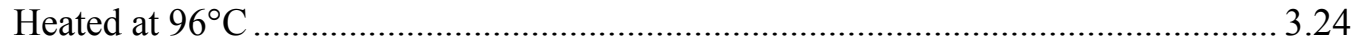

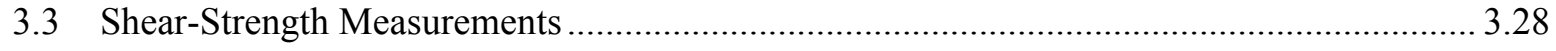

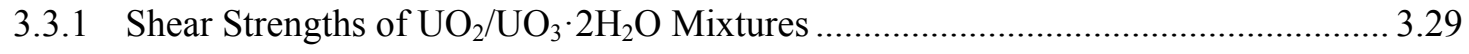

3.3.2 Densities and Volume Fractions of $\mathrm{UO}_{2} / \mathrm{UO}_{3} \cdot 2 \mathrm{H}_{2} \mathrm{O} / \mathrm{H}_{2} \mathrm{O}$ Mixtures ........................ 3.31 
3.3.3 Shear Strengths of KW Containerized Sludge Simulant......................................... 3.35

3.3.4 Shear Strengths of KE Basin and KW Containerized Sludge ................................... 3.35

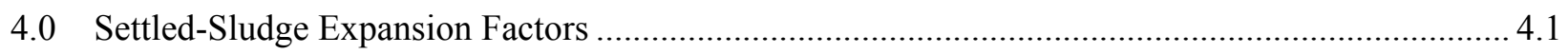

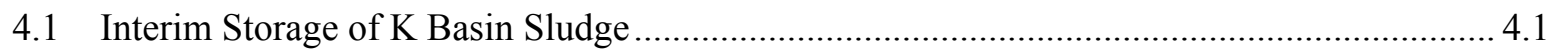

4.2 Review of Databook Corrosion-Based Expansion Factors..................................................... 4.3

4.2.1 Uranium Phase Reactions and Distribution in Sludge ................................................ 4.4

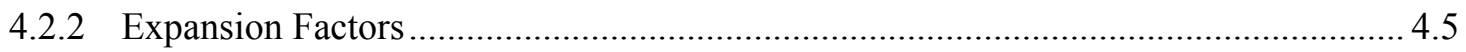

4.3 Volumetric Changes of Sludge Samples During Long-Term Storage.................................. 4.7

4.4 Recommended Changes to the Expansion Factor Calculation Approach............................. 4.9

4.5 Additional Considerations for Future Updates to Databook Expansion-Factor

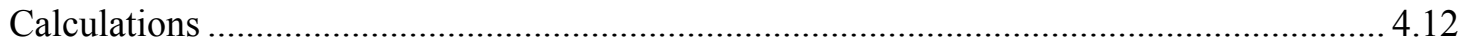

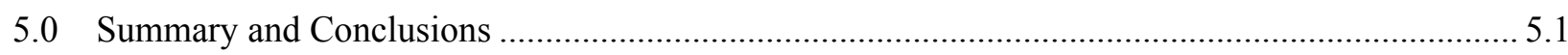

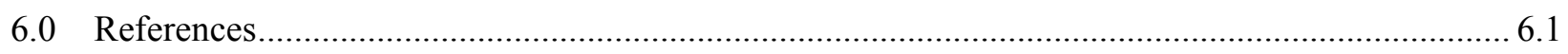

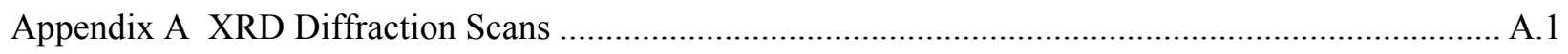

Appendix B Supporting Calculations for Evaluation of Corrosion Based Expansion Factors ..................1 


\section{Figures}

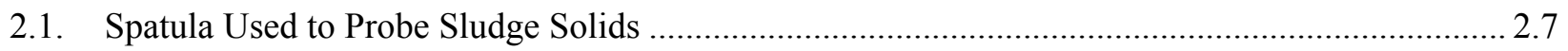

3.1. Settled $\mathrm{UO}_{2}$ Solids in $51^{\circ} \mathrm{C}$ Water Bath After 3 Days of Oxygen Exposure...................................

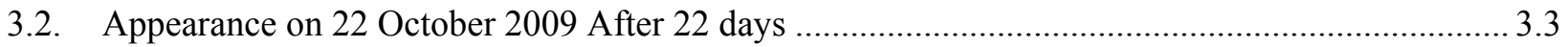

3.3. Appearance on 1 December 2009 after 62 Days ........................................................................ 3.4

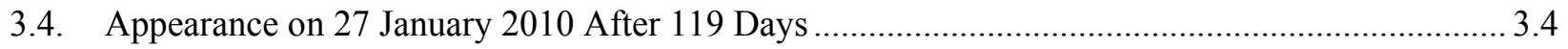

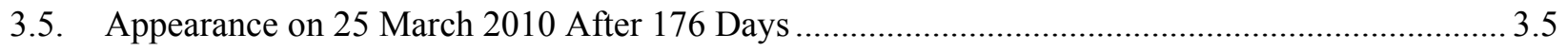

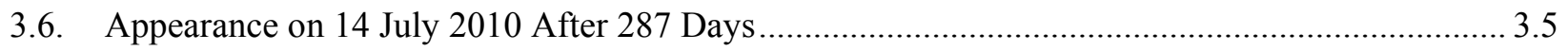

3.7. Test 6 Side/Upper View on 14 July 2010 After 287 Days of Oxygenated Water Exposure........... 3.6

3.8. Appearances of $\mathrm{UO}_{2}$ Aqueous Slurries Being Oxidized by Dissolved Oxygen ............................ 3.7

3.9. Settled $\mathrm{UO}_{2}$ Solids Oxidation to $\mathrm{UO}_{3} \cdot 2 \mathrm{H}_{2} \mathrm{O}$ as Measured by Oxidation Depth with Respect

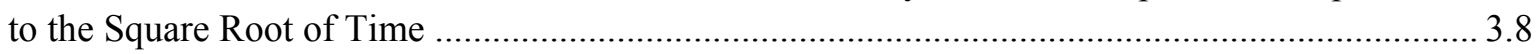

3.10. Depth of Settled $\mathrm{UO}_{2}$ Solids Oxidation to $\mathrm{UO}_{3} \cdot 2 \mathrm{H}_{2} \mathrm{O}$ as a Function of Temperature and

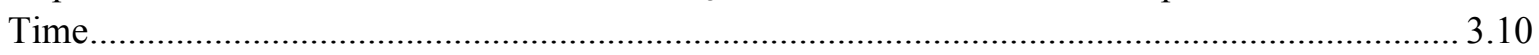

3.11. SEM Image of Loose Green-Yellow Particles Lying at the Top in Test 4................................ 3.12

3.12. SEM Images of Loose Green-Yellow Particles Lying at the Top in Test 4 .............................. 3.13

3.13. SEM Images of Black-Brown Particles Found at the Bottom in Test 4 ...................................... 3.13

3.14. SEM Images of Intergrown Agglomerated Crust Layer Solids in Test 4, 185 Days .................... 3.14

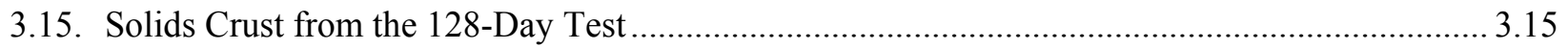

3.16. Liesegang Rings in Basalt (left) and Ignimbrite (right)..................................................... 3.16

3.17. Relative Settled Depths of Non-Flocculated KW Containerized Sludge upon Exposure to

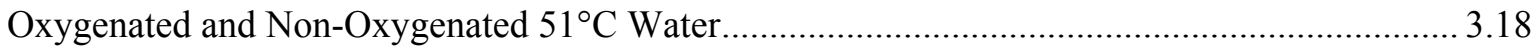

3.18. S-Control and S-4 Tests after 41 Days of Exposure to $51^{\circ} \mathrm{C}$ Oxygenated Water ....................... 3.19

3.19. S-Control and S-4 Tests after 69 Days of Exposure to $51^{\circ} \mathrm{C}$ Oxygenated Water ....................... 3.20

3.20. S-Control and S-4 Tests after 106 Days of Exposure to $51^{\circ} \mathrm{C}$ Oxygenated Water ...................... 3.20

3.21. Oxidation Extent Observed Visually and by Spectrophotometry for KW Containerized

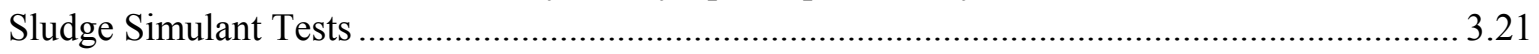

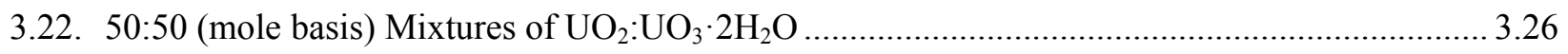

3.23. Test U-1 and U-2 50:50 (mole basis) $\mathrm{UO}_{2}: \mathrm{UO}_{3} \cdot 2 \mathrm{H}_{2} \mathrm{O}$ Mixtures Exposed to $96^{\circ} \mathrm{C}$ for

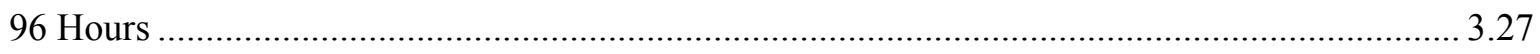

3.24. KW Sludge Simulant after 96 Hours of Exposure to $96^{\circ} \mathrm{C}$..................................................... 3.28

3.25. $\mathrm{UO}_{2} / \mathrm{UO}_{3} \cdot 2 \mathrm{H}_{2} \mathrm{O}$ Samples From Room-Temperature $\mathrm{UO}_{2}$ Oxidation by Oxygen Gas ................. 3.33

3.26. Settled $\mathrm{UO}_{2} / \mathrm{UO}_{3} \cdot 2 \mathrm{H}_{2} \mathrm{O}$ Volume Fraction of Water and Density as Functions of U(VI)

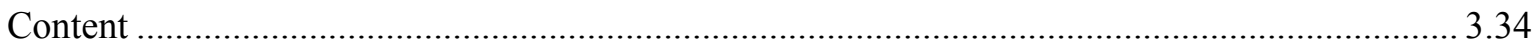

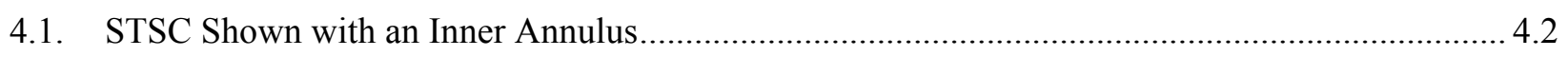

4.2. Settled-Sludge Volume as a Function of Settling Time ........................................................... 4.9 


\section{Tables}

2.1. KW Containerized Simulant Sludge Basis and Composition..................................................... 2.5

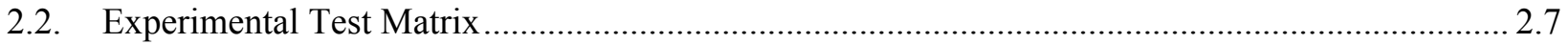

3.1. Settled Volume, Color Change, and Extent of Oxidation for $\mathrm{UO}_{2}$ Solids .................................... 3.2

3.2. Settled Volume, Density, and Extents of Oxidation in KW Containerized Simulant Sludge ....... 3.17

3.3. Settled Density and Solution pH Before and After Heating ..................................................... 3.24

3.4. Test Observations from Warm Water Heating ......................................................................... 3.25

3.5. Shear Strengths of $\mathrm{UO}_{2} / \mathrm{UO}_{3} \cdot 2 \mathrm{H}_{2} \mathrm{O}$ Mixtures and Simulated KW Containerized Sludge............. 3.30

3.6. Volume Fractions of Water, $\mathrm{UO}_{2}$, and $\mathrm{UO}_{3} \cdot 2 \mathrm{H}_{2} \mathrm{O}$ in Uranium Oxide Slurries ........................... 3.33

4.1. Derivation of Corrosion-Based Expansion Factor for KW Settler Sludge .................................... 4.6

4.2. Sludge Samples Used in 28-month Settling Test ................................................................... 4.8

4.3. Derivation of Corrosion-Based Expansion Factor for KW Settler Sludge ................................ 4.13

4.4. Derivation of Corrosion-Based Expansion Factor for KW Containerized Sludge ....................... 4.14

4.5. Derivation of Corrosion-Based Expansion Factor for KE Containerized Sludge ........................ 4.15 


\subsection{Introduction}

Under the K Basin Sludge Treatment Project (STP), sludge disposition will be managed in two phases. The first phase is to retrieve the sludge that currently resides in engineered containers in the $\mathrm{K}$ West (KW) Basin pool. The retrieved sludge will be hydraulically moved into sludge transport and storage containers (STSCs), transported to T Plant for an interim storage period of 10 years or longer, and placed into cells that are equipped with secondary containment and leak-detection systems. In the second phase of the STP, sludge will be retrieved from interim storage and treated and packaged in preparation for eventual shipment to the Waste Isolation Pilot Plant (WIPP).

The chemical and physical properties of the sludge are expected to change with time, and these changes can impact the planned storage and retrieval activities in the KW Basin pool and in T Plant. Two important properties subject to change are the sludge volume and the shear strength. Changes in sludge volume with storage time, particularly increases, affect the allowable filling levels of the sludge containers and the resulting numbers of containers. Sludge shear-strength changes, particularly increases, affect the means necessary to retrieve the sludge from the sludge containers.

The work described in this report was conducted to gain insight into how sludge may change during long-term containerized storage in the STSCs. To accelerate potential physical and chemical changes, the tests were performed at temperatures and oxygen partial pressures significantly greater than those expected in the T Plant canyon cells. Uranium-containing simulants used for this work were designed to match the chemical composition of KW containerized and KW settler sludge.

The volumes occupied by the settled-sludge solids potentially can increase because of chemical reactions, the most important of which are uranium metal corrosion to form uranium dioxide $\left(\mathrm{UO}_{2}\right)$ and the subsequent oxidation of uranium dioxide by oxygen to form metaschoepite $\left(\mathrm{UO}_{3} \cdot 2 \mathrm{H}_{2} \mathrm{O}\right)$. These reactions and other reactions in the sludge can affect the sludge strength by intergrowth of sludge phase crystals and by compaction of the sludge solids, increasing the solids fraction in the settled sludge.

Tests were conducted to determine the effects of $50^{\circ} \mathrm{C}$ oxygenated water exposure on the properties of settled quiescent uranium dioxide slurry and a full simulant of KW containerized sludge. Pure oxygen atmospheres and temperatures higher than T Plant storage were used to accelerate the reactions.

Additional tests of heating of the same wetted sludge solids materials to $95^{\circ} \mathrm{C}$ under stagnant air also were performed. In addition, shear-strength measurements by vane rheometry were conducted for $\mathrm{UO}_{2}$ slurry, mixtures of $\mathrm{UO}_{2}$ and metaschoepite, and simulated $\mathrm{KW}$ containerized sludge. The tests were conducted under client-approved Test Instructions (TIs) and quality programs at Pacific Northwest National Laboratory (PNNL). ${ }^{(a)}$

(a) Delegard CH. 2009. "Volumetric Change in $\mathrm{UO}_{2}$ Oxidation." TI 53451-TI20, Pacific Northwest National Laboratory, Richland, WA. Tests began 21 September 2009.

Delegard CH. 2010. “Oxidation of KW Container Sludge Simulant.” TI 53451-TI24, Rev. 1, Pacific Northwest National Laboratory, Richland, WA. Tests began 24 March 2010.

Delegard CH. 2010. "Oxidation of KW Container Sludge Simulant; Addendum - Agglomeration with Heating.” TI 53451-TI24, Rev. 1, Addendum, Pacific Northwest National Laboratory, Richland, WA. Tests began 16 July 2010. 
The specific objectives of the tests in which the sludge simulants were heated with and without oxygen were to determine whether the settled solids in the $\mathrm{K}$ Basin sludge materials would change in volume because of atmospheric oxygen oxidation of the $\mathrm{UO}_{2}$ present in the sludge to form metaschoepite or because of other mechanisms. The effects of sludge composition and settling/gel time on shear strength also were determined.

The uranium solids particle volumes necessarily increase by oxidation. One gram of uranium metal (density $19.04 \mathrm{~g} / \mathrm{cm}^{3}$; Grenthe et al. 2008) occupies $0.0525 \mathrm{~cm}^{3}$. Anoxic aqueous corrosion of one gram of uranium metal forms hydrogen gas and 1.134 grams of uranium dioxide $\left(\mathrm{UO}_{2}\right.$ or uraninite; density $10.964 \mathrm{~g} / \mathrm{cm}^{3}$; Grenthe et al. 2008), nearly doubling the solids volume to occupy $0.103 \mathrm{~cm}^{3}$.

$$
\mathrm{U}_{(\mathrm{s})}+2 \mathrm{H}_{2} \mathrm{O}_{(\mathrm{l})} \rightarrow \mathrm{UO}_{2(\mathrm{~s})}+2 \mathrm{H}_{2(\mathrm{~g})}
$$

Note that the consequences of this reaction were seen in the mushrooming of the $\mathrm{N}$ Reactor fuel uranium and the splitting of cladding when cladding breaches allowed water to contact the underlying uranium metal.

The product $\mathrm{UO}_{2}$, in turn, is susceptible to further oxidation by exposure to oxygen dissolved in basin waters or to oxygen generated radiolytically. When the 1.134 grams of $\mathrm{UO}_{2}$ reacts with oxygen and water to form 1.353 grams of metaschoepite $\left(\mathrm{UO}_{3} \cdot 2 \mathrm{H}_{2} \mathrm{O}\right.$; density $5.00 \mathrm{~g} / \mathrm{cm}^{3}$; Grenthe et al. 2008), the solids volume increases more than two-fold to occupy $0.271 \mathrm{~cm}^{3}$.

$$
\mathrm{UO}_{2(\mathrm{~s})}+0.5 \mathrm{O}_{2(\mathrm{~g})}+2 \mathrm{H}_{2} \mathrm{O}_{(\mathrm{l})} \rightarrow \mathrm{UO}_{3} \cdot 2 \mathrm{H}_{2} \mathrm{O}_{(\mathrm{s})}
$$

Overall, the complete conversion of uranium metal to metaschoepite increases the solids volume by a factor of 5.16 .

Settled sludge has inter-particle porosity reflected as volume fraction of water. For containerized sludge, the volume fraction of interstitial water is $\sim 0.75$. Previous conservative estimates of sludge expansion presented in the Sludge Technical Databook (Schmidt 2010) are based on the assumption that the volume fraction of water remains constant or increases as sludge constituents oxidize. However, these predicted settled KW Basin sludge volumetric expansions may be overly conservative with the consequence that sludge container fill levels may be conservatively low and the number of containers required for storage high, forcing increased overall costs of both the Phase 1 and Phase 2 sludge management activities.

Instead of the interstitial water volume fraction remaining constant as settled-sludge solids react to swell and thus increase the total settled solids volume, the water-volume fraction may decrease and the solids consolidate to become compacted or develop agglomerates during extended static unmixed storage in STSCs. For example, when the sludge solids volumes increase, sludge overburden pressure (lithostatic

Delegard CH. 2010. "Preparation of Uranium-Containing KW Container Sludge Simulant.” TI 53451-TI21, Pacific Northwest National Laboratory, Richland, WA.

Delegard CH. 2010. "Rheological Measurements for Uraninite-Metaschoepite Mixtures." 53451-TI22, Pacific Northwest National Laboratory, Richland, WA.

Burns CA. 2010. "Rheological Measurements for U-Containing KW Container Sludge Simulant and U Oxide Mixtures." 53451-TI30, Pacific Northwest National Laboratory, Richland, WA. 
head) and horizontal constraint imposed by vertical tank walls may prevent the sludge solids from swelling upward and, instead, may compress the sludge laterally, causing it to squeeze water from the interstitial spaces and thus lower the volume fraction of water while maintaining the total settled-solids volume. This compression could increase the strength of the settled sludge much as compression increases the strength of snow to make a snowball or glacier.

Even without compression, replacing a portion of the interstitial water with solids would be expected to increase the settled-sludge strength. If the KW sludge behaves as kaolin-water mixtures (Burns et al. 2010) or simulated non-radioactive KW containerized sludge (Gauglitz et al. 2010), then a linear increase of solids fraction would result in an exponential increase in shear strength. Intergrowth and bridging of the freshly formed $\mathrm{UO}_{3} \cdot 2 \mathrm{H}_{2} \mathrm{O}$ or other $\mathrm{U}(\mathrm{VI})$ phases into themselves or the settled $\mathrm{UO}_{2}$ also can increase strength by self-cementation.

If sludge strengthens, its retrieval from the STSCs by water jet erosion may be challenged with the potential effects of decreased retrieval rates and the required use of more aggressive retrieval methods.

Observations from experiments performed under this testing and gathering of associated observations from previous testing of genuine sludge materials are interpreted in this report to provide information on settled-solids volume changes and changes in the solids character because of oxidation of $\mathrm{UO}_{2}$ to $\mathrm{UO}_{3} \cdot 2 \mathrm{H}_{2} \mathrm{O}$ by dissolved oxygen, by heating, and by other phenomena. Data on the shear strengths of settled simulated sludge also are gathered to help estimate shear strengths for actual sludge and to determine the effects of sludge composition and settling times on strength. 


\subsection{Experimental Materials and Methods}

The components used in the testing are described in Section 2.1, and the experimental methods are described in Section 2.2.

\subsection{Simulated Sludge Component Materials}

Uranium-rich sludges primarily contain $\mathrm{U}$ metal, $\mathrm{UO}_{2}$, and $\mathrm{UO}_{3} \cdot 2 \mathrm{H}_{2} \mathrm{O}$ solid phases and interstitial and supernatant water. Other U(VI) phases may be present in aged and more mineralized sludge. Even for uranium-rich sludges, the volumetric $U$ metal portion is small because of its high density such that the settled volumes of uranium-rich sludge are dominated by $\mathrm{UO}_{2}, \mathrm{UO}_{3} \cdot 2 \mathrm{H}_{2} \mathrm{O}$, and interstitial water. No uranium metal was used in the present testing. The tests of $\mathrm{UO}_{2}$ oxidation by dissolved $\mathrm{O}_{2}$ were performed using only $\mathrm{UO}_{2}$ solids slurry and distilled and deionized (DI) water. The tests with simulated $\mathrm{KW}$ containerized sludge used the principal components found in sludge- $\mathrm{UO}_{2}, \mathrm{UO}_{3} \cdot 2 \mathrm{H}_{2} \mathrm{O}$, ferrihydrite, gibbsite, Hanford sand, organic and inorganic ion exchange media, DI water, and, for some tests, Optimer 7194 Plus flocculant (compositions based on Delegard et al. 2007a, 2007b, and references therein).

The ferrihydrite $\left[\mathrm{Fe}_{5} \mathrm{O}_{7}(\mathrm{OH}) \cdot 4 \mathrm{H}_{2} \mathrm{O}\right.$, expressed more simply as $\left.\mathrm{Fe}_{2} \mathrm{O}_{3} \cdot 1.8 \mathrm{H}_{2} \mathrm{O}\right]$ and other iron (hydr)oxides such as goethite and hematite ( $\mathrm{FeOOH}$ and $\mathrm{Fe}_{2} \mathrm{O}_{3}$, respectively) in $\mathrm{KW}$ containerized sludge arise from corrosion of mild steel structural components. Gibbsite and other aluminum hydroxide $\left[\mathrm{Al}(\mathrm{OH})_{3}\right]$ components arise from aluminum component corrosion. The Hanford sand was in-blown into the Basins from the surrounding soil while the ion exchange media, including Purolite NRW37 organic ion exchange resin and Norton Zeolon 900 (mordenite) inorganic ion exchanger, were used in maintaining $\mathrm{K}$ Basin water quality. The flocculating agent was used to control particle dispersion and improve settling during sludge solids transfer operations.

Metaschoepite, $\mathrm{UO}_{3} \cdot 2 \mathrm{H}_{2} \mathrm{O}$, mineralizes according to well-known reactions in the $\mathrm{K}$ Basin to form more complex $\mathrm{U}(\mathrm{VI})$ phases. Among the $\mathrm{U}(\mathrm{VI})$ phases arising from metaschoepite mineralization found in genuine sludge are becquerelite $\left[\mathrm{Ca}\left(\mathrm{UO}_{2}\right)_{6} \mathrm{O}_{4}(\mathrm{OH})_{6}\left(\mathrm{H}_{2} \mathrm{O}\right)_{8}\right]$, formed by reacting with calcite $\left(\mathrm{CaCO}_{3}\right)$; soddyite $\left[\left(\mathrm{UO}_{2}\right)_{2} \mathrm{SiO}_{4} \cdot 2 \mathrm{H}_{2} \mathrm{O}\right]$, formed by reacting with silica $\left(\mathrm{SiO}_{2}\right)$; and metastudtite $\left[\left(\mathrm{UO}_{2}\right) \mathrm{O}_{2}\left(\mathrm{H}_{2} \mathrm{O}\right)_{2}\right.$, a uranyl peroxide], formed by reacting with radiolytic peroxide. Other components found in the sludge include Zircaloy cladding bits, Grafoil (a largely graphite gasket material produced as a tape $\sim 3 / 4$-inch in width), paint chips, plastic debris (e.g., plastic bags and sheeting), hydraulic oil, trace polychlorinated biphenyls (PCBs), and biological matter (insects, grass, twigs). These minor components, mineralized $\mathrm{U}(\mathrm{VI})$ phases, and uranium metal were not included in the simulated KW containerized sludge used in the present testing.

\subsubsection{Uranium Oxides}

The $\mathrm{UO}_{2}$ [oxidation state of $\mathrm{U}(\mathrm{IV})$ ] used in testing was prepared in 2007 under PNNL direction by Manufacturing Sciences Corporation of Oak Ridge, Tennessee, by reaction of high-purity (99.96 wt \%) uranium metal turnings in $\sim 60{ }^{\circ} \mathrm{C}$ water. The source uranium metal was $0.19 \%{ }^{235} \mathrm{U}$ (i.e., of depleted enrichment). The $\mathrm{UO}_{2}$ has been stored underwater in closed jars since preparation to prevent further oxidation. Previous characterization showed this material to be nearly stoichiometric $\mathrm{UO}_{2}$ and to have a nominal 6-nm-diameter particle size with smaller particles and larger agglomerates (Sinkov et al. 2008). 
PNNL staff prepared the target $50 \% \mathrm{U}(\mathrm{IV})$ and $50 \% \mathrm{U}(\mathrm{VI})$ oxidation state $\mathrm{UO}_{2}: \mathrm{UO}_{3} \cdot 2 \mathrm{H}_{2} \mathrm{O}$ mixtures by oxidizing $\mathrm{UO}_{2}$ with sparging oxygen gas through the slurry at room temperature until the desired 50:50 mole\% composition was reached. Preparations of the U(IV):U(VI) mixtures were conducted within the applicable Test Instructions (53451-TI24 Rev. 1 and 53451-TI24 Rev. 1 Addendum). The actual uranium oxidation state distributions and the concentrations of total uranium and $\mathrm{U}(\mathrm{IV})$ and $\mathrm{U}(\mathrm{VI})$ in the slurries were determined according to an internal PNNL analytical procedure. ${ }^{(a)}$

\subsubsection{Ferrihydrite}

The ferrihydrite, identified as ferric oxide hydroxide (Shepherd Chemical Company), was analyzed by the vendor to be poorly crystalline 6-line ferrihydrite by X-ray diffractometry (XRD). Subsequent XRD analysis by PNNL showed that no observable 6-line ferrihydrite was present and that the solids had transformed to goethite and hematite (Sinkov et al. 2010). Tests of the $\mathrm{pH}$ of slurries of this material have shown it to be alkaline (i.e., $\mathrm{pH} \sim 12$ ). Because the alkalinity could affect simulated sludge properties, the ferrihydrite was washed with DI water several times before use by repeated sequential steps of water addition, stirring, settling, and decanting, followed by air-drying once the $\mathrm{pH}$ became less than 8 .

\subsubsection{Gibbsite}

The aluminum hydroxide used in testing was reagent grade (JT Baker, now Mallinckrodt Baker, Inc.) and has been identified by PNNL XRD to be gibbsite.

\subsubsection{Hanford (ALE) Sand}

The finely granular to powdery Hanford blow sand used in the testing was collected from the FitznerEberhardt Arid Lands Ecology (ALE) Reserve in July 2007 between mileposts 9 and 10 on the south side of State Highway 240, about 12 miles south of the KW Basin. According to XRD analysis (Sinkov et al. 2010), the sand contained quartz $\left(\mathrm{SiO}_{2}\right)$, anorthite $\left(\mathrm{CaAl}_{2} \mathrm{Si}_{2} \mathrm{O}_{8}\right)$, microcline $\left(\mathrm{KAlSi}_{3} \mathrm{O}_{8}\right)$, mica $\left[\mathrm{KFe}_{3}\left(\mathrm{Al}_{0.24} \mathrm{Fe}_{0.76} \mathrm{Si}_{3}\right) \mathrm{O}_{10}(\mathrm{OH})_{2}\right]$, and aegerine $\left(\mathrm{Fe}_{0.5185} \mathrm{Al}_{0.4185} \mathrm{Ca}_{0.466} \mathrm{Na}_{0.534} \mathrm{Si}_{2} \mathrm{O}_{6}\right)$. Non-crystalline or glassy phases found in basalt are ubiquitous in the Hanford soils but are not seen by XRD. The observed mineral distribution is similar to the quartz, feldspar (e.g., albite and anorthite), basalt, mica (muscovite, biotite), clay (chlorite, smectite), and accompanying calcite constituents typical of Hanford soils (Serne et al. 2002, and references therein; Schmidt et al. 1999; Zachara et al. 2002).

\subsubsection{Mordenite}

The mordenite used in the testing is sodium mordenite LZM-5 from UOP, LLC. This material was selected to substitute for the Norton Zeolon 900 mordenite that was used in previous K Basins operations to remove radioactive cesium from the waters. The Norton Zeolon 900 is no longer commercially available. The dry LZM-5, nominally $\mathrm{Na}_{6} \mathrm{Al}_{6} \mathrm{Si}_{42} \mathrm{O}_{96}$, is equivalent to $\mathrm{NaAlSi}_{7} \mathrm{O}_{16}$, for a $\mathrm{Si}$ :Al mole ratio of 7.0 (Ramachandran et al. 2005). The chemical composition of Zeolon 900 (containing 98\% mordenite)

(a) Delegard CH. 2009. Sample Preparation and Analysis for Determining Uranium Oxide Oxidation States in K Basin Sludges, RPG-CMC-255, Rev. 0. Pacific Northwest National Laboratory, Richland, WA. 
is reported to have the formula $\mathrm{Na}_{2} \mathrm{Al}_{2} \mathrm{Si}_{10} \mathrm{O}_{24}$ for a $\mathrm{Si}: \mathrm{Al}$ mole ratio of $5.0^{(\mathrm{a})}$ while Zeolon $900 \mathrm{H}$ (the hydrogen form of Zeolon 900) is $32.1 \mathrm{wt} \% \mathrm{Si}$ and $6.9 \mathrm{wt} \% \mathrm{Al}$ for the Si:Al mole ratio of $4.5 .^{(\mathrm{b})}$

\subsubsection{Organic lon Exchange Resin}

The organic ion exchange resin (OIER) used in the sludge simulant is Purolite NRW37, a 40:60 (by volume) mixture of strong acid cation (NRW100) and strong base anion (NRW400) resin. This is the same resin that was used to control water quality in the K Basins. ${ }^{(\mathrm{c})}$

\subsubsection{Flocculating Agent}

Optimer 7194 Plus flocculating agent was used during K East (KE) Basin sludge consolidation operations and, on a more limited scale, on the KE and KW sludge transfer operations. The Optimer 7194 Plus flocculating agent used in preparing the simulant was obtained from the Nalco distributor as a concentrate. A $0.5-\mathrm{wt} \%$ dispersion in water of the Optimer agent was prepared, and the diluted Optimer was introduced, where called for, to the water-suspended sludge solids according to manufacturer's recommendations and in concentrations corresponding to the cumulative values added to K Basin sludge.

\subsection{Experimental Methods and Apparatus}

The preparation of the simulated sludges and the design and use of the experimental apparatus are described in this section. Details on experimental measurements, including measurement of shear strength, also are presented.

\subsection{1 $\mathrm{UO}_{2}$ Preparation}

The $\mathrm{UO}_{2}$ slurry used in testing was taken from the stock supplied by Manufacturing Sciences Corporation that had been prepared from anoxic aqueous corrosion of uranium metal turnings

(a) Hastings TW. 1997. FAX communication to I Papp, May 19, 1997, Zeolyst International, Valley Forge, Pennsylvania.

(b) Pool KH, CH Delegard, AJ Schmidt, and KL Silvers. 1998. "Results from Test 1, 'Acid Digestion of Zeolite and Hydrated Iron Oxide in Proportions Representative of Analyzed Sludge Materials'." Letter Report 2851004 to Duke Engineering \& Services, Hanford. January 1998, Pacific Northwest National Laboratory, Richland, Washington.

(c) The OIER used in the K Basins, mixed bed cation/anion resin Purolite NRW37, is composed of 60 vol\% anion resin NRW400 and 40 vol\% NRW100 cation resin (Purolite 2007). These resins were designed to withstand high radiation doses for power reactor water decontamination. Therefore, ion exchange capacity loss due to radiolytic or chemical degradation is unlikely. However, some ion exchange capacity for OIER in the containerized sludge present in the KW Basin likely is occupied by calcium, sodium, and carbonate (and chemically trace radionuclides such as cesium-137 and strontium-90) from previous treatment of the K Basin waters and subsequent exposure.

Vendor specifications show that the anion exchange capacity of pure NRW400 resin is $1.0 \mathrm{eq} / \mathrm{L}$ on a wet volume basis (Purolite 2007). Because NRW400 is $60 \mathrm{vol} \%$ of the NRW37 mixed bed resin used in the $\mathrm{K}$ Basins, the anion uptake capacity of pure mixed resin is $0.6 \mathrm{eq} / \mathrm{L}$. 
(i.e., conditions similar to those under which the $\mathrm{UO}_{2}$ in $\mathrm{K}$ Basin sludge was formed; see Section 2.1.1). No further material preparation was performed.

Each of the six $\mathrm{UO}_{2}$ test items prepared under TI 53451-TI20 began on 21 September 2009 with weighed quantities of $\mathrm{UO}_{2}$ solids slurry in $\mathrm{DI}$ water placed in graduated $15-\mathrm{mL}$ glass centrifuge cones having tapered bottoms. A layer of fine solids was visually observed to settle last. In each test, the $\mathrm{UO}_{2}$ solids settled to $\sim 2.7 \mathrm{~mL}$ volume ( $\sim 3.2 \mathrm{~cm}$ deep), all within the sharply tapering bottom of the cone, which ends at about $3 \mathrm{~mL}$. An 3-mL overlayer of DI water was kept to make sure of solids saturation. Cones with tapered bottoms were used to allow the settled uranium oxide solids to swell upwards, if solids expansion should occur, rather than be compressed laterally. The $\mathrm{UO}_{2}$ solids were stored in this fashion with solid plastic caps to minimize contact with atmospheric oxygen until needed for the oxidation testing.

\subsubsection{KW Containerized Simulant Sludge Preparation}

The KW simulated containerized sludge components were $\mathrm{UO}_{2}, \mathrm{UO}_{3} \cdot 2 \mathrm{H}_{2} \mathrm{O}$, ferrihydrite, gibbsite, ALE sand, Purolite NRW37 OIER, mordenite inorganic ion exchanger, and water. Optimer 7194 Plus flocculating agent was added to some experiments. The simulated KW containerized sludge composition used in testing, shown in Table 2.1, was derived from the composition of a physical/chemical simulant (Burbank 2009). The sludge component quantities required to prepare the 2.277-g (dry basis) portions used in each KW containerized sludge test are shown in the right-most column. Note that the amounts of ion exchange media used in previous formulations of this simulated sludge (e.g., as used in Sinkov et al. 2010) were lower. The OIER content increased to $7.5 \mathrm{wt} \%$ from the $2.0 \mathrm{wt} \%$ used in previous testing, the mordenite increased to $7.7 \mathrm{wt} \%$ from $2.0 \%$, and ALE sand correspondingly decreased to $16.4 \mathrm{wt} \%$ from the $27.6 \mathrm{wt} \%$ used previously.

To attain uniform composition, the simulated sludge components were prepared from their respective ingredients individually for each test rather than taken as a portion of a larger batch. Sufficient DI water was added to each test to completely moisten the solids and leave a few milliliters of supernatant water in the $15-\mathrm{mL}$ volume-graduated glass centrifuge cones used as test vessels. The test vessels were tightly capped until needed for testing. Each of the seven KW containerized sludge simulant tests contained from 4.80 to $5.60 \mathrm{~mL}$ of settled solids.

Two larger portions of KW containerized sludge simulant were prepared for offsite vendor experiments. Before the materials were dispatched, shear-strength measurements were made of these duplicate samples. The Optimer 7194 Plus flocculating agent was added in proportions shown in Table 2.1 to each simulant batch.

\subsubsection{Apparatus}

Two types of sludge aging experiments were performed. In the Flowing Oxygen tests, 99.99\% pure humidified oxygen gas flowed into the gas space of the settled $\mathrm{UO}_{2}$ and $\mathrm{KW}$ containerized sludge simulant slurries while the test items were held at $51^{\circ} \mathrm{C}$ for times up to 287 days for the $\mathrm{UO}_{2}$ tests and up to 106 days for the KW containerized sludge simulant. In the Static Air tests, 50:50 mole basis $\mathrm{UO}_{2}: \mathrm{UO}_{3} \cdot 2 \mathrm{H}_{2} \mathrm{O}$ mixtures and $\mathrm{KW}$ containerized sludge simulant (composition shown in Table 2.1) were held, as slurries, in loosely capped vessels at $96^{\circ} \mathrm{C}$ for 96 hours under non-purged conditions. 
Table 2.1. KW Containerized Simulant Sludge Basis and Composition

\begin{tabular}{|c|c|c|c|c|c|c|}
\hline \multicolumn{2}{|c|}{$\begin{array}{l}\text { KW Basin Container Simulant - } \\
\text { Physical/Chemical Dry Basis } \\
\text { (Burbank 2009) }\end{array}$} & \multicolumn{3}{|c|}{$\begin{array}{l}\text { Uranium, OIER, and } \\
\text { Mordenite Components Added }\end{array}$} & \multicolumn{2}{|c|}{$\begin{array}{l}\text { Component Quantities to } \\
\text { Prepare } 2.277 \mathrm{~g} \text { (dry solids) of } \\
\text { Sludge Simulant }\end{array}$} \\
\hline Material & Amt., wt $\%$ & Material & Amt., wt $\%$ & Amt., g/mL & Material & Amt., g \\
\hline $\mathrm{FeOOH}$ or $\mathrm{Fe}(\mathrm{OH})_{3}$ & 21.9 & errihydrite & 21.9 & 0.186 & Ferrihydrite & \\
\hline $\mathrm{Al}(\mathrm{OH})_{3}$ & 7.8 & & & & $1(\mathrm{OH})_{3}$ & \\
\hline Sand & 4.7 & LE sand ${ }^{(a)}$ & 16.4 & 0.139 & ALE sand & 0.388 \\
\hline \multirow[t]{2}{*}{ Aggregate } & \multirow[t]{2}{*}{16.9} & OIER $^{(b)}$ & 7.5 & .064 & OIER & 0.177 \\
\hline & & Mordenite $^{(\mathrm{c})}$ & 7.7 & 066 & Mordenite & 0.182 \\
\hline $\mathrm{CeO}_{2}$ or equiv. & 30.9 & $\mathrm{UO}_{2}{ }^{(\mathrm{d})}$ & 16.0 & 0.136 & Wet 50 & \\
\hline Steel grit or equiv. & 4.2 & $\mathrm{UO}_{3} \cdot 2 \mathrm{H}_{2} \mathrm{O}^{(\mathrm{d})}$ & 19.1 & 0.162 & $\begin{array}{l}\mathrm{UO}_{3} \cdot 2 \mathrm{H}_{2} \mathrm{O}(0.829 \mathrm{~g} \\
\text { dry oxides; } 0.667 \mathrm{~g} \mathrm{U})\end{array}$ & $\mathrm{TBD}^{(\mathrm{d})}$ \\
\hline ense metal or alloy & 3.6 & U metal & 3.6 & 506 & U metal & none \\
\hline \multirow{2}{*}{\multicolumn{6}{|c|}{\begin{tabular}{c|c|r|}
100.0 & 0.851 & Total dry weight \\
Flocculating agent $-0.5 \mathrm{wt} \%$ Optimer 7194 Plus
\end{tabular}}} & 2.277 \\
\hline & & & & & & none $^{(\mathrm{f})}$ \\
\hline \multicolumn{7}{|c|}{$\begin{array}{l}\text { b) The relative OIER amount corresponds to the amount in KE Basin sludge }\left(1.05 \mathrm{~m}^{3} \text { OIER } / 18.4 \mathrm{~m}^{3} \text { total sludge) based on the }\right. \\
\text { density of OIER (Purolite 2007) and the assumptions that the OIER ratio in KW Basin sludge is the same as that in KE } \\
\text { Basin sludge, and the volume fractions of water in the settled OIER and settled sludge are equal. }\end{array}$} \\
\hline \multicolumn{7}{|c|}{$\begin{array}{l}\text { The relative mordenite amount is based on the amount in KE Basin sludge }\left(20 \mathrm{ft}^{3} \text {, or } 0.566 \mathrm{~m}^{3} \text {, of mordenite in } 18.4 \mathrm{~m}^{3} \text { total }\right. \\
\text { sludge), the assumption that the mordenite ratio in KW Basin sludge is the same as that in KE Basin sludge, and the } \\
\text { assumption that the volume fractions of water in the settled mordenite and settled sludge are equal. }\end{array}$} \\
\hline \multicolumn{7}{|c|}{$\begin{array}{l}\text { The } \mathrm{UO}_{2} \text { and } \mathrm{UO}_{3} \cdot 2 \mathrm{H}_{2} \mathrm{O} \text { combined weights correspond to the sum of } \mathrm{CeO}_{2} \text { (or equivalent) and steel grit (or equivalent) } \\
\text { weights where } \mathrm{CeO}_{2} \text { and steel grit are physical representations of particulate and agglomerated uranium oxide, respectively. } \\
\text { The } \mathrm{UO}_{2}: \mathrm{UO}_{3} \cdot 2 \mathrm{H}_{2} \mathrm{O} \text { is } 50: 50 \text { mole\% } \mathrm{U}(\mathrm{IV}) \text { and } \mathrm{U}(\mathrm{VI}) \text { prepared as an aqueous paste with total weight and amount of } \\
\text { contained water to be determined (TBD) based on analyses of the paste. }\end{array}$} \\
\hline \multicolumn{7}{|c|}{$\begin{array}{l}\text { A } 0.5 \mathrm{wt} \% \text { dispersion of Optimer } 7194 \text { Plus flocculant was used in the simulant prepared for shear-strength testing under TI } \\
53451-\mathrm{TI} 21 \text {. However, a joint decision was made by the PNNL project manager and the CHPRC buyer's technical } \\
\text { representative (BTR) to omit it from the heated agglomeration studies conducted under TIs 53451-TI24, Rev. 1, and 53451- } \\
\text { TI24, Rev. 1, Addendum, because the floc agent would make the sludge/water interface level difficult to determine because } \\
\text { of the agglomeration (lumpiness) created. }\end{array}$} \\
\hline
\end{tabular}

\subsubsection{Flowing Oxygen at $51^{\circ} \mathrm{C}$}

The oxidation testing was performed by flowing humidified pure oxygen over the heated test items. Each test item was capped, and each cap had two holes that were fitted with $\sim 1$-mm plastic tubing that entered and exited to allow gas flow in series through as many as six cones. Oxygen gas humidified at room temperature was supplied to the first cone at low flow rates (approximately $1 \mathrm{~mL} /$ minute) in the series with the tubing arranged to conduct the gas downstream to the successive cones. The oxygen gas supply was humidified by being passed through two gas water bubblers before reaching the first cone. The gas stream exiting the final cone was conducted to a small beaker filled with water. Bubbles in the beaker indicated that the gas flow was maintained. This arrangement allowed water-saturated pure oxygen gas to be present in each cone. The test items were held at $51^{\circ} \mathrm{C}$ by placing the centrifuge cones in a thermostatted water bath controlled by a calibrated thermocouple. 
The experimentation began with six $\mathrm{UO}_{2}$ items. With time, as $\mathrm{UO}_{2}$ items were removed for analysis, $\mathrm{KW}$ containerized sludge simulant test items were added. A capped centrifuge cone with $\sim 2.5 \mathrm{~mL}$ of settled $\mathrm{UO}_{2}$ and supernatant water but without a humidified oxygen supply was retained as a control. A stock of KW containerized sludge simulant also was kept at room temperature as a control.

\subsubsection{Static Air at $96^{\circ} \mathrm{C}$}

In separate tests, two $\mathrm{UO}_{2} / \mathrm{UO}_{3} \cdot 2 \mathrm{H}_{2} \mathrm{O}$ samples (Samples U-1 and U-2) and two KW containerized simulant sludge samples (Samples S-5 and S-6) were given a warm-water treatment under static air conditions. The samples were heated to $96^{\circ} \mathrm{C}$ using a thermostatted water-bath heat block apparatus controlled by a calibrated thermocouple and held at that temperature for 96 hours. In this system, the 15$\mathrm{mL}$ centrifuge cones were inserted into individual $25-\mathrm{mL}$ vial water jackets, which, in turn, were placed into a heating block. The caps were left loosely tightened, but air exchange was not promoted by imposed gas flow. Two separate $\mathrm{UO}_{2} / \mathrm{UO}_{3} \cdot 2 \mathrm{H}_{2} \mathrm{O}$ samples (Samples U-3 and U-4) and a stock of KW containerized sludge simulant (Sample S-Start) were capped tightly and maintained at room temperature for use as controls.

\subsubsection{Test Matrix}

The materials and experimental test conditions for the aging tests are summarized in Table 2.2. A separate test matrix for shear-strength measurements and results is provided in Section 3.3.

\subsubsection{Analyses}

The volumes of the settled solids in the volume-graduated centrifuge cones were monitored with time. In designing the experiment, it was expected that the oxidation would be greater at the top of the settled solids than at the bottom such that the progress of the reaction would not be uniform through the settled solids bed. This would be the result of diffusion limitations through the settled solids. Because the reaction progress in a particular test cannot be determined without removing and analyzing the settled solids, thus disturbing the solids volume determinations, multiple parallel tests were required. Thus, the individual tests were terminated at various times so that the solids in each item could be homogenized and the extents of conversion of $\mathrm{U}(\mathrm{IV})\left(\right.$ e.g., $\left.\mathrm{UO}_{2}\right)$ to $\mathrm{U}(\mathrm{VI})\left(\right.$ e.g., $\left.\mathrm{UO}_{3} \cdot 2 \mathrm{H}_{2} \mathrm{O}\right)$ could be determined.

The oxidation extents were determined by dissolving portions of the homogenized solids in mixed $\mathrm{H}_{3} \mathrm{PO}_{4} / \mathrm{Na}_{2} \mathrm{SO}_{4}$ solution and analyzing the solution spectra for $\mathrm{U}(\mathrm{IV})$ and $\mathrm{U}(\mathrm{VI})$ concentrations under conditions described previously [Sinkov et al. 2008 and footnote (b) on page 2.2 of the present report]. Visual observations of oxidation were made by noting the depths of color change in the settled solids.

Visual observations of agglomeration were made when the individual tests were terminated for analysis. The strengths of the solids were qualitatively assessed by slump testing, probing with a spatula ( $\sim 6$-g mass; $\sim 14$-cm long; Figure 2.1), by shaking and tapping the centrifuge cones, and by slump testing of the solids as they were tipped in the test vessels from the vertical position. 
Table 2.2. Experimental Test Matrix

\begin{tabular}{|c|c|c|c|c|c|}
\hline Test & Material & $\mathrm{T},{ }^{\circ} \mathrm{C}^{(\mathrm{a})}$ & Start Date & End Date & $\begin{array}{c}\text { Total Time at } \\
\text { Temperature, days }\end{array}$ \\
\hline \multicolumn{6}{|c|}{$\mathrm{UO}_{2}$ and KW Containerized Sludge Simulant at $\sim 51^{\circ} \mathrm{C}$ under Flowing $\mathrm{O}_{2}$ Gas } \\
\hline Control & $\mathrm{UO}_{2}{ }^{(\mathrm{b})(\mathrm{c})}$ & 51.0 & 21 Sept 2009 & 14 July 2010 & 287 \\
\hline 1 & $\mathrm{UO}_{2}^{(\mathrm{c})}$ & 51.0 & 21 Sept 2009 & 22 Oct 2009 & 22 \\
\hline 2 & $\mathrm{UO}_{2}{ }^{(\mathrm{c})}$ & 51.0 & 21 Sept 2009 & 1 Dec 2009 & 62 \\
\hline 3 & $\mathrm{UO}_{2}{ }^{(\mathrm{c})}$ & 51.0 & 21 Sept 2009 & 27 Jan 2010 & 119 \\
\hline 4 & $\mathrm{UO}_{2}{ }^{(\mathrm{c})}$ & 51.0 & 21 Sept 2009 & 25 Mar 2010 & 176 \\
\hline 5 & $\mathrm{UO}_{2}{ }^{(\mathrm{c})}$ & 51.0 & 21 Sept 2009 & 25 Mar 2010 & 176 \\
\hline 6 & $\mathrm{UO}_{2}{ }^{(\mathrm{c})}$ & 51.0 & 21 Sept 2009 & 14 July 2010 & 287 \\
\hline S-control & KW Cont. Sim. ${ }^{(b)}$ & 50.9 & 30 Mar 2010 & 14 July 2010 & 106 \\
\hline S-1 & KW Cont. Sim. & 50.9 & 30 Mar 2010 & 7 June 2010 & 69 \\
\hline S-2 & KW Cont. Sim. & 50.9 & 30 Mar 2010 & 14 July 2010 & 106 \\
\hline S-3 & KW Cont. Sim. & 50.9 & 30 Mar 2010 & 14 July 2010 & 106 \\
\hline S-4 & KW Cont. Sim. & 50.9 & 30 Mar 2010 & 14 July 2010 & 106 \\
\hline \multicolumn{6}{|c|}{$\mathrm{UO}_{2}: \mathrm{UO}_{3} \cdot 2 \mathrm{H}_{2} \mathrm{O}$ and $\mathrm{KW}$ Containerized Sludge Simulant at $\sim 96^{\circ} \mathrm{C}$ under Static Air } \\
\hline $\mathrm{U}-3$ & $\mathrm{UO}_{2}: \mathrm{UO}_{3} \cdot 2 \mathrm{H}_{2} \mathrm{O}$ & $\sim 21$ & & & \\
\hline $\mathrm{U}-4$ & $\mathrm{UO}_{2}: \mathrm{UO}_{3} \cdot 2 \mathrm{H}_{2} \mathrm{O}$ & $\sim 21$ & & & \\
\hline $\mathrm{U}-1$ & $\mathrm{UO}_{2}: \mathrm{UO}_{3} \cdot 2 \mathrm{H}_{2} \mathrm{O}$ & 96.4 & 19 July 2010 & 23 July 2010 & $4(96 \mathrm{~h})$ \\
\hline $\mathrm{U}-2$ & $\mathrm{UO}_{2}: \mathrm{UO}_{3} \cdot 2 \mathrm{H}_{2} \mathrm{O}$ & 96.4 & 19 July 2010 & 23 July 2010 & $4(96 \mathrm{~h})$ \\
\hline S-start & $\begin{array}{l}\text { KW Cont. Sim. } \\
\text { with floc agent }\end{array}$ & $\sim 21$ & & & \\
\hline S-5 & KW Cont. Sim. ${ }^{(\mathrm{d})}$ & 96.4 & 19 July 2010 & 23 July 2010 & $4(96 \mathrm{~h})$ \\
\hline S-6 & KW Cont. Sim. & 96.4 & 19 July 2010 & 23 July 2010 & $4(96 \mathrm{~h})$ \\
\hline \multicolumn{6}{|c|}{$\begin{array}{l}\text { (a) Average temperatures, } \pm 0.9^{\circ} \mathrm{C} \text { or better, } 1 \sigma \text {. } \\
\text { (b) Static air; no gas exchange. } \\
\text { (c) Nine-day total gaps occurred in October } 2009 \text { without oxygenation and heating. } \\
\text { (d) Two days of } \mathrm{O}_{2} \text { exposure at } 50.9^{\circ} \mathrm{C} \text { occurred before } 4 \text { days at } 96^{\circ} \mathrm{C} \text { under static air. }\end{array}$} \\
\hline
\end{tabular}

The $\mathrm{UO}_{2}$ oxidation sample Test 4 was taken for imaging by scanning electron microscopy (SEM). This was performed to determine approximate particle size and morphology for the starting $\mathrm{UO}_{2}$ oxidation test materials. The products of these tests showed the greatest degree of agglomeration and strength increase of any of the $\mathrm{UO}_{2}, \mathrm{UO}_{2}: \mathrm{UO}_{3} \cdot 2 \mathrm{H}_{2} \mathrm{O}$, and $\mathrm{KW}$ containerized sludge simulant materials investigated.

For each test, the settled densities before and after heating were determined by mass and volume measurements, and supernatant samples were collected before and after heating for $\mathrm{pH}$ measurement.

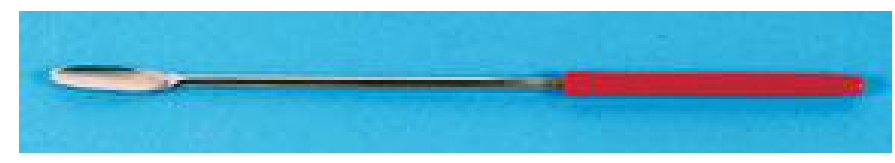

Figure 2.1. Spatula Used to Probe Sludge Solids

Small control material samples (from tests U-3 and S-start) and materials after heating (tests U-1 and S-6) from the $50^{\circ} \mathrm{C}$ tests were analyzed by XRD. This was done by taking wet $\sim 100$ - to 200 -mg samples 
from the selected test items, drying the samples at room temperature in a Drierite (anhydrous calcium sulfate) desiccator, and mounting the samples for analysis. The sample mounting and XRD analyses were conducted according to established procedures. ${ }^{(a)}$ The resulting diffraction scans were interpreted to determine if phase changes, particularly dehydration reactions, occurred because of heating. Because the objective of the XRD analysis was qualitative identification of starting sludge phases and their potential post-heating dehydration phases and because the S-start sample was being retained for settled strength testing, aggressive mixing was not used to obtain most of the XRD samples. In addition, to prevent potential dehydration of metaschoepite, aggressive grinding and crushing were not used in XRD mount preparation. As a result, the XRD samples were only qualitatively representative of the phases present in the entire material but not quantitatively representative.

\subsubsection{Shear-Strength Measurements of Simulated Sludge and Simulated Sludge Components}

Samples of $\mathrm{UO}_{2}$ slurry have been oxidized to form varying relative amounts of $\mathrm{UO}_{3} \cdot 2 \mathrm{H}_{2} \mathrm{O}$ by reaction with pure oxygen gas. This conversion is described in Section 2.1.1. The shear strengths of $\mathrm{UO}_{2} / \mathrm{UO}_{3} \cdot 2 \mathrm{H}_{2} \mathrm{O}$ mixtures at respective mole ratios of $100 \% / 0 \%, 49 \% / 51 \%$, and $35 \% / 65 \%$ and of two identical samples of full KW simulant sludge were measured by vane rheometry. The flocculated KW simulant sludge was prepared based on the composition given in Table 2.1.

The shear strength was measured on simulated sludge samples that had been settled for extended times and then for various times after re-mixing and settling. The measurements were performed with a Haake RV20 Rheometer fitted to an M5 viscometer drive and RC20 controller. The M5 viscometer is capable of evaluating fluid rheological properties using Couette flow devices or shear strength using shear vanes. The M5 measuring head is a "Searle" type viscometer capable of producing rotational speeds up to $500 \mathrm{RPM}$ and measuring torques up to $0.049 \mathrm{~N} \cdot \mathrm{m}$. The minimum rotational speed and torque resolution achievable by this measuring head are $0.05 \mathrm{RPM}$ and $0.00049 \mathrm{~N} \cdot \mathrm{m}$, respectively. In accordance with the applicable procedure, ${ }^{(b)}$ the performance of the torque spring in the M5 viscometer was verified no more than 30 days before and after sample measurements using a viscosity standard traceable to the National Institute of Standards and Technology. Shear-strength measurements were performed under approved Test Instructions 53451-TI22 and 53451-TI30. ${ }^{(\mathrm{c})}$

The procedure ${ }^{(b)}$ outlines geometrical spacing requirements for vane tool and solids containers when testing for shear strength. The shear-vane tools used were either a 4-mm vane radius $\times 16$-mm-high, four-

(a) Scheele RD and CH Delegard. 2005. Preparing Sealed Radioactive Samples for XRD and Other Purposes, RPL-PIP-4, Pacific Northwest National Laboratory, Richland, WA.

Schaef HT. 2004. Operation of Scintag Pad-V X-Ray Diffractometer, RPL-XRD-PIP, Pacific Northwest National Laboratory, Richland, WA.

(b) Daniel RC. 2007. Measurement of Physical and Rheological Properties of Solutions Slurries and Sludges. RPL-COLLOID-02, Rev. 1, Pacific Northwest National Laboratory, Richland, WA.

(c) Delegard, CH. 2010. "Rheological Measurements for Uraninite-Metaschoepite Mixtures", 53451-TI22, Pacific Northwest National Laboratory, Richland, WA.

Burns, CA. 2010. "Rheological Measurements for U-Containing KW Container Sludge Simulant and U Oxide Mixtures”, 53451-TI30, Pacific Northwest National Laboratory, Richland, WA. 
paddle vane that can measure strengths up to $\sim 26,000 \mathrm{~Pa}$ or an 8 -mm vane radius $\times 16$-mm-high, fourpaddle vane that can measure strengths up to $\sim 5,700 \mathrm{~Pa}$. Vane tool selection depended on the expected sample shear strength and sample container geometries. For the current study, closely sequenced shearstrength measurements are not meaningful because the shear strength depends upon sample solid structure, and shear-strength testing disturbs this structure. Therefore, extended times are required after mixing to resettle the solids to the same degree of compaction and structure that existed before mixing.

The 4-mm $\times 16-\mathrm{mm}$ vane tool was employed for initial measurements to accommodate the potential for higher-than-expected shear strengths. The $8-\mathrm{mm} \times 16-\mathrm{mm}$ vane was used on all other shear-strength measurements. 


\subsection{Experimental Results}

The experimental results for the testing of $\mathrm{UO}_{2}$ and $\mathrm{KW}$ containerized sludge simulant under flowing $\mathrm{O}_{2}$ gas at $51^{\circ} \mathrm{C}$ are presented in Section 3.1. The results for testing of $\mathrm{UO}_{2} / \mathrm{UO}_{3} \cdot 2 \mathrm{H}_{2} \mathrm{O}$ samples and KW containerized simulant sludge samples under static gas conditions at $96^{\circ} \mathrm{C}$ are presented in Section 3.2. Results of measurements of the shear strengths of $\mathrm{UO}_{2} / \mathrm{UO}_{3} \cdot 2 \mathrm{H}_{2} \mathrm{O}$ mixtures and of $\mathrm{KW}$ containerized simulant sludge are provided and discussed in Section 3.3.

\section{1 $\mathrm{UO}_{2}$ and $\mathrm{KW}$ Containerized Sludge Simulant at $51^{\circ} \mathrm{C}$ Under Flowing $\mathrm{O}_{2}$ Gas}

Testing was conducted to investigate the behavior of $\mathrm{UO}_{2}$ and simulated $\mathrm{KW}$ containerized sludge aqueous slurries that had been heated under pure oxygen cover gas at nominally $50^{\circ} \mathrm{C}\left(51^{\circ} \mathrm{C}\right.$ was the average temperature). The $\mathrm{UO}_{2}$ behavior is described in Section 3.1.1, and the simulated $\mathrm{KW}$ containerized sludge behavior is described in Section 3.1.2.

\subsubsection{Settled $\mathrm{UO}_{2}$ Slurry Behavior Under Oxygen at $51^{\circ} \mathrm{C}$}

Tests 1 through 3 of the six test items were removed for analysis on 22 October 2009, 1 December 2009 , and 27 January 2010 after 22,62 , and 119 days, respectively, of $51^{\circ} \mathrm{C}$ aqueous exposure to dissolved oxygen in the presence of 1 atmosphere oxygen cover gas (Table 2.2). Tests 4 and 5 were removed from heat on 25 March 2010 after 176 days, and Test 6 was removed on 14 July 2010 after 287 days. Nine days without heat or oxygenation occurred in early October 2009 before termination of Test 1. Each sample was photographed next to the control sample to record visual evidence of oxidation. Physical observations were made of all test items by measuring the volume of the settled solids over the test interval. All test items except Test 6 were probed upon sampling using a small stainless steel spatula (Figure 2.1). The solids for Tests 1, 2, 3, and 5 were stirred thoroughly so that a representative solids sample could be obtained for uranium oxidation-state analysis. Portions of the solids found in Test 4 were sampled for SEM examination. However, because of this asymmetric sampling, analyses of the uranium oxidation state were not performed for Test 4 . Test 6 , which underwent 287 days of $96.4^{\circ} \mathrm{C}$ heating, was not analyzed for oxidation state distribution or by SEM.

The appearances of the centrifuge cones holding settled $\mathrm{UO}_{2}$ solids are shown in Figure 3.1 in the beaker water bath after 3 days of heating and oxygen gas exposure. A layer of darker solids approximately $\sim 1.5 \mathrm{~mm}$ deep is seen at the top of the settled solids for each test. The control test, which was not exposed to oxygen gas flow, also had a dark $\sim 1.5$-mm-deep layer. The darker (black) color marks the progress of initial oxidation from pure dark olive $\mathrm{UO}_{2}$ (see Figure 4.2; Sinkov et al. 2008) and indicates, in part, the incidental oxidation by atmospheric oxygen that occurred in preparing the samples. Results of settled solids volume levels, solids thicknesses, and uranium oxidation state distribution are summarized in Table 3.1. 


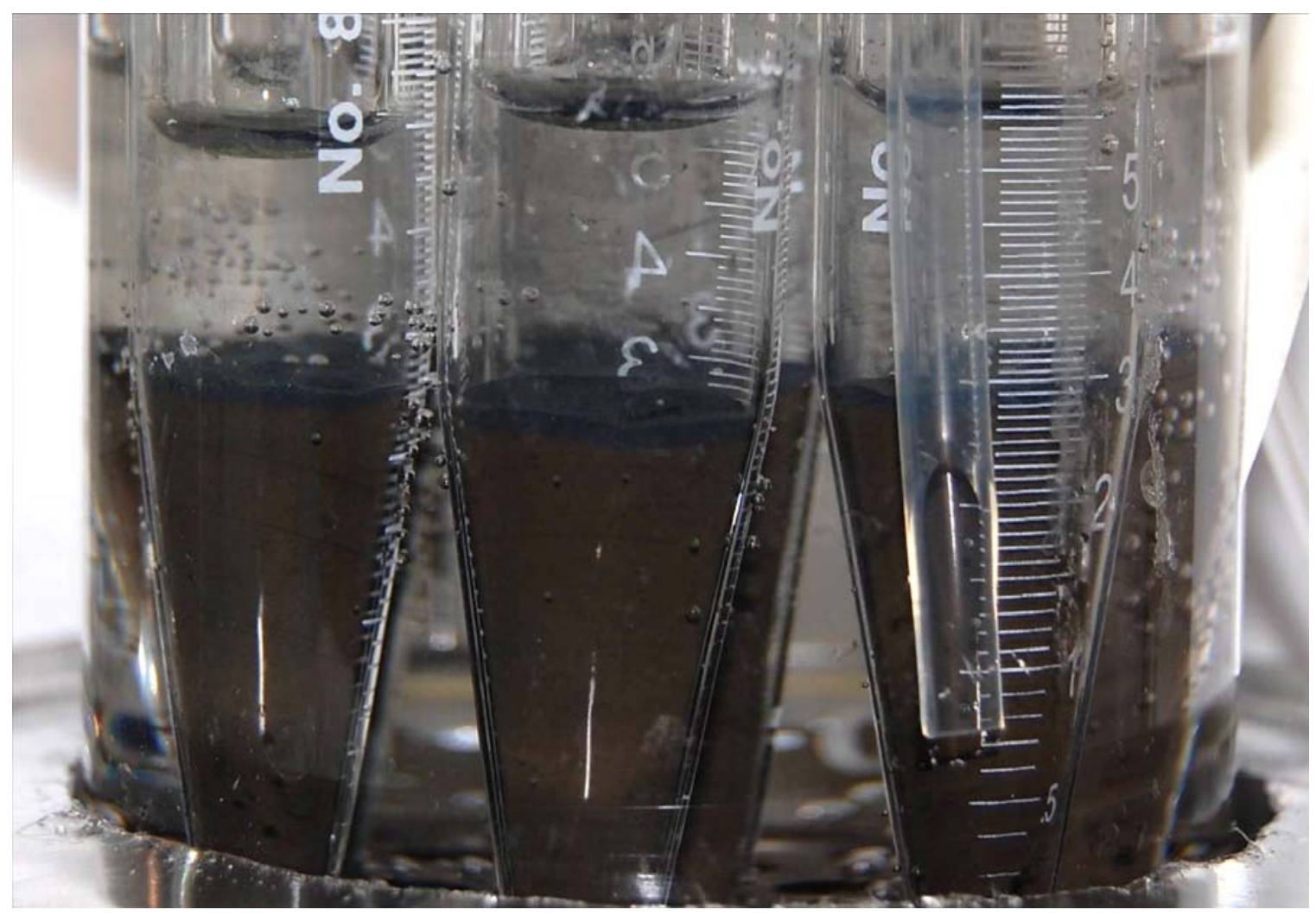

Figure 3.1. Settled $\mathrm{UO}_{2}$ Solids in $51^{\circ} \mathrm{C}$ Water Bath After 3 Days of Oxygen Exposure (black upper layer is $\sim 0.5$ to $1 \mathrm{~mm}$ thick; bubbles are in the water on the outside of the centrifuge cones)

Table 3.1. Settled Volume, Color Change, and Extent of Oxidation for $\mathrm{UO}_{2}$ Solids

\begin{tabular}{|c|c|c|c|c|c|c|c|}
\hline \multirow[b]{2}{*}{ Test ID } & \multirow{2}{*}{$\begin{array}{c}\mathrm{O}_{2} \text { Time, } \\
\text { days }\end{array}$} & \multicolumn{2}{|c|}{ Settled Volume, $\mathrm{mL}$} & \multicolumn{2}{|c|}{ Density, $\mathrm{g} / \mathrm{cm}^{3}$} & \multirow{2}{*}{$\begin{array}{l}\text { Surface Layer } \\
\text { Thickness, mm }\end{array}$} & \multirow[b]{2}{*}{$\% \mathrm{U}(\mathrm{VI})$} \\
\hline & & 7 days & Final & 7 days & Final & & \\
\hline 1 & 22 & 2.75 & 2.75 & 2.13 & 2.09 & $1.65 \mathrm{YG} ; 1.5 \mathrm{~B}^{(\mathrm{a})}$ & 17.7 \\
\hline 2 & 62 & 2.60 & 2.65 & 2.25 & 2.26 & $2.72 \mathrm{YG} ; 1.5 \mathrm{~B}$ & 21.7 \\
\hline 3 & 119 & 2.85 & 2.78 & 2.02 & 1.99 & $3.69 \mathrm{YG} ; 1.5 \mathrm{~B}$ & 26.2 \\
\hline 4 & 176 & 2.95 & 2.95 & 2.01 & 1.97 & $4.29 \mathrm{YG} ; 1.5 \mathrm{~B}$ & NA \\
\hline 5 & 176 & 2.80 & 2.75 & 2.09 & 2.08 & NA & 32.9 \\
\hline 6 & 287 & 2.60 & 2.60 & 2.19 & \multirow{2}{*}{$\begin{array}{l}\text { Not } \\
\text { det'd. }\end{array}$} & $5.32 \mathrm{YG} ; 1.5 \mathrm{~B}$ & NA \\
\hline Control & 0 & 2.65 & 2.60 & 2.15 & & $1.5 \mathrm{~B}$ & 9.6 \\
\hline \multicolumn{4}{|c|}{$\begin{array}{r}\text { Average } \\
\text { Standard deviation, } \pm 1 \sigma\end{array}$} & $\begin{array}{c}2.12 \\
\pm 0.09\end{array}$ & & & \\
\hline
\end{tabular}

The slurry settled to a stable settled volume within a few hours of addition to the centrifuge cones at the onset of testing. Importantly, no discernable regular increase or decrease in solids volume occurred between 7 days and the final observations at 287 days for either the oxygenated tests or the nonoxygenated control. 
In the following sections, 1) more detailed observations are presented (Section 3.1.1.1), 2) the $\mathrm{UO}_{2}$ oxidation rate as discerned by the visual observations is discussed (Section 3.1.1.2), 3) the uranium oxidation states of the individual tests are described (Section 3.1.1.3), 4) SEM results are presented (Section 3.1.1.4), 5) strength observations are presented (Section 3.1.1.5), and 6) the visual observations are compared with Liesegang banding phenomena (Section 3.1.1.6).

\subsubsection{Visual Observations}

The visual appearances of the test items removed after 22, 62, 119, 176, and 287 days of exposure to oxygen-equilibrated $51{ }^{\circ} \mathrm{C}$ water, shown in Figure 3.2 through Figure 3.6, respectively, are compared with the appearances of the control test that was run in a parallel heated manner but without continued oxygen exposure. Visible layering is observed for all test items, including the control item. The yellow-green color indicates metaschoepite while the underlying dark olive color is characteristic of $\mathrm{UO}_{2}$. The upper surface of the 287-day test item exposed to oxygenated water is shown in Figure 3.7.

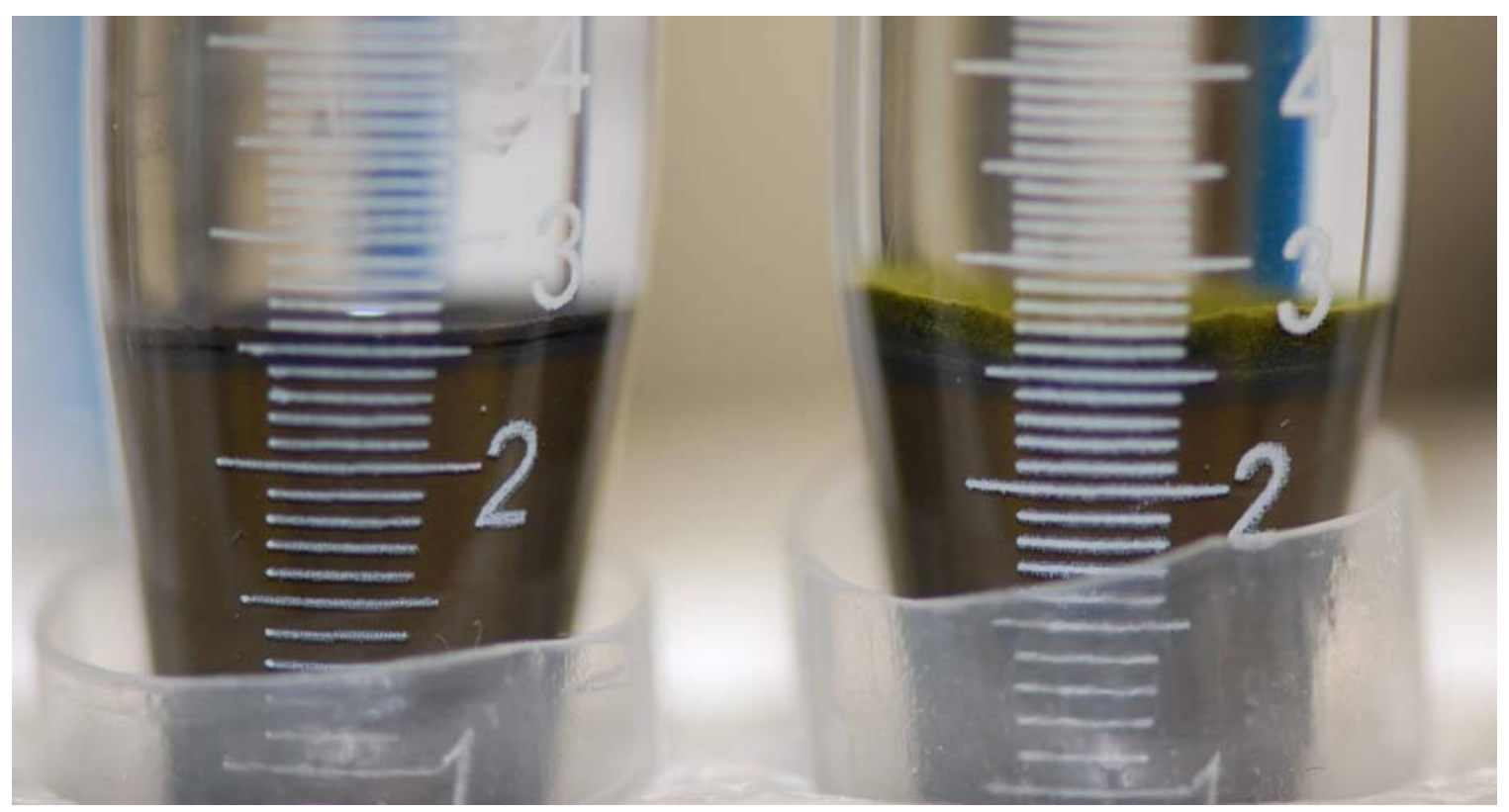

Figure 3.2. Appearance on 22 October 2009 After 22 days Left: Control starting $\mathrm{UO}_{2}$ settled slurry, not exposed to oxygenated water Right: Test $1 \mathrm{UO}_{2}$ slurry after 31 days of oxygenated water exposure 


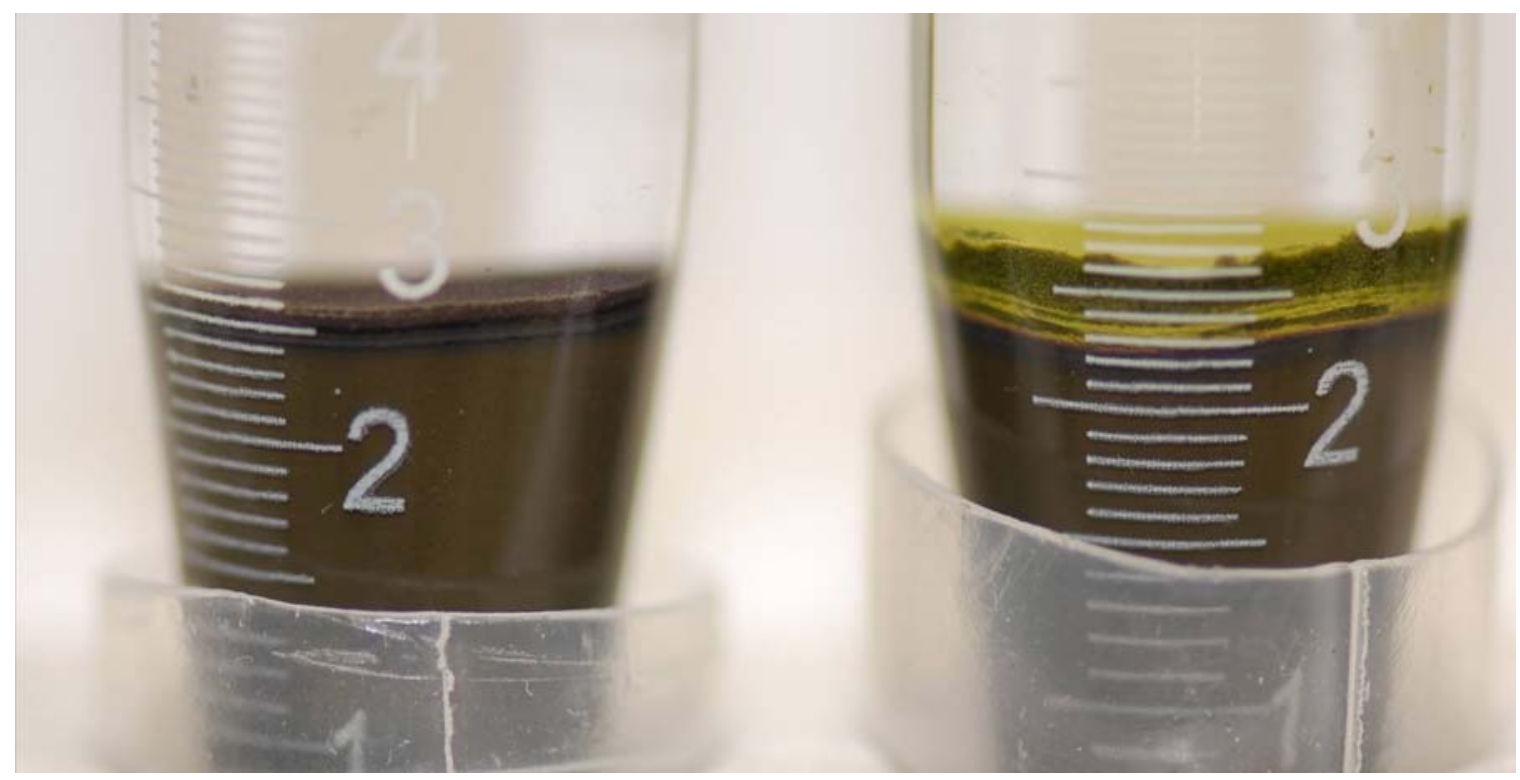

Figure 3.3. Appearance on 1 December 2009 after 62 Days Left: Control starting $\mathrm{UO}_{2}$ settled slurry, not exposed to oxygenated water Right: Test $2 \mathrm{UO}_{2}$ slurry after 71 days of oxygenated water exposure

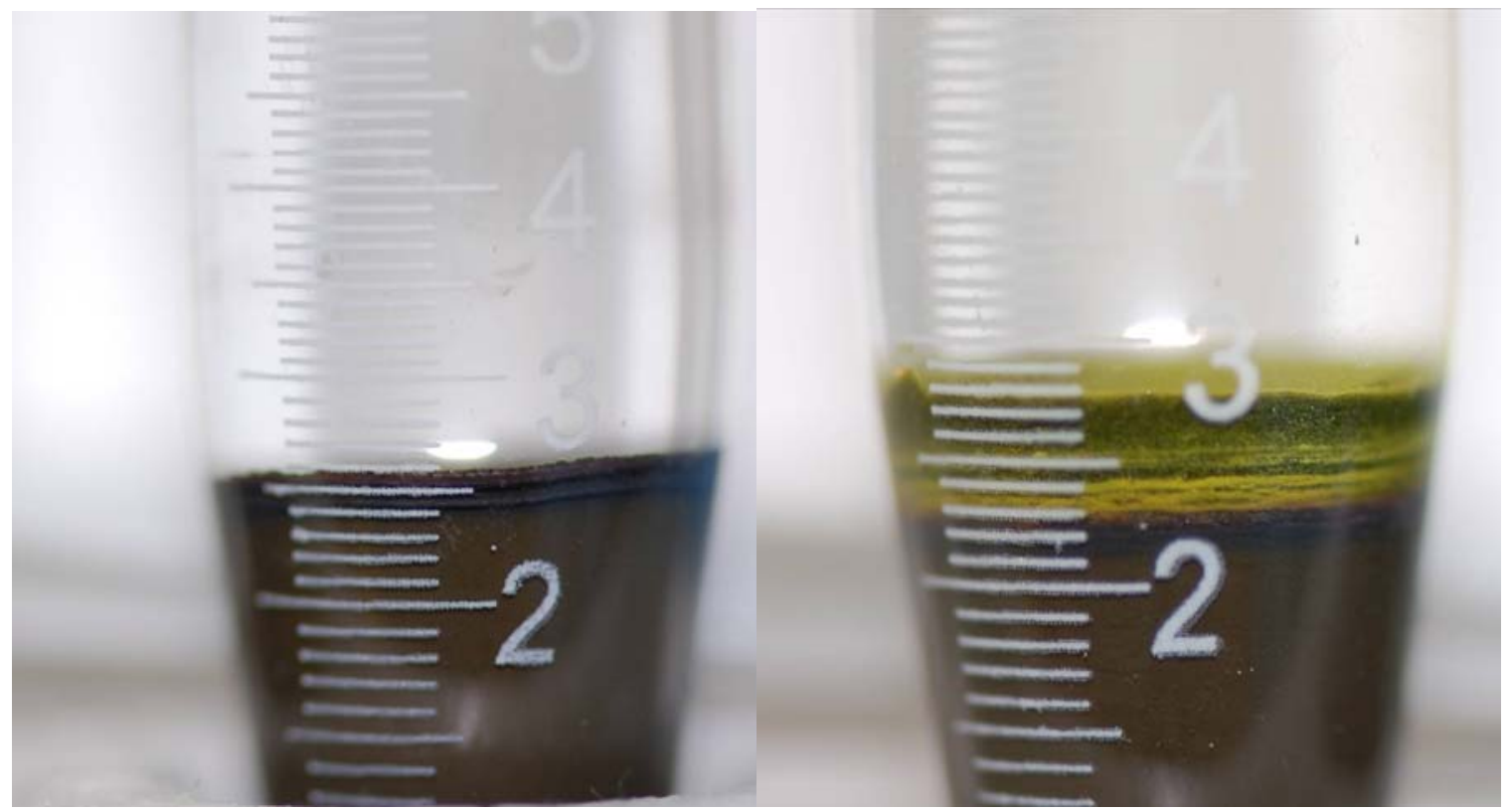

Figure 3.4. Appearance on 27 January 2010 After 119 Days Left: Control starting $\mathrm{UO}_{2}$ settled slurry, not exposed to oxygenated water Right: Test $3 \mathrm{UO}_{2}$ slurry after 128 days of oxygenated water exposure 


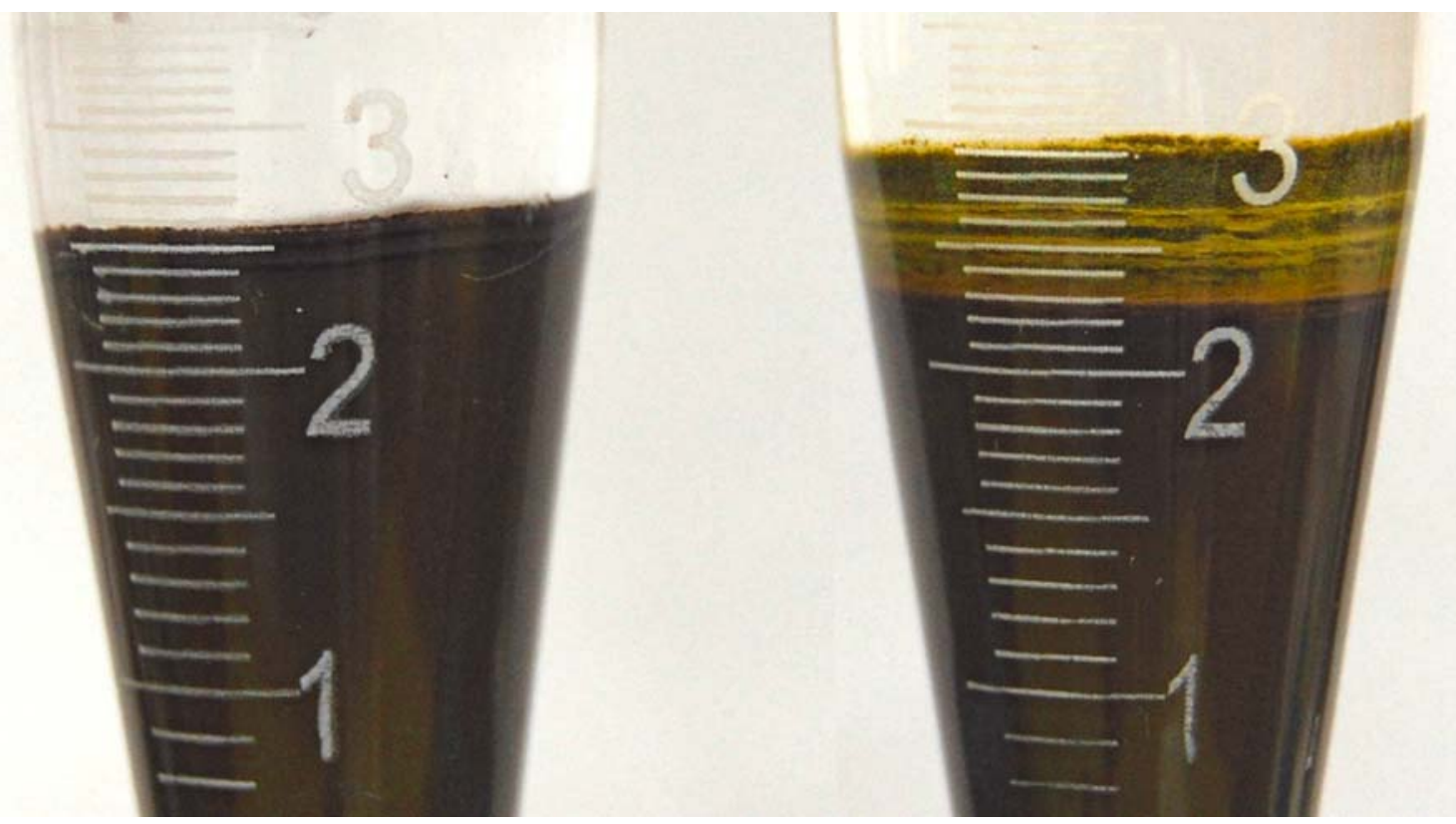

Figure 3.5. Appearance on 25 March 2010 After 176 Days Left: Control starting $\mathrm{UO}_{2}$ settled slurry, not exposed to oxygenated water Right: Test $4 \mathrm{UO}_{2}$ slurry after 185 days of oxygenated water exposure

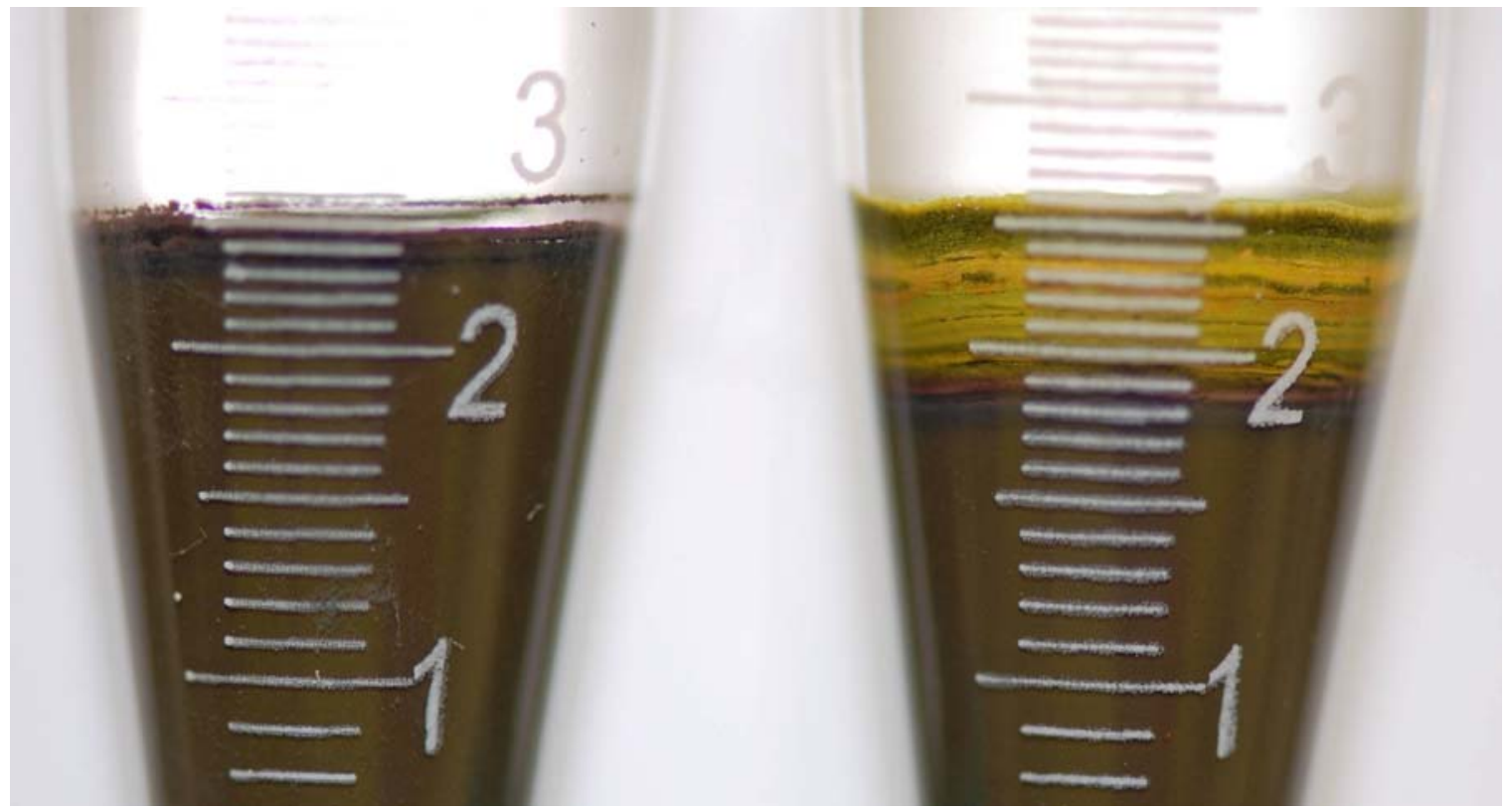

Figure 3.6. Appearance on 14 July 2010 After 287 Days Left: Control starting $\mathrm{UO}_{2}$ settled slurry, not exposed to oxygenated water Right: Test $6 \mathrm{UO}_{2}$ slurry after 287 days of oxygenated water exposure 


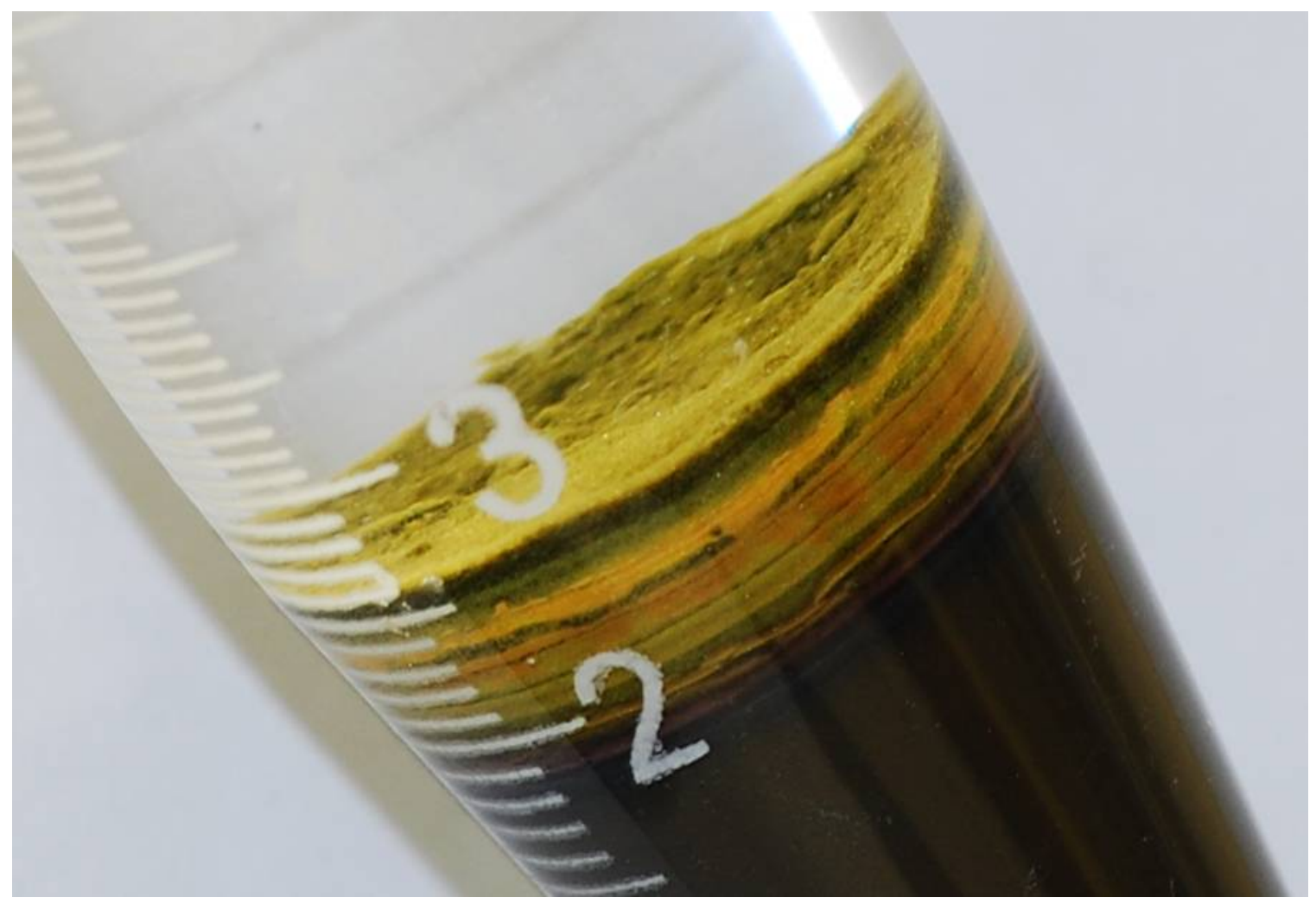

Figure 3.7. Test 6 Side/Upper View on 14 July 2010 After 287 Days of Oxygenated Water Exposure. Sample tilted to the left about $35^{\circ}$ from vertical.

In the control test shown on the left in Figure 3.2 through Figure 3.6, the bulk of the settled solids is a deep olive color. The top layer, about $1.5 \mathrm{~mm}$ thick and dark grey but with a black band in the middle, would include those solids that settled most slowly when added to the cone. These solids may be the $\mathrm{UO}_{2}$ particles or agglomerates having the smallest diameters and settling last. More likely, the difference in color within the top grey layer in the control sample indicates that conversion of some of the $\mathrm{UO}_{2}$ to $\mathrm{UO}_{3} \cdot 2 \mathrm{H}_{2} \mathrm{O}$ occurred by the incidental air exposure during addition to the centrifuge cone and by the consumption of the oxygen present in the contained gas space. Previous studies by Sinkov and colleagues (2008) showed that about $10 \%$ of the initially nearly pure $\mathrm{UO}_{2}$ was oxidized to the hexavalent state (i.e., $\mathrm{UO}_{3} \cdot 2 \mathrm{H}_{2} \mathrm{O}$ ) within 3 to 4 minutes by mixing with water and its contained dissolved oxygen. This occurred because of the small $\mathrm{UO}_{2}$ particle size and the corresponding high specific surface area. The banding in the control sample after 62 days is more evident than the banding seen at 22 days, but, overall, the control sample appearances after 22, 62,119, 176, and 287 days are similar to each other and to the test items after 3 days of $51^{\circ} \mathrm{C}$ exposure to oxygen gas (Figure 3.1), indicating effective isolation from outside air.

The test items at 3 days show a thin, dark grey, upper layer with the remaining solids a deep olive color. The underlying deep olive color persisted over the duration of testing. However, no intermediate black band was seen in the test items after 3 days (Figure 3.1) as were shown in the control test images (Figure 3.2 through Figure 3.6).

Distinct yellow-green layers are observed in all of the oxygenated samples (Figure 3.8). The layer structure becomes thicker and more detailed with reaction time. As shown in Table 3.1, the yellow-green 
layer is $\sim 1.7 \mathrm{~mm}$ thick in the 22-day sample, $\sim 2.7 \mathrm{~mm}$ thick in the 62-day sample, $\sim 3.7 \mathrm{~mm}$ thick in the 119-day sample, $\sim 4.3 \mathrm{~mm}$ in the 176-day sample, and $\sim 5.3 \mathrm{~mm}$ in the 287 -day sample. Whereas the yellow-green solids seem uniform in the 22-day sample, at least five alternating layers of green-yellowgreen-yellow-green are observed within the 62-day solids. The yellow-green banding is also present in the 119-, 176-, and 287-day samples and, like the 62-day sample, the alternating layers are more evident at the lower side of the yellow-green region. A dark-brown to red-brown band about $0.7 \mathrm{~mm}$ thick lies beneath the last yellow-green band in all tests. The dark olive color observed in the remainder of the settled material is similar to that of the starting material and to that of the control. The parallel progression of color development in the upper layers of settled solids was observed throughout testing.
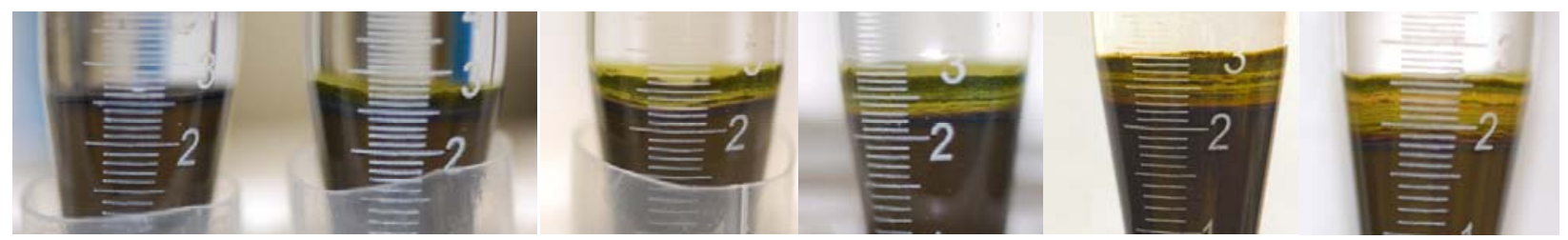

Figure 3.8. Appearances of $\mathrm{UO}_{2}$ Aqueous Slurries Being Oxidized by Dissolved Oxygen Left to right: Control (no $\mathrm{O}_{2}$ ), and after $22,62,119,176$, and 287 days of $51^{\circ} \mathrm{C}$ oxygenated water

The colors in the banding might indicate varying degrees of uranium oxide oxidation with the yellow indicating complete conversion to $\mathrm{UO}_{3} \cdot 2 \mathrm{H}_{2} \mathrm{O}$, which is known to be bright yellow. However, the green color also indicates nearly complete conversion to $\mathrm{UO}_{3} \cdot 2 \mathrm{H}_{2} \mathrm{O}$ as the color is similar to the green observed at the end of previous oxidation tests of $\mathrm{UO}_{2}$ when conversion to $\mathrm{U}(\mathrm{VI})$, as $\mathrm{UO}_{3} \cdot 2 \mathrm{H}_{2} \mathrm{O}$, was virtually complete (Sinkov et al. 2008). A well-rinsed sample of the upper crust material contained uranium that was $\sim 99 \% \mathrm{U}(\mathrm{VI})$. Thus, it is likely that the differences in $\mathrm{UO}_{3} \cdot 2 \mathrm{H}_{2} \mathrm{O}$ product color indicate differing solids particle size with the green-colored material having a larger size.

This is evident in the light reflected from particle facets in the upper layer of green solids and during manipulation of the solids in which the upper layer is found to be coarsely particulate. The first 1 to $2 \mathrm{~mm}$ of depth is composed of loose particles that are readily suspended in water but which also settle quickly. The growth of smaller precipitating particles to form larger particles of the same composition is called Ostwald ripening and can be a participating mechanism for solids agglomeration in sludge. Further examination of particle size and solids intergrowth was done during SEM examinations of the 185-day oxidation product.

In addition to the settled-solids layering, yellow solids were observed to be floating at the wateroxygen interface of the 62- and 119-day tests. The 176-day tests were not examined, and the 287-day test had no floating solids. Floating solids also were not found in the 22-day test. Similar but more conspicuous observations of floating solids have been made in tests done at PNNL of non-irradiated $\mathrm{UO}_{2}$ particles that were left under aerated water cover (Buck et al. 2004). In those tests, the $\mathrm{UO}_{2}$ originally prepared as reactor fuel pellets had first been crushed, sieved to 44 - to $105-\mu \mathrm{m}$ particle size, washed to remove fines, and the granules fired under reducing conditions to restore the 2:1 oxygen:uranium stoichiometry of $\mathrm{UO}_{2}$. Highly hydrophobic floating sub-micron solids appeared overnight. The solids were associated with bubbles and were found by XRD to be metaschoepite. 


\subsubsection{Uraninite Oxidation Rates}

The oxidation of the uraninite $\left(\mathrm{UO}_{2}\right)$ by dissolved oxygen to form $\mathrm{UO}_{3} \cdot 2 \mathrm{H}_{2} \mathrm{O}$ obviously begins at the top of the settled solids layer. The rate of continued oxidation is controlled by the rate of dissolvedoxygen diffusion through the growing depth of the $\mathrm{UO}_{3} \cdot 2 \mathrm{H}_{2} \mathrm{O}$ product layer. If the oxidation rate is controlled by oxygen diffusion, the oxidation depth should be proportional to time ${ }^{1 / 2}$, i.e., the oxidation should follow parabolic kinetics. Based on the data presented in Table 3.1, it is seen that the $\mathrm{UO}_{2}$ oxidation, as manifest by the increase in the depth of the oxidized yellow-green layer, does indeed follow parabolic kinetics $\left(\mathrm{R}^{2}=0.996\right.$; Figure 3.9). The observed oxidation rate law for settled $\mathrm{UO}_{2}$ in $51^{\circ} \mathrm{C}$ water in equilibrium with 1 atm pure oxygen pressure, as derived from Figure 3.9, is shown in Equation 3.1:

$\mathrm{UO}_{2}$ oxidation rate: $51^{\circ} \mathrm{C}$ water, $1 \mathrm{~atm} \mathrm{O}_{2}$

$$
\text { Oxidation depth, } \mathrm{mm}=0.325 \times(\text { time }, \text { days })^{0.5}
$$

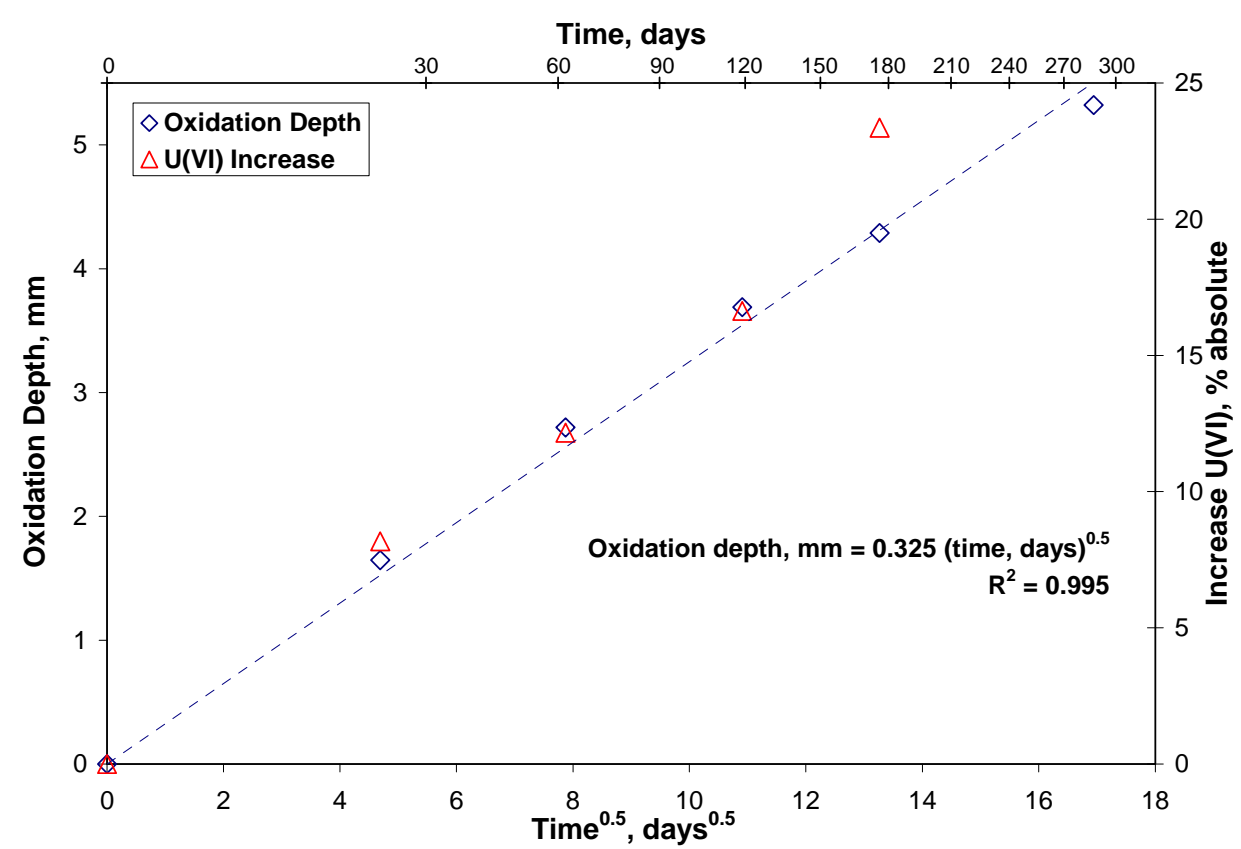

Figure 3.9. Settled $\mathrm{UO}_{2}$ Solids Oxidation to $\mathrm{UO}_{3} \cdot 2 \mathrm{H}_{2} \mathrm{O}$ as Measured by Oxidation Depth with Respect to the Square Root of Time

It is seen in Figure 3.9 that the visually observed oxidation depth and the increase in the U(VI) amount in the blended test material approximately track each other. The $\mathrm{UO}_{2}$ oxidation rate in cooler $\mathrm{K}$ Basin waters is expected to be lower than observed in the testing with $51{ }^{\circ} \mathrm{C}$ pure oxygen-saturated water because of the Basin water's lower temperature and the lower partial pressure of oxygen in air $(\sim 0.2095 \mathrm{~atm})$. The diffusion rate of dissolved oxygen through the metaschoepite bed also should decrease with decreasing temperature. However, the overall expected rate decrease would be tempered by the increased solubility of oxygen in water at lower temperature.

It is known that the $\mathrm{UO}_{2}$ oxidation rate is first order with respect to dissolved oxygen concentration. That is, the rate is directly proportional to the dissolved oxygen concentration (Shoesmith 2000; Shoesmith and Sunder 1991; Grandstaff 1976). The solubility of oxygen in water increases with 
decreasing temperature and follows Henry's Law, meaning that the concentration of oxygen in water is proportional to its partial pressure in the gas phase. For example, based on fits of handbook values (Perry et al. 1984), the $\mathrm{O}_{2}$ concentration in water equilibrated with 1 atm oxygen at $51^{\circ} \mathrm{C}$ is $9.25 \times 10^{-4} \mathrm{M}$ and is $1.38 \times 10^{-3} \mathrm{M}$ at $20^{\circ} \mathrm{C}$. As a result, the rate decrease factor due to the decreased dissolved $\mathrm{O}_{2}$ concentration in $20^{\circ} \mathrm{C}$ aerated water compared with the $51^{\circ} \mathrm{C}$ tests of pure oxygenated water is $0.2095 \times(0.00138 / 0.000925)=0.313$.

Of secondary importance, the carbon dioxide $\left(\mathrm{CO}_{2}\right)$ present in air also would increase the $\mathrm{UO}_{2}$ oxidation rate marginally by dissolving some of the product U(VI) as carbonate complexes (Shoesmith 2000). The $\mathrm{CO}_{2}$ present in air is insufficient to convert the product metaschoepite to rutherfordine, $\mathrm{UO}_{2} \mathrm{CO}_{3}$ (Finch and Murakami 1999). Because of these small or non-existent effects, the influence of atmospheric $\mathrm{CO}_{2}$ on $\mathrm{UO}_{2}$ oxidation and subsequent reactions are neglected in the present discussion.

The oxidation rate decreases with decreased temperature according to the Arrhenius equation. The activation energy $\left(\mathrm{E}_{\mathrm{a}}\right)$ for oxidation of $\mathrm{UO}_{2}$ by dissolved oxygen in non-complexing aqueous solution is 29 to $34 \mathrm{~kJ} / \mathrm{mole}$ (Shoesmith 2000). Assuming that $\mathrm{E}_{\mathrm{a}}=32 \mathrm{~kJ} / \mathrm{mole}$, the rate decrease factor caused by lowering the temperature from $51^{\circ} \mathrm{C}$ to $20^{\circ} \mathrm{C}$ would be 0.285 as shown in Equation 3.2:

$$
\frac{\text { rate }_{20^{\circ} \mathrm{C}}}{\text { rate }_{51^{\circ} \mathrm{C}}}=\mathrm{e}^{\frac{\mathrm{E}_{\mathrm{a}}}{\mathrm{R}}\left(\frac{1}{\mathrm{~T}_{51^{\circ} \mathrm{C}}}-\frac{1}{\mathrm{~T}_{20^{\circ} \mathrm{C}}}\right)}=\mathrm{e}^{\frac{32000 \mathrm{~J} / \mathrm{mole}}{8.3145 \mathrm{~J} / \mathrm{mole}-\mathrm{deg}}\left(\frac{1}{324.15}-\frac{1}{293.15}\right)}=0.285
$$

However, from previous experiments, it is known that the reaction of finely particulate (subnanometer) $\mathrm{UO}_{2}$ with well-stirred oxygenated water is rapid, occurring in minutes at room temperature, while about $90 \%$ of all particles oxidize in 20 days (Sinkov et al. 2008). Due to the linear dependence of oxygen concentration, the same oxidation extent would require $\sim 100$ days in aerated water. Therefore, over time periods measured in years, the diffusion rate of the dissolved oxygen through the increasingly thick overlying yellow-green layer could become rate-limiting and not the reaction of oxygen with $\mathrm{UO}_{2}$. In the end, the effect of temperature on the rate of the reaction of $\mathrm{UO}_{2}$ with dissolved oxygen would have no influence on the long-term kinetics. The role of the overlying yellow-green crust is examined in more detail later in this report.

For simplicity, the temperature dependence of the diffusivity of water-dissolved oxygen into the original sludge solids layer, which typically is $\sim 75$ volume $\%$ water, is assumed to be that of oxygen in water. The diffusion coefficient of oxygen in water is approximately halved (0.478) by cooling from $51^{\circ} \mathrm{C}\left(4.16 \times 10^{-5} \mathrm{~cm}^{2} / \mathrm{s}\right)$ to $20^{\circ} \mathrm{C}\left(1.99 \times 10^{-5} \mathrm{~cm}^{2} / \mathrm{s}\right)$ (fit from data presented by Ferrell and Himmelblau 1967). This decrease is largely due to the increase in water viscosity with decreasing temperature.

Overall, the projected adjustment to the settled $\mathrm{UO}_{2}$ oxidation rate in air-saturated water at $20^{\circ} \mathrm{C}$ due to decreased oxygen concentration and diffusivities in water would be $(0.312 \times 0.478=) 0.149$. That is, the rate in air-saturated water at $20^{\circ} \mathrm{C}$ would be 0.149 -times the rate observed at $51{ }^{\circ} \mathrm{C}$ pure $\mathrm{O}_{2}$-saturated water (Equation 3.2). The rate in air-saturated water at $20^{\circ} \mathrm{C}$ is shown in Equation 3.3:

$\mathrm{UO}_{2}$ oxidation rate:

$20^{\circ} \mathrm{C}$ water, $0.21 \mathrm{~atm}_{2}$

$$
\begin{aligned}
\text { Oxidation depth, } \mathrm{mm}= & 0.149 \times 0.325 \times(\text { time }, \text { days })^{0.5}= \\
& 0.0485 \times(\text { time }, \text { days })^{0.5}
\end{aligned}
$$


The rate expressed in Equation 3.3 shows that the projected oxidation depth, in millimeters, is 0.0485 times the square root of the oxidation time, in days. Calculations to account for oxygen concentrations and diffusivities in water as functions of temperature at $10,20,30$, and $40^{\circ} \mathrm{C}$ in air-saturated water show the respective coefficients - $0.0456,0.0485,0.0531$, and 0.0594 - to increase moderately with temperature. The projected settled $\mathrm{UO}_{2}$ oxidation depths at $10,20,30$, and $40^{\circ} \mathrm{C}$ for up to 50 years time are plotted in Figure 3.10. Because of the parabolic kinetics, in which the growing thickness of the overlying metaschoepite crust increasingly impedes the diffusion of aerated water to the $\mathrm{UO}_{2}$, the projected extent of oxidation is only about $6 \mathrm{~mm}$ after 50 years at $\sim 10^{\circ} \mathrm{C}$ and $\sim 7 \mathrm{~mm}$ after 50 years at $30^{\circ} \mathrm{C}$.

An alternative analysis of uranium oxide oxidation depth driven by the diffusion of fully aerated water into a 50-inch-deep equimolar mixture of $\mathrm{UO}_{2.25}: \mathrm{UO}_{2}: \mathrm{UO}_{3} \cdot 2 \mathrm{H}_{2} \mathrm{O}$, equivalent to $\mathrm{UO}_{2.42} \cdot 0.66 \mathrm{H}_{2} \mathrm{O}$, to emulate sludge storage conditions in large-diameter containers was prepared (Appendix A by GA Whyatt in Schmidt and Delegard 2003). Mass transfer of the oxygen into the $\mathrm{UO}_{2.42} \cdot 0.66 \mathrm{H}_{2} \mathrm{O}$ sludge to form $\mathrm{UO}_{3} \cdot 2 \mathrm{H}_{2} \mathrm{O}$ from the $\mathrm{UO}_{2.25}: \mathrm{UO}_{2}$ was assumed to be limited by the rate at which the oxygen could diffuse through the sludge with the sludge providing a barrier to water circulation but no impediment to diffusion of the dissolved oxygen in the water. It was also assumed that the oxygen concentration in the overlying water remained at equilibrium saturation at $20^{\circ} \mathrm{C}$ and that the diffusivity of the sludge was the same as that for water at $20^{\circ} \mathrm{C}$; i.e., $2 \times 10^{-5} \mathrm{~cm}^{2} / \mathrm{s}$ (nearly identical to that projected from the data of Ferrell and Himmelblau 1967). The reaction to form $\mathrm{UO}_{3} \cdot 2 \mathrm{H}_{2} \mathrm{O}$ from $\mathrm{UO}_{2.25}$ and $\mathrm{UO}_{2}$ was assumed to be rapid compared with the diffusion of aerated water through the sludge layer.

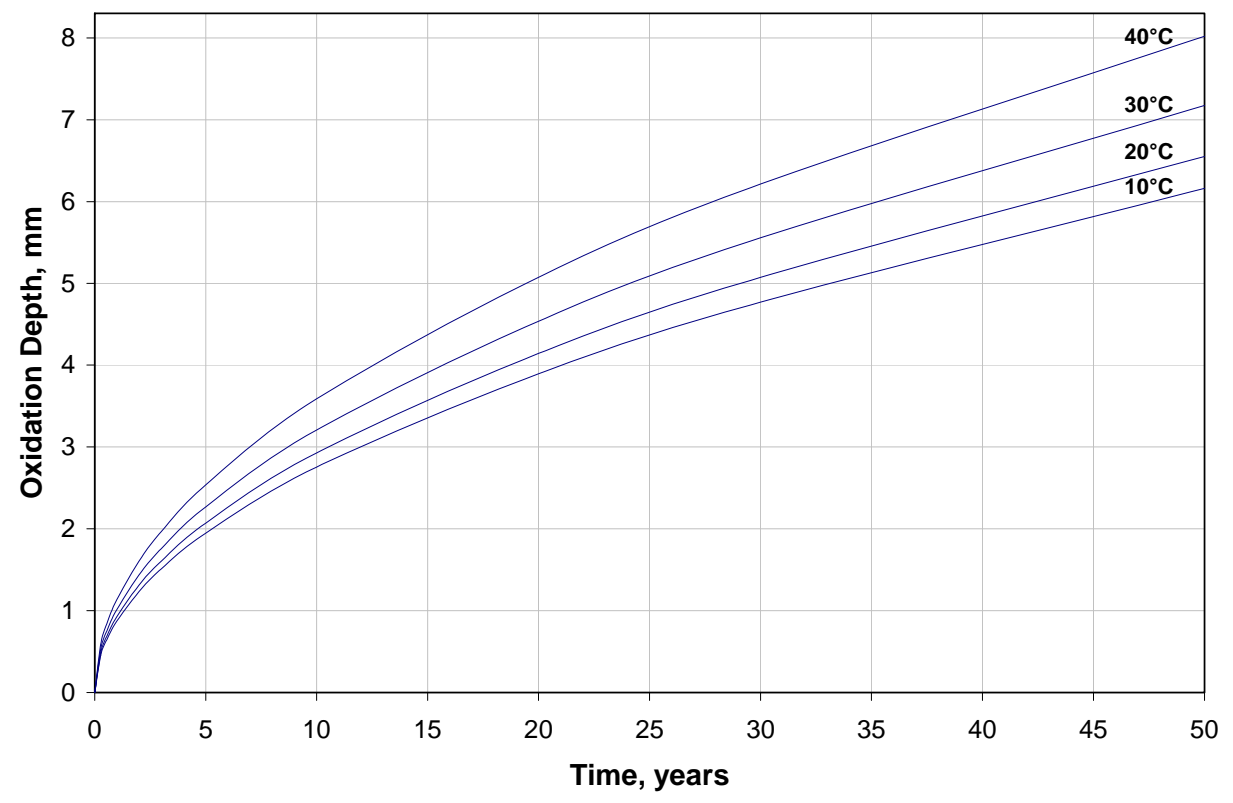

Figure 3.10. Depth of Settled $\mathrm{UO}_{2}$ Solids Oxidation to $\mathrm{UO}_{3} \cdot 2 \mathrm{H}_{2} \mathrm{O}$ as a Function of Temperature and Time

Two uranium concentrations in the sludge, $0.30 \mathrm{~g} / \mathrm{cm}^{3}$ and $0.04 \mathrm{~g} / \mathrm{cm}^{3}$, were considered in the analysis by Whyatt (Schmidt and Delegard 2003). In comparison, the starting settled $\mathrm{UO}_{2}$ bulk density in the present testing, $\sim 2.45 \mathrm{~g} / \mathrm{cm}^{3}$ (Sinkov et al. 2008) and based on the presence of only $\mathrm{UO}_{2}$ and water in 
the settled material, provides a uranium concentration of $1.40 \mathrm{~g} / \mathrm{cm}^{3}$. A 50:50 (mole basis) $\mathrm{UO}_{2}: \mathrm{UO}_{3} \cdot 2 \mathrm{H}_{2} \mathrm{O}$ mixture has $\sim 1.69 \mathrm{~g} / \mathrm{cm}^{3}$ bulk density (Sinkov et al. 2008) and uranium concentration of $0.54 \mathrm{~g} / \mathrm{cm}^{3}$.

A starting equimolar mixture of $\mathrm{UO}_{2.25}: \mathrm{UO}_{2}: \mathrm{UO}_{3} \cdot 2 \mathrm{H}_{2} \mathrm{O}$ was posited in Whyatt's analysis (Appendix A of Schmidt and Delegard 2003). The $\mathrm{UO}_{2.25}$ is equivalent to $0.75\left(\mathrm{UO}_{2}\right) \cdot 0.25\left(\mathrm{UO}_{3}\right)$. In actuality, the $\mathrm{UO}_{3}$ is hydrated, so the equivalent formula is $0.75\left(\mathrm{UO}_{2}\right) \cdot 0.25\left(\mathrm{UO}_{3} \cdot 2 \mathrm{H}_{2} \mathrm{O}\right)$ so that the equimolar $\mathrm{UO}_{2.25}: \mathrm{UO}_{3} \cdot 2 \mathrm{H}_{2} \mathrm{O}$ mixture is:

$$
\begin{aligned}
& 1 / 3\left[0.75\left(\mathrm{UO}_{2}\right) \cdot 0.25\left(\mathrm{UO}_{3} \cdot 2 \mathrm{H}_{2} \mathrm{O}\right)\right]+1 / 3 \mathrm{UO}_{2}+1 / 3\left(\mathrm{UO}_{3} \cdot 2 \mathrm{H}_{2} \mathrm{O}\right) \equiv \\
& 0.583 \mathrm{UO}_{2}: 0.417 \mathrm{UO}_{3} \cdot 2 \mathrm{H}_{2} \mathrm{O} \equiv \\
& \mathrm{UO}_{2.417} \cdot 0.833 \mathrm{H}_{2} \mathrm{O}
\end{aligned}
$$

or 58.3:41.7 $\mathrm{UO}_{2}: \mathrm{UO}_{3} \cdot 2 \mathrm{H}_{2} \mathrm{O}$. This mixture has a bulk density of $\sim 1.69 \mathrm{~g} / \mathrm{cm}^{3}$ (Sinkov et al. 2007) and, by calculation, a uranium concentration of $0.656 \mathrm{~g} / \mathrm{cm}^{3}$.

The analysis for $0.3 \mathrm{~g} \mathrm{U} / \mathrm{cm}^{3}$ in settled sludge predicted a 5-cm depth of complete oxidation to form $\mathrm{UO}_{3} \cdot 2 \mathrm{H}_{2} \mathrm{O}$ after 30 years at an unstated temperature (likely $\sim 20^{\circ} \mathrm{C}$ based on the stated diffusion rate; Appendix A by Whyatt in Schmidt and Delegard 2003). According to Whyatt's previous analysis, the rate of the oxidation front progression was nearly linear with time and thus showed no increasing impediment to diffusion caused by the increasing depth of the oxidation product with time. In contrast, the oxidation rate model in the present work, as shown in Figure 3.9 and Figure 3.10 and the associated discussion, predicts only about a $5-\mathrm{mm}$ penetration after 30 years at $20^{\circ} \mathrm{C}$. The lower penetration depth is predicted in the present analysis because the barrier to diffusion formed by the oxidized (metaschoepite) layer forces the reaction to proceed according to parabolic kinetics proportional to time ${ }^{1 / 2}$.

In both the oxidation/penetration depth analysis performed here and the previous evaluation performed by Whyatt (Schmidt and Delegard 2003), relatively little oxidation of $\mathrm{UO}_{2}$ to $\mathrm{UO}_{3} \cdot 2 \mathrm{H}_{2} \mathrm{O}$ is expected during stagnant long-term storage of sludge with high fractions of uranium oxide in STSCs at T Plant.

\subsubsection{Oxidation State Testing}

The uraninite used in the testing was analyzed to be essentially pure with only about $0.4 \% \mathrm{U}(\mathrm{VI})$. However, the $\mathrm{UO}_{2}$ contains nanometer-sized particles extremely susceptible to rapid initial oxidation such that $\sim 10 \%$ conversion to U(VI) occurs within about 3 minutes upon exposure of the starting slurry to oxygenated water (Sinkov et al. 2008).

Because of this rapid oxidation, the starting uraninite used in this testing, derived from the same bottle of $\mathrm{UO}_{2}$ as originally analyzed to be $0.4 \% \mathrm{U}(\mathrm{VI})$, was found by spectrophotometry to contain $9.6 \%$ $\mathrm{U}(\mathrm{VI})$ (Table 3.1). The settled $\mathrm{UO}_{2}$ removed for testing following 31 and 71 days of oxygenated water exposure at $50^{\circ} \mathrm{C}$ was stirred to homogenize the material. The 31-day test showed $17.7 \% \mathrm{U}(\mathrm{VI})$ while the 71-day test showed $21.7 \% \mathrm{U}(\mathrm{VI})$. The U(VI) concentration after 128 days for similarly homogenized material was $26.2 \%$, and the 185 -day material was $32.9 \% \mathrm{U}(\mathrm{VI})$.

The apparent deceleration in the oxidation rate can be linked to two factors. First, the diffusion of the dissolved oxygen oxidant through the crust to the unreacted $\mathrm{UO}_{2}$ became more constrained as the crust 
thickened. Second, the susceptibility of $\mathrm{UO}_{2}$ to oxidation depends on the $\mathrm{UO}_{2}$ particle or agglomerate size. In loading the $\mathrm{UO}_{2}$ into the centrifuge cones, the largest particles would settle most rapidly with the finest-sized particles settling last. Because the rate of $\mathrm{UO}_{2}$ oxidation by dissolved oxygen is proportional to the particle surface area and thus to the particle diameter (Sinkov et al. 2008), the finest-sized particles at the top of the settled $\mathrm{UO}_{2}$ are also the most rapidly oxidized and would have ample time during settling to react with the available convectively transported dissolved atmospheric oxygen. However, because the solids concentration in the $\mathrm{UO}_{2}$ slurry was so great, the settling was hindered such that most of the small particles were carried with the larger particles. Therefore, the $\mathrm{UO}_{2}$ oxidation rate decelerated because of oxygen diffusion impediments.

\subsubsection{Scanning Electron Microscopy}

Solids from Test 4 , which had 185 days exposure to $51^{\circ} \mathrm{C}$ oxygenated water, were harvested for SEM examination. Samples of the upper loose particles (Figure 3.11 and Figure 3.12), the bottom $\mathrm{UO}_{2}$ particles (Figure 3.13), and the intermediate crust (Figure 3.14) were examined. Two particle habits, square blocks and hexagonal or octagonal plates and rosettes, are present in the loose surface solids, as shown in Figure 3.11 and Figure 3.12. It can be seen that the blocky particles are in the process of etching or dissolving as shown by eroded crevices while plates and rosettes, some as big as $100 \mu \mathrm{m}$ (not depicted here), are growing. Oxidation state analyses show that the upper solids are pure U(VI); i.e., metaschoepite. The SEM observations thus give evidence for Ostwald ripening as manifest by recrystallization and crystal growth of the metaschoepite solids.

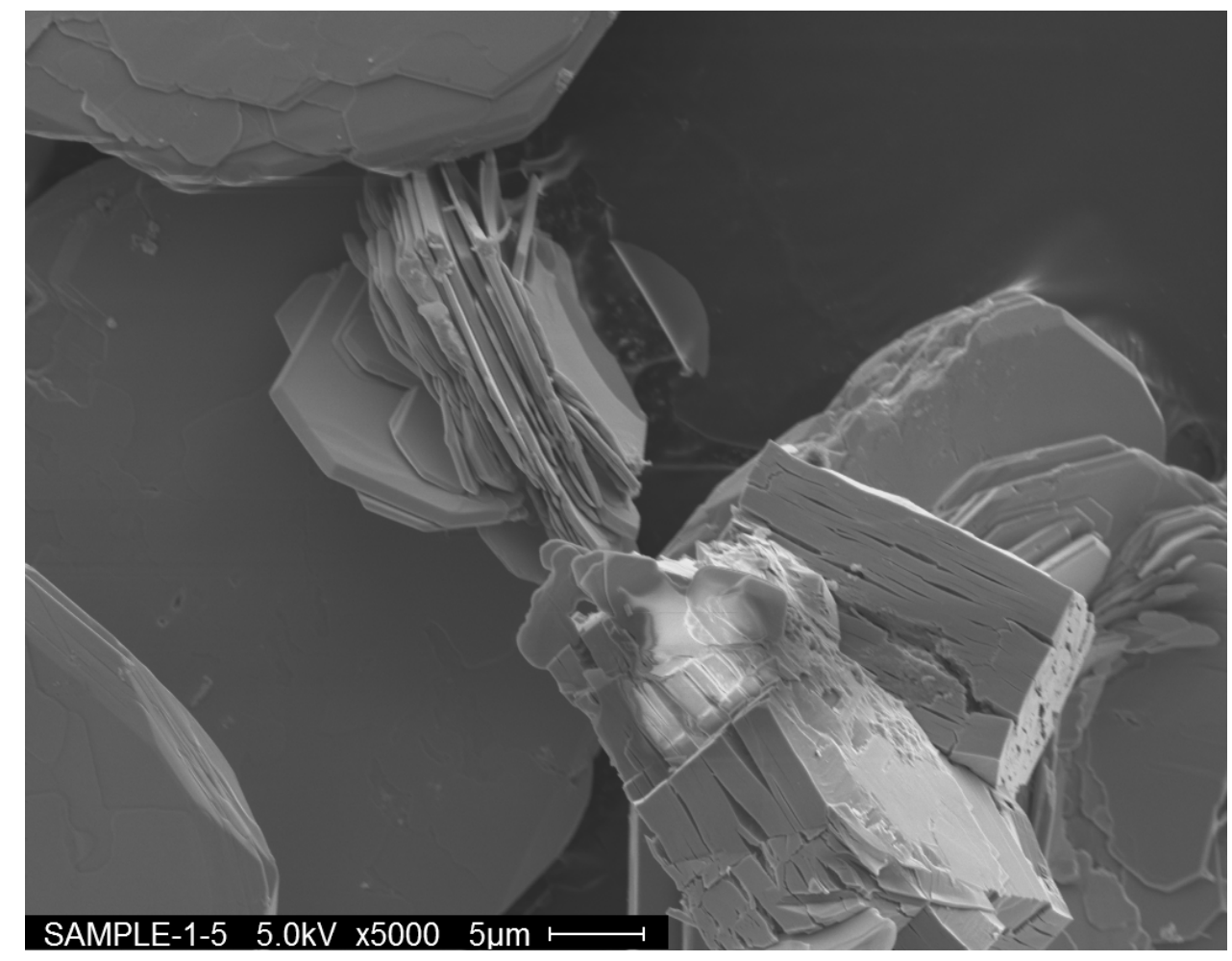

Figure 3.11. SEM Image of Loose Green-Yellow Particles Lying at the Top in Test 4. Note the etching and cracking of square blocky particles mid-lower right and the intact octagonal plates (some layered) elsewhere. 

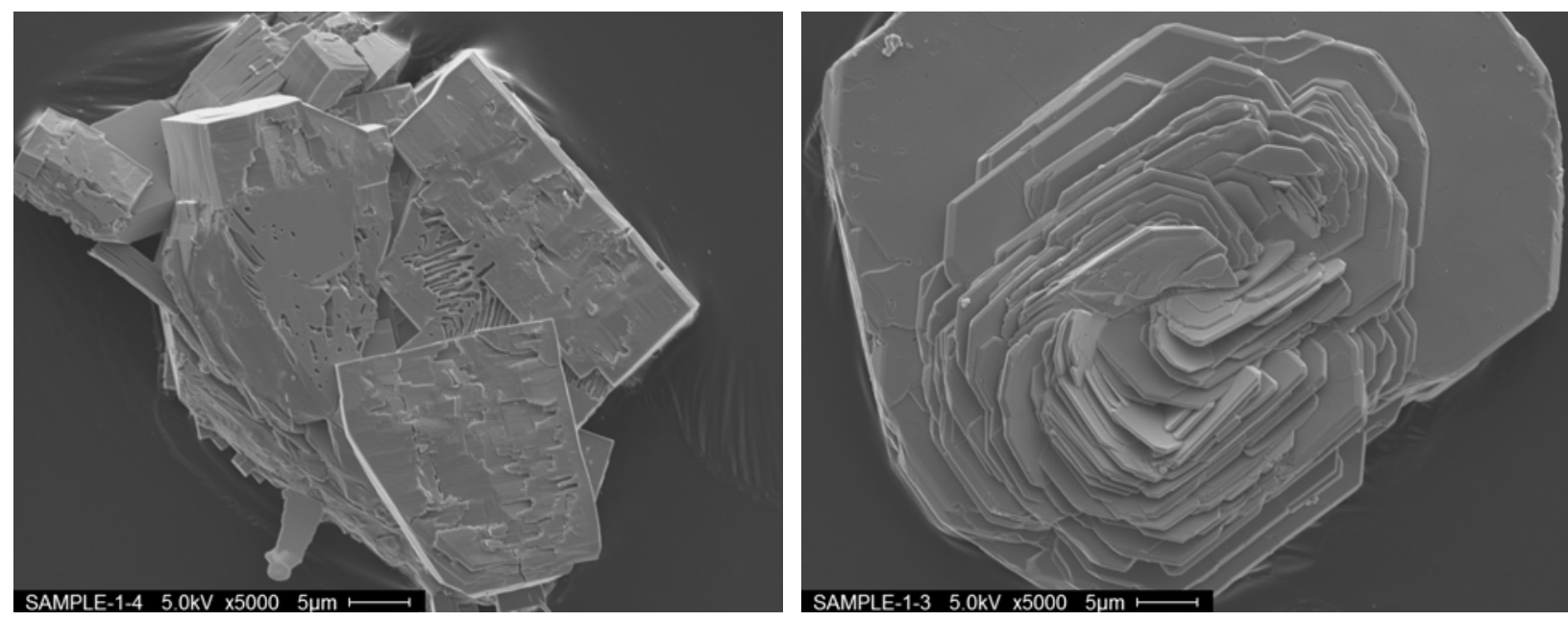

Figure 3.12. SEM Images of Loose Green-Yellow Particles Lying at the Top in Test 4. Note the erosion and cracking of square blocky particles in left image and the intact octagonal plate "rosette" in right image.

The starting $\mathrm{UO}_{2}$ is present as irregular agglomerates of sub-micron particles as shown in Figure 3.13. Mixtures of both the small non-oxidized agglomerates and the large oxidized metaschoepite particles are found in the region of transition between the two types of material.
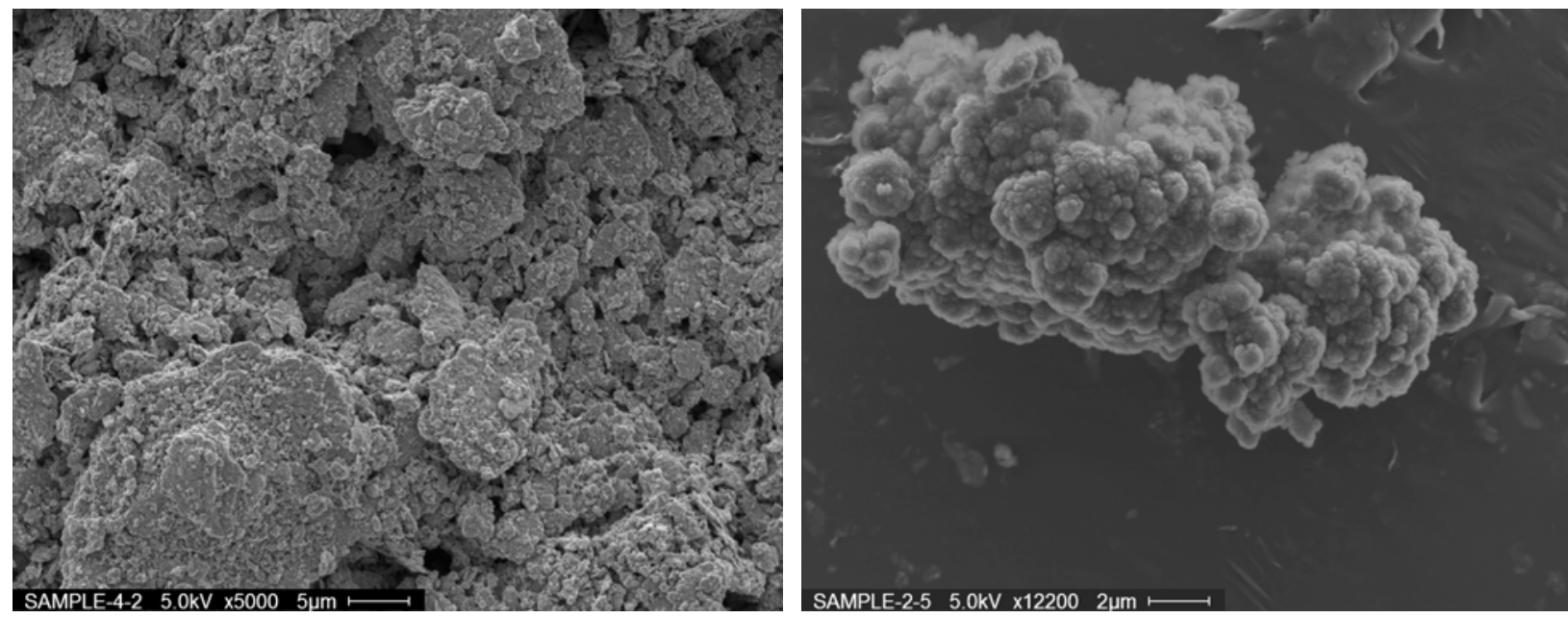

Figure 3.13. SEM Images of Black-Brown Particles Found at the Bottom in Test 4. Note the indistinct/irregular flake-like shapes dotted with sub-micron particles in the left image and isolated agglomerate of sub-micron particles in the right image.

Pronounced and extensive intergrowth of metaschoepite is found in the agglomerated crust depicted in Figure 3.14. The crust layer spanned the $\sim 18$ - $\mathrm{mm}$ centrifuge tube diameter and was durable during manipulation in its retrieval and handling. The appearance of the crust in the SEM images supports the postulate that the crust strength arises from the intergrowth and layered overlap of the metaschoepite crystals to form a continuous solid. The postulate that metaschoepite crystal growth contributes to shear strength, enhanced by metaschoepite's relatively high solubility, was advanced in a recent overview of K Basin sludge agglomeration phenomena (Hill 2010). 


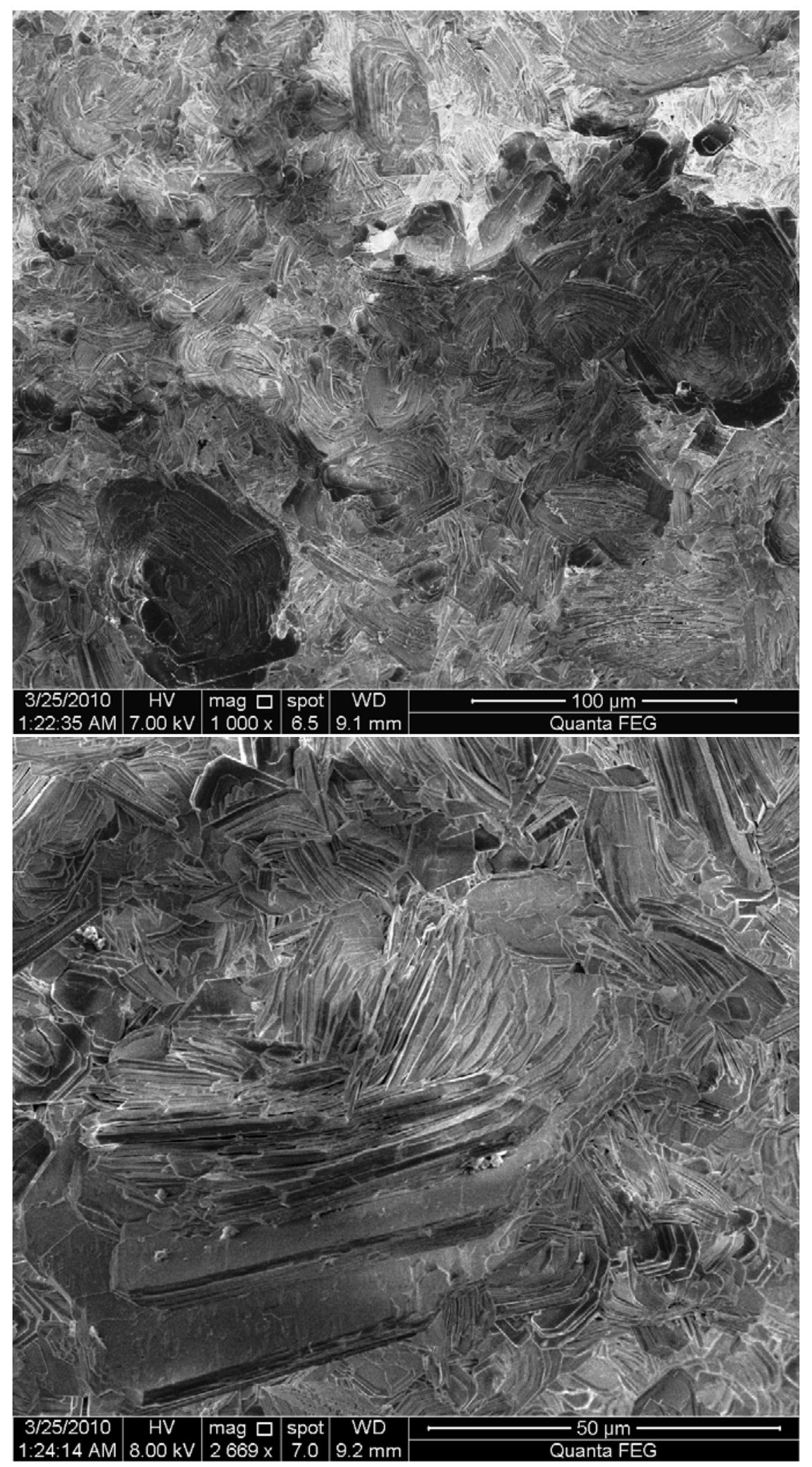

Figure 3.14. SEM Images of Intergrown Agglomerated Crust Layer Solids in Test 4, 185 Days 


\subsubsection{Strength Testing}

The solids in the centrifuge cones were probed by spatula upon sampling at $31,71,128$, and 185 days. The upper settled solids layer (Figure 3.2, right) showed no particular strength beyond that of the lower solids settled after 31 days of exposure. The light-green solids in the upper layer, when disturbed by a spatula, settled quickly like fine sand but offered no noticeable self-adhesion or agglomeration. The underlying dark-green solids were much finer and settled much more slowly than the upper green solids. The underlying dark layer showed no self-adhesion. After probing tests, the solids were mixed thoroughly by the spatula so that a representative sample could be obtained for analyzing the oxidation state of uranium.

In contrast, the upper solids in the samples probed after 71, 128, and 185 days (Figure 3.3 through Figure 3.5) showed observable strength in the upper layer and were able to support the $\sim 6.2$-gram weight of the spatula at all tested points on the surface. As in the 31-day testing, the upper solids were loose and settled quickly after suspension in the supernatant water by scraping and swirling from the spatula. The crust from the 71-day test was broken by the spatula and formed a flake $\sim 3-\mathrm{mm}$ across. The dark material underlying the crust, when probed by the spatula, showed no significant strength and appeared to have built no additional strength since original settling 2 months before. The crust from the 128-day test was punctured, it moved up the centrifuge tube, and then it was broken so that it could be taken out for closer examination (Figure 3.15). The crust was easily broken and crushed by spatula (like compressed fine soil) and showed little strength but was more than sufficiently strong to support its own weight. The crust thickness continued to increase with time as shown in Table 3.1.

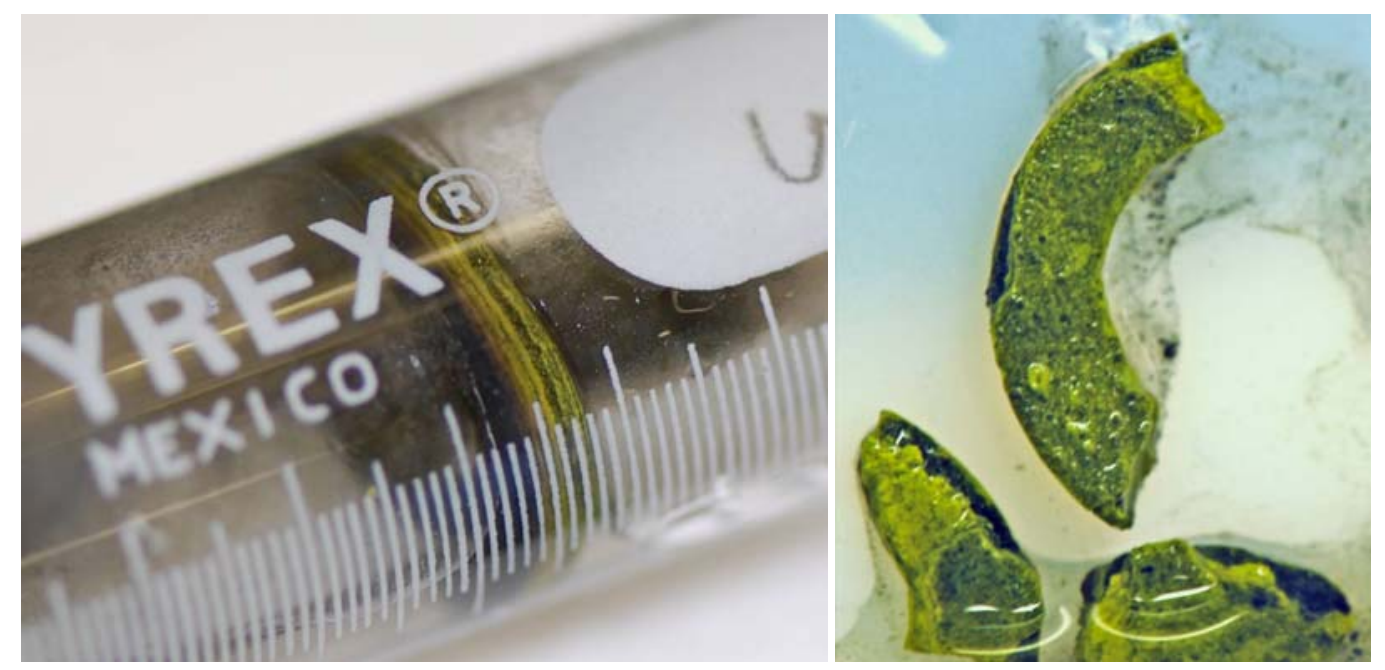

Figure 3.15. Solids Crust from the 128-Day Test: left—crust being moved up the centrifuge tube; right — crust fragments in a plastic weighing boat

It is likely that the precipitation/re-precipitation and particle size increase by Ostwald ripening and intergrowth as well as self-cementation of the green and yellow U(VI) solids as seen in Figure 3.14 are responsible for the strength shown by the crust and also would contribute to the oxygen diffusion barrier. The underlying $\mathrm{UO}_{2}$ certainly did not build significant strength in the testing done through 185 days. The 287-day sample was kept intact for possible future studies. 


\subsubsection{Liesegang Banding}

The alternating bands observed in these experiments are the most striking visual feature of the $\mathrm{UO}_{2}$ oxidation testing. The banding is reminiscent of bands observed in other chemical systems and in geological settings wherein chemical reactions occur by diffusion of a reactant through a stationary phase. This "Liesegang Banding"(a) or rhythmic precipitation phenomenon is illustrated in Figure 3.16 for fractured faces on basalt and in a piece of ignimbrite, a type of settled volcanic ash. In both instances, diffusion of oxygenated water occurred-into narrow cracks in larger basalt pieces and through cemented particles in the porous ignimbrite. In both cases, aerated water reacted with the exposed reduced iron $[\mathrm{Fe}(\mathrm{II})]$ to form the bands of precipitated oxidized iron $[\mathrm{Fe}(\mathrm{III})]$ marked by the dark-brown coloration. The oxidized iron oxide precipitation bands form in the direction perpendicular to the path of the diffusing agent by the interaction of the diffusing oxidant with the soluble reduced iron released by weathering of the stationary rock solids.

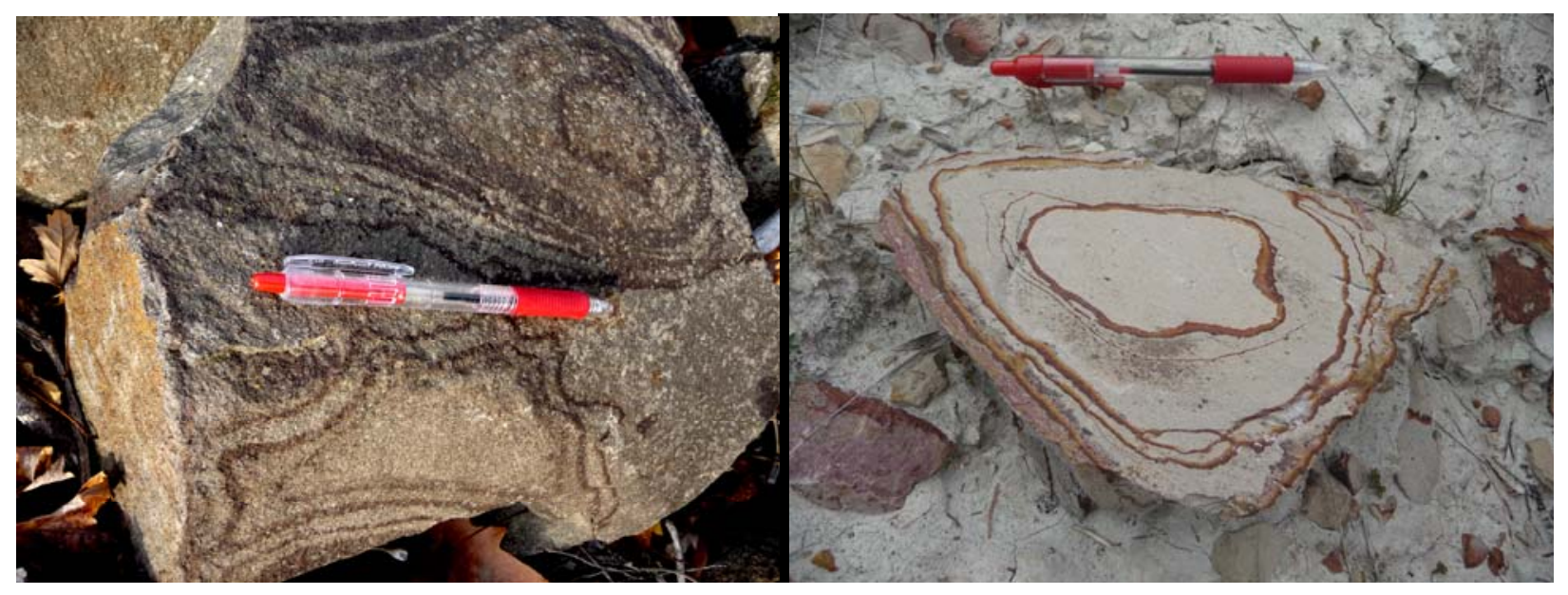

Figure 3.16. Liesegang Rings in Basalt (left) and Ignimbrite (right). Found, respectively, in Columbia River Dike near Hains Avenue, Richland, Washington, and John Day Fossil Beds, Sheep Rock Unit, Oregon.

Liesegang banding was named after Raphael Eduard Liesegang who, in 1896, observed the reaction of potassium dichromate, cast as a dilute solution in a thin agar gel layer, with silver nitrate solution that had been added as a drop to the middle of the gel layer. As the silver ion diffused outwardly into the gel, it encountered the dichromate and precipitated to form silver dichromate in a ring around the point of silver ion addition. With time, additional rings of silver dichromate formed concentrically outward from the initial ring. The following year, Wilhelm Ostwald postulated a mechanism for this phenomenon, hypothesizing that the dichromate becomes locally depleted from the surrounding volume as it diffuses to the precipitated silver dichromate particles to add to their size (i.e., ripen). In doing so, regions ahead and behind the precipitating band are left denuded of dichromate. As the silver ion continues to diffuse downgradient from the precipitated band through the gel, it begins to encounter more dichromate. With sufficient dichromate concentration, supersaturation again is reached and another region of silver dichromate precipitate occurs.

(a) Liesegang Banding is defined as "Colored or compositional rings or bands in a fluid-saturated rock due to rhythmic precipitation. Also known as Liesegang rings." (McGraw-Hill 2003) 
The explanation offered by Ostwald is qualitative. For a more detailed and semi-quantitative mechanistic understanding, including the progression of band width and pitch and the effects of concentration, precipitate particle size, and particle growth, more complex mathematical explanations have since been offered. However, most subsequent explanations of Liesegang banding begin with some variation of Ostwald's mechanism (Krug and Brandtstädter 1999).

Dissolved oxygen is the advancing reactant in the present case of stationary settled $\mathrm{UO}_{2}$ solids. It is postulated that the oxidation of $\mathrm{UO}_{2}$ by dissolved oxygen initially forms soluble $\mathrm{U}(\mathrm{VI})$. The dissolved $\mathrm{U}(\mathrm{VI})$ concentration increases until it exceeds its solubility and precipitates as $\mathrm{UO}_{3} \cdot 2 \mathrm{H}_{2} \mathrm{O}$. The dissolved $\mathrm{U}(\mathrm{VI})$ in the surrounding region then diffuses to the precipitating $\mathrm{UO}_{3} \cdot 2 \mathrm{H}_{2} \mathrm{O}$ and depletes the excess dissolved $\mathrm{U}(\mathrm{VI})$ in this region. The diffusing dissolved oxygen front continues into relatively fresh $\mathrm{UO}_{2}$, and the cycle is repeated. Alternatively, a secondary dissolution and reprecipitation of U(VI) phases may be occurring. This latter explanation is more consistent with the alternating layers of yellow and green solids shown most strikingly in Figure 3.7 and the SEM observations of dissolving blocky crystals and growing hexagonal or octagonal crystals shown in Figure 3.11 and Figure 3.12.

\subsubsection{Settled Simulated KW Containerized Sludge Slurry Behavior Under Oxygen at $51^{\circ} \mathrm{C}$}

Four tests (items S-1 through S-4) of the exposure of a KW containerized sludge simulant to $51{ }^{\circ} \mathrm{C}$ oxygenated water were performed. Oxygenation was attained by routing humidified $99.99 \%$ pure oxygen into the gas space above the settled solids and supernatant water. A parallel test item (S-control) was exposed to $51^{\circ} \mathrm{C}$ water but without oxygenation. The S-control test and items S-2, S-3, and S-4 were kept at temperature for 106 days; test S-1 was kept at temperature for 69 days. Experimental parameters and conditions are shown in Table 3.2.

Observations taken of the simulated sludge were settled volumes, visual appearance, and further oxidation of the initially 53.2:46.8 mole $\% \mathrm{U}(\mathrm{IV}): \mathrm{U}(\mathrm{VI})$ present, respectively, as the $\mathrm{UO}_{2}$ and $\mathrm{UO}_{3} \cdot 2 \mathrm{H}_{2} \mathrm{O}$ that were used in preparing the KW containerized sludge simulant. The settled volumes, densities, and oxidation state analyses at the measured times are shown in Table 3.2.

Table 3.2. Settled Volume, Density, and Extents of Oxidation in KW Containerized Simulant Sludge

\begin{tabular}{|c|c|c|c|c|c|c|c|c|c|c|c|}
\hline \multirow[b]{2}{*}{ Test ID } & \multicolumn{6}{|c|}{ Settled Volume, mL, at Times, days } & \multicolumn{2}{|c|}{ Density, $\mathrm{g} / \mathrm{cm}^{3}$} & \multicolumn{3}{|c|}{ Oxidation State Analysis } \\
\hline & 0 & 10 & 38 & 45 & 66 & 106 & Initial & Final & $\begin{array}{l}\mathrm{ET}, \\
\text { days }\end{array}$ & $\begin{array}{c}\% \\
\mathrm{U}(\mathrm{VI})\end{array}$ & $\begin{array}{l}\text { \% of Remaining } \\
\text { U(IV) Oxidized }\end{array}$ \\
\hline $\mathrm{UO}_{2}: \mathrm{UO}_{3} \cdot 2 \mathrm{H}_{2} \mathrm{O}$ & & & & & & & & & 0 & 46.7 & 0 \\
\hline S-control & 4.55 & 4.55 & 4.45 & 4.40 & 4.40 & 4.30 & $1.30^{(\mathrm{a})}$ & $1.24^{(\mathrm{a})}$ & 106 & 52.6 & 10.9 \\
\hline S-1 & 4.75 & 4.35 & 3.65 & 3.55 & 3.40 & - & 1.26 & 1.33 & 69 & 71.5 & 46.4 \\
\hline S-2 & 5.15 & 4.70 & 3.95 & 3.85 & 3.80 & 3.25 & 1.25 & 1.38 & 106 & 76.8 & 56.4 \\
\hline S-3 & 5.05 & 4.65 & 3.90 & 3.80 & 3.50 & 3.05 & 1.29 & 1.52 & 106 & 78.7 & 60.0 \\
\hline $\mathrm{S}-4$ & 5.00 & 4.55 & 3.85 & 3.40 & 3.20 & 2.75 & 1.28 & 1.62 & 106 & 77.6 & 57.9 \\
\hline \multicolumn{7}{|c|}{$\begin{array}{r}\text { Average } \\
\text { viation at } 1 \sigma\end{array}$} & $\begin{array}{r}1.27 \\
\pm 0.02 \\
\end{array}$ & $\begin{aligned} & 1.51^{(\mathrm{b})} \\
\pm & 0.12\end{aligned}$ & & $\begin{array}{l}77.7^{(\mathrm{a})} \\
\pm 1.0\end{array}$ & $\begin{array}{l}58.1^{(\mathrm{a})} \\
\pm 1.8\end{array}$ \\
\hline
\end{tabular}

(a) Density is expected to increase with time as the solids settle. However, solid settling was small for test S-control, as shown in Figure 3.17. The observed density decrease is due to variability in estimating settled solids and solution volumes. (b) Averages for tests S-2, S-3, and S-4 after 106 days of settling. 


\subsubsection{Settled Volume}

Unlike the testing of settled $\mathrm{UO}_{2}$ using $51^{\circ} \mathrm{C}$ oxygenated water conditions, in which virtually no settled solids volume change occurred over the 287-day test duration, the oxygenated KW containerized sludge simulant settled significantly. The starting simulated sludge volumes used in each test, $\sim 5.0 \mathrm{~mL}$, correspond to a sludge depth of $\sim 4.85 \mathrm{~cm}$. The simulant in tests $\mathrm{S}-2$ and S-3 settled to about $78 \%$ of their starting depths after 106 days of exposure (Figure 3.17). The settled solids evidently were very delicate because one of the test items, S-4, which otherwise was similar to test items S-1 through S-3, abruptly lost about $4 \%$ of its starting depth when moved out of the thermostatted bath (and later returned) for a photograph at 42 days. These changes are apparent in comparing the 38- and 45-day settled volume data in Figure 3.17. In contrast, the S-control test settled volume did not change markedly when moved at the same time. The S-control test, also run at $51^{\circ} \mathrm{C}$ but without oxygen flow, settled much less than the tests exposed to oxygen, losing only about $3 \%$ of its starting depth in the same 106-day time period.

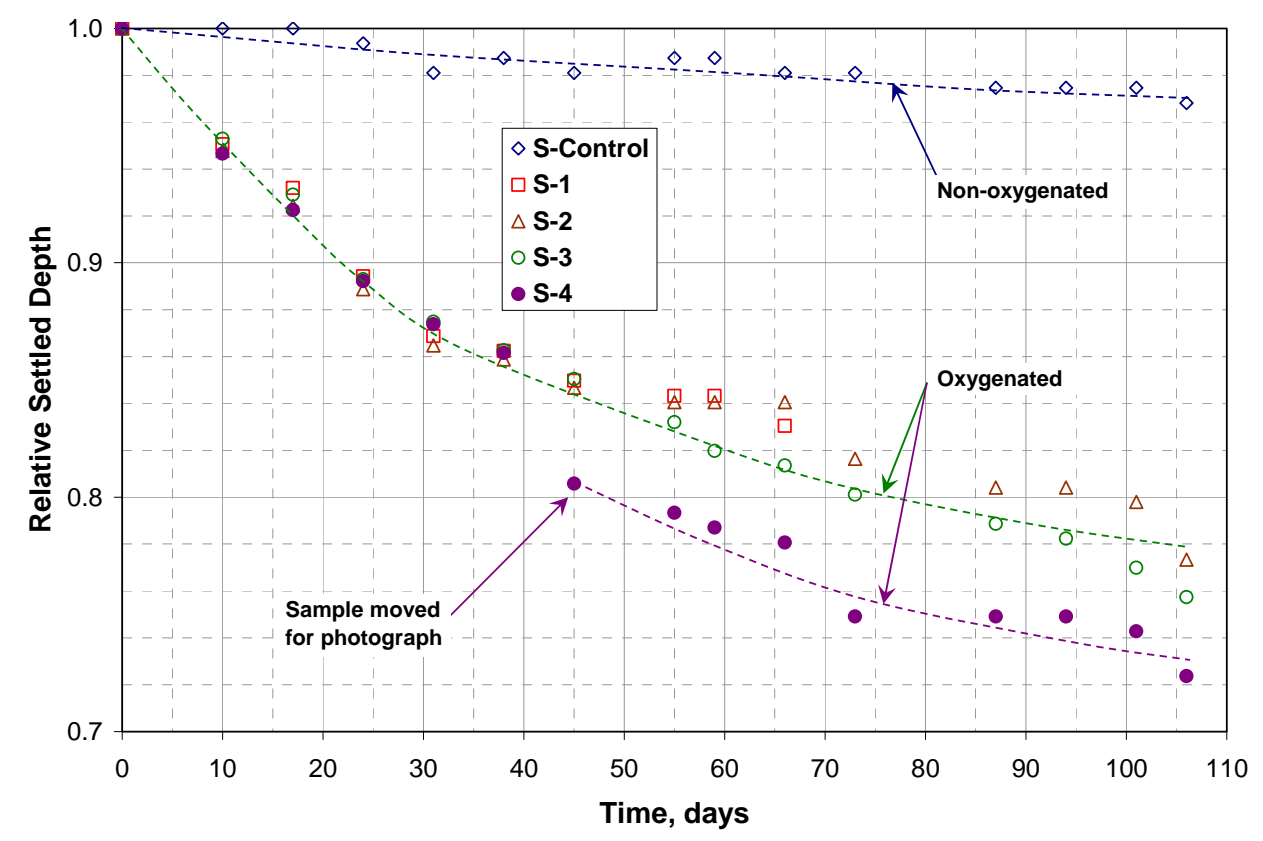

Figure 3.17. Relative Settled Depths of Non-Flocculated KW Containerized Sludge upon Exposure to Oxygenated and Non-Oxygenated $51^{\circ} \mathrm{C}$ Water

The presence of oxygen evidently was responsible for the marked difference in settling behavior between the S-control test run without oxygen and the S-1 through S-4 tests that were exposed to oxygenated water. Because no volume change was found for the $\mathrm{UO}_{2}$ tests that were run under similar conditions (Section 3.1.1), the shrinkage of the S-1 through S-4 tests could not be solely due to oxidation of the $\mathrm{UO}_{2}$. No change in settled solids volume occurred in the conversion of $\mathrm{UO}_{2}$ slurry to the tightly inter-grown $\mathrm{UO}_{3} \cdot 2 \mathrm{H}_{2} \mathrm{O}$. On the contrary, the conversion of $\mathrm{UO}_{2}$ solid particles to $\mathrm{UO}_{3} \cdot 2 \mathrm{H}_{2} \mathrm{O}$ particles should have increased the solids volume because of the greater uranium-specific volume of $\mathrm{UO}_{3} \cdot 2 \mathrm{H}_{2} \mathrm{O}$ $\left(\sim 64.4 \mathrm{~mL} / \mathrm{mole} \mathrm{U}\right.$ based on $5.00 \mathrm{~g} / \mathrm{cm}^{3}$ particle density) compared to that of $\mathrm{UO}_{2}(\sim 24.5 \mathrm{~mL} / \mathrm{mole} \mathrm{U}$ at $10.964 \mathrm{~g} / \mathrm{cm}^{3}$ particle density). 
However, the settled solids volume did collapse. It is speculated that the precipitating $\mathrm{UO}_{3} \cdot 2 \mathrm{H}_{2} \mathrm{O}$ particles could have occluded or coagulated the dispersed ferrihydrite particles and reduced the overall apparent solids' volume. No Optimer 7194 Plus flocculating agent was present in the S samples.

The solids settling led to an increase in the solids settled densities with time. The average initial settled density for items S-control, S-1, S-2, S-3, and S-4 was $1.27 \pm 0.02 \mathrm{~g} / \mathrm{cm}^{3}$. The settled density increased to $1.33 \mathrm{~g} / \mathrm{cm}^{3}$ for S-1 after 69 days and was $1.51 \pm 0.12 \mathrm{~g} / \mathrm{cm}^{3}$ for test items S-2, S-3, and S-4 after 106 days.

\subsubsection{Visual Appearance}

The visual appearances of the tests were registered by digital photography. Images of the S-control and S-4 tests are compared in Figure 3.18 through Figure 3.20 for $51^{\circ} \mathrm{C}$ heating durations of 41,69 , and 106 days. The decrease in the settled solids volume and increased depth of the lighter colored upper layer are immediately evident in comparing the images of test S- 4 as the heating duration increased. The lighter color is taken as evidence of oxidation of the near-black $\mathrm{UO}_{2}$ within that layer to yellow-green $\mathrm{UO}_{3} \cdot 2 \mathrm{H}_{2} \mathrm{O}$. The predominant red-brown color is attributed to ferrihydrite.

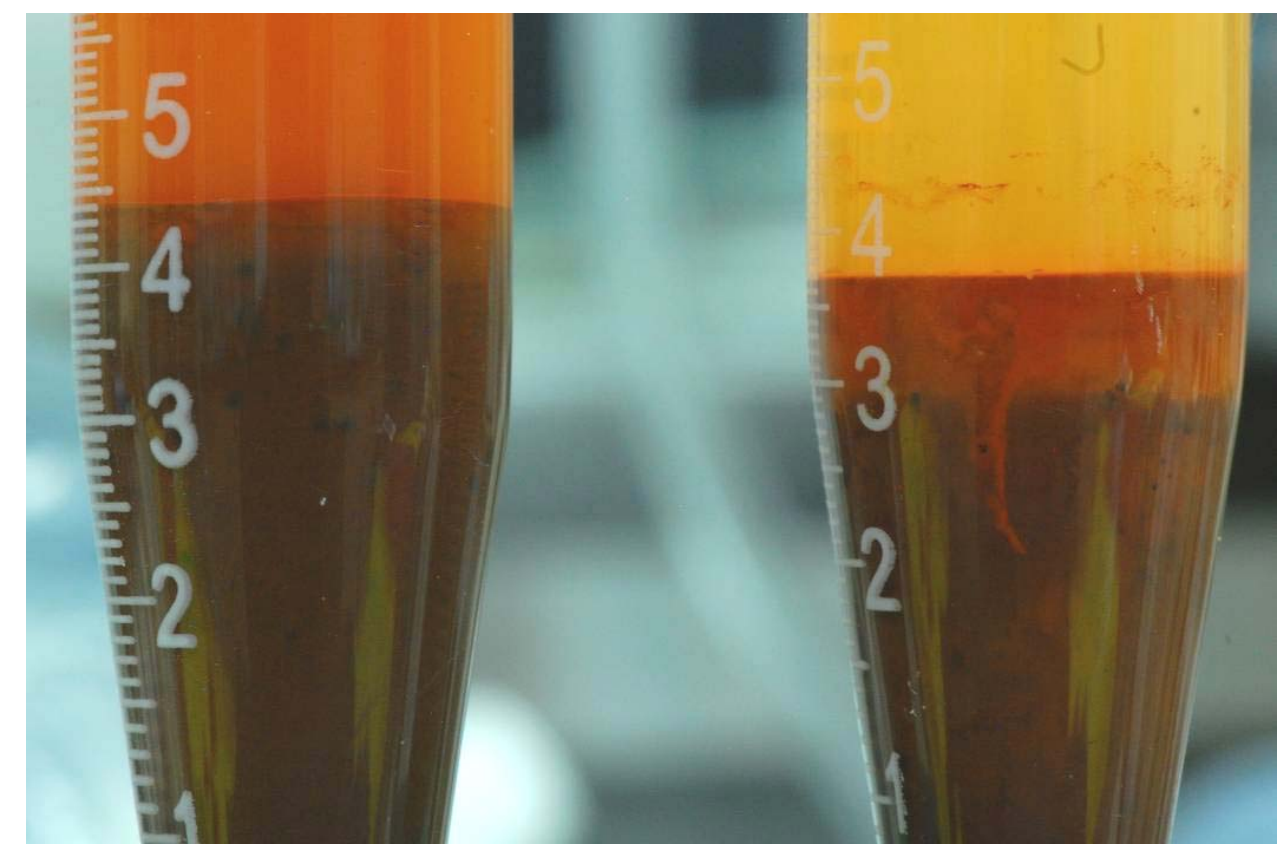

Figure 3.18. S-Control and S-4 Tests after 41 Days of Exposure to $51^{\circ} \mathrm{C}$ Oxygenated Water 


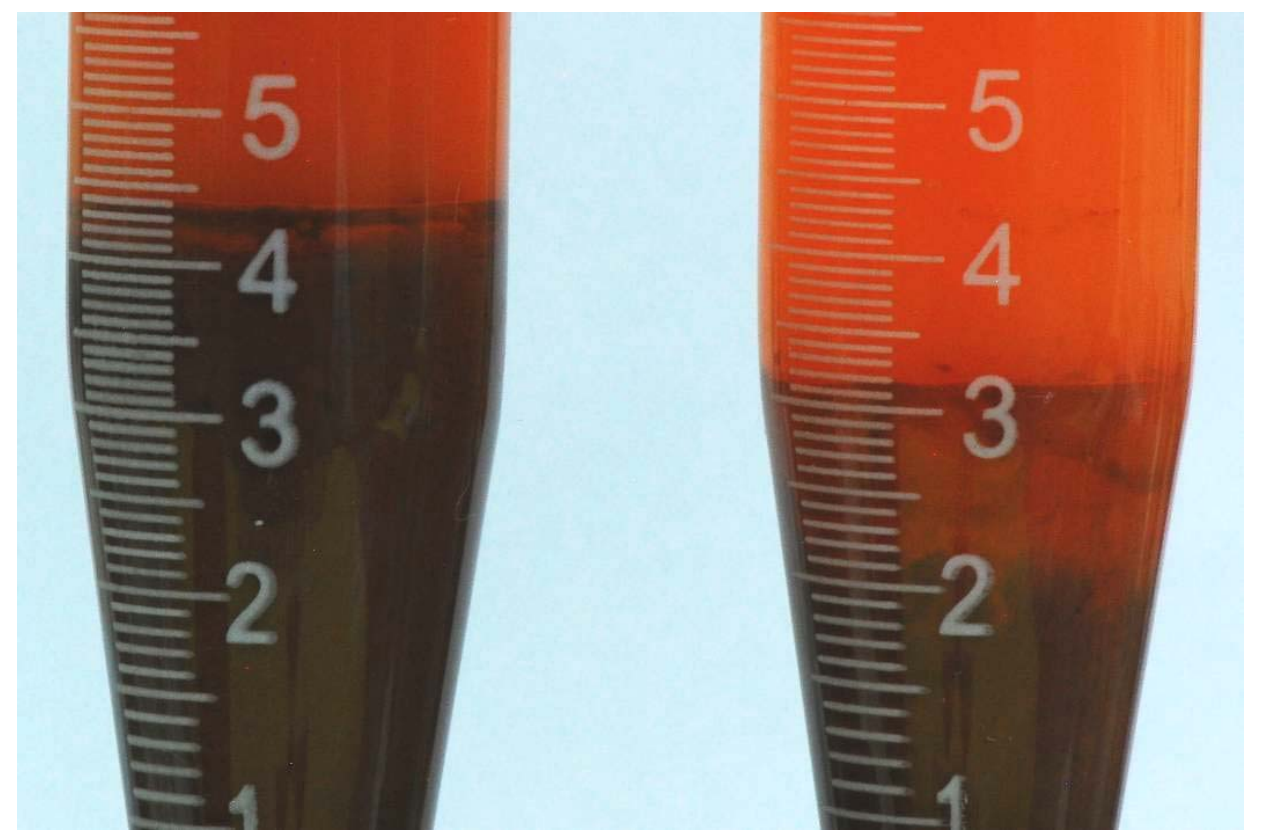

Figure 3.19. S-Control and S-4 Tests after 69 Days of Exposure to $51{ }^{\circ} \mathrm{C}$ Oxygenated Water

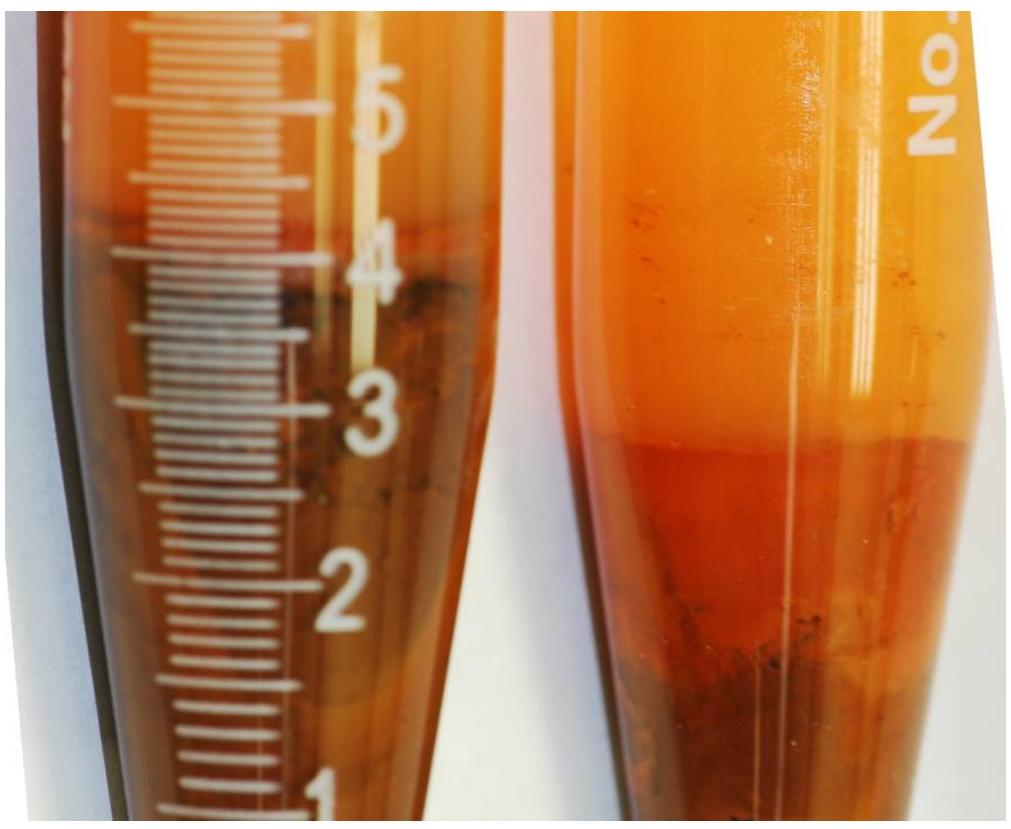

Figure 3.20. S-Control and S-4 Tests after 106 Days of Exposure to $51^{\circ} \mathrm{C}$ Oxygenated Water

The lighter-colored upper layer depth in test S-4 was about $5.8 \mathrm{~mm}$ after 41 days $\left(\sim 0.85 \mathrm{~cm}^{3}\right.$ or 23 volume\%), $7.0 \mathrm{~mm}\left(\sim 1.00 \mathrm{~cm}^{3} ; 32\right.$ volume\%) after 69 days, and $8.5 \mathrm{~mm}\left(\sim 1.25 \mathrm{~cm}^{3} ; 43\right.$ volume\%) after 106 days. The visible oxidation progression was more rapid in the full $\mathrm{KW}$ containerized sludge simulant tests than in the $\mathrm{UO}_{2}$ tests reported in Section 3.1.1. The oxidation boundaries observed in test $\mathrm{S}-4$ were not flat as seen in the $\mathrm{UO}_{2}$ oxidation tests but showed greater swirling or marbling as time progressed, perhaps reflecting lower strength compared with the $\mathrm{UO}_{2}$ tests. In contrast, the lighter colored upper layer of the S-control test remained flat and about $2 \mathrm{~mm}$ deep $(\sim 0.25 \mathrm{~mL})$ over the 106-day test duration. 


\subsubsection{Uraninite Oxidation}

The KW containerized simulant sludge was prepared using a $\mathrm{UO}_{2}: \mathrm{UO}_{3} \cdot 2 \mathrm{H}_{2} \mathrm{O}$ mixture. Oxidation state analysis before preparing the simulant showed it to be 53.2:46.8 U(IV):U(VI) (mole basis). The $\mathrm{U}(\mathrm{VI})$ portion for the S-control test increased to $52.6 \%$ after 106 days [i.e., about $10 \%$ of the U(IV) present at the beginning of the tests oxidized]. It is likely that much of this oxidation occurred from exposure to atmospheric oxygen during preparation of the simulant. Over the same 106-day test period, the U(VI) complement in the oxygenated KW containerized sludge simulant tests increased almost linearly with time as shown in Figure 3.21. Although some decrease in the rate of oxidation is observed as time increases, the oxidation does not follow parabolic rate kinetics (oxidation depth proportional to time $^{1 / 2}$ ) as observed for the $\mathrm{UO}_{2}$ testing reported in Section 3.1.1. As will be shown in the following sections, the upper solids layer had little strength, unlike the increasingly thick and continuous metaschoepite crust layer observed as oxidation proceeded in the $\mathrm{UO}_{2}$ oxidation testing.

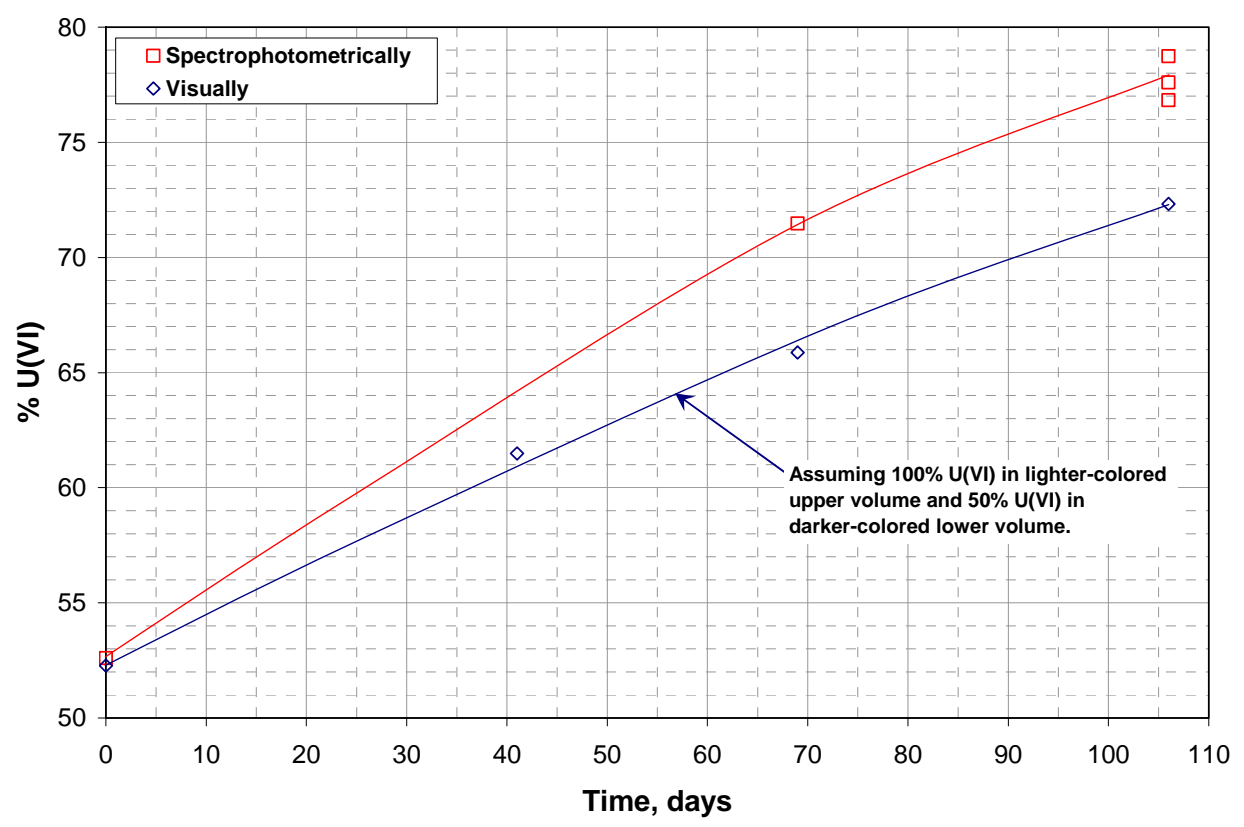

Figure 3.21. Oxidation Extent Observed Visually and by Spectrophotometry for KW Containerized Sludge Simulant Tests

The oxidation depth observed after 106 days in the tests with the KW containerized sludge simulant is about $8.5 \mathrm{~mm}$ versus about $3 \mathrm{~mm}$ for the $\mathrm{UO}_{2}$ settled solids oxidation over the same time period as interpolated from Figure 3.8. Thus, in the course of the oxidation testing, the KW containerized sludge simulant is more permeable to dissolved-oxygen transport than is the settled $\mathrm{UO}_{2}$. Based on the marbled appearances of the test items, the convective transport of oxygenated water likely contributed to the greater oxidation depths observed in the $\mathrm{KW}$ containerized sludge simulant relative to those observed in the $\mathrm{UO}_{2}$ testing described in Section 3.1.1.

Parallel behavior is seen for genuine sludge stored under analogous extended warm $\left(35 \pm 3^{\circ} \mathrm{C}\right.$; Delegard et al. 2005), semi-oxic (closed jar), and static laboratory hot cell conditions. It was found that uraninite phases $\left(\mathrm{UO}_{2}, \mathrm{UO}_{2.25}, \mathrm{UO}_{2.33}\right)$, initially observed by $\mathrm{XRD}$ in three uranium-rich $\mathrm{K}$ Basin sludge samples, were no longer present but, instead, had oxidized to metaschoepite and other U(VI) phases after 
9 to 12 years of hot cell storage (Delegard et al. 2007a). The three archive materials were $\mathrm{KC}-2 / 3$ Comp, 96-13 Solid Grad, and 96-13 KE Comp A. Two of the three, KC-2/3 Comp and 96-13 KE Comp A, already contained U(VI) phases when first characterized. The solids were originally $\sim 52$ to $74 \mathrm{wt} \%$ uranium (dry basis). The behaviors of these archive materials show that uraninite oxidation within genuine sludge occurs under conditions analogous to those of the KW containerized sludge simulant testing under $50^{\circ} \mathrm{C}$ oxygenated water. With the exception of sludge depth and the periodic handling of the samples over the years for maintenance and test activities, the hot cell conditions also are analogous to the radiological and thermal conditions expected for extended sludge storage in T Plant.

\subsubsection{Strength Testing}

Strength testing of the S-control, S-1, S-2, S-3, and S-4 tests were performed upon completion of the test intervals marked by treatment at $51^{\circ} \mathrm{C}$ with oxygenated water (tests $\mathrm{S}-1$ through $\mathrm{S}-4$ ) or nonoxygenated water (test S-control). Test S-1 was removed for strength examination after 69 days while tests S-2, S-3, and S-4 were replicates removed for examination after 106 days.

Test S-1, removed after 69 days of $51^{\circ} \mathrm{C}$ oxygenated water treatment, had insufficient strength to support the $\sim 6$-g weight of the mini-spatula. The upper $\sim 2$-mm of settled solids depth readily slumped when the test item was tipped about $45^{\circ}$ from vertical. Based on testing with kaolin simulants of known strength in larger sample jars, the slumping observations indicate that the shear strength in the KW simulant is $<52 \mathrm{~Pa}$ (Russell et al. 2010).

Tests S-control, S-2, S-3, and S-4 were removed for strength testing after 106 days. The strengths of each of these 106-day tests were similar to each other and qualitatively similar to the strength observed for test S-1 after 69 days of heating. Tests S-control and S-2 could not support the weight of the minispatula and showed no strength or agglomeration on gentle stirring. Test S-3 was gently inverted about 20 times to see if the solids could be readily dislodged by this action. About $0.3 \mathrm{~mL}$ from the top of the settled solids was moved by this treatment. The inverted $15-\mathrm{mL}$ tube then was lightly tapped to attempt to liquefy the moist solids. After about 10 such taps, the solids liquefied and flowed downward. The settled solids in test S-4 were probed by side-to-side motion of the mini-spatula. No crust or fracturing was observed by this treatment. Instead, the settled solids behaved like a loose mud. Aging and oxidation had little effect on the sludge's qualitative strength. This showed that the solids showed little self-agglomeration such that little particle-to-particle welding occurred.

Despite the lesser solids compaction with time shown in Figure 3.17 for S-control, which was heated without oxygenation, than for the other tests, which were heated with oxygenation, no noticeable strength differences were observed between S-control and the remaining more compact oxygenated tests.

\section{2 $\mathrm{UO}_{2} / \mathrm{UO}_{3} \cdot 2 \mathrm{H}_{2} \mathrm{O}$ and $\mathrm{KW}$ Containerized Sludge Simulant at $96^{\circ} \mathrm{C}$ Under Static Gas}

Higher temperature testing was conducted to determine the behavior of $\mathrm{UO}_{2} / \mathrm{UO}_{3} \cdot 2 \mathrm{H}_{2} \mathrm{O}$ and $\mathrm{KW}$ containerized sludge simulant at $96^{\circ} \mathrm{C}$ under static gas conditions. Anoxic aqueous corrosion of uranium metal in sludge $\sim 95^{\circ} \mathrm{C}$, followed by immobilization, is an alternative approach being evaluated for final sludge disposition. The present testing focused on potential formation of sludge agglomerates at the $95^{\circ} \mathrm{C}$ process operating temperature. 
The testing performed for this aspect of work is outlined in Table 2.2. Results of this testing have been presented in an associated document ${ }^{(a)}$ and are presented here for comparison with related studies described in Section 3.1.

Information on the densities, $\mathrm{pH}$, and crystallographic properties of the test materials is provided in Section 3.2.1. Discussions of the physical appearances of the starting and product materials are provided in Section 3.2.2.

\subsubsection{Properties of $\mathrm{UO}_{2} / \mathrm{UO}_{3} \cdot 2 \mathrm{H}_{2} \mathrm{O}$ and $\mathrm{KW}$ Containerized Sludge Simulant Heated at $96^{\circ} \mathrm{C}$}

Voids were generated upon heating the simulant sludges for all tests. In addition, fine, opaque redbrown suspensions were generated in Tests S-5 and S-6. As a result of the voids and solids dispersion, sludge volume measurement accuracies were degraded. The unevenness in the solid-liquid surface and lacunae in the settled solids meant that the settled volumes could only be measured on a best-effort basis based on real-time visual observation and review of photographs taken as the tubes were rotated through $90^{\circ}$ steps. Based on the photo reviews, uncertainties in settled solids volumes were estimated to be about $15 \%$ or better (including parallax error) so that the post-test settled density accuracy is estimated to be approximately $\pm 20 \%$ (relative) or better.

The settled density and $\mathrm{pH}$ results from the testing are provided in Table 3.3. Considering the uncertainty of the accuracy of the post-test settled density measurements, significant changes to settled density were not observed. However, the $\mathrm{UO}_{2}: \mathrm{UO}_{3} \cdot 2 \mathrm{H}_{2} \mathrm{O}$ sample density decreased about $9 \%$ (relative) with heating while the KW container sludge simulant density increased about $7 \%$ (relative) by heating. Again, these density estimates take into account, by visual judgment, the voids in the settled solids. Heating and time resulted in inconsequential decreases of about 0.2 to $0.3 \mathrm{pH}$ units for tests $\mathrm{U}-1, \mathrm{U}-2$, $\mathrm{U}-3, \mathrm{U}-4$, and S-5. An anomalous three-unit $\mathrm{pH}$ drop was measured for Test S-6.

Alteration of components in the sludge, particularly those such as metaschoepite, goethite, and gibbsite that are susceptible to dehydration reactions during heating, was investigated by XRD of the heated samples (U-3 and S-start) and their corresponding control (non-heated) counterparts (U-1 and S-6). The XRD scans are shown in Appendix A with further discussion of the XRD results.

Comparison of the XRD scans of the unheated and heated samples shows no evidence of dehydration reactions or change in material phases, although changes in peak intensities were noted. No peaks attributable to dehydrated schoepite or to boehmite were observed. The hydrated precursor compounds of metaschoepite, goethite, and gibbsite remained present in the heated products.

(a) Schmidt AJ and SI Sinkov. 2010. Evaluation of Potential Agglomeration of KW Container Sludge Simulant and 50/50 Uranium Oxide Mixture U(IV)/U(VI) with Heating. PNNL-19597, Pacific Northwest National Laboratory, Richland, Washington (limited distribution). 
Table 3.3. Settled Density and Solution pH Before and After Heating

\begin{tabular}{|c|c|c|c|c|c|}
\hline \multirow[b]{2}{*}{ Test ID } & \multirow[b]{2}{*}{$\begin{array}{c}\text { Simulant } \\
\text { Sludge Type }\end{array}$} & \multicolumn{2}{|c|}{ Solids Settled Density, $\mathrm{g} / \mathrm{cm}^{3}$} & \multicolumn{2}{|c|}{ Solution $\mathrm{pH}$} \\
\hline & & $\begin{array}{c}\text { Before } \\
\text { Heating }^{(a)}\end{array}$ & After Heating $^{(a)}$ & $\begin{array}{l}\text { Before } \\
\text { Heating }\end{array}$ & $\begin{array}{c}\text { After } \\
\text { Heating }\end{array}$ \\
\hline U-1 & \multirow{4}{*}{$\mathrm{UO}_{2}: \mathrm{UO}_{3} \cdot 2 \mathrm{H}_{2} \mathrm{O}$} & 1.90 & 1.76 & 8.94 & 8.62 \\
\hline $\mathrm{U}-2$ & & 1.98 & 1.82 & 8.99 & 8.69 \\
\hline $\mathrm{U}-3^{(\mathrm{b})}$ & & 1.84 & 1.84 & 8.87 & 8.69 \\
\hline$U-4^{(\mathrm{b})}$ & & 1.99 & 1.99 & 8.75 & 8.55 \\
\hline S-5 & \multirow{2}{*}{ KW Container } & 1.33 & 1.41 & 8.81 & 8.45 \\
\hline S-6 & & 1.34 & 1.44 & 9.03 & 6.09 \\
\hline \multicolumn{6}{|c|}{$\begin{array}{l}\text { Data from Evaluation of Potential Agglomeration of KW Container Sludge Simulant } \\
\text { and 50/50 Uranium Oxide Mixture U(IV)/U(VI) with Heating, PNNL-19597, AJ } \\
\text { Schmidt and SI Sinkov, 2010, Pacific Northwest National Laboratory, Richland, } \\
\text { Washington (limited distribution). } \\
\text { (a) Solids settled } 2 \text { days before heating commenced. Due to void formation, the } \\
\text { accuracy of sludge density measurements after heating is approximately } \pm 20 \% \text {. } \\
\text { (b) Control sample; held at room temperature. }\end{array}$} \\
\hline
\end{tabular}

The goal of the XRD analyses was to identify whether dehydration reactions of metaschoepite, goethite, or gibbsite occurred. Quantitative or semi-quantitative interpretations of the XRD analysis results were not attempted for these heterogeneous materials. Instead of using XRD techniques, judgments about changes in the $\mathrm{U}(\mathrm{IV}) \leftrightarrow \mathrm{U}(\mathrm{VI})$ distribution are better made by dissolution of mixed and representative samples of the starting and product sludge solids in sodium sulfate/phosphoric acid solution and spectrophotometric analyses of the resulting solutions. Such analyses were not performed for these scoping tests, which focused on the mechanical properties of the initial and product simulant sludges, but are important for further understanding of hydrothermal and long-term aging reactions in sludge.

\subsubsection{Appearances of $\mathrm{UO}_{2} / \mathrm{UO}_{3} \cdot 2 \mathrm{H}_{2} \mathrm{O}$ and KW Containerized Sludge Simulant Heated at $96^{\circ} \mathrm{C}$}

Observations collected during and after the testing are summarized in Table 3.4. Images from the testing displayed in Figure 3.22 through Figure 3.24 show the cracked and void-filled settled solids present under the supernatant solution.

Agglomeration and void formation were observed within 24 hours at $96^{\circ} \mathrm{C}$ during the testing with the $\mathrm{UO}_{2} / \mathrm{UO}_{3} \cdot 2 \mathrm{H}_{2} \mathrm{O}$ mixture. Also within the first day, a disk of lighter colored (light green/yellow) agglomerates was observed suspended near the top of the water/air interface. When the centrifuge cone was disturbed, the agglomerate settled rapidly to the sludge bed. Based on observations, both the floating of the agglomerate and the formation of voids were caused by gas bubbles. Similar flotation of uranium oxides, including metaschoepite, has been observed because of bubble capture and a high affinity of the solids scum for the air-water interface (Buck et al. 2004). Because the $\mathrm{UO}_{2} / \mathrm{UO}_{3} \cdot 2 \mathrm{H}_{2} \mathrm{O}$ contained no uranium metal, the gas bubbles likely were created when dissolved and entrained air was displaced and separated from the solution. The air, driven from the solution into the gas phase upon heating, expanded when the samples were heated to test temperatures. 
Voids within the simulated KW containerized sludge also formed in Tests S-5 and S-6, although to a smaller extent than in $\mathrm{UO}_{2} / \mathrm{UO}_{3} \cdot 2 \mathrm{H}_{2} \mathrm{O}$ sludge in Tests U-1 and U-2. In Tests S-5 and S-6, an opaque rustbrown and non-settling suspension formed in the supernatant. The color and the non-settling, very finely particulate character of the suspension is consistent with the hematite, $\mathrm{Fe}_{2} \mathrm{O}_{3}$, and goethite, $\mathrm{FeOOH}$, present from the aging of the ferrihydrite component used to prepare the simulant sludge (see Appendix A of Sinkov et al. 2010 for XRD analysis of the ferrihydrite starting material).

Table 3.4. Test Observations from Warm Water Heating

\begin{tabular}{|c|c|c|c|}
\hline Sample & Time & $\begin{array}{c}\text { Temp. } \\
{ }^{\circ} \mathrm{C}\end{array}$ & Observations \\
\hline \multirow[b]{2}{*}{$\mathrm{U}-1^{\text {(a) }}$} & $\sim 24 \mathrm{hr}$ & 96 & $\begin{array}{l}\text { Voids in sludge bed and floating layer } 3 \text { to } 5 \mathrm{~mm} \text { diameter were observed. The floating } \\
\text { layer sank when the cone was disturbed (Figure 3.22a). Accurate volume measurements } \\
\text { are less certain because of the voids. }\end{array}$ \\
\hline & $\sim 96 \mathrm{hr}$ & 96 & $\begin{array}{l}\text { See Figure } 3.23(\mathrm{a}) \text {, (b), and (c). A discontinuous sludge bed with agglomerates and voids } \\
\text { was observed. The oxide mixture exhibits a lavender color. The simulant did not slump } \\
\text { when turned on its side. The upper } \sim 1 \text {-mm solids layer is lighter in color, suggesting } \\
\text { oxidation to U(VI). The top surface of solids supports the weight of a spatula. Consistent } \\
\text { and significant strength with depth was observed as the spatula was pushed into the } \\
\text { simulant. The texture was similar to a hard clay material. Significant resistance was } \\
\text { observed when attempting to rotate/twist the spatula. The centrifuge tube was } \\
\text { aggressively shaken, and a significant population of fines ( }<50 \% \text { of the volume) was } \\
\text { observed. }\end{array}$ \\
\hline \multirow[b]{2}{*}{$\mathrm{U}-2^{(\mathrm{a})}$} & $24 \mathrm{hr}$ & 96 & $\begin{array}{l}\text { Discontinuities and voids were observed (Figure } 3.22 \mathrm{~b} \text { ). Volume measurements are } \\
\text { uncertain with the voids. }\end{array}$ \\
\hline & $\sim 96 \mathrm{hr}$ & 96 & $\begin{array}{l}\text { See Figure 3.23(a), (b), (c), and (d). It was similar in appearance to U-1. The simulant } \\
\text { did not slump. The top surface supported the spatula. Four agglomerate chunks } \\
\text { [Figure 3.23(d)] were isolated and transferred to a weigh boat. Each of these } \\
\text { agglomerates was easily disintegrated to fines by applying low/moderate force with the } \\
\text { spatula. Agglomerate strengths are low, and disintegration by a jet of water is highly } \\
\text { likely. }\end{array}$ \\
\hline $\mathrm{U}-3^{(\mathrm{a})}$ & $1 \mathrm{wk}$ & $\begin{array}{c}\text { Room } \\
\text { temp }\end{array}$ & \multirow{2}{*}{$\begin{array}{l}\text { U-3 and U-4 behaved essentially the same. There was little or no change in settled } \\
\text { volume. Samples slumped when placed on their sides. Sludge layers did not support the } \\
\text { weight of the spatula (i.e., dropped to bottom of tube under spatula weight). Samples } \\
\text { could be suspended by gentle rocking the sample on its side. }\end{array}$} \\
\hline $\mathrm{U}-4^{(\mathrm{a})}$ & $1 \mathrm{wk}$ & $\begin{array}{c}\text { Room } \\
\text { temp }\end{array}$ & \\
\hline S-5 & $96 \mathrm{hr}$ & 96 & \multirow{2}{*}{$\begin{array}{l}\text { S-5 and S-6 behaved essentially the same. See Figure 3.24(a-d). Significant suspended } \\
\text { particulate in overlying supernatant (consistent with appearance of starting ferrihydrite } \\
\text { present as hematite/goethite) was observed. Accurate measurement of the settled solids } \\
\text { volume is not possible. Layering with color differences and voids was observed. The } \\
\text { sample slumped and did not support near-vertical spatula until a layer of sand at the } \\
\text { bottom of the sample was encountered. Gentle rocking resulted in solids suspension. } \\
\text { Very little strength was observed. No agglomerates were observed after gently rocking } \\
\text { the samples. }\end{array}$} \\
\hline S-6 & $96 \mathrm{hr}$ & 96 & \\
\hline
\end{tabular}

(a) U-1, U-2, U-3, and U-4 were prepared on June 11, 2010. The U oxide mixtures were added to 15-mL centrifuge cones, and samples were gently mixed and swirled to promote a level surface upon settling. After several days of settling, the average settled density, before heating, was $1.93 \mathrm{~g} / \mathrm{cm}^{3} \pm 4 \%$. Data from Evaluation of Potential Agglomeration of KW Container Sludge Simulant and 50/50 Uranium Oxide Mixture U(IV)/U(VI) with Heating, PNNL-19597, AJ Schmidt and SI Sinkov, 2010, Pacific Northwest National Laboratory, Richland, Washington (limited distribution). 


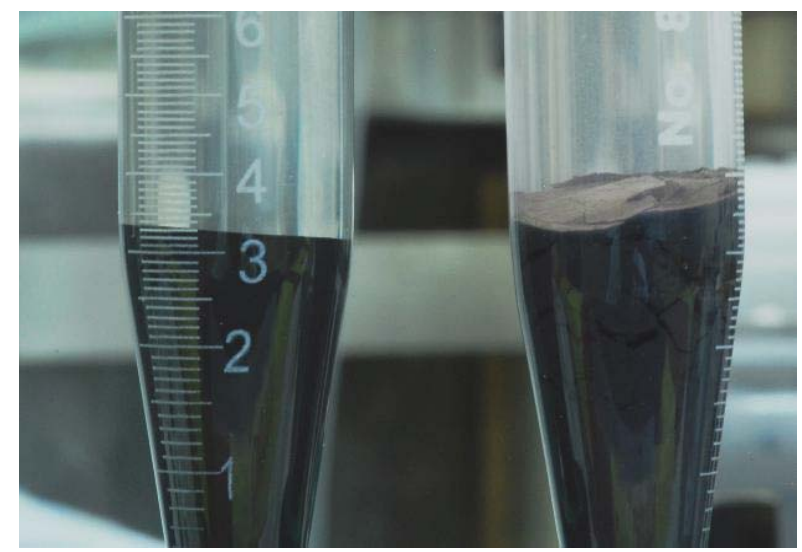

Figure 3.22a.

Left-Test U-3, control held at room temperature Right—-Test U-1 exposed to $96^{\circ} \mathrm{C}$ for $\sim 24 \mathrm{hrs}$.

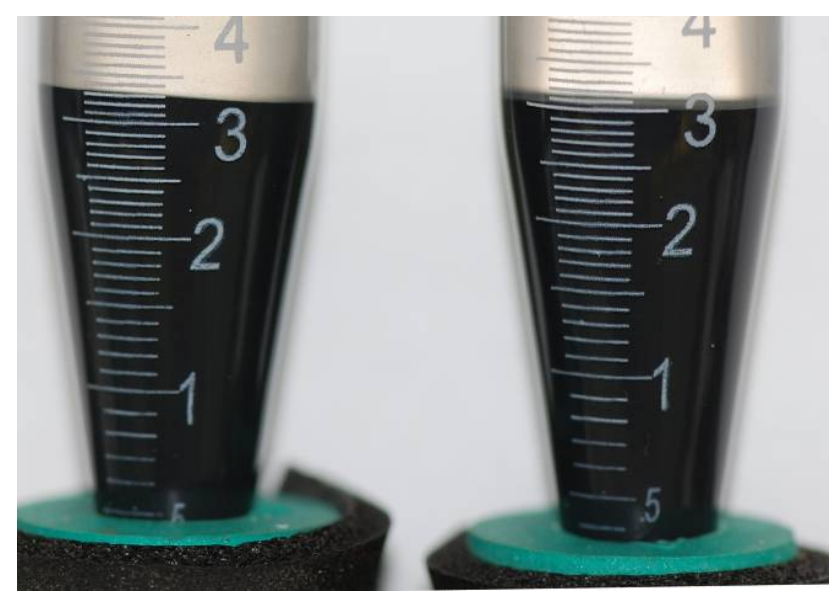

Figure 3.22c.

Left and Right-Tests U-3 and U-4 controls, respectively, held at room temperature for 1 week.

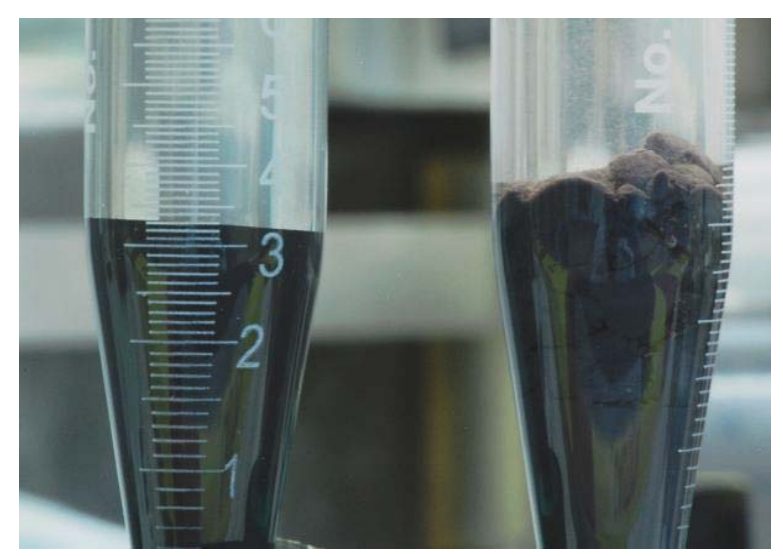

Figure 3.22b.

Left-Test U-3, control held at room temperature Right-Test U-2 exposed to $96^{\circ} \mathrm{C}$ for $\sim 24 \mathrm{hrs}$.

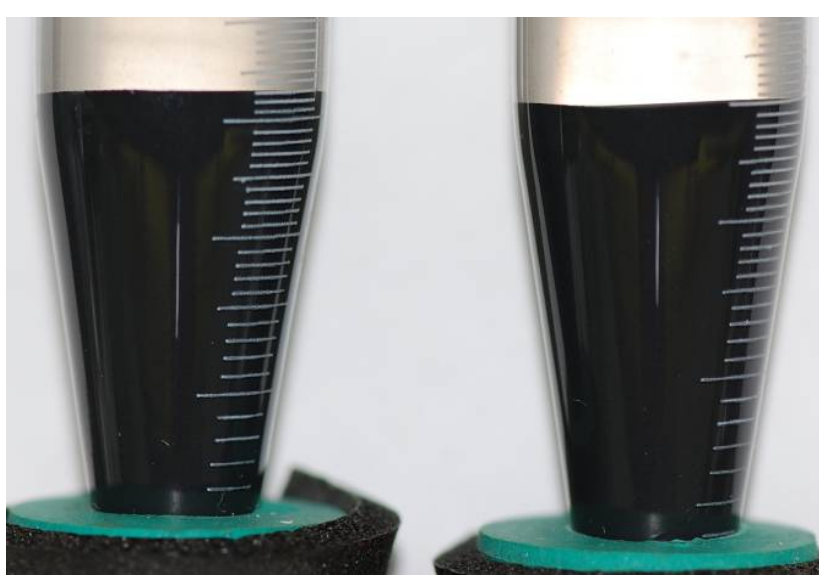

Figure 3.22d.

Left and Right - Tests U-3 and U-4 controls, respectively, held at room temperature for 1 week in rotated views.

Figure 3.22. $50: 50$ (mole basis) Mixtures of $\mathrm{UO}_{2}: \mathrm{UO}_{3} \cdot 2 \mathrm{H}_{2} \mathrm{O}$. Tests $\mathrm{U}-1$ and $\mathrm{U}-2$, Exposed to $96^{\circ} \mathrm{C}$ for 24 hours, and Control Tests U-3 and U-4, Held at Room Temperature.

After completion of the heating, the samples were allowed to cool, and post-test observations were made. Two means were used to provide an indication of strength:

1. Slump test-Turn the test vessel on its side and observe if the sludge bed begins to flow/slump.

2. Strength test - Stand an $\sim 6.0$-gram mass spatula $(\sim 14 \mathrm{~cm}$ long and similar to the image shown in Figure 2.1) vertically on its end. Determine if the structure of the sludge beds provides sufficient strength to support the spatula.

For the control $\mathrm{UO}_{2} / \mathrm{UO}_{3} \cdot 2 \mathrm{H}_{2} \mathrm{O}$ Tests U-3 and U-4 and heated $\mathrm{KW}$ containerized simulant Tests $\mathrm{S}-5$ and S-6, the solid materials slumped and did not support the spatula mass. For Tests S-5 and S-6, some resistance was encountered when the spatula contacted the sand, a component of the simulant, which, by 
touch, had apparently and expectedly settled to the bottom. For these four tests, gentle rocking of the centrifuge cone resulted in sample suspension and mobilization.

In contrast, the heated Tests U-1 and U-2 did not slump, and the solids surface exhibited sufficient strength to support the spatula. Additional resistance was observed when the spatula was pushed into the sludge. The resistance was consistent at all depths, indicating that the entire sample had agglomerated homogeneously rather than form a surface crust that was harder than the underlying material. After probing, sample U-1 was aggressively agitated by shaking for about 10 seconds. This agitation eroded and suspended the fines. Later observations indicated that as much as $50 \%$ of the sample may have been dispersed by the agitation.

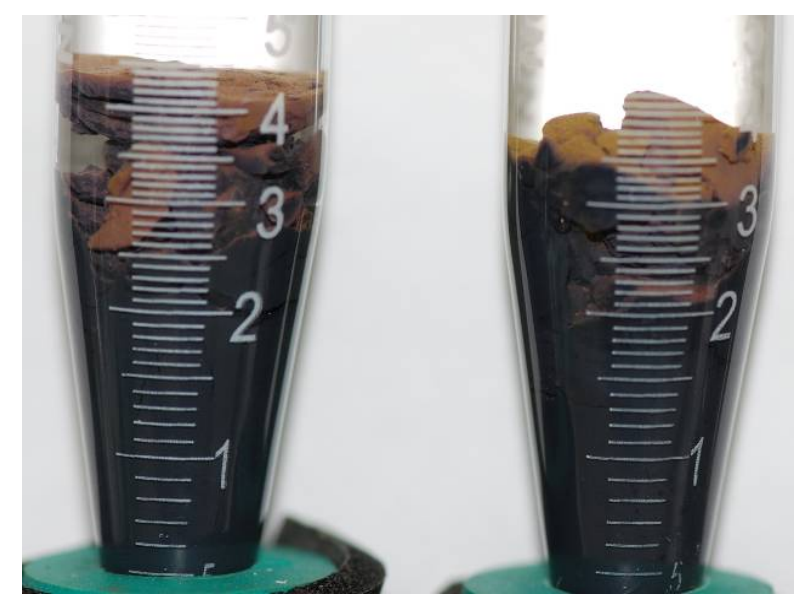

Figure 3.23a.

Left and Right-Tests U-1 and U-2, respectively, exposed to $96^{\circ} \mathrm{C}$ for 96 hours.

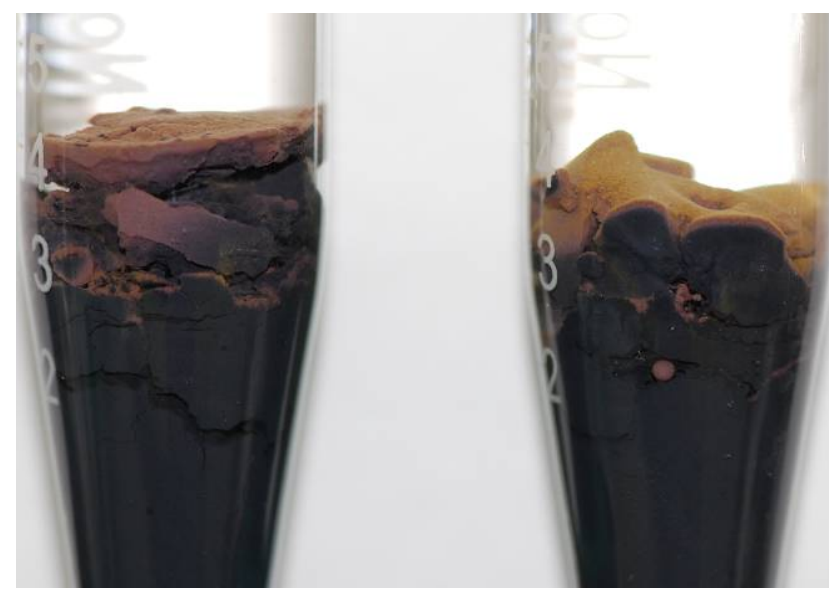

Figure 3.23c.

Left and Right-Rotated views compared with Figure 3.23 b of Tests U-1 and U-2, respectively, exposed to $96^{\circ} \mathrm{C}$ for 96 hours.

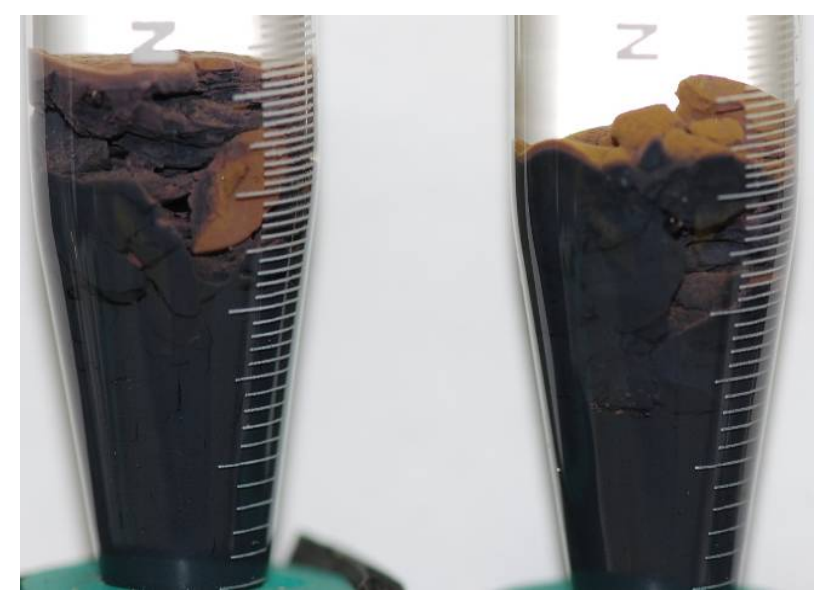

Figure 3.23b.

Left and Right—-Rotated views compared with Figure 3.23a of Tests U-1 and U-2, respectively, exposed to $96^{\circ} \mathrm{C}$ for 96 hours.

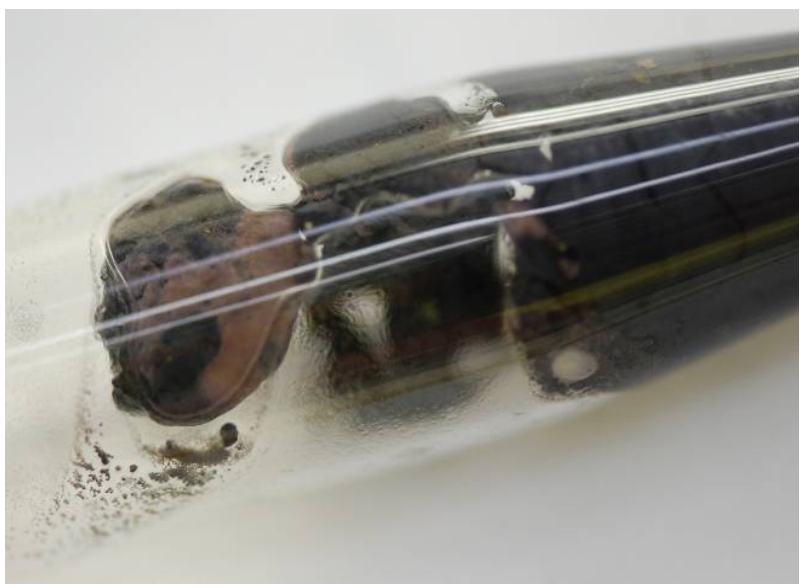

Figure 3.23d.

View of agglomerate from Tests U-2 exposed to $96^{\circ} \mathrm{C}$ for 96 hours.

Figure 3.23. Test U-1 and U-2 50:50 (mole basis) $\mathrm{UO}_{2}: \mathrm{UO}_{3} \cdot 2 \mathrm{H}_{2} \mathrm{O}$ Mixtures Exposed to $96^{\circ} \mathrm{C}$ for 96 Hours 


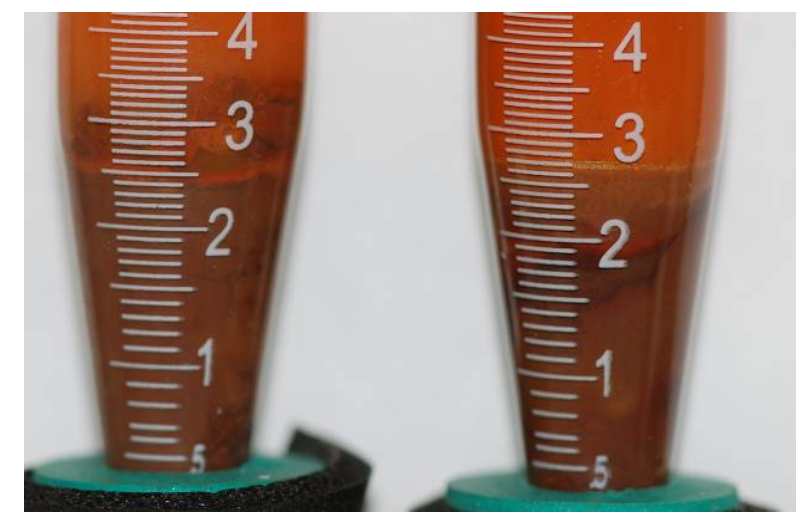

Figure 3.24a.

Left and Right - Tests S-5 and S-6, respectively, exposed to $96^{\circ} \mathrm{C}$ for 96 hours.

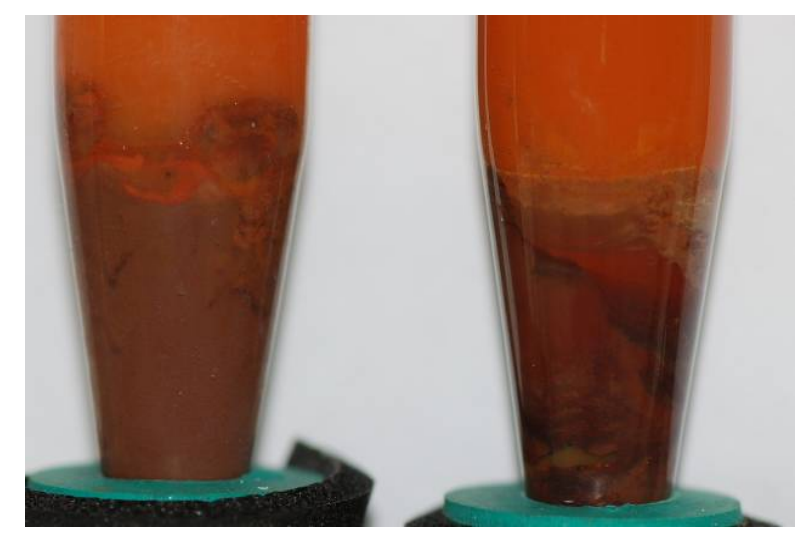

Figure 3.24c.

Left and Right - Rotated views compared with Figure 3.24b of Tests S-5 and S-6, respectively, exposed to $96^{\circ} \mathrm{C}$ for 96 hours.

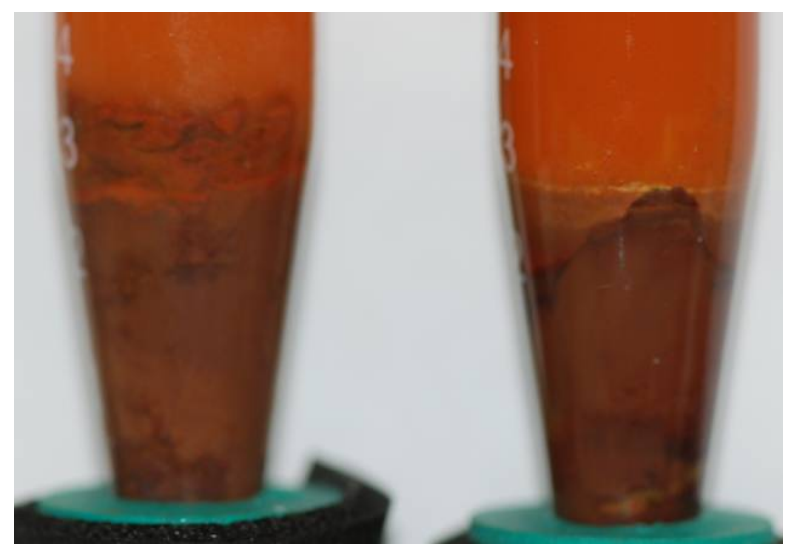

Figure 3.24b.

Left and Right-Rotated views compared with Figure 3.24a of Tests S-5 and S-6, respectively, exposed to $96^{\circ} \mathrm{C}$ for 96 hours.

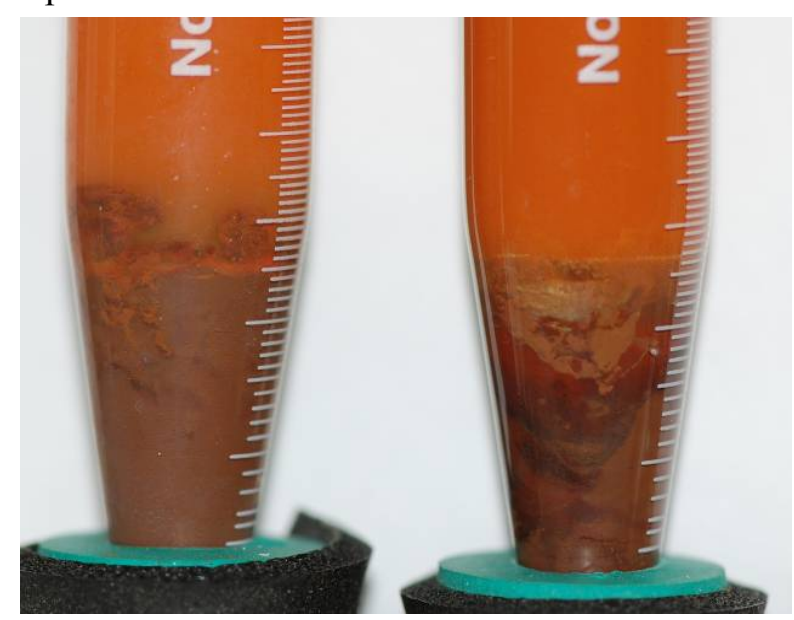

\section{Figure 3.24d.}

Left and Right - Rotated views compared with Figure 3.24c of Tests S-5 and S-6, respectively, exposed to $96^{\circ} \mathrm{C}$ for 96 hours.

Figure 3.24. KW Sludge Simulant after 96 Hours of Exposure to $96^{\circ} \mathrm{C}$. Figures show views of Tests S-5 and S- 6 with samples being rotated $90^{\circ}$ in each sequential image.

After initial probing of Test U-2, four agglomerates, each roughly 4 to $5 \mathrm{~mm}$ in length, were isolated and individually evaluated for strength. Each of these agglomerates was easily disintegrated with mild force applied by the spatula.

\subsection{Shear-Strength Measurements}

The shear strength is defined as the maximum stress force that can be applied to a material before it deforms. As such, K Basin sludge shear strength becomes an important attribute to predict the ease of sludge remobilization during retrieval. Materials that possess shear strength are typically solid/liquid mixtures that have solid-like behavior at low stress and fluid-like behavior at high stress. During the 
solid-like behavior, the material behaves elastically such that when the stress is removed, the material returns to its initial state. Stress above the shear-strength threshold irreversibly deforms the material to initiate fluid-like behavior. The shear strength thus is regarded as the transition between elastic behavior and viscous flow.

During preparation and manipulation of $\mathrm{UO}_{2} / \mathrm{UO}_{3} \cdot 2 \mathrm{H}_{2} \mathrm{O}$ mixtures as described in Section 2.1.1, compositions near $50 \% / 50 \% \mathrm{UO}_{2} / \mathrm{UO}_{3} \cdot 2 \mathrm{H}_{2} \mathrm{O}$ were noted to be much more difficult to stir and suspend than mixtures at other compositions. The composition of settler tank sludge is expected to be dominated by mixtures of $\mathrm{UO}_{2}$ and $\mathrm{UO}_{3} \cdot 2 \mathrm{H}_{2} \mathrm{O}$ because the sludge originated from cleaning operations for irradiated metallic uranium $\mathrm{N}$ Reactor fuel. Based on observations of hardpans or layers during sludge sample retrieval operations in the KE and KW Basins, sludge materials of other compositions also may attain high strengths that could challenge retrieval and handling steps in processing. Therefore, strength measurements are part of current genuine sludge characterization activities. The strengths of various ratios of $\mathrm{UO}_{2}$ and $\mathrm{UO}_{3} \cdot 2 \mathrm{H}_{2} \mathrm{O}$, which may mimic the expected compositions of settler sludge, and the strength of a KW containerized simulant sludge, whose compositions are given in Table 2.1, were measured to determine the range of shear strengths that actual sludge might attain and to attempt to correlate shear strength with sludge composition.

The shear strength properties of $\mathrm{UO}_{2} / \mathrm{UO}_{3} \cdot 2 \mathrm{H}_{2} \mathrm{O}$ mixtures are described in Section 3.3.1, and the densities and material distributions of the $\mathrm{UO}_{2}, \mathrm{UO}_{3} \cdot 2 \mathrm{H}_{2} \mathrm{O}$, and water mixtures are given in Section 3.3.2. The shear-strength properties of the KW containerized sludge simulant are described in Section 3.3.3. Some information on the shear strengths of actual sludge is given in Section 3.3.4.

\subsubsection{Shear Strengths of $\mathrm{UO}_{2} / \mathrm{UO}_{3} \cdot 2 \mathrm{H}_{2} \mathrm{O}$ Mixtures}

As part of the simulated sludge-strength testing, $\mathrm{UO}_{2} / \mathrm{UO}_{3} \cdot 2 \mathrm{H}_{2} \mathrm{O}$ mixtures of $100 \% / 0 \%, 49 \% / 51 \%$, and $35 \% / 65 \%$ (mole basis) composition were placed into $120-\mathrm{mL}$ jars ( $\sim 45 \mathrm{~mm}$ inner diameter), capped tightly to prevent further oxidation, and allowed to settle undisturbed for $\sim 3 \frac{1}{2}$ months. In February 2010 , a series of shear-strength measurements were made under TI 53451-TI22. The initial measurement was of the $49 \% / 51 \% \mathrm{UO}_{2} / \mathrm{UO}_{3} \cdot 2 \mathrm{H}_{2} \mathrm{O}$ mixture, done on 5 February 2010 . The maximum instrument torque was exceeded, indicating that the shear strength was greater than $26,680 \mathrm{~Pa}$ (Table 3.5). In the process of extracting the shear vane from the settled solids, the sample was disturbed. The contents were partially mixed, and the sample strength was re-measured after 3 days of settling. The strength was lower but still ranged from 3800 to $16,000 \mathrm{~Pa}$. In contrast, and in accordance with previous qualitative observations, the other two uranium oxide mixtures also measured on 8 February 2010 had significantly lower shear strengths. The $100 \% \mathrm{UO}_{2}$ shear strength ranged from 350 to $430 \mathrm{~Pa}$ while the $35 \% / 65 \% \mathrm{UO}_{2} / \mathrm{UO}_{3} \cdot 2 \mathrm{H}_{2} \mathrm{O}$ mixture strength ranged from 77 to $100 \mathrm{~Pa}$.

Tests were run to determine if the sample shear strength would change by settling after aggressive mixing. Accordingly, the $100 \% \mathrm{UO}_{2}, 49 \% / 51 \% \mathrm{UO}_{2} / \mathrm{UO}_{3} \cdot 2 \mathrm{H}_{2} \mathrm{O}$, and the $35 \% / 65 \% \mathrm{UO}_{2} / \mathrm{UO}_{3} \cdot 2 \mathrm{H}_{2} \mathrm{O}$ samples were manually mixed with a metal spatula for about 5 minutes. Despite best efforts, the $49 \% / 51 \% \mathrm{UO}_{2} / \mathrm{UO}_{3} \cdot 2 \mathrm{H}_{2} \mathrm{O}$ mixture could not be completely homogenized with the spatula such that, after mixing, the sample still was lumpy but with other well-mixed portions. The $100 \% \mathrm{UO}_{2}$ and the $35 \% / 65 \%$ $\mathrm{UO}_{2} / \mathrm{UO}_{3} \cdot 2 \mathrm{H}_{2} \mathrm{O}$ mixed well. A layer of water was added to the top of the containers to minimize dry-out during the extended settling periods inside the fume hood. Shear-strength measurements were collected on 17 March 2010 following 5 weeks of undisturbed settling. The samples were aggressively mixed 
again following the March 2010 measurements and re-measured on 2 August 2010 after 138 days or $\sim 4 \frac{1}{2}$ months of undisturbed settling.

Sealing of the $49 \% / 51 \% \mathrm{UO}_{2} / \mathrm{UO}_{3} \cdot 2 \mathrm{H}_{2} \mathrm{O}$ container was not air tight over the settling interval from February to March 2010, and the overlying water evaporated such that the top of the sample formed a very thin skin. A small fracture through the center also was observed in the March 2010 measurements. Even with the water loss, the 1600 to $2000 \mathrm{~Pa}$ shear strength for the partially dried $49 \% / 51 \%$ $\mathrm{UO}_{2} / \mathrm{UO}_{3} \cdot 2 \mathrm{H}_{2} \mathrm{O}$ mixture after 5 weeks was only slightly higher than the 980 to $1700 \mathrm{~Pa}$ values obtained at 3 -days settling time. Water was observed seeping out of the sample when the vane was inserted $\sim 32 \mathrm{~mm}$ further down, suggesting that pockets of water were trapped within the sample. Nevertheless, the strengths observed after stirring and settling were much lower than the $>27,000$ Pa value initially registered for this sample and even the 3800 to $16,000 \mathrm{~Pa}$ values for the disturbed materials 3 days after the initial measurement. The strength observed after the subsequent 138 days of settling was $2200 \mathrm{~Pa}$, slightly more than observed after 5 weeks of settling but, again, not as great as the initial values.

Table 3.5. Shear Strengths of $\mathrm{UO}_{2} / \mathrm{UO}_{3} \cdot 2 \mathrm{H}_{2} \mathrm{O}$ Mixtures and Simulated KW Containerized Sludge

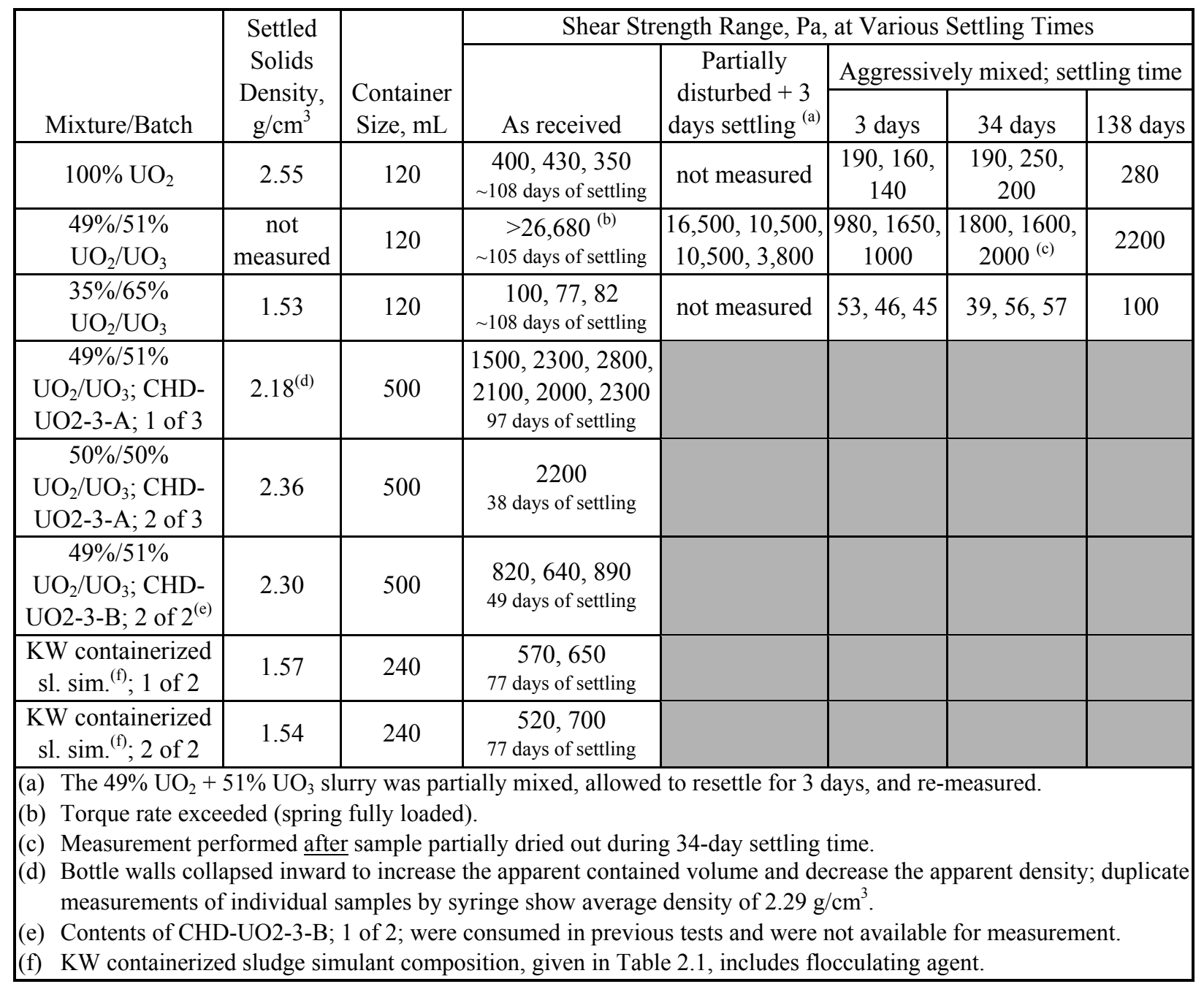


After 5 weeks of settling, the $100 \% \mathrm{UO}_{2}$ sample had a well defined settled layer and also had slightly higher shear strengths (187 to $250 \mathrm{~Pa}$ ) than at the 3-day settling time (140 to $190 \mathrm{~Pa}$ ) but lower than the initial measurement values obtained in February (350 to $430 \mathrm{~Pa}$ ). The strength after 138 days of subsequent settling was $280 \mathrm{~Pa}$, again slightly greater than the values after 5 weeks of settling but not as great as the initial measurement.

Like the $100 \% \mathrm{UO}_{2}$ sample, the $35 / 65 \% \mathrm{UO}_{2} / \mathrm{UO}_{3} \cdot 2 \mathrm{H}_{2} \mathrm{O}$ also had a well defined settled layer. The $35 / 65 \% \mathrm{UO}_{2} / \mathrm{UO}_{3} \cdot 2 \mathrm{H}_{2} \mathrm{O}$ had 45 - to $53-\mathrm{Pa}$ shear strengths after 5 weeks of settling that were similar to the 39- to 55-Pa strengths after 3 days of settling but, again, lower than the initial 80- to 100-Pa shear strengths found in February. The strength after 138 days of settling, $100 \mathrm{~Pa}$, was greater than the values at 5 weeks and comparable to the initially measured shear strengths.

Three portions of equimolar $\mathrm{UO}_{2} / \mathrm{UO}_{3} \cdot 2 \mathrm{H}_{2} \mathrm{O}$, prepared for use in sludge simulants and held in 500-mL bottles, also were measured for shear strength. These three items had settling times of 38, 49, and 97 days. The observed respective shear strengths were $2200 \mathrm{~Pa}, 640$ to $890 \mathrm{~Pa}$, and 1500 to $2800 \mathrm{~Pa}$. Except for the material that had settled for 49 days having 640- to 890-Pa shear strength, the strengths were consistent with the 980- to 2200-Pa strengths observed for the older mixed and settled $49 \% / 51 \%$ $\mathrm{UO}_{2} / \mathrm{UO}_{3} \cdot 2 \mathrm{H}_{2} \mathrm{O}$ held in a $120-\mathrm{mL}$ jar. These strengths, however, remain much less than the $>26,680-\mathrm{Pa}$ strength found for the $49 \% / 51 \% \mathrm{UO}_{2} / \mathrm{UO}_{3} \cdot 2 \mathrm{H}_{2} \mathrm{O}$ settled for 105 days in a $120-\mathrm{mL}$ jar. The reason for the uncommonly high strength of this latter item is not known.

\subsubsection{Densities and Volume Fractions of $\mathrm{UO}_{2} / \mathrm{UO}_{3} \cdot 2 \mathrm{H}_{2} \mathrm{O} / \mathrm{H}_{2} \mathrm{O}$ Mixtures}

The settled solids densities of the aqueous $\mathrm{UO}_{2} / \mathrm{UO}_{3} \cdot 2 \mathrm{H}_{2} \mathrm{O}$ mixtures tested for shear strength are shown in Table 3.5. Based on 1) the settled densities, 2) the relative molar amounts of $\mathrm{UO}_{2}$ and $\mathrm{UO}_{3} \cdot 2 \mathrm{H}_{2} \mathrm{O}$ as determined by spectrophotometric measurements of the dissolved solids, and 3 ) the assumption that only three phases, all of known density, are present, the volume fraction solids in the wet settled $\mathrm{UO}_{2} / \mathrm{UO}_{3} \cdot 2 \mathrm{H}_{2} \mathrm{O}$ mixtures can be determined. The three phases are water with density of $0.997 \mathrm{~g} / \mathrm{cm}^{3}$ at room temperature, $\mathrm{UO}_{2}$ with density of $10.964 \mathrm{~g} / \mathrm{cm}^{3}$, and $\mathrm{UO}_{3} \cdot 2 \mathrm{H}_{2} \mathrm{O}$ with a density of $5.00 \mathrm{~g} / \mathrm{cm}^{3}$.

The particle densities of the combined $\mathrm{UO}_{2}$ and $\mathrm{UO}_{3} \cdot 2 \mathrm{H}_{2} \mathrm{O}$ solids at various mole fractions of $\mathrm{UO}_{2}$ and $\mathrm{UO}_{3} \cdot 2 \mathrm{H}_{2} \mathrm{O}$ are calculated by the following equation based on the $\mathrm{UO}_{2}$ molecular weight of $270.02 \mathrm{~g}$ and $\mathrm{UO}_{3} \cdot 2 \mathrm{H}_{2} \mathrm{O}$ molecular weight of $322.06 \mathrm{~g}$ :

$$
\begin{aligned}
& \text { Density of dry solids }=\frac{\text { Wt. }\left(\mathrm{UO}_{2}+\mathrm{UO}_{3} \cdot 2 \mathrm{H}_{2} \mathrm{O}\right)}{\text { Volume }\left(\mathrm{UO}_{2}+\mathrm{UO}_{3} \cdot 2 \mathrm{H}_{2} \mathrm{O}\right)}= \\
& =\frac{\mathrm{Mol} \mathrm{Fr} \mathrm{UO}_{2} \times \frac{270.03 \mathrm{~g}}{\mathrm{~mole}}+\mathrm{Mol} \mathrm{Fr} \mathrm{UO}_{3} \cdot 2 \mathrm{H}_{2} \mathrm{O} \times \frac{322.06 \mathrm{~g}}{\mathrm{~mole}}}{\mathrm{Mol} \mathrm{Fr} \mathrm{UO}} \times \frac{270.03 \mathrm{~g}}{\mathrm{~mol}} \times \frac{\mathrm{cm}^{3}}{10.964 \mathrm{~g}}+\mathrm{Mol} \mathrm{Fr} \mathrm{\textrm {UO } _ { 3 } \cdot 2 \mathrm { H } _ { 2 } \mathrm { O } \times \frac { 3 2 2 . 0 6 \mathrm { g } } { \mathrm { mole } } \times \frac { \mathrm { cm } ^ { 3 } } { 5 . 0 0 \mathrm { g } }}
\end{aligned}
$$


The composite dry solids density, the wet settled solids density, and the density of water then can be used to calculate the volume fraction of water: ${ }^{\text {(a) }}$

$$
\text { Volume Fraction Water }=\frac{(\text { Density of dry solids }- \text { density of slurry })}{(\text { Density of dry solids }- \text { density of water })}
$$

The volume fractions of $\mathrm{UO}_{2}$ in $\mathrm{UO}_{2} / \mathrm{UO}_{3} \cdot 2 \mathrm{H}_{2} \mathrm{O}$ /water mixtures are calculated as follows:

Volume Fraction $\mathrm{UO}_{2}=$

$$
=(1-\text { Volume Fraction Water }) \times \frac{\mathrm{Mol} \mathrm{Fr} \mathrm{UO}_{2} \times \frac{270.03 \mathrm{~g}}{\mathrm{~mole}} \times \frac{\mathrm{cm}^{3}}{10.964 \mathrm{~g}}}{\mathrm{Mol} \mathrm{Fr} \mathrm{UO}_{2} \times \frac{270.03 \mathrm{~g}}{\mathrm{~mole}} \times \frac{\mathrm{cm}^{3}}{10.964 \mathrm{~g}}+\mathrm{Mol} \mathrm{Fr} \mathrm{UO}_{3} \cdot 2 \mathrm{H}_{2} \mathrm{O} \times \frac{322.06 \mathrm{~g}}{\mathrm{~mole}} \times \frac{\mathrm{cm}^{3}}{5.00 \mathrm{~g}}}
$$

The volume fractions of $\mathrm{UO}_{3} \cdot 2 \mathrm{H}_{2} \mathrm{O}$ are calculated analogously. The volume fractions of $\mathrm{UO}_{2}$ with respect to the combined $\mathrm{UO}_{2}$ and $\mathrm{UO}_{3} \cdot 2 \mathrm{H}_{2} \mathrm{O}$ solids also are calculated.

The volume fractions of water, $\mathrm{UO}_{2}$, and $\mathrm{UO}_{3} \cdot 2 \mathrm{H}_{2} \mathrm{O}$ as well as the volume fraction of $\mathrm{UO}_{2}$ with respect to the total solids are shown in Table 3.6 and are based on the measurements made in the $\mathrm{UO}_{2} / \mathrm{UO}_{3} \cdot 2 \mathrm{H}_{2} \mathrm{O}$ tests from Table 3.5. The measurements of $99.6 \% \mathrm{UO}_{2}$ and $98.4 \% \mathrm{UO}_{3} \cdot 2 \mathrm{H}_{2} \mathrm{O} \sim 10-\mathrm{mL}$ slurries obtained in previous studies (Sinkov et al. 2008) also are included in Table 3.6 with measurements of 2- to $5-\mathrm{mL}$ mixed $\mathrm{UO}_{2} / \mathrm{UO}_{3} \cdot 2 \mathrm{H}_{2} \mathrm{O}$ samples gathered in the room-temperature oxidation of $\mathrm{UO}_{2}$ aqueous slurries by oxygen gas. Images of the latter samples (Figure 3.25) with $0 \%$ to $99.3 \%$ $\mathrm{U}(\mathrm{VI})$ indicate the range of colors observed - very dark olive-brown for $\mathrm{UO}_{2}[0 \% \mathrm{U}(\mathrm{VI})]$, black at $\sim 22 \%$ $\mathrm{U}(\mathrm{VI})$, lavender at $\sim 65-90 \% \mathrm{U}(\mathrm{VI})$, and yellow-green for compositions approaching pure U(VI) in $\mathrm{UO}_{3} \cdot 2 \mathrm{H}_{2} \mathrm{O}$. Settling times for all tests in Table 3.5 ranged from 38 days to 467 days; settled solids volumes ranged from $2 \mathrm{~mL}$ to $335 \mathrm{~mL}$.

The settled solids densities and the volume fractions of water for the various $\mathrm{UO}_{2} / \mathrm{UO}_{3} \cdot 2 \mathrm{H}_{2} \mathrm{O} / \mathrm{H}_{2} \mathrm{O}$ mixtures are plotted in Figure 3.26. It is seen that settling times and settled-solids volumes had little influence on density or volume fraction of water below about $65 \% \mathrm{U}(\mathrm{VI})$ but that additional settling time increased settled-solids densities at $>65 \% \mathrm{U}(\mathrm{VI})$. And even though slurries with higher metaschoepite fractions consolidated with extended (>14-month) settling time, mechanical slump testing and probing with a spatula after this settling showed that the solids were very weak. Unlike the metaschoepite crust

(a) The equation for the Volume Fraction Water is derived by noting that:

- Volume Fraction Solids + Volume Fraction Water = 1; or, Volume Fraction Solids = 1 - Volume Fraction Water.

- Density of slurry $=$ Volume Fraction Solids $\times$ Density of dry solids + Volume Fraction Water $\times$ Density of water. Substituting and rearranging leads to the final expression for the Volume Fraction Water:

- Density of slurry $=(1-$ Volume Fraction Water $) \times$ Density of dry solids + Volume Fraction Water $\times$ Density of water $=$ Density of dry solids - Volume Fraction Water $\times$ Density of dry solids + Volume Fraction Water $\times$ Density of water.

- Density of slurry - Density of dry solids = Volume Fraction Water $\times$ (Density of water - Density of dry solids).

- Volume Fraction Water $=\frac{(\text { Density of slurry }- \text { Density of dry solids })}{(\text { Density of water }- \text { Density of dry solids })}=\frac{(\text { Density of dry solids }- \text { Density of slurry })}{(\text { Density of dry solids }- \text { Density of water })}$. 
exhibited in the static oxidation of $\mathrm{UO}_{2}$ by oxygenated water at $51{ }^{\circ} \mathrm{C}$ (Section 3.1 .1 ), the uranium oxide particles showed negligible adhesion to each other (agglomeration) and, instead, behaved like fine sand.

Table 3.6. Volume Fractions of Water, $\mathrm{UO}_{2}$, and $\mathrm{UO}_{3} \cdot 2 \mathrm{H}_{2} \mathrm{O}$ in Uranium Oxide Slurries

\begin{tabular}{|c|c|c|c|c|c|c|c|c|}
\hline \multirow[b]{2}{*}{ Slurry Mixture } & \multirow{2}{*}{$\begin{array}{c}\text { Settling } \\
\text { Time, } \\
\text { days }\end{array}$} & \multirow{2}{*}{$\begin{array}{c}\text { Solids } \\
\text { Vol., } \\
\text { mL }\end{array}$} & \multirow{2}{*}{$\begin{array}{l}\mathrm{U}(\mathrm{VI}), \\
\text { mole } \% \\
\text { (a) }\end{array}$} & \multirow{2}{*}{$\begin{array}{l}\text { Settled Solids } \\
\text { Density, } \mathrm{g} / \mathrm{cm}^{3}\end{array}$} & \multicolumn{3}{|c|}{ Settled Solids Volume Fraction } & \multirow{2}{*}{$\begin{array}{l}\mathrm{UO}_{2} \text { Vol. } \\
\text { Fraction } \\
\text { in Solids }\end{array}$} \\
\hline & & & & & Water & $\mathrm{UO}_{2}$ & $\mathrm{UO}_{3} \cdot 2 \mathrm{H}_{2} \mathrm{O}$ & \\
\hline $100 \% \mathrm{UO}_{2}$, as-received & 108 & 108 & 0.0 & 2.548 & 0.844 & 0.156 & 0.000 & 1.000 \\
\hline $\mathrm{UO}_{2}$ oxidation sample ${ }^{(\mathrm{b})}$ & 75 & 9.6 & 0.4 & 2.489 & 0.849 & 0.149 & 0.0016 & 0.990 \\
\hline $\mathrm{UO}_{2}$ oxidation sample ${ }^{(\mathrm{c})}$ & 174 & 3.0 & 22.0 & 2.642 & 0.779 & 0.127 & 0.094 & 0.575 \\
\hline $\begin{array}{l}50 \% / 50 \% \mathrm{UO}_{2} / \mathrm{UO}_{3} ; \\
\text { CHD-UO2-3-A; } 2 \text { of } 3\end{array}$ & 38 & 240 & 50.0 & 2.358 & 0.759 & 0.067 & 0.174 & 0.277 \\
\hline $\begin{array}{l}49 \% / 51 \% \mathrm{UO}_{2} / \mathrm{UO}_{3} ; \\
\text { CHD-UO2-3-A; } 1 \text { of } 3\end{array}$ & 97 & $335^{(\mathrm{d})}$ & 51.0 & $2.290^{(\mathrm{d})}$ & 0.769 & 0.062 & 0.169 & 0.269 \\
\hline $\begin{array}{l}49 \% / 51 \% \mathrm{UO}_{2} / \mathrm{UO}_{3} ; \\
\text { CHD-UO2-3-B; } 2 \text { of } 2\end{array}$ & 49 & 330 & 51.0 & 2.304 & 0.767 & 0.063 & 0.171 & 0.269 \\
\hline $35 \% / 65 \% \mathrm{UO}_{2} / \mathrm{UO}_{3}$ & 108 & 98 & 65.2 & 1.529 & 0.894 & 0.018 & 0.088 & 0.170 \\
\hline $\mathrm{UO}_{2}$ oxidation sample $\mathrm{e}^{(\mathrm{c})}$ & 423 & 3.65 & 65.2 & 1.403 & 0.919 & 0.014 & 0.067 & 0.170 \\
\hline $\mathrm{UO}_{2}$ oxidation sample ${ }^{(\mathrm{c})}$ & 467 & 3.90 & 79.0 & 1.448 & 0.901 & 0.0092 & 0.090 & 0.092 \\
\hline $\mathrm{UO}_{2}$ oxidation sample $\mathrm{e}^{(\mathrm{c})}$ & 465 & 5.00 & 88.9 & 1.472 & 0.889 & 0.0051 & 0.106 & 0.046 \\
\hline $\mathrm{UO}_{2}$ oxidation sample $\mathrm{e}^{(\mathrm{c})}$ & 462 & 2.75 & 95.0 & 1.623 & 0.848 & 0.0030 & 0.149 & 0.020 \\
\hline $\mathrm{UO}_{2}$ oxidation sample ${ }^{(\mathrm{c})}$ & 458 & 2.00 & 97.3 & 1.792 & 0.804 & 0.0020 & 0.194 & 0.010 \\
\hline $\mathrm{UO}_{2}$ oxidation sample ${ }^{(\mathrm{b})}$ & 39 & 10.1 & 98.4 & 1.200 & 0.950 & 0.00031 & 0.050 & 0.0062 \\
\hline $\mathrm{UO}_{2}$ oxidation sample $\mathrm{e}^{(\mathrm{c})}$ & 422 & 3.15 & 99.3 & 1.616 & 0.846 & 0.00038 & 0.154 & 0.0025 \\
\hline
\end{tabular}

(a) Spectrophotometric measurements made for all materials except $100 \% \mathrm{UO}_{2}$, as-received.

(b) Data from Table 4.1, Sinkov et al. 2008.

(c) Samples gathered in the preparation of $\mathrm{UO}_{2} / \mathrm{UO}_{3} \cdot 2 \mathrm{H}_{2} \mathrm{O}$ mixtures.

(d) Bottle deformed; density measured using an $\sim 5$-mL syringe sub-sample.

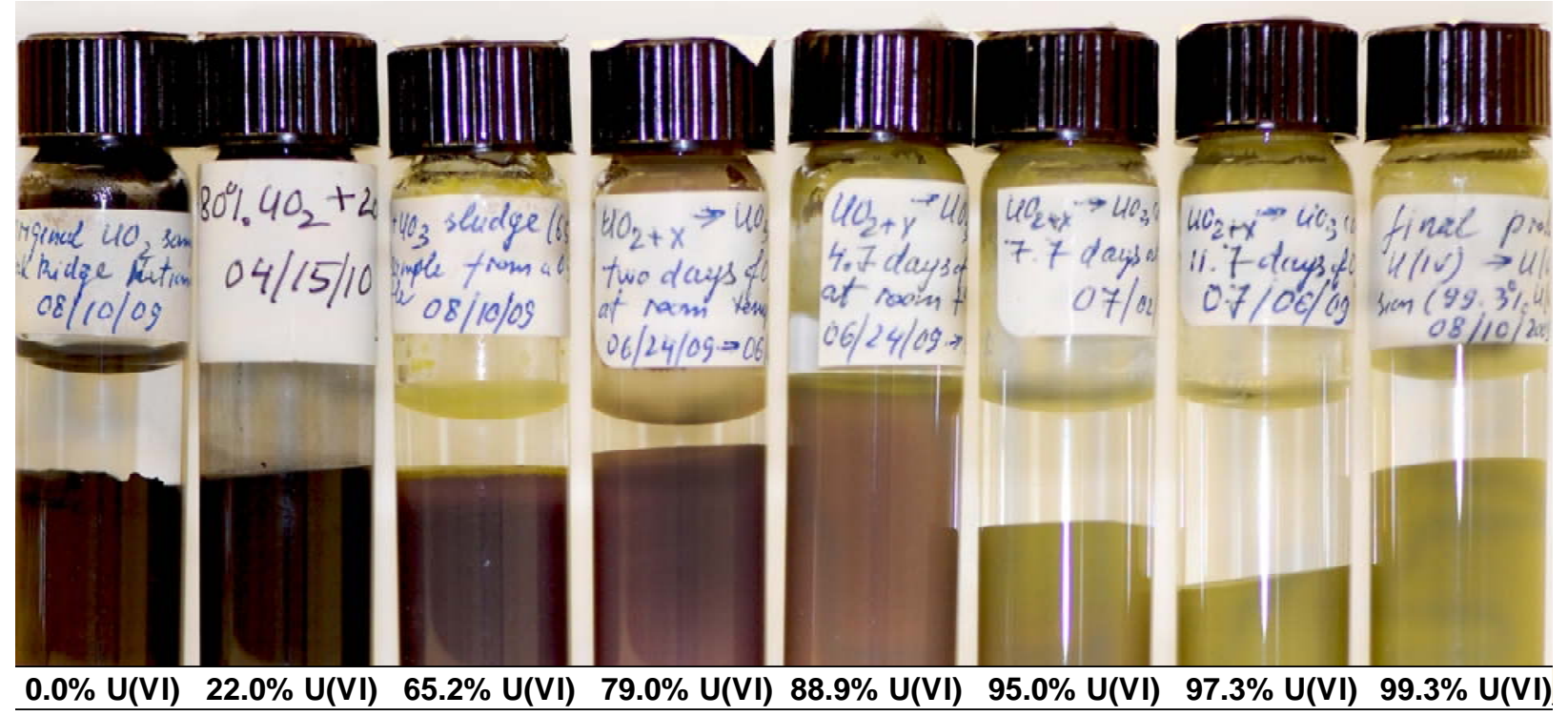

Figure 3.25. $\mathrm{UO}_{2} / \mathrm{UO}_{3} \cdot 2 \mathrm{H}_{2} \mathrm{O}$ Samples From Room-Temperature $\mathrm{UO}_{2}$ Oxidation by Oxygen Gas 


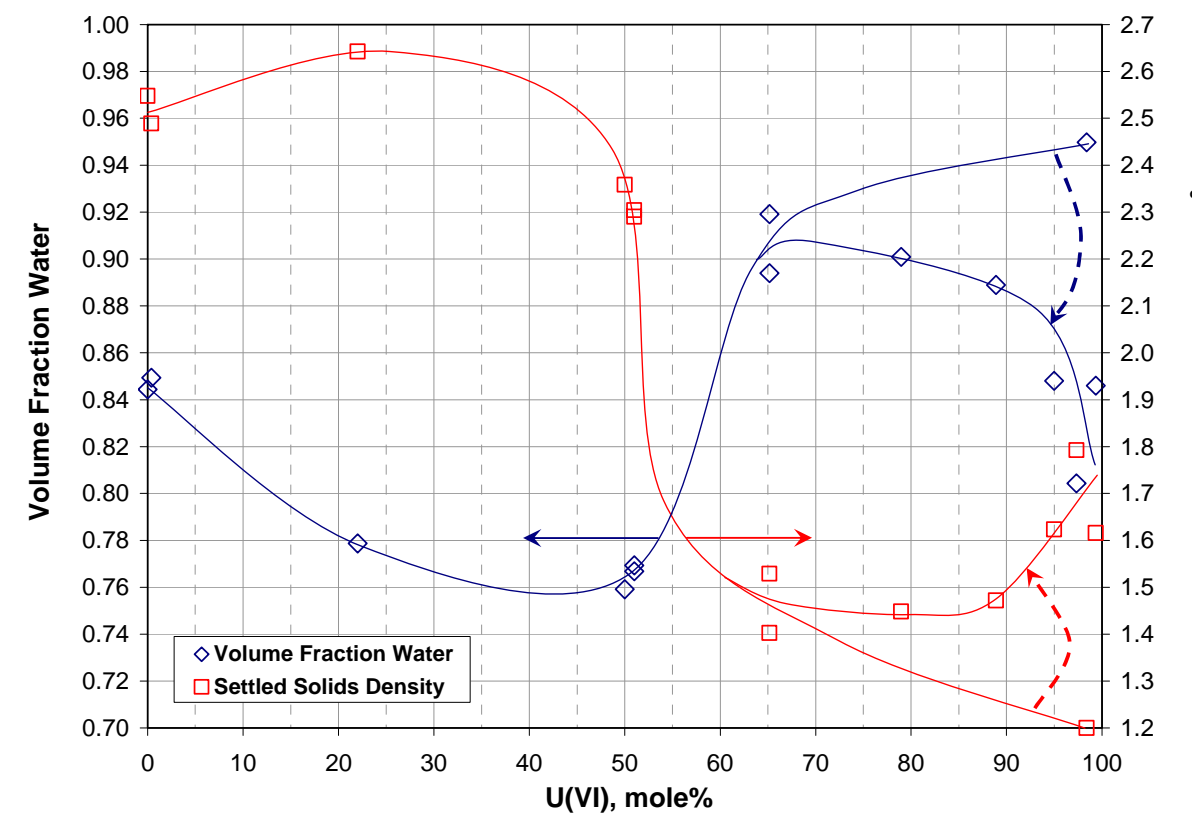

Figure 3.26. Settled $\mathrm{UO}_{2} / \mathrm{UO}_{3} \cdot 2 \mathrm{H}_{2} \mathrm{O}$ Volume Fraction of Water and Density as Functions of U(VI) Content. Dotted arrows indicate volume fraction of water and settled density changes with increasing settling time from 39 days to 14 months.

It is also seen that a minimum volume fraction of water, $\sim 0.76$, is present in $\sim 50 \% / 50 \%$ $\mathrm{UO}_{2} / \mathrm{UO}_{3} \cdot 2 \mathrm{H}_{2} \mathrm{O}$ mixtures. This minimum is significantly lower than the volume-fractions of water of about 0.84 and 0.82 , found, respectively, in the constituent nearly pure $\mathrm{UO}_{2}$ or $\mathrm{UO}_{3} \cdot 2 \mathrm{H}_{2} \mathrm{O}$ settled slurries. Qualitatively, the minimum in volume-fraction of water for the $\sim 50 \% / 50 \%$ mixtures may be understood by recognizing that $\mathrm{UO}_{2}$ has much smaller particle size than $\mathrm{UO}_{3} \cdot 2 \mathrm{H}_{2} \mathrm{O}$ and that, when mixed, these diversely sized particles pack more efficiently than can the individual components. The higher packing density of mixtures is because the small particles can fill the voids left between well-packed larger particles just as sand can fill the space between boulders. The packing density of binary solid size mixtures improves as the relative difference in their particle sizes increases (Zheng et al. 1995). Previous $\mathrm{UO}_{2}$ characterization shows that $\sim 98$ volume $\%$ of the particles is $0.01 \mu \mathrm{m}$ diameter or smaller. Roomtemperature conversion of $\mathrm{UO}_{2}$ to $\mathrm{UO}_{3} \cdot 2 \mathrm{H}_{2} \mathrm{O}$ by dissolved oxygen produces hexagonal plates $\sim 0.1 \mu \mathrm{m}$ thick and 1 to $2 \mu \mathrm{m}$ across as seen by SEM images (Sinkov et al. 2008). Therefore, significant increases in packing density can be realized for blends of $\mathrm{UO}_{2}$ and $\mathrm{UO}_{3} \cdot 2 \mathrm{H}_{2} \mathrm{O}$ compared with the individual $\mathrm{UO}_{2}$ and $\mathrm{UO}_{3} \cdot 2 \mathrm{H}_{2} \mathrm{O}$ components.

The $\mathrm{UO}_{3} \cdot 2 \mathrm{H}_{2} \mathrm{O}$ crystals grow readily by Ostwald ripening (see Section 3.1.1.4) such that $\mathrm{UO}_{3} \cdot 2 \mathrm{H}_{2} \mathrm{O}$ particles found in actual sludge (KC-2/3 M250 from the KE Basin) are up to $5 \mu \mathrm{m}$ wide and $1 \mu \mathrm{m}$ thick due to extended storage under warm $\left(\sim 30\right.$ to $\left.33^{\circ} \mathrm{C}\right)$, moist, and oxic shielded cell conditions (Sinkov et al. 2008).

It is noted that linear decreases in water-volume fraction or increases in solids-volume fraction lead to exponential shear-strength increases in kaolin-water mixtures (Burns et al. 2010) or in non-radioactive KW containerized sludge simulant (Gauglitz et al. 2010). The KW sludge simulant contained ceric oxide, steel grit, $\mathrm{Al}(\mathrm{OH})_{3}$, ferrihydrite, sand, aggregate, and tungsten (Burbank 2009). The lower water fraction or higher solids loading in the $\sim 50 \% / 50 \% \mathrm{UO}_{2} / \mathrm{UO}_{3}$ mixtures compared with the $100 \% \mathrm{UO}_{2}$ and the 
$35 \% / 65 \% \mathrm{UO}_{2} / \mathrm{UO}_{3}$ mixture shown in Figure 3.26 thus help explain the correspondingly higher strengths of the $\sim 50 \% / 50 \% \mathrm{UO}_{2} / \mathrm{UO}_{3}$ mixtures as shown in Table 3.5 .

\subsubsection{Shear Strengths of KW Containerized Sludge Simulant}

Duplicate $\sim 120$-mL portions of KW containerized sludge simulant containing Optimer 7194 Plus flocculating agent were prepared in $250-\mathrm{mL}$ jars for later experimentation by external non-PNNL entities. While awaiting shipment, the simulated sludge samples settled undisturbed for 77 days and then were measured for shear strength. As shown in Table 3.5, the shear strengths of the two portions matched closely and ranged from 520 to $700 \mathrm{~Pa}$.

\subsubsection{Shear Strengths of KE Basin and KW Containerized Sludge}

Westcott and colleagues (2009) have tabulated existing documents and data sources on the K Basin sludge characterizations and evaluations that commenced in 1993. Results from K Basin sludge shearstrength measurements, predominantly from the KE floor, KE pits, and KE canisters from 1995 to 2002, have been summarized (Poloski et al. 2002; Schmidt and Sexton 2009). These measurements were used to establish the shear-strength range of 1 to 8,200 Pa provided in the Sludge Technical Databook (Schmidt 2010). The shear strength is affected by sample history and generally increases with increasing undisturbed settling time. Most of the Poloski and colleague (2002) measurements were obtained from sludge samples that been settled for several days to several weeks. Within this time range, sample shear strengths ranged from less than $100 \mathrm{~Pa}$ to about 3,000 $\mathrm{Pa}$ with the higher shear strengths with the longersettled materials. Shear-strength measurements of these same samples in their as-received state after 20 to 30 days settling showed of $240,4,000,1,000,400$, and 8,200 Pa for samples containing, respectively, $1.7,5,6,17$, and 60 dry basis wt $\%$ uranium (Poloski et al. 2002). The data, therefore, show no clear trend relating shear strength to uranium concentration in the sludge.

Shear strengths were measured for samples collected in 2009 from the KW engineered containers SCS-CON-220, 240, 250, and 260 and passed through 500- $\mu \mathrm{m}$ sieves. ${ }^{(a)}$ The sieved samples were settled for several days to several weeks before measurement. Shear strengths were about 300, 300, and $80 \mathrm{~Pa}$ for samples from SCS-CON-240, 250, and 260, respectively. The total uranium concentrations for the same respective materials were low-4.91, 5.25, and $6.61 \mathrm{wt} \%$ (dry basis). In two separate measurements of low reliability, the shear strength for the settled $<500-\mu \mathrm{m}$ fraction from SCS-CON-220 were $\sim 90 \mathrm{~Pa}$ and $\sim 500 \mathrm{~Pa}$ while the dry-basis uranium concentration was $34.6 \mathrm{wt} \%$. Overall, these recent shear-strength measurements of actual sludge again show no clear trend relating shear strength to uranium concentration.

(a) Fiskum SK, JM Billing, SJ Bos, CA Burns, CD Carlson, DS Coffey, JV Crum, RC Daniel, CH Delegard, MK Edwards, OT Farmer, LR Greenwood, SA Jones, D Neiner, BM Oliver, KN Pool, AJ Schmidt, RW Shimskey, CZ Soderquist, CJ Thompson, ML Thomas, T Trang-Le, and MW Urie. 2009. Characterization Data Package for Containerized Sludge Samples Collected from Engineered Containers SCS-CON-240, 250, 260, and 220. PNNL-19035 (Limited Distribution), Pacific Northwest National Laboratory, Richland, Washington. 


\subsection{Settled-Sludge Expansion Factors}

Volumetric expansion of sludge solids occurs because of chemical reactions such as the corrosion of uranium metal to form $\mathrm{UO}_{2}$ and the subsequent oxidation of $\mathrm{UO}_{2}$ to form $\mathrm{UO}_{3} \cdot 2 \mathrm{H}_{2} \mathrm{O}$. At the same time, little volumetric expansion is expected for other sludge components (e.g., gibbsite, ferrihydrite, sand) as they are largely non-reactive. Based on this knowledge, expansion factors have been developed for use within the STP to account for the postulated increases in solids volume during containerized storage. Expansion factors for various sludge types have been presented in the Sludge Technical Databook (Schmidt 2010). In the theoretical approach used to develop sludge expansion factors, it was conservatively assumed that the volume fraction of water in settled sludge remains constant or increases as sludge constituents oxidize over time.

Among other applications, the expansion factors are used in engineering calculations to determine the volumes of settled sludge that can be loaded into storage containers. However, the conservative assumption that the volume fraction of water remains constant or increases with sludge constituent oxidation could limit the volume of sludge that can be loaded into storage containers, depending upon sludge type, and affect the overall cost of both the Phase 1 and Phase 2 sludge management activities. Key findings from the present uraninite oxidation investigations, along with other relatively recent studies, provide technical bases to re-examine the approach used to calculate the sludge expansion factors. Considerations in this re-examination are discussed in this section.

The STP plans for interim storage of sludge are summarized in Section 4.1. The development of sludge expansion factors that are specified within the Sludge Technical Databook are described in Section 4.2. Section 4.3 reviews results of volumetric changes of sludge samples during a 28-month settling study. Recommendations on the use of results from recent investigations for refining the expansion-factor calculation approach are provided in Section 4.4.

\subsection{Interim Storage of K Basin Sludge}

Under the STP, K Basin sludge disposition will be managed in two phases. The first phase is to retrieve the sludge that currently resides in engineered containers in the KW Basin pool. The retrieved sludge will be hydraulically loaded into STSCs and transported to T Plant for an interim storage period of 10 years or longer (Honeyman and Rourk 2009). To provide shielding and meet transportation requirements, the STSCs will be contained within the Sludge Transport System (STS) cask during STSC loading and transportation. While in T Plant, the STSCs will be stored in cells that are equipped with secondary containment and leak-detection systems. In the second phase of the STP, sludge will be retrieved from interim storage and treated and packaged in preparation for eventual shipment to the WIPP.

Structural details and dimensions of the STSC, which include a removable voided inner annulus, are shown in Figure 4.1 (Johnson 2010). The purpose of the annulus is to enhance heat dissipation. The STSC design capacities with and without the annulus are $2.89 \mathrm{~m}^{3}$ and $3.5 \mathrm{~m}^{3}$, respectively. Under current STP plans, STSCs fitted with the annulus will be used for the more radioactive containerized sludge originating from the settler tanks and currently present in engineered container SCS-CON-230. The improved heat dissipation afforded by the annulus is unnecessary for the lower activity KE and KW 
sludges from the canisters, floors, and pits currently present in the containers SCS-CON-210, 220, 240, 250 , and 260. To maintain the sludge in a water-saturated state, excess water will be loaded into the STSCs during sludge retrieval. Each STSC will contain 0.5 to $2.1 \mathrm{~m}^{3}$ of settled sludge with the specific loading dependent upon sludge type. The loadings thus may be limited by thermal and gas generation rates (e.g., settler sludge) or by volume.

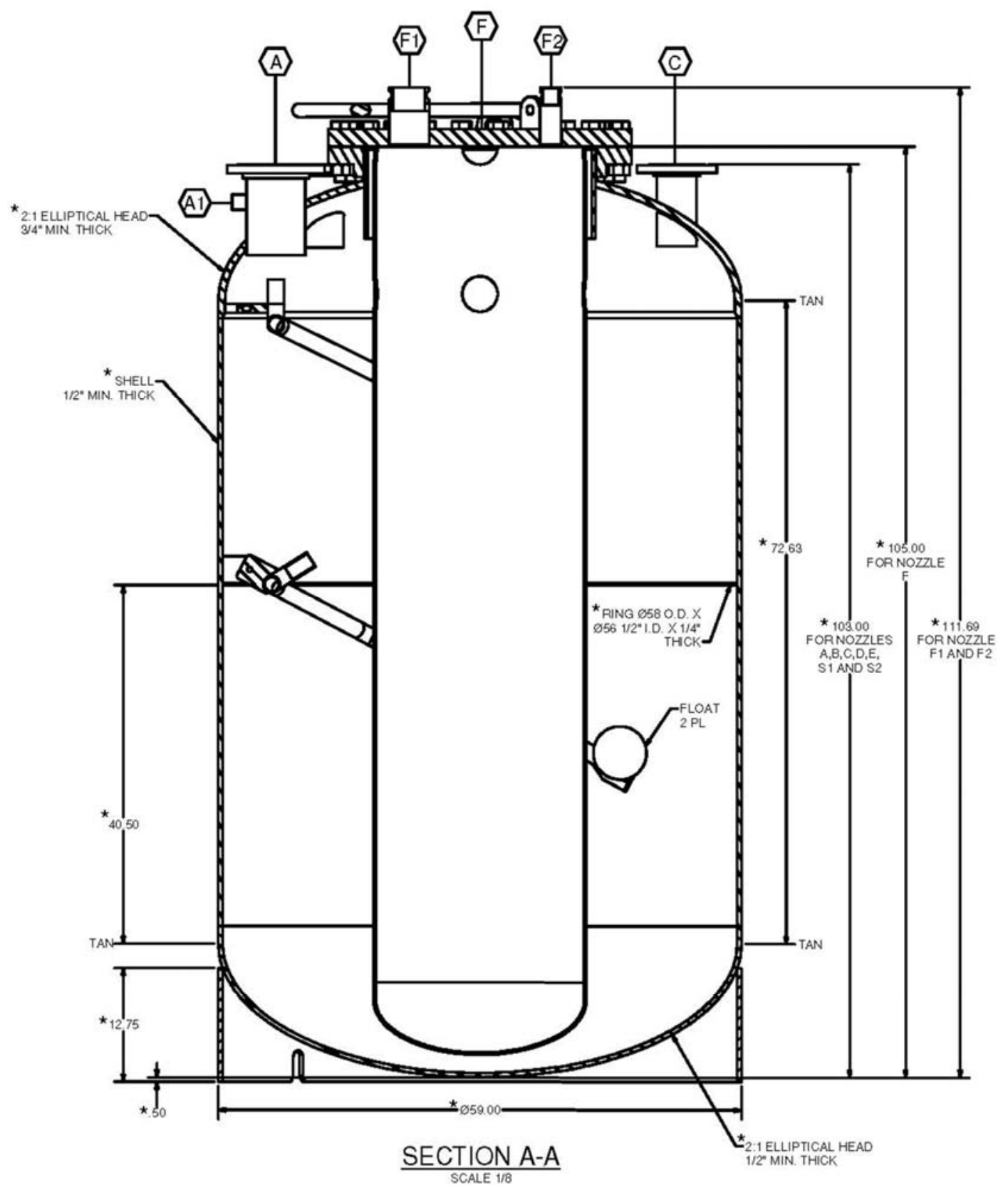

Figure 4.1. STSC Shown with an Inner Annulus. The inner annulus will be used with settler sludge but will be removed for other sludge materials (schematic given in Figure 9 of Johnson [2010]; diagram above reproduced from CHPRC ENGINEERING SKETCH SK-4K-M-002-1R0). 
For shipment to T Plant, the head space of the STSC will communicate with the void space of the STS cask by way of a sintered metal filter, and the atmosphere will be inerted. Upon receipt at T Plant and before unloading the STSC, the STS cask will be vented and purged with nitrogen gas to sweep hydrogen gas accumulations from the airspace to make sure that the lower flammability limits are not exceeded. The cask lid will be remotely removed, and the STSC will be purged with nitrogen gas to make sure that the STSC gas space is lower than the flammability limit. The STSC will be remotely removed from the STS cask, weighed, and lowered into a shielded storage cell using the canyon bridge crane. At this point, the sintered metal filter vent will be removed, and two vent pipes be installed on each STSC. The two vent pipes will be set at different heights to enhance the air exchange rate in the STSC headspace during long-term storage (Johnson 2010).

With time, barometric pressure changes and the differing STSC vent nozzle heights will allow atmospheric oxygen to enter the STSCs, dissolve into the water, and diffuse through the sludge. Radiolytic oxygen and other water radiolysis products (e.g., hydrogen, $\mathrm{H} \cdot$, and peroxyl, $\mathrm{OH}$, radicals and solvated electrons, $\mathrm{e}_{\mathrm{aq}}{ }^{-}$or $\mathrm{H}_{2} \mathrm{O}^{-}$) also will be generated. Therefore, to some extent, dissolved oxygen will be available to inhibit the more rapid anoxic corrosion of uranium metal and abet oxidation of $\mathrm{UO}_{2}$ during storage while penetration of atmospheric oxygen to the settled sludge will be impeded. Overall, with respect to uranium corrosion chemistry, the STSC environment is considered to be semi-oxic.

\subsection{Review of Databook Corrosion-Based Expansion Factors}

The Sludge Technical Databook (Schmidt 2010) includes design and safety basis factors to calculate the volumetric expansion of sludge resulting from expected chemical reactions. During the interim storage of sludge, the particle volume of the sludge solids will increase as uranium metal oxidizes to form uranium dioxide and, during the further oxidation of uranium oxide by dissolved oxygen, to form metaschoepite (see Section 1.0). From these corrosion reactions, two sludge expansion mechanisms occur. The first mechanism is the expansion of the volume of the sludge solids from the generation of corrosion oxidation products that occupy more space than the starting-state sludge. The second sludge expansion mechanism is to increase the bulk sludge volume by retaining hydrogen gas bubbles resulting from uranium corrosion reactions. The technical bases for the development of the sludge expansion factors have been summarized by Schmidt and Sexton (2009) based on detailed analyses advanced by Schmidt and Delegard $(2002,2003)$. The determination of corrosion-based expansion factors is examined in this section.

To calculate sludge expansion from corrosion, it was assumed that only uranium species continue to change oxidation state during storage (Schmidt and Delegard 2003). All other species, including iron and aluminum corrosion products, zirconium cladding, ion exchange material, wind-blown debris, and sand, were assumed to be inert. The oxidation of flocculating agent was not considered previously but may occur. Four sludge types - fuel fragments, KE canister sludge, KW canister sludge, and KE floor sludge - were considered. For each of the four sludge types, the total uranium content was apportioned to specific uranium compounds and metallic uranium to represent the starting-state sludge. Similar uranium compound assignments were established for the sludge anticipated to be present at the end of containerized storage. The controlling chemistry assumptions, including starting-state and ending-state uranium compound assignment, are based on the technical literature and results from characterization of sludge samples, including XRD analysis. 


\subsubsection{Uranium Phase Reactions and Distribution in Sludge}

To assign starting-state uranium compounds, XRD data and interpretations from many high-uraniumcontent $\mathrm{KE}$ canister sludges were examined. Based on these analyses, the samples were judged to contain

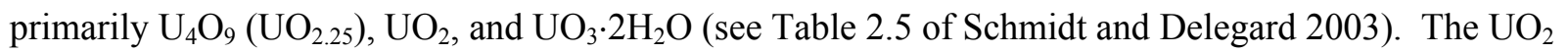
and, at completion, $\mathrm{UO}_{2.25}$, were thought to occur by anoxic corrosion of uranium metal $\left[\mathrm{U}_{(\text {metal }}\right]$ as shown in Reactions 4.1 and 4.2 : $^{(\text {) }}$

$$
\begin{gathered}
\mathrm{U}_{\text {(metal) }}+2 \mathrm{H}_{2} \mathrm{O} \rightarrow \mathrm{UO}_{2}+2 \mathrm{H}_{2} \\
\mathrm{U}_{\text {(metal) }}+2.25 \mathrm{H}_{2} \mathrm{O} \rightarrow \mathrm{UO}_{2.25}+2.25 \mathrm{H}_{2}
\end{gathered}
$$

Oxidation beyond $\mathrm{UO}_{2.25}$ (actually, beyond $\mathrm{UO}_{2}$ ) to form schoepite phases requires oxygen as shown in Reactions 4.3 and 4.4. The schoepites include $\mathrm{UO}_{2.86} \cdot 1.5 \mathrm{H}_{2} \mathrm{O}$, which is not fully oxidized but is $86 \%$ $\mathrm{U}(\mathrm{VI})$ and $14 \% \mathrm{U}(\mathrm{IV})$, and $\mathrm{UO}_{3} \cdot 2 \mathrm{H}_{2} \mathrm{O}$, metaschoepite, which is fully oxidized and $100 \% \mathrm{U}(\mathrm{VI})$ :

$$
\begin{gathered}
\mathrm{UO}_{2.25}+0.305 \mathrm{O}_{2}+1.5 \mathrm{H}_{2} \mathrm{O} \rightarrow \mathrm{UO}_{2.86} \cdot 1.5 \mathrm{H}_{2} \mathrm{O} \\
\mathrm{UO}_{2.25}+0.375 \mathrm{O}_{2}+2 \mathrm{H}_{2} \mathrm{O} \rightarrow \mathrm{UO}_{3} \cdot 2 \mathrm{H}_{2} \mathrm{O}
\end{gathered}
$$

Metaschoepite can undergo subsequent reactions to form other U(VI) phases such as becquerelite, soddyite, and studtite (see Section 1.0).

The water associated with the sludge stored in the STSCs will contain dissolved oxygen and will gain additional oxygen by aeration and radiolytic generation from water. Therefore, $\mathrm{UO}_{2.25}$ will further oxidize and hydrate to an unknown extent in accordance with Reactions 4.3 and 4.4 using the available dissolved and radiolytic oxygen. However, complete conversion of all uranium in the large containers to $\mathrm{UO}_{2.86} \cdot 1.5 \mathrm{H}_{2} \mathrm{O}$ and $\mathrm{UO}_{3} \cdot 2 \mathrm{H}_{2} \mathrm{O}$ is not expected because the oxygen supply to the sludge will be limited by the following conditions:

- Restricted air exchange to the STSC from the T Plant ventilation system

- Oxygen consumption by non-uranium species in the sludge, such as chemically reduced radiolysis products and flocculating agent

- Mass transfer resistances by sludge solids, overlying water, and metaschoepite crusts to impede oxidation by oxygen. Mass-transfer limitations were demonstrated in tests of unmixed simulated sludge with pure oxygen cover gas described in Sections 3.1.1.2 and 3.1.2.3.

(a) Reaction (4.2) presented here, based on observations of genuine sludge and used in previous assessments of sludge expansion (Schmidt and Delegard 2002 and 2003), shows $\mathrm{UO}_{2.25}$ to be a product of anoxic corrosion of uranium metal. However, subsequent work (Sinkov et al. 2008) confirms that $\mathrm{UO}_{2}$ is the end product of anoxic uranium metal corrosion, which occurs stoichiometrically as stated in Reaction (4.1).

$\mathrm{UO}_{2.25}$ was assigned as a uranium metal corrosion product because, by XRD of genuine sludge, it frequently was observed to be the lowest-oxidation-state uranium oxide while $\mathrm{UO}_{2}$ rarely was observed. The $\mathrm{UO}_{2}$ product was rarely observed because it readily forms $\mathrm{UO}_{2.25}$ upon air exposure, including the exposure attendant upon preparing XRD samples for analysis. 
Because of these barriers to oxygenation and the frequent observation of reduced uranium oxides in XRD of genuine sludge, Schmidt and Sexton (2009) and Schmidt and Delegard (2003) assumed that the uranium metal and oxide end state in the STSCs would be an arithmetic sum of two times Reaction $4.2+$ Reaction 4.4 to produce equimolar amounts of $\mathrm{UO}_{2.25}$ and $\mathrm{UO}_{3} \cdot 2 \mathrm{H}_{2} \mathrm{O}$ :

$$
2 \mathrm{U}_{\text {(metal) }}+0.375 \mathrm{O}_{2}+6.5 \mathrm{H}_{2} \mathrm{O} \rightarrow \mathrm{UO}_{2.25}+\mathrm{UO}_{3} \cdot 2 \mathrm{H}_{2} \mathrm{O}+4.5 \mathrm{H}_{2}
$$

Reaction (4.6) reflects accurately the oxygen demand made by termination of anoxic uranium metal corrosion with $\mathrm{UO}_{2}$ and subsequent reaction with oxygen to form equimolar $\mathrm{UO}_{2.25}$ and $\mathrm{UO}_{3} \cdot 2 \mathrm{H}_{2} \mathrm{O}$ :

$$
2 \mathrm{U}_{\text {(metal) }}+0.625 \mathrm{O}_{2}+6 \mathrm{H}_{2} \mathrm{O} \rightarrow \mathrm{UO}_{2.25}+\mathrm{UO}_{3} \cdot 2 \mathrm{H}_{2} \mathrm{O}+4 \mathrm{H}_{2}
$$

Because high-uranium-content $\mathrm{KE}$ canister sludges contain primarily $\mathrm{UO}_{2.25}, \mathrm{UO}_{2}$, and $\mathrm{UO}_{3} \cdot 2 \mathrm{H}_{2} \mathrm{O}$, it was assumed that the $\mathrm{KE}$ canister and $\mathrm{KE}$ floor sludge starting state is an equal uranium mole fraction for each of these three uranium compounds (Table 2.5 of Schmidt and Delegard 2003). The starting state of $\mathrm{KW}$ canister sludge was assumed to be an equimolar mix of $\mathrm{UO}_{2.25}$ and $\mathrm{UO}_{2}$. This composition, more chemically reduced compared with the KE canister and floor sludge mixture, was based on XRD data, density measurements, and consideration of the anoxic storage environment of the spent fuel formerly stored in the KW Basin in closed fuel storage canisters. The starting-state KW settler sludge, defined as a $50 / 50$ volume basis mixture of KE and KW canister sludge (Schmidt 2010), has a postulated initial molebasis uranium compound distribution of about $0.076 \mathrm{U}, 0.410 \mathrm{UO}_{2.25}, 0.410 \mathrm{UO}_{2}$, and $0.105 \mathrm{UO}_{3} \cdot 2 \mathrm{H}_{2} \mathrm{O}$. From these starting-state and end-state uranium compound assignments, and the assumption that the endstate volume fraction of liquid water is 0.75 , the projected volumetric expansion during storage can be calculated.

\subsubsection{Expansion Factors}

The assumptions and the calculation approach for uranium metal, corrosion-based, expansion factors are illustrated in Table 4.1 by safety-basis KW settler sludge. Safety-basis properties for settled density, volume fraction of water, and concentrations of total uranium and uranium metal are provided based on Sludge Technical Databook values (Schmidt 2010). The starting and ending state uranium compounds, on a uranium mole basis as assigned previously (Schmidt and Delegard 2003), are given in the middle of Table 4.1. The molecular weights and particle densities for each uranium compound also are provided. From the input parameters and compound assignments, mass and volume balances are performed on the solids on a $1-\mathrm{cm}^{3}$ unit volume of starting state settled sludge.

For the starting-state sludge, the uranium mass in uranium oxide compounds is calculated by subtracting uranium metal from uranium total. The mass and volume of non-uranium solids representing silica from soil minerals, iron and aluminum hydroxides, Grafoil ${ }^{\circledR}$, and other constituents are calculated by difference, after accounting for the uranium compounds. All non-uranium solids are assumed to remain unchanged during storage with no alteration in mass or volume. The total starting-state and endstate solid mass and particle volume derived from the initial $1-\mathrm{cm}^{3}$ basis of settled sludge then are determined. The additional mass associated with the end-state solids, calculated as the difference between end state and starting state, is supplied by water and oxygen in accordance with the stoichiometry of the corrosion and oxidation reactions. 
The expansion-factor calculation approach assumes that the end-state sludge will have a 0.75 -volume fraction of pore water; conversely, the volume fraction of solids is 0.25 (Schmidt and Delegard 2003). The assumption of 0.75 -volume fraction of pore water is based on evaluating numerous $\mathrm{K}$ Basin sludge characterization data which show that, with considerable variability, most K Basin sludge types have pore volumes near this value. After completing the mass and volume balances, the end-state, settled-sludge volume is calculated by dividing the end-state particle volume $\left(0.43 \mathrm{~cm}^{3}\right.$; Table 4.1$)$ by the end-state volume fraction of solids $(0.25)$ as shown for this example below:

$$
\frac{0.43 \mathrm{~cm}^{3} \text { solids }}{0.25 \mathrm{~cm}^{3} \text { solids } / \mathrm{cm}^{3} \text { settled sludge }}=1.74 \mathrm{~cm}^{3} \text { settled sludge }
$$

Because the starting-state volume is $1.00 \mathrm{~cm}^{3}$ by definition, the expansion factor also is 1.74 .

Table 4.1. Derivation of Corrosion-Based Expansion Factor for KW Settler Sludge

\begin{tabular}{|c|c|c|c|c|}
\hline \multicolumn{5}{|l|}{ Sludge Type Input Parameters } \\
\hline Sludge Type & \multicolumn{4}{|c|}{ KW Settler, Safety Basis } \\
\hline Settled density, $\mathrm{g} / \mathrm{cm}^{3}$ & 3.2 & & & \\
\hline Volume fraction of water & 0.7 & & & \\
\hline $\mathrm{U}$ total, $\mathrm{g} / \mathrm{cm}^{3}$ & 2.1 & & & \\
\hline $\mathrm{U}$ metal, $\mathrm{g} / \mathrm{cm}^{3}$ & 0.16 & & & \\
\hline \multicolumn{5}{|c|}{ Uranium Compounds, Starting-State and End-State Assignments } \\
\hline \multirow[b]{2}{*}{ Uranium and Oxides } & \multirow{2}{*}{$\begin{array}{l}\text { Molecular } \\
\text { weight, g }\end{array}$} & \multirow{2}{*}{$\begin{array}{c}\text { Particle } \\
\text { density, } \\
\mathrm{g} / \mathrm{cm}^{3}\end{array}$} & \multicolumn{2}{|c|}{$\begin{array}{l}\text { U oxide compounds, mole } \\
\text { fraction }\end{array}$} \\
\hline & & & Starting State & End State \\
\hline U metal & 238 & 19.0 & NA & 0.00 \\
\hline $\mathrm{UO}_{2}$ & 270 & 10.95 & 0.417 & 0.00 \\
\hline $\mathrm{U}_{4} \mathrm{O}_{9}$ or $\mathrm{UO}_{2.25}$ & 274 & 11.32 & 0.417 & 0.50 \\
\hline $\mathrm{UO}_{3} \cdot 2 \mathrm{H}_{2} \mathrm{O}$ & 322 & 4.87 & 0.167 & 0.50 \\
\hline \multicolumn{5}{|c|}{ Mass and Volume Balance Based on Solids in $1 \mathrm{~cm}^{3}$ Settled Sludge } \\
\hline \multirow[b]{2}{*}{ Species } & \multicolumn{2}{|c|}{ Starting State } & \multicolumn{2}{|c|}{ End State } \\
\hline & Mass, $\mathrm{g}$ & Volume, $\mathrm{cm}^{3}$ & Mass, g & Volume, $\mathrm{cm}^{3}$ \\
\hline U metal & 0.16 & 0.0084 & 0 & 0 \\
\hline $\mathrm{UO}_{2}$ & 0.92 & 0.084 & 0 & 0 \\
\hline $\mathrm{U}_{4} \mathrm{O}_{9}$ or $\mathrm{UO}_{2.25}$ & 0.93 & 0.082 & 1.21 & 0.11 \\
\hline $\mathrm{UO}_{3} \cdot 2 \mathrm{H}_{2} \mathrm{O}$ & 0.44 & 0.090 & 1.42 & 0.29 \\
\hline Non-U Solids & 0.055 & 0.036 & 0.055 & 0.036 \\
\hline Total Solids & 2.50 & 0.300 & 2.68 & 0.43 \\
\hline \multicolumn{5}{|c|}{ End-State, Settled-Sludge Volume } \\
\hline Volume fraction of water & 0.75 & & & \\
\hline Sludge solids, $\mathrm{cm}^{3}$ & 0.43 & & & \\
\hline Settled-sludge volume, $\mathrm{cm}^{3}$ & 1.74 & $\overline{\text { (Also equal }}$ & s volume expan & sion factor) \\
\hline Calc. settled density, $\mathrm{g} / \mathrm{cm}^{3}$ & 2.30 & & & \\
\hline
\end{tabular}
(based on calculation approach in Schmidt and Delegard [2003]) 
As shown in Table 4.1, oxidation and the increased volume fraction of water in the product material decreases the sludge end-state settled density to $2.3 \mathrm{~g} / \mathrm{cm}^{3}$, a significant drop from the starting-state settled density of $3.2 \mathrm{~g} / \mathrm{cm}^{3}$. Note that a relatively small change in the end-state volume fraction of solids from 0.70 to 0.75 will make a significant difference in the projected sludge expansion. For the safety basis KW Settler sludge, if the end-state volume fraction of water were 0.65 (volume fraction solids $=$ 0.35 ), the estimated end-state expansion factor would be only 1.23 .

\subsection{Volumetric Changes of Sludge Samples During Long-Term Storage}

Laboratory tests with actual and simulated sludge were conducted to understand changes in sludge mass, settled volume, and drying rates under warm irradiated hot cell storage conditions (Delegard et al. 2005). In these tests, six K Basin sludge materials, a control sample of simulated K Basin sludge, and a control sample containing only K Basin supernatant water were stored for 28 months, from May 14, 2002 to September 22, 2004, in capped glass 250-mL graduated cylinders. Excess supernatant water was present in each test over the entire test duration. Settled solids and total volume data were gathered over the storage time test interval. Table 4.2 identifies the samples used, provides total uranium concentration, and shows the initial and final settled-sludge densities. Five of the six actual sludge samples were composites and represented material collected from multiple locations in the KE Basin while one (96-13) was gathered from a single KE canister location. Three of the actual sludge materials contained greater than $50 \%$ uranium on a dry weight basis.

The tests showed that most of the solids compaction occurred in the first week. Subsequent settling to 28 months time provided little additional compaction for most sludge types (Figure 4.2). However, even at one week into the test, the solids settled to greater densities than had been observed in previous characterization tests. The greater settled-sludge densities may have been the result of the greater depth of sludge solids and greater test vessel diameter. The greater 8.2- to $12.5-\mathrm{cm}$ sludge depth in these tests compared with 2 to $5 \mathrm{~cm}$ in most sludge characterization tests could compact the underlying sludge and lead to higher density while the larger $\sim 3.5-\mathrm{cm}$ vessel diameter compared with $\sim 1.5-\mathrm{cm}$ diameter vessels used in most tests would have provided less settling resistance because of wall effects. Only SNF Comp, a composite sludge containing KE floor, KE canister, and residual uranium metal left from previous testing, had a lower settled density than in past measurements. The SNF Comp sludge also had substantially greater settled density at the end of the 28 -month settling than at the beginning.

As shown in Figure 4.2, vortex mixing was performed after 112 days of settling. However, negligible sludge lofting and $0 \%$ to $5 \%$ compaction were evident 4 days after the vortex mixer agitation for all sludge types except SNF Comp. This sludge contained residual reactive uranium metal and generated gas such that a void in the settled SNF Comp solids column disappeared after the vortex agitation. The gas generation in SNF Comp was shown by increasing the volume and gas bubble formation after about 78 days settling in the $\sim 34^{\circ} \mathrm{C}$ hot cell conditions. Visible gas voids within the settled solids subsequently were observed. The delay before the onset of gas generation (induction time) showed again that uranium metal-bearing sludge could lie quiescent for long periods, even at comparatively warm temperatures, before initiating gas generation.

At the completion of the 28-month settling tests in their graduated cylinders in 2004, five of the six genuine sludges were found to be readily re-suspended in their supernatant waters by agitation and 
inversion of the cylinders. However, sludge from the sixth test, sample 96-13, could not be removed by sluicing. Instead, the glass graduated cylinder had to be broken, and the sludge itself was removed as a solid chunk. Post-test interpretation of the 96-13 sludge behavior based on video records and written accounts characterized it as heterogeneous but cohesive and composed of a paste joining larger chunks (Wells et al. 2009). The paste material was estimated to have 3- to 5-kPa shear strength, the chunks have 380 - to $770-\mathrm{kPa}$ shear strength, and the combined material has a shear strength of 15 to $65 \mathrm{kPa}$. The high uranium concentration in this sludge (Table 4.2) is substantiated by the presence of $\mathrm{UO}_{2}, \mathrm{U}_{4} \mathrm{O}_{9}$, and $\mathrm{U}_{3} \mathrm{O}_{7}$ when characterized by XRD in 1996 (Makenas et al. 1997) and the presence of only metaschoepite as determined by XRD in 2007 (Delegard et al. 2007a). The lavender-green color of the 96-13 solids (Figure 3.9 of Delegard et al. 2005) compared with the colors shown in Figure 3.25 indicates that the uranium is $\sim 90 \%$ metaschoepite after the extended settling test. Because of the high metaschoepite fraction and the much greater uranium solution concentrations obtained over $\mathrm{UO}_{3} \cdot 2 \mathrm{H}_{2} \mathrm{O}$ compared with $\mathrm{UO}_{2}$ (Figure 3 of Shoesmith 2000), it is reasonable to suggest that the high strength and self-cementation occurred by recrystallization of metaschoepite over the course of the long-term settling tests.

Table 4.2. Sludge Samples Used in 28-month Settling Test

\begin{tabular}{|c|c|c|c|c|c|c|}
\hline \multirow[b]{3}{*}{ Sludge } & \multirow[b]{3}{*}{ KE Sludge Origin } & \multirow{3}{*}{$\begin{array}{c}\mathrm{U}, \mathrm{wt} \% \\
\text { (dry) }\end{array}$} & \multicolumn{3}{|c|}{ Settled Density, g/ml } & \multirow{3}{*}{$\begin{array}{c}\% \text { Density } \\
\text { Difference }^{(a)}\end{array}$} \\
\hline & & & \multirow{2}{*}{$\begin{array}{c}\text { Prior } \\
\text { Studies }\end{array}$} & \multicolumn{2}{|c|}{ This Study } & \\
\hline & & & & 1 week & Final & \\
\hline KB Sim & Simulated sludge & 0.0 & 2.24 & 2.39 & 2.38 & -0.4 \\
\hline FE-5 & Weasel pit composite & 5.32 & 1.47 & 1.57 & 1.62 & +3.2 \\
\hline $\mathrm{KC}-2 / 3$ & Canister sludge composite & 59.0 & 1.30 & 1.75 & 1.77 & +1.1 \\
\hline $\mathrm{KC}-4$ & $\begin{array}{l}\text { Composite of floor sludge } \\
\text { between canisters }\end{array}$ & 16.6 & 1.26 & 1.28 & 1.28 & 0.0 \\
\hline KC-5 & $\begin{array}{l}\text { Composite of floor sludge } \\
\text { from main basin }\end{array}$ & 6.36 & 1.28 & 1.29 & 1.31 & +1.6 \\
\hline $96-13$ & $\begin{array}{l}\text { Canister sludge that had dried } \\
\text { in prior storage }\end{array}$ & 82.0 & 2.67 & 2.86 & 2.95 & +3.1 \\
\hline SNF Comp & $\begin{array}{l}\text { Floor, canister, and crushed } \\
\text { fuel mix composite }\end{array}$ & 60.2 & 2.32 & 2.02 & 2.20 & +8.9 \\
\hline \multicolumn{7}{|c|}{$\begin{array}{l}\text { \% Density Difference in the final settled-sludge density in the present tests compared with the starting (1 week) } \\
\text { densities: }\end{array}$} \\
\hline \multicolumn{7}{|c|}{$\%$ Density Difference $=\frac{\text { Final density }(\text { this study })-\text { One }- \text { week density }(\text { this study })}{\text { One }- \text { week density }(\text { this study })} \times 100 \%$} \\
\hline
\end{tabular}




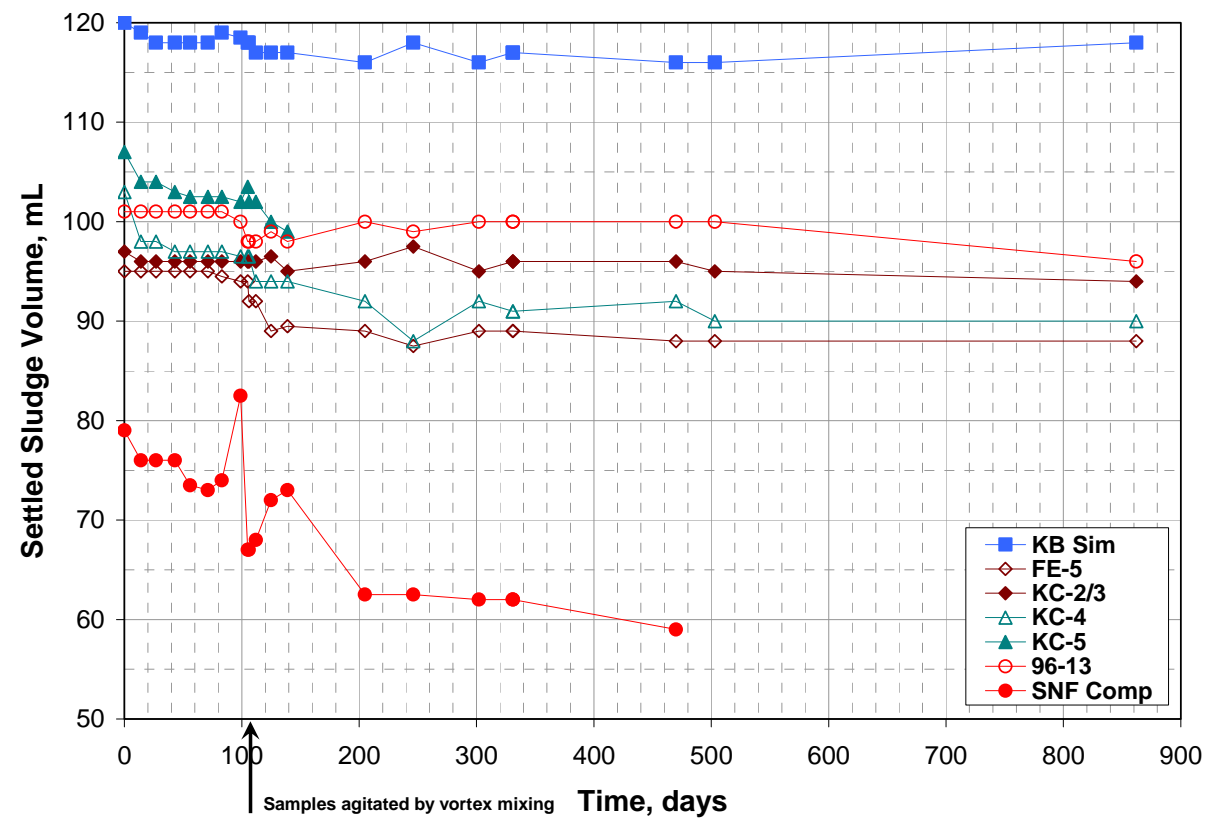

Figure 4.2. Settled-Sludge Volume as a Function of Settling Time

\subsection{Recommended Changes to the Expansion Factor Calculation Approach}

Key findings from the uraninite oxidation investigations, along with findings from other relatively recent studies, provide a technical justification to re-examine the long-term, sludge-expansion phenomenon and the approach used to calculate the sludge-expansion factors used by the STP. Results from the uraninite oxidation testing and other recent investigations provide a more accurate understanding of how uranium oxide settled volumes change during oxidation reactions in static and oxic environments.

Key findings arising from the testing described in this report that impact the sludge-expansion-factor calculation approach include the following:

- Under non-agitated conditions, uraninite oxidation to metaschoepite by dissolved oxygen produces no increase in the bulk settled volume. Although the oxidation of uraninite $\left(\rho \sim 11 \mathrm{~g} / \mathrm{cm}^{3}\right)$ to form metaschoepite $\left(\rho \sim 5 \mathrm{~g} / \mathrm{cm}^{3}\right)$ increases the solids volume by a factor of $\sim 2.6$, the oxidation of uraninite and the formation of metaschoepite occurs from the top of the settled solids column downward. The metaschoepite product crystals forming from the top-down begin to merge through Ostwald ripening with the effect that void spaces in the metaschoepite solids are filled (Figure 3.14). As a result, no change in total settled solids was observed for the $\sim 300$ days of the accelerated experiments conducted at $51{ }^{\circ} \mathrm{C}$ under a pure oxygen atmosphere.

- The oxidation of settled uraninite under static $51{ }^{\circ} \mathrm{C}$ pure oxygenated conditions progresses very slowly and appears to be diffusion-limited as shown by its kinetic behavior. Only the top $5 \mathrm{~mm}$ of the sludge bed was oxidized to metaschoepite after nearly 10 months of exposure (Figure 3.9). This finding supports the technical basis for the projected end-state, uranium-oxide distribution given in Schmidt and Sexton (2009) and Schmidt and Delegard (2003). 
- Under $51^{\circ} \mathrm{C}$ oxygenated conditions, a full $\mathrm{KW}$ containerized sludge simulant containing gibbsite, ferrihydrite, mordenite, OIER, Hanford sand, and $\sim 50 \% / 50 \% \mathrm{UO}_{2} / \mathrm{UO}_{3} \cdot 2 \mathrm{H}_{2} \mathrm{O}$ decreased in settled solids volume by about $25 \%$ over 106 days while a parallel control test run in the absence of oxygen decreased only about $3 \%$. The volume decrease rate coincided with the rate of $\mathrm{UO}_{2}$ oxidation to $\mathrm{UO}_{3} \cdot 2 \mathrm{H}_{2} \mathrm{O}$ and may have been due to better solids packing or coagulation of non-uranium solids with the crystallizing $\mathrm{UO}_{3} \cdot 2 \mathrm{H}_{2} \mathrm{O}$.

- Under strongly stirred, oxygenated, room-temperature conditions, uraninite oxidation produces $\sim 50 \% / 50 \%$ (mole basis) uraninite/metaschoepite settled-solids mixtures of significantly higher solids loading ( 24 volume $\%$ ), a lower settled-solids volume, and higher shear strength than the starting $\mathrm{UO}_{2}$ (uraninite) material and the product $\mathrm{UO}_{3} \cdot 2 \mathrm{H}_{2} \mathrm{O}$ (metaschoepite). The higher solids loading likely is because of better packing of the finer uraninite settled solids in the interstitial pores of the larger metaschoepite crystals. The $\sim 24$ vol\% volumetric solids fraction observed for the 50/50 uraninite/metaschoepite mixtures is typical of those observed for genuine sludges containing other sludge constituents (e.g., ferrihydrite, gibbsite, sand).

Key findings arising from related published observations that impact the sludge-expansion-factor calculation approach are:

- A 28-month-long storage test conducted with six K Basin sludge samples (Delegard et al. 2005) showed that the settled solids volume decreased or remained essentially unchanged with time after an initial 4 days of settling (Figure 4.2). In one test, uranium metal reacted, and hydrogen gas bubbles were generated. After the bubbles were released from the sludge matrix, a net decrease in the settledsludge volume was observed.

- The uncommonly high strength observed for the 96-13 sludge after the 28-month storage test may have been due to Ostwald ripening and crystal growth of the metaschoepite known to be present in this material. This conclusion arises from observations of metaschoepite welding made in the present testing (Figure 3.14) and the high uranium concentrations and presence of metaschoepite in the 96-13 material.

- Under $30 \pm 5^{\circ} \mathrm{C}$ semi-oxic conditions, uraninite in uranium-rich $\mathrm{K}$ Basin sludge samples oxidizes to metaschoepite and other U(VI) phases after 9 years of hot cell storage (Delegard et al. 2007a).

- Results from SCS-CON-220, 240, 250, and 260 containerized sludge sample characterization show that the uranium oxide in the sludge is about 50 to $70 \% \mathrm{U}(\mathrm{IV})$ with the balance being U(VI). ${ }^{\text {(a) }}$ These recent oxidation-state distributions are generally consistent with the uranium-oxide compound distributions postulated for starting-state sludge (Schmidt and Sexton 2009; Schmidt and Delegard 2003).

Overall, these findings indicate that little or no volumetric expansion of settled container sludge or settler tank sludge should occur from uranium oxide oxidation and hydration during sludge storage. As the particle volumes in the sludge increase from uranium-oxidation reactions, void spaces between the

(a) Fiskum SK, JM Billing, SJ Bos, CA Burns, CD Carlson, DS Coffey, JV Crum, RC Daniel, CH Delegard, MK Edwards, OT Farmer, LR Greenwood, SA Jones, D Neiner, BM Oliver, KN Pool, AJ Schmidt, RW Shimskey, CZ Soderquist, CJ Thompson, ML Thomas, T Trang-Le, and MW Urie. 2009. Characterization Data Package for Containerized Sludge Samples Collected from Engineered Containers SCS-CON-240, 250, 260, and 220. PNNL-19035 (Limited Distribution), Pacific Northwest National Laboratory, Richland, Washington. 
sludge particles will be partially filled such that the bulk settled volume of the sludge bed does not increase.

Because of this enhanced understanding of the behavior of high-uranium-content mixtures and actual sludge samples during static oxic storage, a revised approach is proposed to calculate sludge expansion factors. The approach takes note of the following two observations:

- The bulk volume of sludge does not increase as uranium oxides undergo further oxidation.

- As a consequence, the volume fraction of water decreases during containerized storage.

Although sludge volumes generally decrease with aging and exposure to oxygen, there is no question that the corrosion products from uranium metal oxidation are more voluminous than the starting metal. This is observed in every test in which uranium metal is oxidized in water. For example, in Gas Generation III testing, irradiated metallic uranium N Reactor fuel particles were reacted to completion under aqueous anoxic conditions, and the volumes of the predominantly uraninite settled reaction products were measured (Schmidt et al. 2003). The observed volumetric expansion was less than, but generally consistent with, the expansion factor developed for uranium metal pieces in partially oxic storage conditions as documented in the Sludge Technical Databook. Based on the Sludge Technical Databook fuel-piece expansion factor, for each gram of uranium metal corroded anoxically to $\mathrm{UO}_{2}$ and then oxidized by oxygen to equimolar $\mathrm{UO}_{2.25}$ and $\mathrm{UO}_{3} \cdot 2 \mathrm{H}_{2} \mathrm{O}, 0.8 \mathrm{~cm}^{3}$ of end-state sludge will be created. The revised expansion factor calculation approach, illustrated using settler sludge in Table 4.3, retains this conservative volume accounting to address the expansion associated with uranium metal.

The revised calculation approach for expansion factors includes the same starting-state and end-state uranium compound assignments and includes the same mass and volume balance methods as were used in the original calculation approach to determine the end-state sludge solids composition. In the revised approach, however, the starting-state and ending-state settled-sludge volumes are held constant with the exception of volume accounting to address uranium metal anoxic corrosion and subsequent reaction of $\mathrm{UO}_{2}$ with oxygen to form equimolar $\mathrm{UO}_{2.25}$ and $\mathrm{UO}_{3} \cdot 2 \mathrm{H}_{2} \mathrm{O}$. This constant volume assumption is consistent with measurements of sludge sample volume during long-term storage. It is also consistent with volume measurements in current testing in which oxidizing conditions were accelerated by increased temperature and increased oxygen partial pressure. To account for the volumetric expansion resulting from uranium metal anoxic corrosion and subsequent reaction with oxygen to form equimolar $\mathrm{UO}_{2.25}$ and $\mathrm{UO}_{3} \cdot 2 \mathrm{H}_{2} \mathrm{O}$, the mass of uranium metal in the starting-state sludge is multiplied by the projected volume expansion of $0.8 \mathrm{~cm}^{3}$ end state settled sludge per gram of uranium metal for fuel-piece sludge given in the Sludge Technical Databook (Schmidt 2010). Detailed calculations and supporting assumptions on corrosion-based expansion factors derived using the values provided in Rev 14B of the Sludge Technical Databook (Schmidt 2010) and the revised approach are given in Appendix B.

With the revised calculation approach in which only uranium metal corrosion results in settled solids volume expansion, an expansion factor of 1.13 is calculated for KW safety basis settler sludge (Table 4.3). With this approach, the calculated end-state, volume fraction of water, 0.69 , and settledsludge density, $2.99 \mathrm{~g} / \mathrm{cm}^{3}$, are credible. Expansion factor calculations for safety basis KW Container Sludge (SCS-CON-210 and 220) and safety basis KE Container Sludge (SCS-CON-240, 250 and 260), using the revised approach are summarized in Table 4.4 and Table 4.5 , respectively. The respective projected corrosion-based expansion factors of 1.07 and 1.02 for these sludge types are very small. 


\subsection{Additional Considerations for Future Updates to Databook Expansion-Factor Calculations}

The revised calculation approach for expansion factors illustrated in Table 4.3 through Table 4.5 are based on input values from Revision 14B of the Sludge Technical Databook (Schmidt 2010). As new data are collected and evaluated from the Engineered Container sludge sampling campaigns, it is expected that updated uranium metal concentration values will be established in a future revision to the Sludge Technical Databook. Furthermore, the ongoing sludge sampling campaign includes determination of the distribution of the uranium oxide oxidation states, as $\mathrm{U}(\mathrm{IV})$ and $\mathrm{U}(\mathrm{VI})$, in the sludge. Therefore, updates of sludge expansion factors should be based on the most up-to date project-approved uranium metal and uranium-oxide oxidation-state distribution values for starting-state sludge.

For sludge streams exhibiting low expansion factors such as KE Floor and Canister sludge, Schmidt and Delegard (2003) included an expansion factor multiplier of 50\% to account for uncertainties in predicting the void fraction and the starting-state and ending-state uranium compounds. This multiplier is included within the Sludge Technical Databook expansion factors for some sludge streams (Schmidt 2010). Future revisions to expansion factors may consider using an expansion factor multiplier for the KE and KW Container sludge streams. 
Table 4.3. Derivation of Corrosion-Based Expansion Factor for KW Settler Sludge Based on the 2010 Revised Calculation Approach

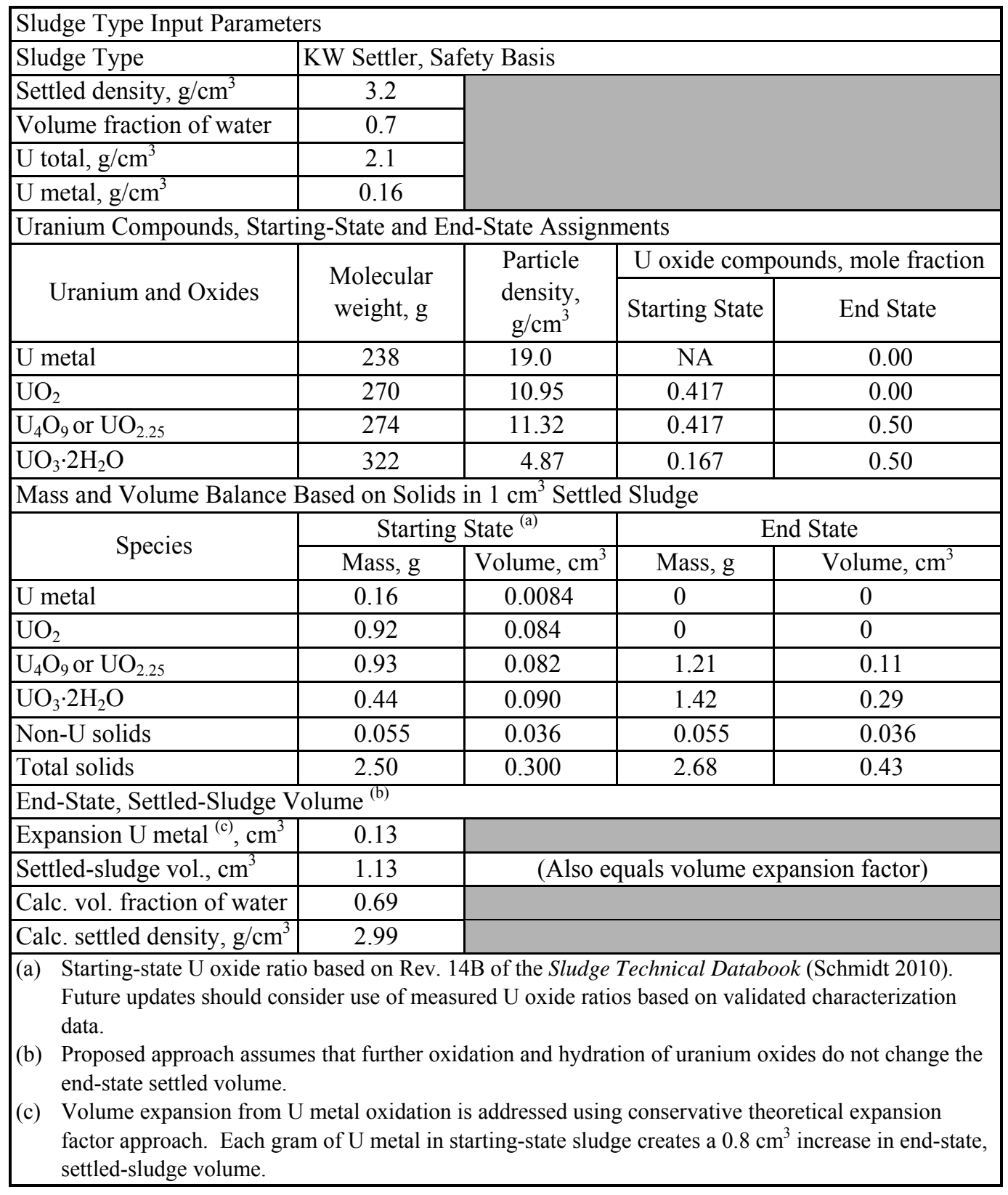


Table 4.4. Derivation of Corrosion-Based Expansion Factor for KW Containerized Sludge Based on the 2010 Revised Calculation Approach

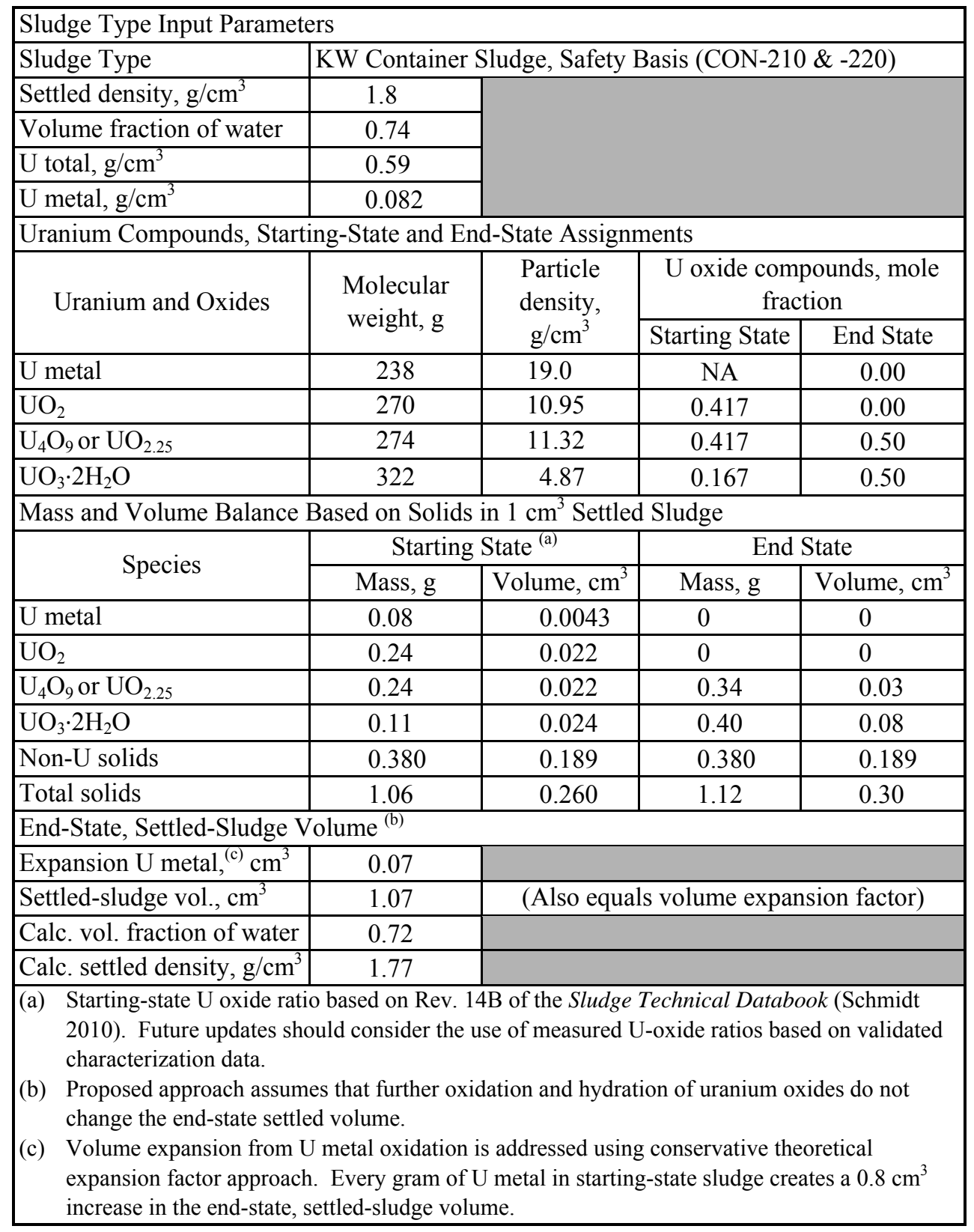




\subsection{Summary and Conclusions}

The chemical and physical properties of $\mathrm{K}$ Basin sludge are expected to change with time because of chemical reactions whose rates are increased with increasing temperature. Changes in settled-solids volume and in solids strength with time can impact the planned storage container filling level and the aggressiveness of retrieval methods in the KW Basin pool and in T Plant. The volumes occupied by the settled-sludge solids potentially can increase due to chemical reactions, the most important of which are uranium metal corrosion to form uranium dioxide and the subsequent oxidation of uranium dioxide by oxygen to form metaschoepite. These reactions and other reactions in the sludge can affect the sludge strength by intergrowth of sludge phase crystals and by compaction of the sludge solids manifested as an increased solids fraction in the settled sludge.

Results of tests conducted to determine the effects of $50^{\circ} \mathrm{C}$ oxygenated water exposure on settled quiescent uraninite $\left(\mathrm{UO}_{2}\right)$ slurry and a full simulant of $\mathrm{KW}$ containerized sludge are reported in the present study. Results of additional tests of heating of the same wetted sludge solids materials to $95^{\circ} \mathrm{C}$ without additional oxygen also are provided. The tests were conducted to determine the effects of oxygen and heat on sludge composition and physical properties. Shear-strength measurements by vane rheometry also were conducted for $\mathrm{UO}_{2}$ slurry, mixtures of $\mathrm{UO}_{2}$ and metaschoepite $\left(\mathrm{UO}_{3} \cdot 2 \mathrm{H}_{2} \mathrm{O}\right)$, and simulated KW containerized sludge prepared under room-temperature conditions. The results from these tests and related previous tests are compared to determine whether the settled solids in the K Basin sludge materials change in volume because of oxidation by dissolved atmospheric oxygen to form metaschoepite, by heating, and by other mechanisms and to determine the effects of sludge composition on shear strength.

Stoichiometric calculations based on compound particle density show that uranium solids particle volumes necessarily increase by the uranium metal $\rightarrow$ uranium dioxide $\rightarrow$ metaschoepite oxidation sequence observed in K Basin sludge. All other major sludge compounds (e.g., gibbsite, ferrihydrite, sand, ion exchange media) are chemically stable and of low solubility and, therefore, are not expected to alter during extended storage. If the inter-particle porosity of settled sludge, reflected as the volume fraction of water, does not change during these uranium oxidation processes, the volume of settled sludge must increase. Previous conservative estimates of sludge expansion presented in the Sludge Technical Databook (Schmidt 2010) are based on the assumption that the volume fraction of water remains constant at about 0.75 or increases as sludge constituents oxidize with the effect that settled $\mathrm{K}$ Basin sludge is predicted to increase in volume. This increase, in turn, decreases the projected allowable sludge container fill levels, increases the number of containers required for storage, and increases overall costs of both the Phase 1 and Phase 2 sludge management activities.

However, if the interstitial volume fraction decreases because of sludge solid reactions, compaction, or intergrowth and recrystallization of metaschoepite, the settled-sludge strength would be expected to increase just as the increase of the solids fraction in kaolin-water mixtures increases the shear strength. If sludge strengthens, recovery by simple agitation or by water jet erosion may be challenged and thus necessitate the use of more complex and aggressive retrieval methods.

Observations from experiments performed under this testing and observations gathered from associated previous testing of genuine sludge materials show that, for the systems studied, the settledsolids volume remains the same or decreases as uranium dioxide $\left(\mathrm{UO}_{2}\right)$ oxidizes to metaschoepite $\left(\mathrm{UO}_{3} \cdot 2 \mathrm{H}_{2} \mathrm{O}\right)$ in uranium-only simulated sludge mixtures, in full-sludge simulants, and in genuine sludge. 
Specific results from the analyses in this report and prior findings and their importance to $K$ Basin storage and processing are summarized by the following points:

- Under non-agitated conditions, uraninite oxidation to metaschoepite by dissolved oxygen produces no increase in settled volume. Metaschoepite product crystals form from the top-down and begin to form a crust layer through Ostwald ripening. No change in total settled solids volume was observed for the $\sim 300$ days of the accelerated uraninite oxidation experiments conducted at $51^{\circ} \mathrm{C}$ under a pure oxygen atmosphere.

- The oxidation of settled uraninite under static $51{ }^{\circ} \mathrm{C}$ pure oxygenated conditions progresses very slowly and appears to be diffusion-limited as shown by its kinetic behavior. Only the top $5 \mathrm{~mm}$ of the sludge bed was oxidized to metaschoepite after nearly 10 months of exposure. Under $20^{\circ} \mathrm{C}$ atmospheric air conditions $\left(\mathrm{P}_{\mathrm{O} 2}=0.21 \mathrm{~atm}\right)$, the metaschoepite solids layer depth is projected to be $\sim 5 \mathrm{~mm}$ after 30 years. The product metaschoepite solids at this thickness are weak and friable.

- A 28-month-long storage test (Delegard et al. 2005) conducted with six K Basin sludge samples showed that the settled-solids volume decreased or remained essentially unchanged with storage time after an initial 4 days of settling. After the 28-month settling, five of the sludge samples were readily re-suspended to pourable slurries by agitation. However, the sixth sludge, a uranium-rich, fuel canister sludge, 96-13, containing metaschoepite as the only XRD-identifiable phase, showed considerable strength and could be retrieved from its glass test vessel only by breaking the vessel.

These findings mean that for solids very rich in $\mathrm{UO}_{2}$, long-term storage under stagnant aerated conditions will form a thin metaschoepite crust that is readily broken. The underlying $\mathrm{UO}_{2}$ material may compact somewhat with time, but, because little appreciable change in settled solids strength was seen after nearly a year settling at $51^{\circ} \mathrm{C}$ in laboratory tests, little increase in strength is anticipated during lower temperature but longer term storage.

The observations from the 28-month settling test with uranium- and metaschoepite-rich genuine sludge and the studies with the uraninite oxidation suggests that metaschoepite crystal ripening and intergrowth may lead to high sludge strengths. In this case, the presence of relatively high amounts of metaschoepite within the settled solids layer was necessary to produce the strong product material.

$K$ Basin sludges rich in metaschoepite can be expected to self-cement by Ostwald ripening to produce uncommonly strong agglomerates ( $\sim 0 \mathrm{kPa}$ to $100 \mathrm{kPa}$ ) similar to the behavior shown by the 96-13 sludge in the 28-month settling tests. Because of the low solubility of $\mathrm{UO}_{2}$, similar gains in strength by Ostwald ripening for $\mathrm{UO}_{2}$-rich sludge cannot occur.

- Under $51^{\circ} \mathrm{C}$ oxygenated conditions, a full $\mathrm{KW}$ containerized sludge simulant containing gibbsite, ferrihydrite, mordenite, OIER, Hanford sand, and $\sim 50 \% / 50 \% \mathrm{UO}_{2} / \mathrm{UO}_{3} \cdot 2 \mathrm{H}_{2} \mathrm{O}$ decreased in settled solids volume by about $25 \%$ over 106 days while a parallel control test run in the absence of oxygen decreased only about $3 \%$. The volume decrease coincided with oxidation of $\mathrm{UO}_{2}$ to $\mathrm{UO}_{3} \cdot 2 \mathrm{H}_{2} \mathrm{O}$ and may have been due to better solids packing or coagulation of non-uranium solids with the crystallizing $\mathrm{UO}_{3} \cdot 2 \mathrm{H}_{2} \mathrm{O}$.

- Under warm $\left(30 \pm 5^{\circ} \mathrm{C}\right)$ semi-oxic conditions, the uraninite in uranium-rich $\mathrm{K}$ Basin sludge samples oxidizes to metaschoepite and other U(VI) phases after 9 years of hot cell storage (Delegard et al. 2007a). 
These findings mean that, unlike uraninite-rich sludges that form continuous layers or networks of product metaschoepite upon reaction with oxygen or which already have high metaschoepite concentrations, sludges more dilute in uraninite or metaschoepite may be unable to produce continuous metaschoepite layers that inhibit further oxidation or which self-cement to form highstrength agglomerates. The metaschoepite may, instead, act to coagulate non-uranium sludge solids and produce settled solids that are more tightly packed and have a decreasing settled-solids volume and a lower volume fraction of void water. Although marked strength increases were not noticeable for the materials tested after 100 days of reaction, the decreased water void volume ultimately may act to increase the settled-sludge strength. However, the long-range binding of sludge solids through metaschoepite recrystallization with itself will not be possible because of insufficient metaschoepite.

- Under strongly stirred oxygenated room temperature conditions, uraninite oxidation produces $\sim 50 \% / 50 \%$ uraninite/metaschoepite settled-solids mixtures (mole basis; $\sim 81 \mathrm{wt} \%$ uranium, dry basis) that have significantly higher solids loading ( $\sim 24$ volume $\%)$ and shear strength than the starting uraninite material and the product metaschoepite. A shear strength in excess of 26,000 $\mathrm{Pa}$ was noted for one such mixture, and shear strengths of $2000 \mathrm{~Pa}$ were routinely observed. In contrast, pure uraninite and metaschoepite settled slurries had shear strengths measured in the tens to hundreds of $\mathrm{Pa}$. The higher solids loading likely is because of better packing of the finer uraninite settled solids within the interstitial pores of the larger metaschoepite crystals.

- The shear strengths of simulated KW containerized sludge, which contains a variety of sludge components and about $28 \mathrm{wt} \%$ uranium, dry basis, ranged from 500 to $700 \mathrm{~Pa}$ after $\sim 2 \frac{1}{2}$ months settling.

- Previous K Basin sludge shear-strength measurements establish the 1 to 8,200 Pa range provided in the Sludge Technical Databook (Schmidt 2010). The shear strength is affected by sample history and generally increases with increasing undisturbed settling time. Within settling times ranging from several days to several weeks, shear strengths ranged from less than $100 \mathrm{~Pa}$ to about 3,000 $\mathrm{Pa}$ and had $240,4,000,1,000,400$, and 8,200 Pa shear strengths after 20 to 30 days settling while containing, respectively, 1.7, 5, 6, 17, and 60 dry basis wt\% uranium (Poloski et al. 2002).

- Shear strengths measured in 2009 for samples from the KW containers SCS-CON-240, 250, and 260, passed through $500-\mu \mathrm{m}$ sieves and settled for several days to several weeks were about 300,300 , and $80 \mathrm{~Pa}$, respectively. The total uranium concentrations for the same respective materials were 4.91, 5.25 , and $6.61 \mathrm{wt} \%$ (dry basis). The shear-strengths for the settled $<500-\mu \mathrm{m}$ fraction from SCSCON-220 were $\sim 90 \mathrm{~Pa}$ and $\sim 500 \mathrm{~Pa}$, but the measurements were of low reliability. The dry-basis uranium concentration was $34.6 \mathrm{wt} \%$. $^{(a)}$

The better packing of the 50\%/50\% uraninite/metaschoepite mixtures to 24 vol\% volumetric solids fraction is typical of those observed for genuine sludges containing the several other key sludge constituents (e.g., ferrihydrite, gibbsite, sand). Simulated KW containerized sludge samples are relatively weak compared with the 50\%/50\% uraninite/metaschoepite mixtures. However, measurements of actual sludge show no clear trend relating shear strength to uranium concentration

(a) Fiskum SK, JM Billing, SJ Bos, CA Burns, CD Carlson, DS Coffey, JV Crum, RC Daniel, CH Delegard, MK Edwards, OT Farmer, LR Greenwood, SA Jones, D Neiner, BM Oliver, KN Pool, AJ Schmidt, RW Shimskey, CZ Soderquist, CJ Thompson, ML Thomas, T Trang-Le, and MW Urie. 2009. Characterization Data Package for Containerized Sludge Samples Collected from Engineered Containers SCS-CON-240, 250, 260, and 220. PNNL-19035 (Limited Distribution), Pacific Northwest National Laboratory, Richland, Washington. 
but do indicate increasing shear strength with increased settling time. Shear strengths of genuine sludge can alter because of continued uraninite oxidation and mixing by remobilization and transfer.

- Results from SCS-CON-220, -240, 250, and 260 containerized sludge sample characterization show that the uranium oxide in the sludge is about 50 to $70 \% \mathrm{U}(\mathrm{IV})$, such as uraninite, with the balance being $\mathrm{U}(\mathrm{VI})$, such as metaschoepite or other more mineralized $\mathrm{U}(\mathrm{VI})$ phases. ${ }^{\text {(a) }}$

These recent oxidation state distributions are generally consistent with the uranium oxide compound distributions postulated for starting-state sludge (Schmidt and Sexton 2009; Schmidt and Delegard 2003).

The overall observation that the settled-sludge solids volume remains the same or decreases with time and oxidation means that projections of the increase of the volume of stored sludge solids made in the Sludge Technical Databook (Schmidt 2010) are over-estimated except for the expansion factor attendant upon the anoxic aqueous corrosion of uranium metal to produce $\mathrm{UO}_{2}$ and subsequent reaction with oxygen to form equimolar $\mathrm{UO}_{2.25}$ and $\mathrm{UO}_{3} \cdot 2 \mathrm{H}_{2} \mathrm{O}$. Accordingly, it is suggested that the approach to determining expansion factors to project sludge volumes upon storage be revised.

The suggested revised calculation approach for expansion factors would include the same startingand end-state uranium compound assignments and include the same mass and volume balance to project the end-state, sludge-solids composition. Based on measurements of sludge sample volume during longterm storage and volume measurement in testing under oxidizing conditions accelerated by increased temperature and increased oxygen partial pressure, the starting-state and end-state settled-sludge volumes are held constant with the exception of volume increase to form equimolar quantities of $\mathrm{UO}_{2.25}$ and $\mathrm{UO}_{3} \cdot 2 \mathrm{H}_{2} \mathrm{O}$ from uranium metal anoxic corrosion and subsequent reaction with dissolved oxygen. To account for the volumetric expansion resulting from uranium metal corrosion and oxidation, the mass of uranium metal in the starting-state sludge is multiplied by the projected volume expansion of $0.8 \mathrm{~cm}^{3}$ endstate settled sludge per gram of uranium metal for fuel-piece sludge given in the Sludge Technical Databook (Schmidt 2010).

(a) Fiskum SK, JM Billing, SJ Bos, CA Burns, CD Carlson, DS Coffey, JV Crum, RC Daniel, CH Delegard, MK Edwards, OT Farmer, LR Greenwood, SA Jones, D Neiner, BM Oliver, KN Pool, AJ Schmidt, RW Shimskey, CZ Soderquist, CJ Thompson, ML Thomas, T Trang-Le, and MW Urie. 2009. Characterization Data Package for Containerized Sludge Samples Collected from Engineered Containers SCS-CON-240, 250, 260, and 220. PNNL-19035 (Limited Distribution), Pacific Northwest National Laboratory, Richland, Washington. 


\subsection{References}

Buck EC, BK McNamara, and BD Hanson. 2004. Alternative Conceptual Model for Colloid Generation from Commercial Spent Nuclear Fuel. PNNL-14306, Pacific Northwest National Laboratory, Richland, Washington. Available at:

http://www.pnl.gov/main/publications/external/technical_reports/PNNL-14306.pdf. Accessed $11 / 10 / 2010$.

Burbank D. 2009. Sludge Simulant Strategy and Design Basis. PRC-STP-00034, Rev. 0, CH2M HILL Plateau Remediation Company, Richland, Washington.

Burns CA, PA Gauglitz, and RL Russell. 2010. Shear Strength Correlations for Kaolin/Water Slurries:

A Comparison of Recent Measurements with Historical Data. PNNL-19094, Pacific Northwest National Laboratory, Richland, Washington. Available at:

http://www.pnl.gov/main/publications/external/technical reports/PNNL-19094.pdf. Accessed

$11 / 10 / 2010$.

Delegard CH, AP Poloski, AJ Schmidt, and JW Chenault. 2005. Characterization of Compaction and Dryout Properties of KE Basin Sludge during Long-Term Storage. PNNL-15092, Pacific Northwest National Laboratory, Richland, Washington. Available at:

http://www.pnl.gov/main/publications/external/technical_reports/PNNL-15092.pdf. Accessed $11 / 10 / 2010$.

Delegard CH, AJ Schmidt, and JW Chenault. 2007a. Characteristics of KE Basin Sludge Samples Archived in the RPL - 2007. PNNL-17078, Pacific Northwest National Laboratory, Richland, Washington.

Delegard CH, AJ Schmidt, and BM Thornton. 2007b. Hydrothermal Testing of K Basin Sludge and N Reactor Fuel at Sludge Treatment Project Operating Conditions. PNNL-16496, Pacific Northwest National Laboratory, Richland, Washington. Available at:

http://www.pnl.gov/main/publications/external/technical_reports/PNNL-16496.pdf. Accessed $11 / 10 / 2010$.

Ferrell RT and DM Himmelblau. 1967. "Diffusion Coefficients of Nitrogen and Oxygen in Water." Journal of Chemical and Engineering Data 12(1):111-115.

Finch R and T Murakami. 1999. "Systematics and Paragenesis of Uranium Minerals." In: Uranium: Mineralogy, Geochemistry and the Environment, p. 115. PC Burns and R Finch, editors. Mineralogical Society of America, Washington, DC.

Gauglitz PA, B Buchmiller, JJ Jenks, J Chun, RL Russell, AJ Schmidt, and MM Mastor. 2010. The Disruption of Vessel-Spanning Bubbles with Sloped Fins in Flat-Bottom and 2:1 Elliptical-Bottom Vessels. PNNL-19345, Rev 0, Pacific Northwest National Laboratory, Richland, Washington. Available at: http://www.pnl.gov/main/publications/external/technical_reports/PNNL-19345.pdf. Accessed $11 / 11 / 2010$. 
Grandstaff DE. 1976. "A Kinetic Study of the Dissolution of Uraninite." Economic Geology 71(8):1493-1506.

Grenthe I, J Drożdżyński, T Fujino, EC Buck, TE Albrecht-Schmitt, and SF Wolf. 2008. "Uranium." Chapter Five of The Chemistry of the Actinide and the Transactinide Elements, $3{ }^{\text {rd }}$ edition, LR Morss, NM Edelstein, and J Fuger, editors, Springer, Dordrecht, The Netherlands.

Hill SR. 2010. Consolidation of K Basin Sludge Data and Experiences on Agglomerate Formation. PRC-STP-00274, Rev. 0, CH2M HILL Plateau Remediation Company, Richland, Washington.

Honeyman JO and RJ Rourk. 2009. Sludge Treatment Project - Project Execution Plan. KBC-30811, Rev 3 (PRC-EDC-09-43288, Rev. 3), CH2M HILL Plateau Remediation Company, Richland, Washington.

Johnson ME. 2010. Preliminary STP Container and Settler Sludge Process System Description and Material Balance. HNF-41051, Rev 6, CH2M HILL Plateau Remediation Company, Richland, Washington.

Krug HJ and H. Brandtstädter. 1999. "Morphological Characteristics of Liesegang Rings and Their Simulations.” Journal of Physical Chemistry A 103(39):7811-7820.

Makenas BJ, TL Welsh, RB Baker, EW Hoppe, AJ Schmidt, J Abrefah, JM Tingey, PR Bredt, and GR Golcar. 1997. Analysis of Sludge from Hanford K East Basin Canisters. HNF-SP-1201, Duke Engineering and Services Hanford, Inc., Richland, Washington. Available at:

http://www.osti.gov/bridge/servlets/purl/353240-lcEee5/webviewable/353240.pdf. Accessed 11/11/2010.

McGraw-Hill. 2003. Dictionary of Geology and Mineralogy, $2^{\text {nd }}$ Edition. McGraw-Hill, New York, New York.

Perry, RH, D Green, and JO Maloney. 1984. Perry's Chemical Engineers' Handbook, $6^{\text {th }}$ Edition. McGraw-Hill, New York, New York.

Poloski AP, PR Bredt, A Schmidt, RG Swoboda, JW Chenault, and SR Gano. 2002. Thermal Conductivity and Shear Strength of K Basin Sludge. PNNL-13911, Pacific Northwest National Laboratory, Richland, Washington. Available at: http://www.pnl.gov/main/publications/external/technical_reports/PNNL-13911.pdf. Accessed $11 / 11 / 2010$.

Purolite. 2007. "Product Data Sheets for NRW37, NRW100, and NRW400." The Purolite Company, Bala Cynwyd, Pennsylvania. Available at:

http://www.purolite.com/RelId/606306/ProductID/161/isvars/default/productzoom.htm

(NRW37, mixed bed) (accessed 11/11/2010);

http://www.purolite.com/RelId/606306/ProductID/49/isvars/default/productzoom.htm (NRW100, cation) (accessed 11/11/2010); http://www.purolite.com/RelId/606306/ProductID/44/isvars/default/productzoom.htm (NRW400, anion) (accessed 11/11/2010). 
Ramachandran CE, BA Williams, JA van Bokhoven, and JT Miller. 2005. "Observation of a Compensation Relation for $n$-hexane Adsorption in Zeolites with Different Structures: Implications for Catalytic Activity." Journal of Catalysis 233:100-108.

Russell RL, DE Rinehart, PA Gauglitz, J Chun, and AJ Schmidt. 2010. Results of Kaolin Clay Slump Testing. PNNL-19713, Pacific Northwest National Laboratory, Richland, Washington.

Schmidt AJ. 2010. Spent Nuclear Fuel Project Databook, Volume 2, Sludge. HNF-SD-SNF-TI-015, Rev. 14A, CH2M HILL Plateau Remediation Company, Richland, Washington.

Schmidt, AJ and CH Delegard. 2002. Assessment of K Basin Sludge Volume Expansion Resulting from Uranium Corrosion during Storage. PNNL-13786, Pacific Northwest National Laboratory, Richland, WA. Available at: http://www.pnl.gov/main/publications/external/technical_reports/PNNL-13786.pdf. Accessed 11/11/2010.

Schmidt AJ and CH Delegard. 2003. Updated Volumetric Expansion Factors for K Basin Sludge During Storage. PNNL-14228, Pacific Northwest National Laboratory, Richland, Washington. Available at: http://www.pnl.gov/main/publications/external/technical reports/PNNL-14228.pdf. Accessed $11 / 11 / 2010$.

Schmidt AJ and RA Sexton. 2009. Supporting Basis for SNF Project Sludge Technical Data Book. SNF-7765, Rev. 3d, Fluor Hanford, Inc., Richland, Washington.

Schmidt AJ, KL Silvers, PR Bredt, CH Delegard, EW Hoppe, JM Tingey, AH Zacher, TL Welsh, and RB Baker. 1999. Supplementary Information on K-Basin Sludges. HNF-2367, Rev. 0, Fluor Daniel Hanford, Richland, Washington. Available at: http://www.osti.gov/energycitations/servlets/purl/781588-OGDK2O/webviewable/781588.pdf. Accessed $11 / 11 / 2010$.

Schmidt AJ CH Delegard, SA Bryan, MR Elmore, RL Sell, KL Silvers, SR Gano, and BM Thornton. 2003. Gas Generation from K East Basin Sludges and Irradiated Metallic Uranium Fuel Particles Series III Testing. PNNL-14346, Pacific Northwest National Laboratory, Richland, Washington. Available at: http://www.pnl.gov/main/publications/external/technical_reports/PNNL-14346.pdf. Accessed 11/11/2010.

Serne RJ, BN Bjornstad, HT Schaef, BA Williams, DC Lanigan, DG Horton, RE Clayton, AV Mitroshkov, VL Legore, MJ O'Hara, CF Brown, KE Parker, IV Kutnyakov, JN Serne, GV Last, SC Smith, CW Lindenmeier, JM Zachara, and D Burke. 2002. Characterization of Vadose Zone Sediment: Uncontaminated RCRA Borehole Core Samples and Composite Samples. PNNL-13757-1, Pacific Northwest National Laboratory, Richland, Washington. Available at: http://www.pnl.gov/main/publications/external/technical reports/pnnl-13757-1.pdf. Accessed $11 / 11 / 2010$. 
Shoesmith DW. 2000. "Fuel Corrosion Processes under Waste Disposal Conditions." Journal of Nuclear Materials 282:1-31.

Shoesmith DW and S Sunder. 1991. An Electrochemistry-Based Model for the Dissolution of $\mathrm{UO}_{2}$. AECL-10488, Whiteshell Laboratories, Pinawa, Manitoba, Canada.

Sinkov SI, CH Delegard, and AJ Schmidt. 2008. Preparation and Characterization of Uranium Oxides in Support of the K Basin Sludge Treatment Project. PNNL-17678, Pacific Northwest National Laboratory, Richland, Washington. Available at:

http://www.pnl.gov/main/publications/external/technical_reports/PNNL-17678.pdf. Accessed $11 / 11 / 2010$.

Sinkov, SI, CH Delegard, and AJ Schmidt. 2010. Mitigation of Hydrogen Gas Generation from the Reaction of Water with Uranium Metal in K Basins Sludge. PNNL-19135. Pacific Northwest National Laboratory, Richland, Washington. Available at:

http://www.pnl.gov/main/publications/external/technical reports/PNNL-19135.pdf. Accessed $11 / 11 / 2010$.

Wells BE, CW Enderlin, PA Gauglitz, and RA Peterson. 2009. Assessment of Jet Erosion for Potential Post-Retrieval K-Basin Settled Sludge. PNNL-18831, Pacific Northwest National Laboratory, Richland, Washington. Available at: http://www.pnl.gov/main/publications/external/technical_reports/PNNL18831.pdf. Accessed 11/11/2010.

Zachara JM, SC Smith, C Liu, JP McKinley, RJ Serne, and PL Gassman. 2002. "Sorption of $\mathrm{Cs}^{+}$to Micaceous Subsurface Sediments from the Hanford Site, USA." Geochimica et Cosmochimica Acta 66(2):193-211.

Zheng J, WB Carlson, and JS Reed. 1995. "The Packing Density of Binary Powder Mixtures.” Journal of the European Ceramic Society 15:479-483. 


\section{Appendix A}

\section{XRD Diffraction Scans}

X-ray powder diffraction analyses were performed on a Scintag PAD V X-ray Diffractometer $(\mathrm{Cu} K \alpha$ radiation, $\lambda=1.5418 \AA$ ). Data were collected in a step-scan mode between 10 and $65^{\circ} 2$-theta with a step size of $0.02^{\circ}$ and a counting time of 2.4 seconds. The X-ray tube operating conditions were $45 \mathrm{kV}$ and $40 \mathrm{~mA}$. The daily calibrations were done after the samples were scanned; however, the instrument was found to be in calibration. The daily calibration using the NIST SRM 640, Si (111) peak at $28.44^{\circ} 2$-theta was analyzed for peak position.

X-ray diffraction scans were taken of the samples U-3 (unheated uranium oxide mixture), U-1 (heated uranium oxide mixture), S-start (unheated KW Container sludge simulant), and S-6 (heated KW Container sludge simulant). An overlay of the XRD powder patterns obtained for all four samples is presented in Figure A.1. From this figure, one can see that the U-1 and U-3 samples are similar in composition and that S-6 and S-start samples are similar in composition. The XRD scans for each of these samples with the corresponding PDF cards for the identified crystalline phases are shown in Figures A.2 through A.5.

The crystalline phases identified in these samples are listed in Table A.1. Note that no evidence of dehydrated schoepite (with a primary diffraction peak at $\sim 17.3^{\circ}, 2$-theta) was found in any sample and metaschoepite (the hydrated precursor to dehydrated schoepite) was present in both the unheated and heated materials. This means that the metaschoepite survived the heating step for both U-1 and S-6 samples. No evidence of boehmite or other product from dehydration of gibbsite was observed in either the S-start or S-6 samples while gibbsite itself remained in the heated materials. Both goethite and hematite were found in the S-start and S-6 samples. Therefore, goethite was not destroyed by dehydration to form hematite. 
Table A.1. Phases Found in Unheated and Heated Samples by XRD

\begin{tabular}{|c|c|c|c|c|c|}
\hline Sample & $\begin{array}{c}\text { XRD Scan } \\
\text { Date }\end{array}$ & $\begin{array}{l}\text { Identified } \\
\text { Crystalline } \\
\text { Phases }\end{array}$ & Formula & $\begin{array}{l}\text { PDF Card } \\
\text { Number }\end{array}$ & $\begin{array}{c}\text { Common } \\
\text { Phase Name }\end{array}$ \\
\hline \multirow{2}{*}{ U-3 } & \multirow{2}{*}{7 July 2010} & Unheated & $\mathrm{UO}_{2}$ & $01-075-0420$ & Uraninite \\
\hline & & $\mathrm{UO}_{2} / \mathrm{UO}_{3} \cdot 2 \mathrm{H}_{2} \mathrm{O}$ & $\mathrm{UO}_{3} \cdot 2 \mathrm{H}_{2} \mathrm{O}$ & $00-043-0364$ & Metaschoepite \\
\hline \multirow{2}{*}{ U-1 } & \multirow{2}{*}{7 July 2010} & Heated & $\mathrm{UO}_{2}$ & $01-075-0420$ & Uraninite \\
\hline & & $\mathrm{UO}_{2} / \mathrm{UO}_{3} \cdot 2 \mathrm{H}_{2} \mathrm{O}$ & $\mathrm{UO}_{3} \cdot 2 \mathrm{H}_{2} \mathrm{O}$ & $00-043-0364$ & Metaschoepite \\
\hline \multirow{6}{*}{ S-start } & \multirow{6}{*}{7 July 2010} & & $\mathrm{UO}_{2}$ & $01-075-0420$ & Uraninite \\
\hline & & Unheated KW & $\mathrm{UO}_{3} \cdot 2 \mathrm{H}_{2} \mathrm{O}$ & $00-043-0364$ & Metaschoepite \\
\hline & & Container & $\mathrm{FeO}(\mathrm{OH})$ & $01-073-6522$ & Goethite \\
\hline & & Sludge & $\mathrm{Fe}_{2} \mathrm{O}_{3}$ & $01-073-2234$ & Hematite \\
\hline & & Simulant & $\mathrm{Al}(\mathrm{OH})_{3}$ & $01-070-2038$ & Gibbsite \\
\hline & & & $\mathrm{Na}_{0.25} \mathrm{Ca}_{0.71}\left(\mathrm{Al}_{2} \mathrm{Si}_{2} \mathrm{O}_{8}\right)$ & $01-078-2330$ & Anorthite \\
\hline \multirow{8}{*}{ S-6 } & \multirow{8}{*}{8 July 2010} & \multirow{8}{*}{$\begin{array}{l}\text { Heated KW } \\
\text { Container } \\
\text { Sludge } \\
\text { Simulant }\end{array}$} & $\mathrm{UO}_{2}$ & $01-075-0420$ & Uraninite \\
\hline & & & $\mathrm{UO}_{3} \cdot 2 \mathrm{H}_{2} \mathrm{O}$ & 00-043-0364 & Metaschoepite \\
\hline & & & $\mathrm{FeO}(\mathrm{OH})$ & $01-073-6522$ & Goethite \\
\hline & & & $\mathrm{Fe}_{2} \mathrm{O}_{3}$ & $01-073-2234$ & Hematite \\
\hline & & & $\mathrm{Al}(\mathrm{OH})_{3}$ & $01-070-2038$ & Gibbsite \\
\hline & & & $\mathrm{KAlSi}_{3} \mathrm{O}_{8}$ & $01-076-1239$ & Microcline \\
\hline & & & $\mathrm{Na}_{0.25} \mathrm{Ca}_{0.71}\left(\mathrm{Al}_{2} \mathrm{Si}_{2} \mathrm{O}_{8}\right)$ & $01-078-2330$ & Anorthite \\
\hline & & & $\mathrm{Ca}_{0.4} \mathrm{Al}_{0.98} \mathrm{Si}_{5.03} \mathrm{O}_{12}\left(\mathrm{H}_{2} \mathrm{O}\right)_{3.57}$ & $01-078-1765$ & Mordenite \\
\hline
\end{tabular}

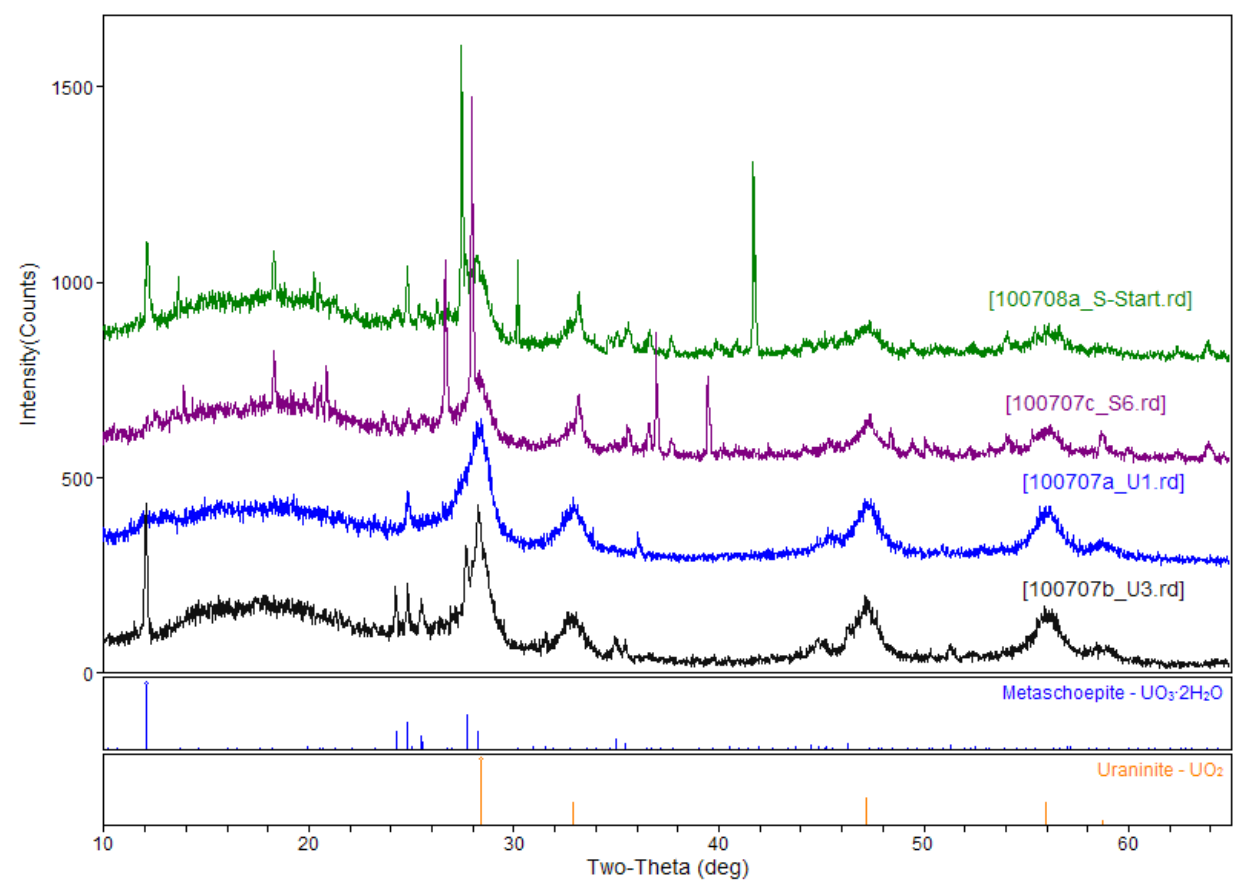

Figure A.1. Overlay of XRD Scans for Samples: Starting (S-Start KW Sim, unheated), S6 (KW Sim, heated), $\mathrm{U} 1\left(\mathrm{UO}_{2} / \mathrm{UO}_{3} \cdot 2 \mathrm{H}_{2} \mathrm{O}\right.$, heated), and $\mathrm{U} 3\left(\mathrm{UO}_{2} / \mathrm{UO}_{3} \cdot 2 \mathrm{H}_{2} \mathrm{O}\right.$, unheated $)$ 


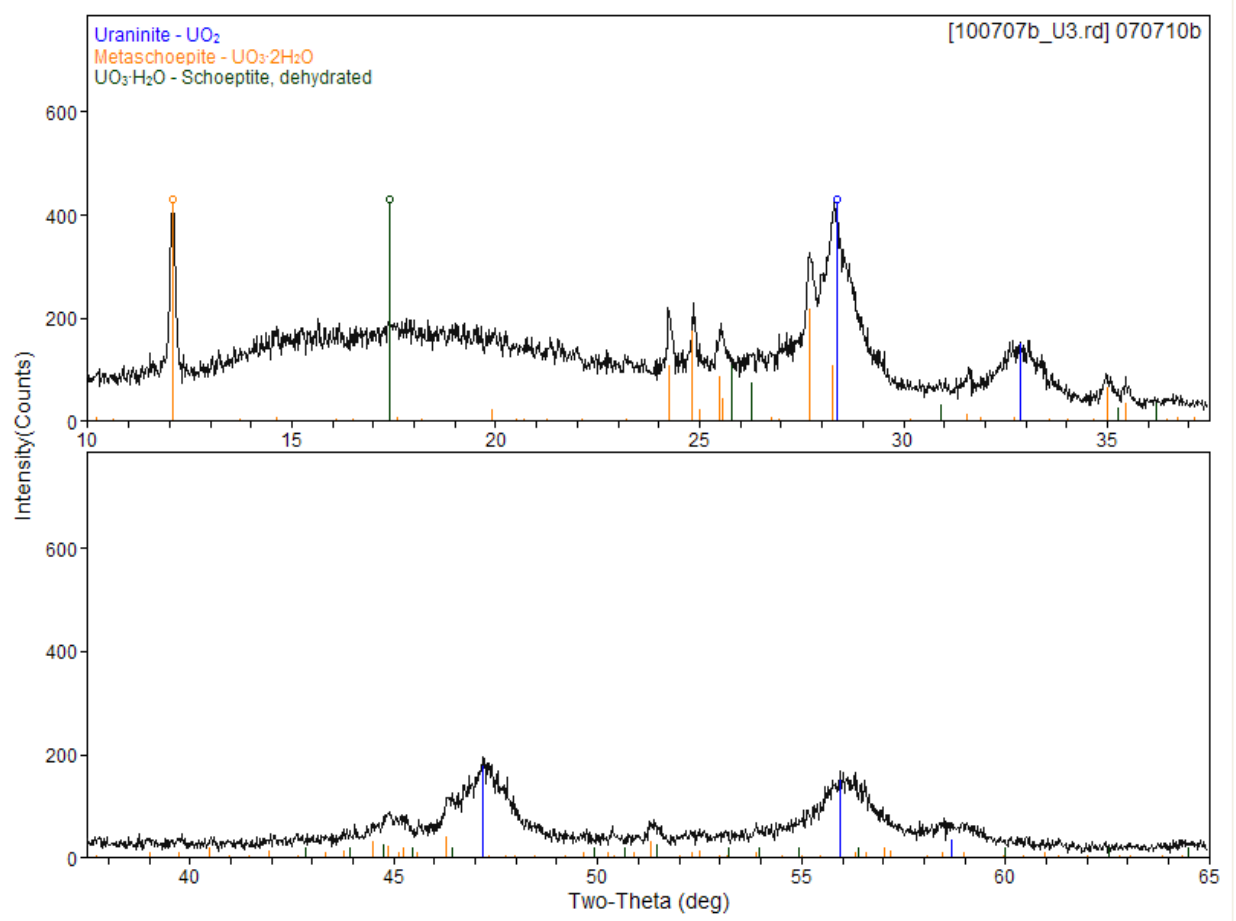

Figure A.2. XRD Scan of Sample U-3, Unheated $\mathrm{UO}_{2} / \mathrm{UO}_{3} \cdot 2 \mathrm{H}_{2} \mathrm{O}$ Mixture

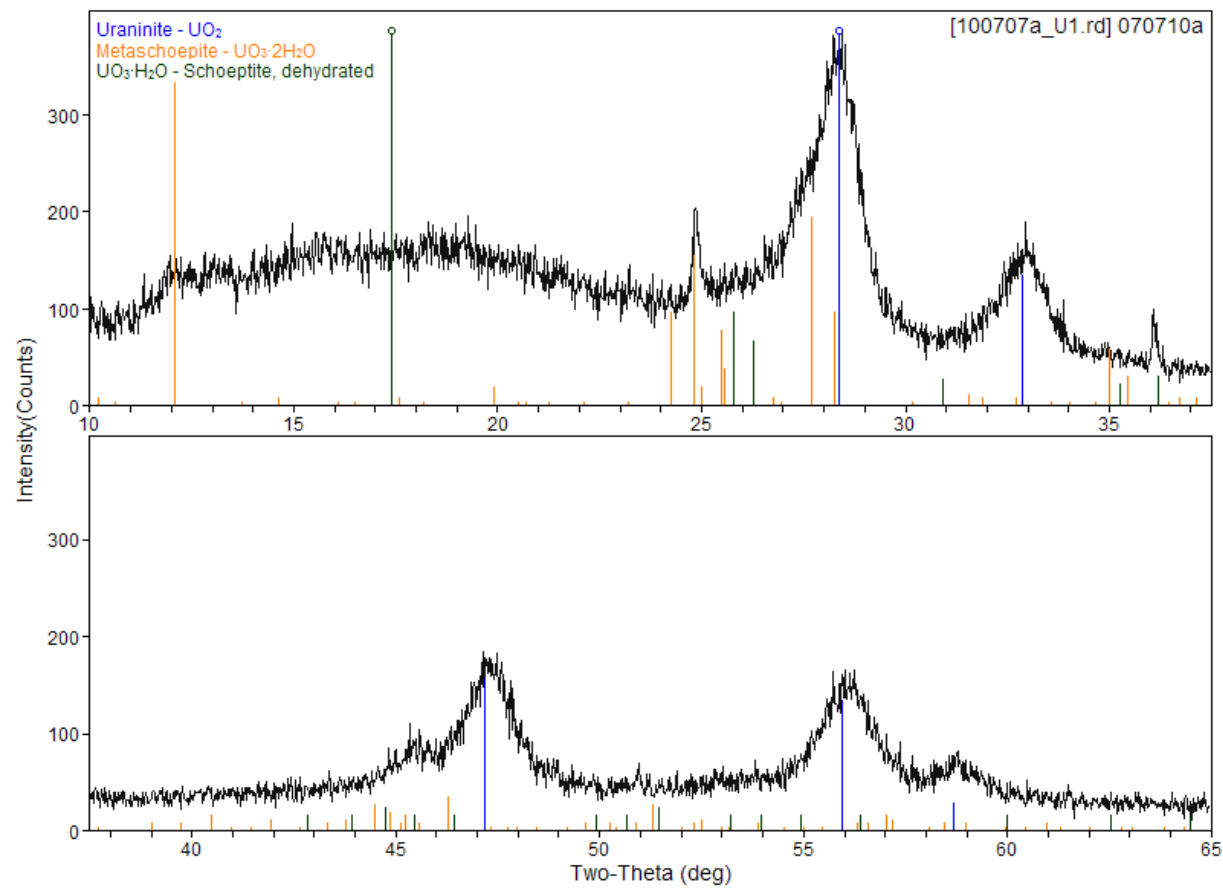

Figure A.3. XRD Scan of Sample U-1, Heated $\mathrm{UO}_{2} / \mathrm{UO}_{3} \cdot 2 \mathrm{H}_{2} \mathrm{O}$ Mixture 


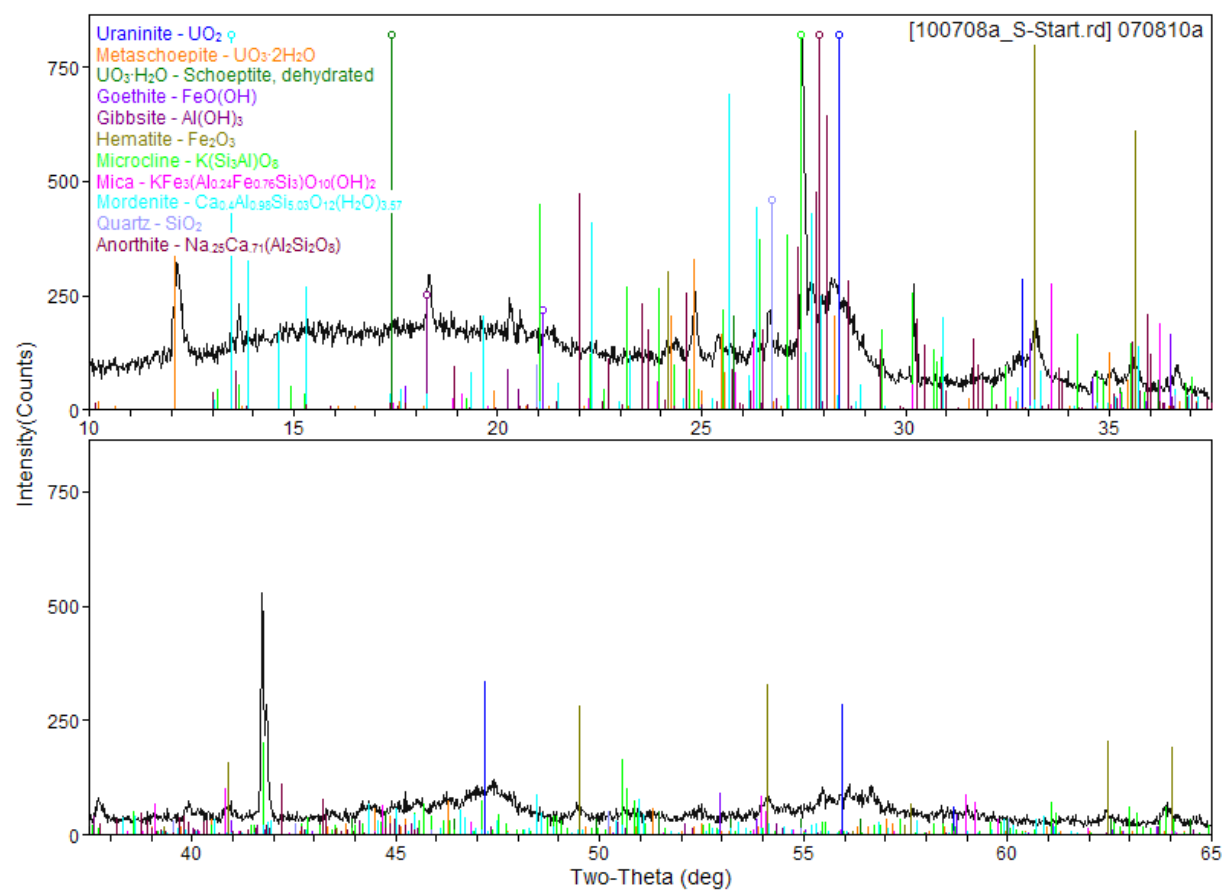

Figure A.4. XRD Scan of Sample S-start, Unheated KW Container Sludge Simulant

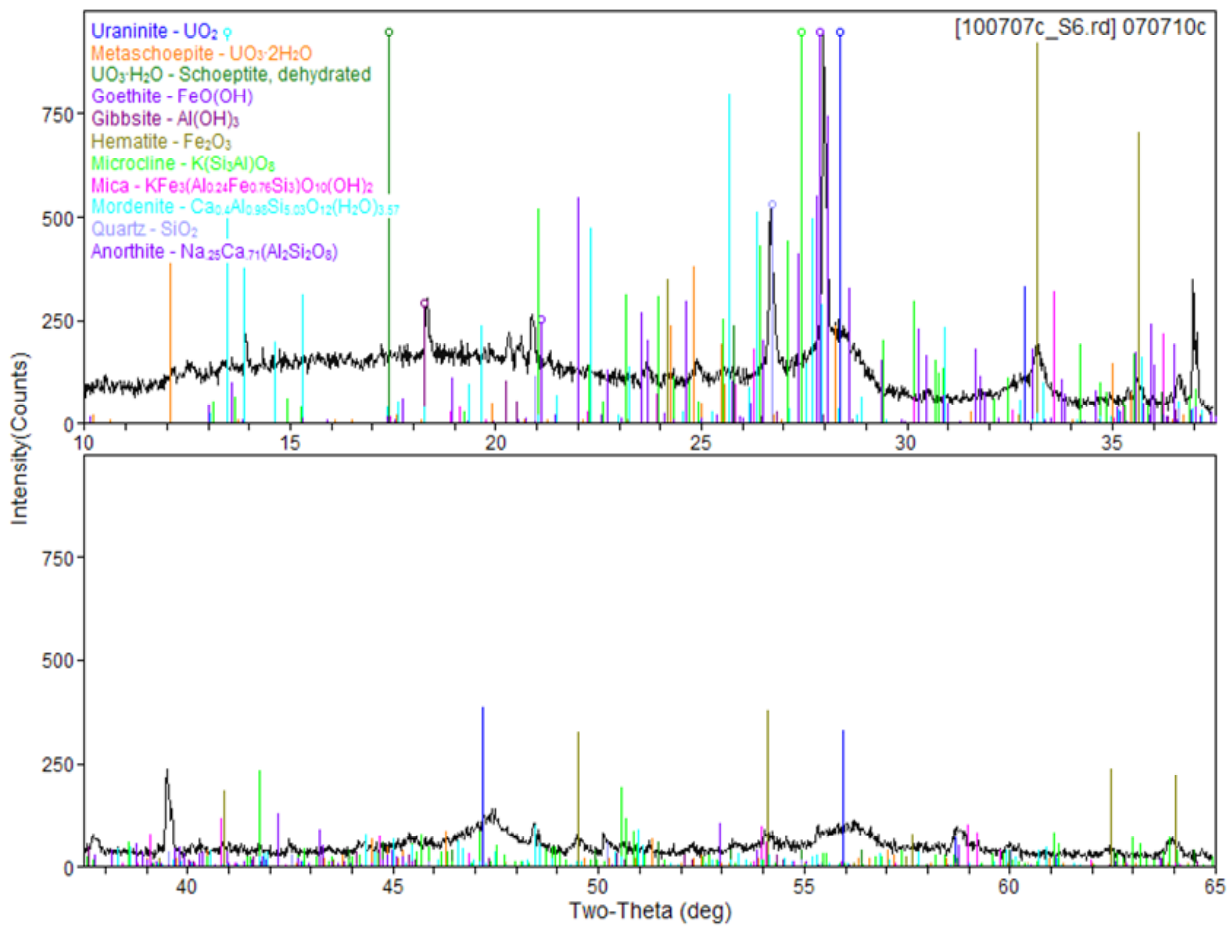

Figure A.5. XRD Scan of Sample S-6, Heated KW Container Sludge Simulant 


\section{Theta Calibration Report}

The XRD instrument performed within acceptable limits in that the difference between the measured and expected peak location, $\Delta \Theta$, for the silicon standard was $<0.06^{\circ}$ (Figure A.6).

File name :[si_640_std_071210a.raw] Si standard 640

Reference Lines $=00-027-1402>$ Silicon $-\mathrm{Si}$

Two-Theta Range of Fit $=27.0 / 29.0(\mathrm{deg})$

2T(r) 2T(o) Delta $\mathrm{d}(\mathrm{r}) \quad \mathrm{d}(\mathrm{o}) \quad$ Del-d $\quad \mathrm{I} \%$

$\begin{array}{llllllll}28.443 & 28.495 & -0.053 & 3.1355 & 3.1298 & 0.0057 & 100.0\end{array}$

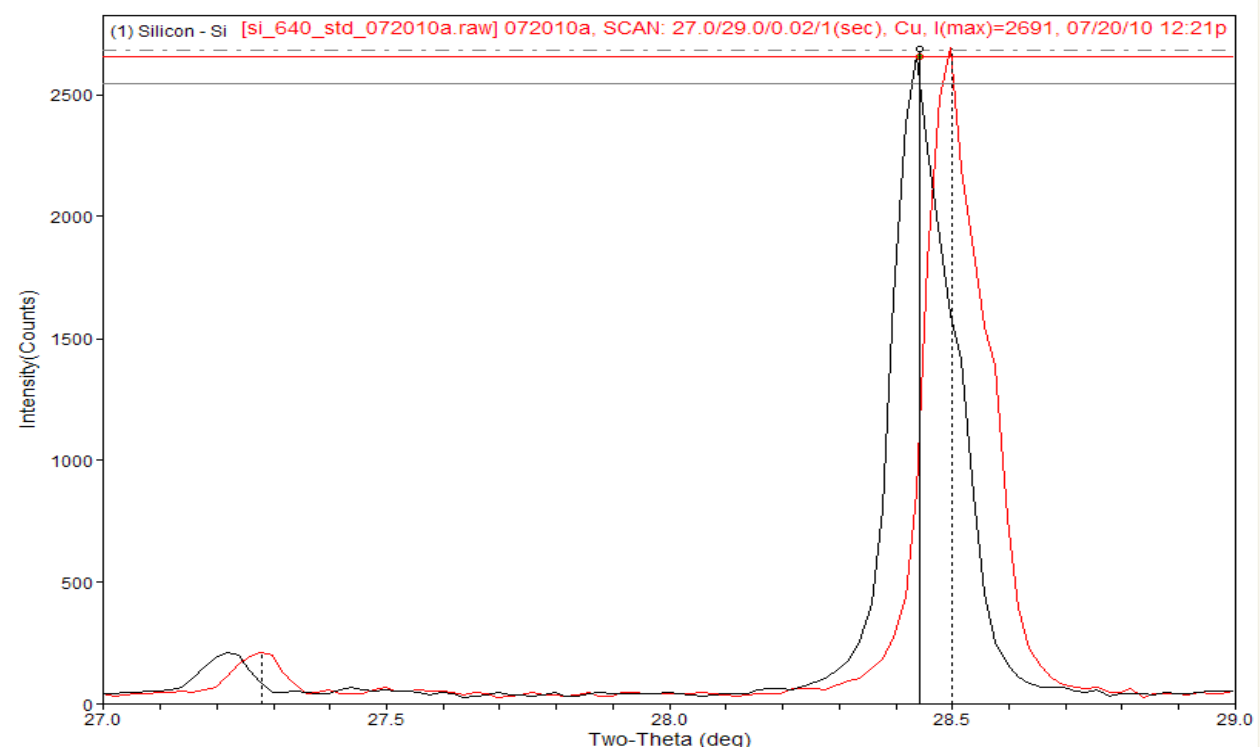

Figure A.6. XRD of Si NIST 640 SRM, 28.443 Line Performed on 071210 


\section{Appendix B}

\section{Supporting Calculations for Evaluation of Corrosion Based Expansion Factors}

This appendix, prepared by Andy Schmidt, provides support to Section 4.0 of this report and includes calculations to:

1. Reproduce the corrosion-based expansion factors using the approach summarized in Rev. 14B of the Sludge Technical Databook (Schmidt 2010) and the contributing technical bases documents.

2. Provide a proposed updated expansion factor calculation methodology using data collected since 2003 and results of recent uranium oxidation studies.

3. Evaluate revised expansion-factor predictions in terms of void fraction of water and settledsludge density at end-state conditions.

4. Provide summary tables on sludge expansion for

- $\quad$ settler sludge (SCS-CON-230)

- KW-originating container sludge (SCS-CON-210 and -220)

- KE-originating container sludge (SCS-CON-240, 250, and 260). 


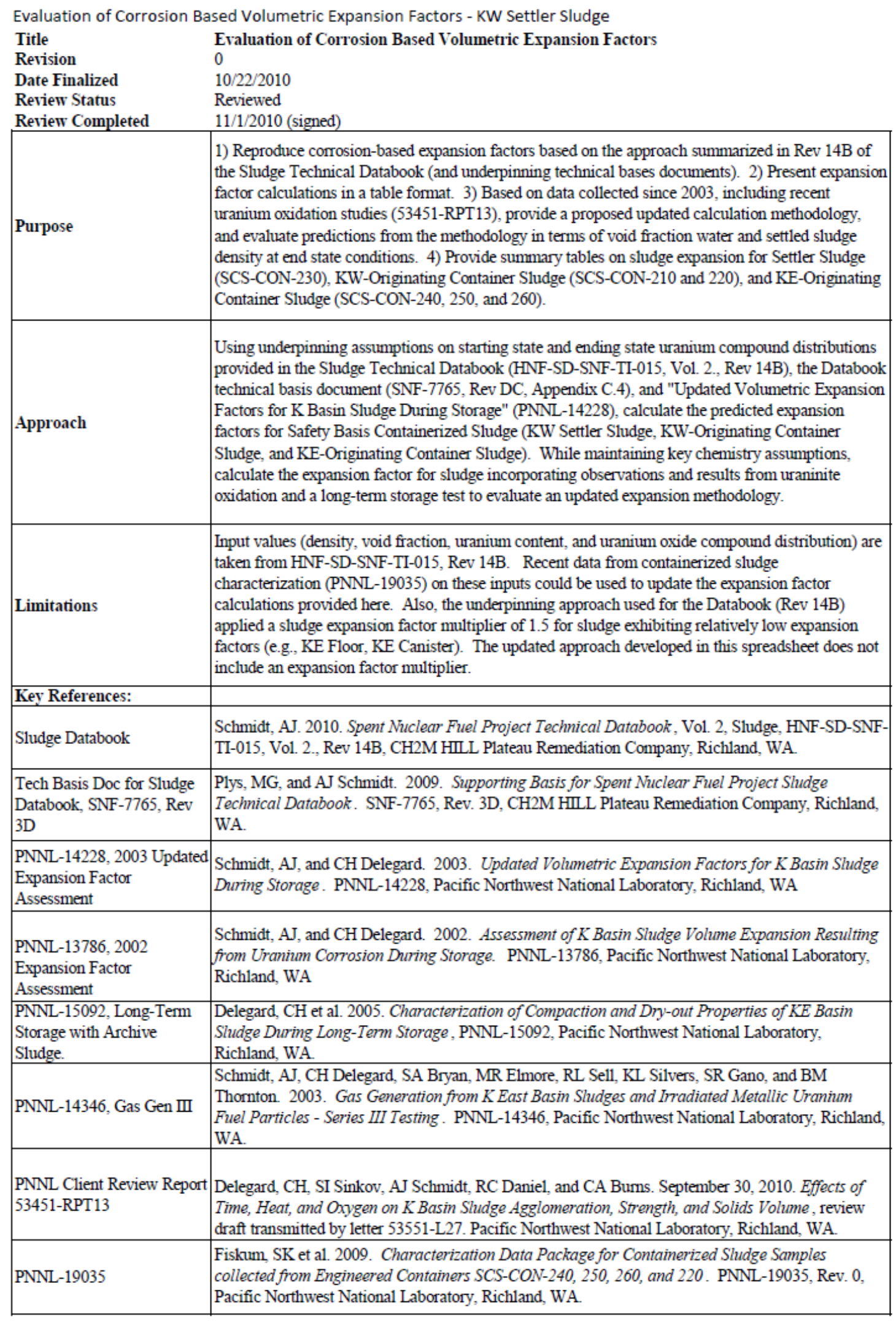


Calc Approach for Expansion Factors used in Sludge Databook (HNF-SD-SNF-TI-015, Vol 2 Rev 14B)

Parameter inputs, for Safety Basis KW Settler Sludge: Sludge Databook, Rev 14B, Table 5.2

KW Settler Tank is a 50/50 Vol Mix of KE and KW Canister Sludge (Databook 14B, Table 5.1).

Starting State U Oxide Composition, U mol basis mixture. (Basis: SNF-7765 Rev3D Sec. C4; PNNL-14228, p. 2.9)

\begin{tabular}{lccc}
$\mathrm{KE}$ Can \& Floor Sludge & $1 / 3 \mathrm{UO}_{2}+1 / 3 \mathrm{U}_{4} \mathrm{O}_{9}+1 / 3 \mathrm{UO}_{3} \cdot 2 \mathrm{H}_{2} \mathrm{O}$ \\
KW Canister Sludge & $1 / 2 \mathrm{UO}_{2}+1 / 2 \mathrm{U}_{4} \mathrm{O}_{9}$ & \\
& \multicolumn{4}{c}{} \\
& $\mathrm{UO}_{2}$ & $\mathrm{UO}_{225}$ & $\mathrm{UO}_{3} \cdot 2 \mathrm{H}_{2} \mathrm{O}$ \\
KE Can \& Floor Sludge & 0.333 & 0.333 & 0.333 \\
KW Canister Sludge & 0.5 & 0.5 &
\end{tabular}

$\mathrm{KE}$ canister \& $\mathrm{KE}$ floor sludge starting state is an equal uranium mole fraction of these three uranium compounds

KW canister sludge starting state is an equal uranium mole fraction of these two uranium compounds

End State (partially oxic storage) all uranium compounds (Basis: SNF-7765 Rev 3D, Sec. C4; PNNL-14228)

All $\mathrm{U}$ oxides \& $\mathrm{U}$ metal $\quad 1 / 2 \mathrm{U}_{4} \mathrm{O}_{9}+1 / 2 \mathrm{UO}_{3} \cdot 2 \mathrm{H}_{2} \mathrm{O}$

All U oxides \& U metal $\quad 0.5 \quad 0.5$

Volume fraction water $\quad 0.75$

To derive the starting state fraction of uranium oxide in Settler sludge, first it is necessary to account for fraction of $U$ oxide from KE Canister vs. KW Canister.

\begin{tabular}{|c|c|c|c|c|}
\hline \multirow[b]{3}{*}{$\mathrm{U}$ total, $\mathrm{g} / \mathrm{cm}^{3}$} & & & Settler Sludge & \multirow{6}{*}{$\begin{array}{l}\text { (Databook, Rev 14B, Table 4.3) } \\
\text { (Databook, Rev 14B, Table 4.4) } \\
\text { (Calculated by difference) }\end{array}$} \\
\hline & SB KW Can & SB KE Can & $50 / 50 \mathrm{Vol} \mathrm{Mix}$ & \\
\hline & 2.7 & 1.4 & 2.1 & \\
\hline $\mathrm{U}$ metal, $\mathrm{g} / \mathrm{cm}^{3}$ & 0.2 & 0.125 & 0.16 & \\
\hline \multirow{2}{*}{$\begin{array}{l}\quad \mathrm{U} \text { as oxide, } \mathrm{g} / \mathrm{cm}^{3} \\
\text { Source of U Oxide } \\
\text { (Fraction) in } 50 / 50 \mathrm{mix} \\
\text { (Settler Sludge }\end{array}$} & 2.5 & 1.275 & 1.9 & \\
\hline & 0.66 & 0.34 & 1.0 & \\
\hline
\end{tabular}

Note: Molecular weights rounded to 3 sig figs; Particle densities are from PNNL-14228

Calculation/Data Table for SB KW Settler Sludge (Sludge Databook Rev 14B Basis, Table 5.2) 
Evaluation of Corrosion Based Volumetric Expansion Factors - KW Settler Sludge

Sludge Type Input Parameters

Sludge Type

KW Settler Sludge, Safety Basis (SCS-CON-230)

\begin{tabular}{|l|c|}
\hline Settled density, $\mathrm{g} / \mathrm{cm}^{3}$ & 3.2 \\
\hline Volume fraction water & 0.7 \\
\hline $\mathrm{U}$ total, $\mathrm{g} / \mathrm{cm}^{3}$ & 2.1 \\
\hline $\mathrm{U}$ metal, $\mathrm{g} / \mathrm{cm}^{3}$ & 0.16 \\
\hline
\end{tabular}

Uranium Compounds, Starting State and End State Assignments

\begin{tabular}{|l|c|c|c|c|}
\hline \multirow{2}{*}{ Uranium and Oxides } & $\begin{array}{c}\text { Molecular } \\
\text { weight }\end{array}$ & $\begin{array}{c}\text { Particle } \\
\text { density }\end{array}$ & $\begin{array}{c}\text { Ratio of U oxide compounds, } \\
\text { on a U mol basis }\end{array}$ \\
\cline { 2 - 5 } & $\mathrm{g}$ & $\mathrm{g} / \mathrm{cm}^{3}$ & Starting State & End State \\
\hline $\mathrm{U}_{\mathrm{n} \text { metal }}$ & 238 & 19 & NA & 0.00 \\
\hline $\mathrm{UO}_{2}$ & 270 & 10.95 & 0.44 & 0.00 \\
\hline $\mathrm{UO}_{2.25}\left(\mathrm{U}_{4} \mathrm{O}_{9}\right)$ & 274 & 11.32 & 0.44 & 0.50 \\
\hline $\mathrm{UO}_{3}-2 \mathrm{H}_{2} \mathrm{O}$ & 322 & 4.87 & 0.11 & 0.50 \\
\hline
\end{tabular}

Mass and Volume Balance Based on Solids in $1 \mathrm{~cm}^{3}$ Starting State Settled Sludge

\begin{tabular}{|c|c|c|c|c|}
\hline \multirow{2}{*}{ Species } & \multicolumn{2}{|c|}{ Starting State } & \multicolumn{2}{|c|}{ End State } \\
\hline & Mass, g & Volume, $\mathrm{cm}^{3}$ & Mass, $g$ & Volume, $\mathrm{cm}^{3}$ \\
\hline U metal & 0.16 & 0.0084 & 0 & 0 \\
\hline $\mathrm{UO}_{2}$ & 0.98 & 0.089 & 0 & 0 \\
\hline $\mathrm{UO}_{2.25}\left(\mathrm{U}_{4} \mathrm{O}_{9}\right)$ & 0.99 & 0.087 & 1.21 & 0.11 \\
\hline $\mathrm{UO}_{3} \cdot 2 \mathrm{H}_{2} \mathrm{O}$ & 0.30 & 0.061 & 1.42 & 0.29 \\
\hline Non-U Solids & 0.077 & 0.054 & 0.077 & 0.054 \\
\hline Total Solids & 2.50 & 0.300 & 2.71 & 0.45 \\
\hline \multicolumn{5}{|c|}{ End State Settled Sludge Volume } \\
\hline Volume fraction water & 0.75 & & & \\
\hline Sludge solids, $\mathrm{cm}^{3}$ & 0.45 & & & \\
\hline Settled sludge vol, $\mathrm{cm}^{3}$ & 1.81 & (Also equ & volume ex & sion factor) \\
\hline Settled density, $\mathrm{g} / \mathrm{cm}^{3}$ & 2.25 & & & \\
\hline
\end{tabular}

Cross Checks on Settler Sludge

Starting State particle density, $\mathrm{g} / \mathrm{cm}^{3}$

End State particle density, $\mathrm{g} / \mathrm{cm}^{3}$

9.52 (reasonably consistent with PNNL-14228)

Density check on non- $\mathrm{U}$ solids, $\mathrm{g} / \mathrm{cm}^{3}$

6.60 (consistent with PNNL-14228)

1.42 (low, but reasonable)
Use for

Table 4.1

53451-RPT13

Comparison of approach above with Databook (Rev 14B) Values

Settler $=50 / 50 \mathrm{Vol}$ mix of KE/KW Canister Sludge.

Note: because of the relatively low sludge expansion for $\mathrm{KE}$ Canister sludge, an expansion factor multiplier of 1.5

was used for the value provided in the Databook (Rev 14B); see Table 2.1, page 2.3 of PNNL-14228.

Cross Check on Databook Values for Expansion Factor (EF) (Rev 14B, Table 4-6)

Exp Factor (EF) Databook, Table 4-6

$\begin{array}{ccc}\text { KW Can } & \mathrm{KE} \mathrm{Can}^{(\mathrm{a})} & 50 / 50 \mathrm{Mix}^{(\mathrm{b})} \\ 2.4 & 1.33 & 1.87 \\ 1 & 1.5 & \mathrm{NA} \\ 2.4 & 1.22 & 1.81\end{array}$

Exp Factor w/out multiplier

1.22

1.81

(a) Note: $\mathrm{EF}$ for $\mathrm{KE}$ Canister sludge given in the Databook (Rev 14B) includes a $1.5 \mathrm{X}$ multiplier.

(b) Calculated as 50/50 mix of $\mathrm{KE} / \mathrm{KW}$ Canister sludge

Conclusion: Approach in Table $(E F=1.81)$ is consistent with Databook, Rev 14B $(E F=1.81)$. 
Evaluation of Corrosion Based Volumetric Expansion Factors - KW Settler Sludge

Alternative Approach for Expansion Factors (Updated)

Key Assumptions based on uraninite oxidation (53451-RPT13) and long-term settling (PNNL-15092)

1) U metal corrodes to end state uranium oxide mixture and volume frac water as given in PNNL-14228.

2) Oxidation of uranium oxides does not result in growth of settled sludge volume.

3) Therefore, only U metal oxidation gives volume growth and must be accounted for in expansion factors.

4) Need to account for fraction of U oxide from both KE Can and KW Can for starting state mass balance.

Calculation/Data Table for SB KW Settler Sludge (Updated Approach)

Sludge Type Input Parameters

\begin{tabular}{|l|l|}
\hline Sludge Type & KW Settler Sludge, Safety Basis (SCS-CON-230)
\end{tabular}

\begin{tabular}{|l|c|}
\hline Settled density, $\mathrm{g} / \mathrm{cm}^{3}$ & 3.2 \\
\hline Volume fraction water & 0.7 \\
\hline $\mathrm{U}$ total, $\mathrm{g} / \mathrm{cm}^{3}$ & 2.1 \\
\hline $\mathrm{U}$ metal, $\mathrm{g} / \mathrm{cm}^{3}$ & 0.16 \\
\hline
\end{tabular}

Uranium Compounds, Starting State and End State Assignments

\begin{tabular}{|l|c|c|c|c|}
\hline \multirow{2}{*}{ Uranium and Oxides } & $\begin{array}{c}\text { Molecular } \\
\text { Weight }\end{array}$ & $\begin{array}{c}\text { Particle } \\
\text { Density }\end{array}$ & \multicolumn{2}{|c|}{$\begin{array}{c}\text { Ratio of U oxides compounds, } \\
\text { on a U mol basis }\end{array}$} \\
\cline { 2 - 5 } & $\mathrm{g}$ & $\mathrm{g} / \mathrm{cm}^{3}$ & Starting State & End State \\
\hline $\mathrm{U}$ metal & 238 & 19 & NA & 0.00 \\
\hline $\mathrm{UO}_{2}$ & 270 & 10.95 & 0.44 & 0.00 \\
\hline $\mathrm{UO}_{2.25}\left(\mathrm{U}_{4} \mathrm{O}_{9}\right)$ & 274 & 11.32 & 0.44 & 0.50 \\
\hline $\mathrm{UO}_{3} \cdot 2 \mathrm{H}_{2} \mathrm{O}$ & 322 & 4.87 & 0.11 & 0.50 \\
\hline
\end{tabular}

Mass and Volume Balance Based on Solids in $1 \mathrm{~cm}^{3}$ Starting State Settled Sludge

\begin{tabular}{|l|c|c|c|c|}
\multirow{2}{*}{ Species } & \multicolumn{2}{|c|}{ Starting State } & \multicolumn{2}{c|}{ End State } \\
\cline { 2 - 5 } & Mass, $\mathrm{g}$ & Volume, $\mathrm{cm}^{3}$ & Mass, $\mathrm{g}$ & Volume, $\mathrm{cm}^{3}$ \\
\hline $\mathrm{U}$ metal & 0.16 & 0.0084 & 0 & 0 \\
\hline $\mathrm{UO}_{2}$ & 0.98 & 0.089 & 0 & 0 \\
\hline $\mathrm{UO}_{2.25}\left(\mathrm{U}_{4} \mathrm{O}_{9}\right)$ & 0.99 & 0.087 & 1.21 & 0.11 \\
\hline $\mathrm{UO}_{3}-2 \mathrm{H}_{2} \mathrm{O}$ & 0.30 & 0.061 & 1.42 & 0.29 \\
\hline Non-U Solids & 0.077 & 0.054 & 0.077 & 0.054 \\
\hline Total Solids & 2.50 & 0.300 & 2.71 & 0.45 \\
\hline
\end{tabular}

End State Settled Sludge Volume ${ }^{(\mathrm{b})}$

\begin{tabular}{|l|l}
\hline Expansion U metal ${ }^{(\mathrm{c})}, \mathrm{cm}^{3}$ & 0.13 \\
\hline
\end{tabular}

\begin{tabular}{|l|l|l}
\hline Settled sludge vol., $\mathrm{cm}^{3}$ & 1.13 & (Also equals volume expansion factor)
\end{tabular}

Calc. Vol. Frac. Water

0.60

Settled density, $\mathrm{g} / \mathrm{cm}^{3}$

3.00

(a) Starting state U oxide ratio based on HNF-SD-SNF-TI-015, Vol 2 Rev 14B. Future updates should consider use of measured $U$ oxide ratios, based on validated characterization data.

(b) Proposed approach assumes further oxidation and hydration of uranium oxides do not change end state settled volume.

(c) Volume expansion from U metal oxidation is addressed using conservative theoretical expansion factor approach. Every gram of $U$ metal in starting state sludge creates $0.8 \mathrm{~cm}^{3}$ increase in end state settled sludge volume. 
Evaluation of Corrosion Based Volumetric Expansion Factors - KW Settler Sludge

Page 5 of 6

Basis for U Metal Expansion Factor (Sludge Databook Rev 14B Basis)

\begin{tabular}{|c|c|c|c|c|}
\hline Sludge Type & \multicolumn{4}{|c|}{ U MetalFuel Piece, Safety Basis } \\
\hline Property/Parameter & Settled Basis & & & \\
\hline Density, $\mathrm{g} / \mathrm{cm}^{3}$ & \multirow{2}{*}{$\begin{array}{c}10.5 \\
0.4\end{array}$} & & & \\
\hline Vol Frac Water & & & & \\
\hline $\mathrm{U}$ total, $\mathrm{g} / \mathrm{cm}^{3}$ & 9.4 & & & \\
\hline U metal, $\mathrm{g} / \mathrm{cm}^{3}$ & 9.4 & & & \\
\hline \multirow[t]{2}{*}{ Uranium and Oxides } & $\begin{array}{c}\text { Molecular } \\
\text { Weight }\end{array}$ & $\begin{array}{l}\text { Particle } \\
\text { Density }\end{array}$ & \multicolumn{2}{|c|}{$\begin{array}{l}\text { Ratio of } \mathrm{U} \text { oxides compounds, } \\
\text { on a } \mathrm{U} \text { mol basis }\end{array}$} \\
\hline & $\mathrm{g}$ & $\mathrm{g} / \mathrm{cm}^{3}$ & Starting State & End State \\
\hline U metal & 238 & 19 & 1 & 0.00 \\
\hline $\mathrm{UO}_{2}$ & 270 & 10.95 & 0.00 & 0.00 \\
\hline $\mathrm{UO}_{2.25}\left(\mathrm{U}_{4} \mathrm{O}_{9}\right)$ & 274 & 11.32 & 0.00 & 0.50 \\
\hline $\mathrm{UO}_{3} \cdot 2 \mathrm{H}_{2} \mathrm{O}$ & 322 & 4.87 & 0.00 & 0.50 \\
\hline \multicolumn{5}{|c|}{ Mass and Volume Balance Based on Solids in $1 \mathrm{~cm}^{3}$ Starting State Settled Sludge } \\
\hline \multirow{2}{*}{ Species } & \multicolumn{2}{|c|}{ Starting State } & \multicolumn{2}{|c|}{ End State } \\
\hline & Mass, $\mathrm{g}$ & Volume, $\mathrm{cm}^{3}$ & Mass, $\mathrm{g}$ & Volume, $\mathrm{cm}^{3}$ \\
\hline U metal & 9.40 & 0.4947 & 0 & 0 \\
\hline $\mathrm{UO}_{2}$ & 0.00 & 0.000 & 0 & 0 \\
\hline $\mathrm{UO}_{2.25}\left(\mathrm{U}_{4} \mathrm{O}_{9}\right)$ & 0.00 & 0.000 & 5.41 & 0.48 \\
\hline $\mathrm{UO}_{3} \cdot 2 \mathrm{H}_{2} \mathrm{O}$ & 0.00 & 0.000 & 6.36 & 1.31 \\
\hline Non-U Solids (Zirc Clad) & 0.700 & 0.105 & 0.70 & 0.105 \\
\hline Total Solids & 10.10 & 0.600 & 12.47 & 1.89 \\
\hline \multicolumn{2}{|c|}{ End State Settled Sludge Volume } & & & \\
\hline Volume frac water & 0.75 & & & \\
\hline Sludge solids, $\mathrm{cm}^{3}$ & 1.89 & & & \\
\hline Settled sludge vol, $\mathrm{cm}^{3}$ & 7.56 & \multicolumn{3}{|c|}{ (Also equals volume expansion factor) } \\
\hline Sludge vol w/out $\mathrm{Zr}, \mathrm{cm}^{3}$ & 7.13 & & & \\
\hline $\mathrm{mL}$ settled sludge/g $\mathrm{U}_{\text {metal }}$ & 0.76 & & & \\
\hline
\end{tabular}

\begin{tabular}{|c|c|}
\hline \multicolumn{2}{|l|}{ Cross Check from Databook (Rev 14B) U metal Expansion Factor: } \\
\hline Table 4.6 Databook Expansion Factor for SB Fuel Piece sludge: & 7.5 \\
\hline U metal in Fuel Piece Sludge, Table 4.4a of Databook & $9.4 \mathrm{~g} / \mathrm{cm}^{3}$ \\
\hline Projected volume of sludge per g/U metal & $0.798 \mathrm{~cm}^{3} / \mathrm{g}$ \\
\hline $\begin{array}{l}\text { Conclusion: Approach above is consistent with Databook } \\
\text { Round up to } 0.8 \mathrm{~cm}^{3} / \mathrm{g} \mathrm{U} \text { metal }\end{array}$ & \\
\hline
\end{tabular}


Evaluation of Corrosion Based Volumetric Expansion Factors - KW Settler Sludge

Page 6 of 6

Cross Check on U metal expansion, based on Gas Gen III, PNNL-14346, Section 7.7

Crushed U metal Fuel Particles were reacted to extinction (Tests M500 and Mid 80L Comp)

Settled volume of resulting uranium oxide corrosion products was measured.

Determine volume of settled sludge generated per gram of uranium metal reacted.

Test

Particles added, $g$

Fraction U metal

g U metal

SNF Mid 80- SNF M500

$\mathrm{g}$ U oxide \& $\mathrm{Zr}$ clad added

L Comp

$17.02 \quad 7.95$

$0.93 \quad 0.742$

$15.8286 \quad 5.8989$

Data from Table 7.10 of PNNL-14346

$1.1914 \quad 2.051$

Page 5.15, PNNL-14346

Post Test vol, $\mathrm{cm}^{3}$

8.4

4.2

(vol contributed by this mass neglected in calc below)

Sludge Vol, $\mathrm{cm}^{3} / \mathrm{g} \mathrm{U}_{\text {metal }}$

0.53

Data from Table 7.10 of PNNL-14346

(adjusted to include mass left in rxt vessel)

0.71 (neglects contribution of initial U oxide)

Conclusion: Use of factor of $0.8 \mathrm{~cm}^{3}$ sludge $/ \mathrm{g}_{\text {metal }}$ is reasonably consistent with Gas Gen III data. 


\begin{tabular}{|c|c|}
\hline $\begin{array}{l}\text { Title } \\
\text { Revision } \\
\text { Date Finalized } \\
\text { Review Status } \\
\text { Date Reviewed }\end{array}$ & $\begin{array}{l}\text { Evaluation of Corrosion Based Volumetric Expansion Factors } \\
0 \\
10 / 22 / 2010 \\
\text { Reviewed } \\
11 / 1 / 2010 \text { (signed) }\end{array}$ \\
\hline Purpose/Approach & $\begin{array}{l}\text { Apply approach developed for Settler Sludge Expansion Factor to Calculate the } \\
\text { Expansion Factor of KW Containerized Sludge, with appropriate input values from } \\
\text { the Sludge Databook (Rev 14B). }\end{array}$ \\
\hline
\end{tabular}

Calculation Approach for Expansion Factors used in Sludge Databook (HNF-SD-SNF-TI-015, Vol 2 Rev 14B) Parameter inputs for KW Container Sludge: Sludge Databook, Rev 14 B, Table 5.2

Starting State U Oxide Composition, U mol basis mixture (Basis: SNF-7765 Rev 3D Sec. 4, PNNL-14228).

$$
\begin{aligned}
& 1 / 3 \mathrm{UO}_{2}+1 / 3 \mathrm{U}_{4} \mathrm{O}_{0}+1 / 3 \mathrm{UO}_{3} \cdot 2 \mathrm{H}_{2} \mathrm{O} \quad \mathrm{KE} \text { canister \& } \mathrm{KE} \text { floor sludge starting state is an } \\
& \mathrm{KE} \text { Can \& Floor Sludge } \quad \mathrm{UO}_{2} \quad \mathrm{UO}_{2.25} \quad \mathrm{UO}_{3} \cdot 2 \mathrm{H}_{2} \mathrm{O} \text { equal uranium mole fraction of these three uranium } \\
& \begin{array}{llll}
0.333 & 0.333 & 0.333 & \text { compounds }
\end{array} \\
& \begin{array}{lcll}
\text { KW Canister Sludge } & 0.5 & 0.5 & \begin{array}{l}
\text { KW canister sludge starting state is an equal } \\
\text { uranium mole fraction of these two uranium } \\
\text { compounds }
\end{array}
\end{array}
\end{aligned}
$$

End State (partially oxic storage) all uranium compounds (Basis: SNF-7765 Rev 3D, Sec. 4; PNNL-14228)

$$
\begin{array}{lccc} 
& 1 / 2 \mathrm{U}_{4} \mathrm{O}_{9}+1 / 2 & \mathrm{UO}_{3} \cdot 2 \mathrm{H}_{2} \mathrm{O} & \\
\mathrm{UO}_{2} & \mathrm{UO}_{2.25} & \mathrm{UO}_{3} \cdot 2 \mathrm{H}_{2} \mathrm{O}
\end{array}
$$

Volume fraction water $\quad 0.75$

To determine the starting state $\mathrm{U}$ oxide ratios for the sludge contained within a particular Engineered Container, the sludge sources to the container must be understood.

"KE Canister, KE Floor, KW NLOP and KW Floor (with the exception of KW West Bay Floor Sludge) are assigned the same starting state uranium oxide distribution (PNNL-14228, p. 2.9).

KW Canister sludge is more reduced, and consequently, a different starting state uranium oxide distribution is assigned (PNNL$14228, \mathrm{p} 2.9$ )

KW West Bay Floor Sludge (now in SCS-CON-210 and 220) includes some sludge from fuel washing operations, with a fraction originating from KW Canister sludge (Databook Rev 14B, Table 5.1). Therefore, KW Engineered Container sludge includes uranium oxides from both $\mathrm{KE}$ and $\mathrm{KW}$ Canister sludge sources."

The following steps are provided to derive the fraction of uranium oxide in KW Container Sludge that originated as KW Canister Sludge.

From Table 5-1, Databook (Rev 14B), $\quad 49$ vol\% of KW West Bay Floor sludge from KW Can. Sludge. From Fig. 3 of Databook (Rev 14B), West Bay Floor $=\quad 0.54 \mathrm{~m}^{3}$ (orig.) $+\quad 0.57 \mathrm{~m}^{3}$ (added) $=1.11 \mathrm{~m}^{3}$. From Fig. 3 of Databook (Rev 14B), KW Container Sludge $=\quad 5.1 \mathrm{~m}^{3}$.

KW Canister Sludge \& KW Container Sludge uranium comps. given in Tables 4.3 \& 5.2, Databook (Rev 14B). From this input, determine fraction of $\mathrm{U}$ oxide in KW Container Sludge associated with KW Canister Sludge.

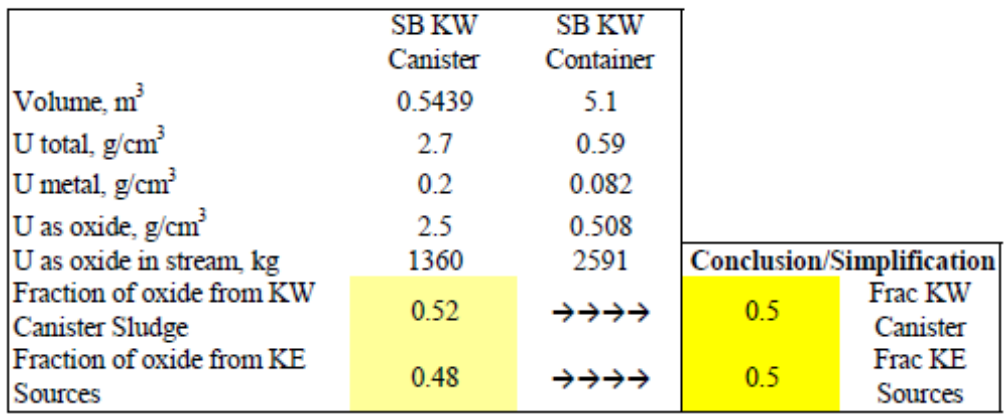


Conclusion: For simplicity, for starting state uranium oxide calculations, the source of uranium oxide in KW Container Sludge can be considered to be a 50/50 mass ratio of KW Canister originating oxide and $\mathrm{KE}$ originating oxide.

Note: Molecular weights, rounded to 3 sig figs; Particle densities from PNNL-14228

Calculation/Data Table for SB KW Container Sludge (Sludge Databook Rev 14B Basis)

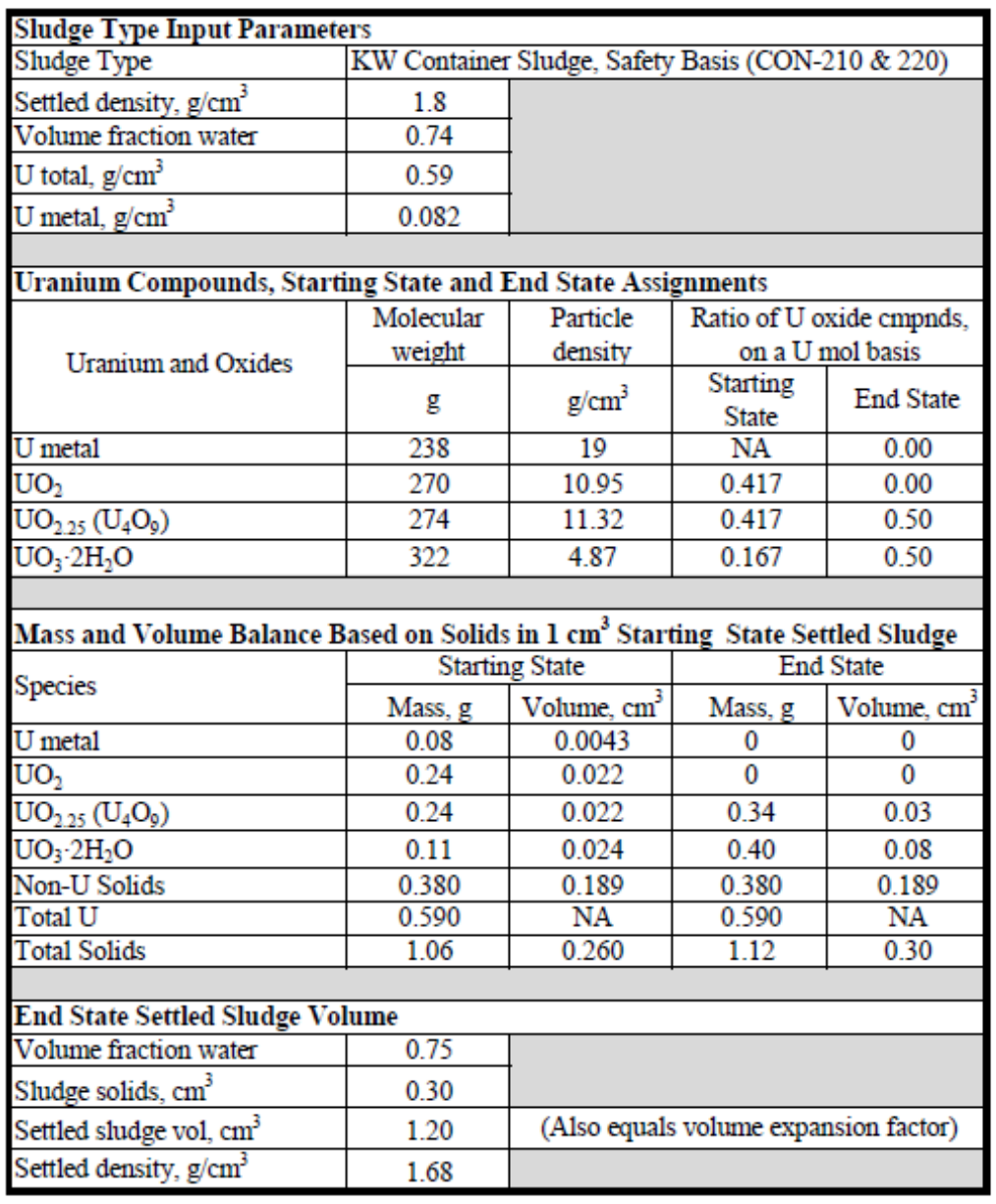

\section{Cross Checks on KW Container Sludge}

Starting state particle density, $\mathrm{g} / \mathrm{cm}^{3}$

End state particle density, $\mathrm{g} / \mathrm{cm}^{3}$

Density check on non U solids, $\mathrm{g} / \mathrm{cm}^{3}$
8.93 (reasonably consistent with PNNL-14228)

6.60 (consistent with PNNL-14228)

2.01 (low, but reasonable) 


\section{Alternative Approach for Expansion Factors (Updated)}

Key Assumptions based on uraninite oxidation (53451-RPT13) and long-term settling (PNNL-15092)

1) U metal corrodes to end state uranium oxide mixture and volume frac water as given in PNNL-14228

2) Oxidation of uranium oxides does not result in growth of settled sludge volume.

3) Therefore, only volume growth associated with $U$ metal oxidation must be accounted for in expansion factors.

4) Need to account for fraction of $U$ oxide from KE Source vs. KW Can for starting state mass balance.

Calculation/Data Table for SB KW Container Sludge (Updated Approach)

Sludge Type Input Parameters

\begin{tabular}{|l|c|}
\hline Sludge Type & KW Container \\
\hline Settled density, $\mathrm{g} / \mathrm{cm}^{3}$ & 1.8 \\
\hline Volume fraction water & 0.74 \\
\hline $\mathrm{U}$ total, $\mathrm{g} / \mathrm{cm}^{3}$ & 0.59 \\
\hline $\mathrm{U}$ metal, $\mathrm{g} / \mathrm{cm}^{3}$ & 0.082 \\
\hline
\end{tabular}

Uranium Compounds, Starting State and End State Assignments

\begin{tabular}{|l|c|c|c|c|}
\hline \multirow{2}{*}{ Uranium and Oxides } & $\begin{array}{c}\text { Molecular } \\
\text { Weight }\end{array}$ & $\begin{array}{c}\text { Particle } \\
\text { Density }\end{array}$ & \multicolumn{2}{|c|}{$\begin{array}{c}\text { Ratio of U oxides } \\
\text { compounds, on a U mol }\end{array}$} \\
\cline { 2 - 5 } & $\mathrm{g}$ & $\mathrm{g} / \mathrm{cm}^{3}$ & $\begin{array}{c}\text { Starting } \\
\text { State }\end{array}$ & End State \\
\hline $\mathrm{U} \mathrm{metal}_{\mathrm{UO}}$ & 238 & 19 & NA & 0.00 \\
\hline $\mathrm{UO}_{2.25}\left(\mathrm{U}_{4} \mathrm{O}_{9}\right)$ & 270 & 10.95 & 0.417 & 0.00 \\
\hline $\mathrm{UO}_{3} \cdot 2 \mathrm{H}_{2} \mathrm{O}$ & 274 & 11.32 & 0.417 & 0.50 \\
\hline
\end{tabular}

Mass and Volume Balance: Basis: Solids in $1 \mathrm{~cm}^{3}$ Starting State Settled Sludge

\begin{tabular}{|l|c|c|c|c|}
\hline \multirow{2}{*}{ Species } & \multicolumn{2}{|c|}{ Starting State } & \multicolumn{2}{c|}{ End State } \\
\cline { 2 - 5 } & Mass, $\mathrm{g}$ & ${\text { Volume, } \mathrm{cm}^{3}}^{\mathrm{a})}$ & Mass, $\mathrm{g}$ & Volume, cm \\
\hline $\mathrm{U}$ metal & 0.08 & 0.0043 & 0 & 0 \\
\hline $\mathrm{UO}_{2}$ & 0.24 & 0.022 & 0 & 0 \\
\hline $\mathrm{UO}_{2.25}\left(\mathrm{U}_{4} \mathrm{O}_{9}\right)$ & 0.24 & 0.022 & 0.34 & 0.03 \\
\hline $\mathrm{UO}_{3} \cdot 2 \mathrm{H}_{2} \mathrm{O}$ & 0.11 & 0.024 & 0.40 & 0.08 \\
\hline Non-U Solids & 0.380 & 0.189 & 0.380 & 0.189 \\
\hline Total Solids & 1.06 & 0.260 & 1.12 & 0.30 \\
\hline
\end{tabular}

End State Settled Sludge Volume ${ }^{(\mathrm{b})}$

\begin{tabular}{|l|l|l|}
\hline Expansion U metal & \\
\cline { 1 - 2 }, $\mathrm{cm}^{(\mathrm{c})} \mathrm{cm}^{3}$ & 0.07 & \\
\hline Settled sludge vol, $\mathrm{cm}^{3}$ & 1.07 & \multirow{2}{*}{ (Also equals volume expansion factor) } \\
\cline { 1 - 2 } Calc. Vol. Frac. Water & 0.72 & \\
Settled density, $\mathrm{g} / \mathrm{cm}^{3}$ & 1.77 &
\end{tabular}

(a) Starting state U oxide ratio based on HNF-SD-SNF-TI-015, Vol 2 Rev 14B. Future updates should consider use of measured $\mathrm{U}$ oxide ratios, based on validated

characterization data.

(b) Proposed approach assumes further oxidation and hydration of uranium oxides do not change end state settled volume.

(c) Volume expansion from $\mathrm{U}$ metal oxidation is addressed using conservative theoretical expansion factor approach. Every gram of $\mathrm{U}$ metal in starting state sludge creates $0.8 \mathrm{~cm}^{3}$ increase in end state settled sludge volume." 
Title

Revision

Date Finalized

Review Status

Date Reviewed

Purpose/Approach
Evaluation of Corrosion Based Volumetric Expansion Factors 0

$10 / 22 / 2010$

Reviewed

$11 / 1 / 2010$ (signed)

Apply approach developed for Settler Sludge Expansion Factor to Calculate the

Expansion Factor of $\mathrm{KE}$ Containerized Sludge, with appropriate input values from the Sludge Databook (Rev 14B).

Calculation Approach for Expansion Factors used in Sludge Databook (HNF-SD-SNF-TI-015, Vol 2 Rev 14a)

Parameter inputs, for KE Container Sludge, Sludge Databook, Rev 14 B, Table 5.2.

Starting State U Oxide Composition, U mol basis mixture. (Basis: SNF-7765 Rev3D Sec. 4, PNNL-14228).

$$
\begin{array}{lcccc} 
& \multicolumn{2}{c}{1 / 3 \mathrm{UO}_{2}+1 / 3 \mathrm{U}_{4} \mathrm{O}_{9}+1 / 3 \mathrm{UO}_{3} \cdot 2 \mathrm{H}_{2} \mathrm{O}} & \mathrm{KE} \text { canister \& } \mathrm{KE} \text { floor sludge starting } \\
\mathrm{KE} \text { Can \& Floor Sludge } & \mathrm{UO}_{2} & \mathrm{UO}_{2.25} & \mathrm{UO}_{3} \cdot 2 \mathrm{H}_{2} \mathrm{O} & \begin{array}{l}
\text { state is an equal uranium mole fraction of } \\
\text { sthese three uranium compounds }
\end{array} \\
0.333 & 0.333 & 0.333 & \text { the }
\end{array}
$$

End State (partially oxic storage) all uranium compounds (Basis: SNF-7765 Rev3D Sec. 4, PNNL-14228).

$$
\begin{array}{lccc}
\text { All U oxides \& U metal } & 1 / 2 \mathrm{U}_{4} \mathrm{O}_{9}+1 / 2 & \mathrm{UO}_{3} \cdot 2 \mathrm{H}_{2} \mathrm{O} & \\
& \mathrm{UO}_{2} & \mathrm{UO}_{2.25} & \mathrm{UO}_{3} \cdot 2 \mathrm{H}_{2} \mathrm{O}
\end{array}
$$

Volume fraction water $\quad 0.75$

Note: All of the Sludge in KE Originating Containers (SCS-CON-240, 250 and 260) is derived from KE sources. Therefore, the $\mathrm{U}$ oxide distribution from $\mathrm{KE}$ Sludge can be used for starting state mass balance calcs.

Note: Molecular weights, rounded to 3 sig figs; particle densities from PNNL-14228. 
Calculation/Data Table for SB KE Container Sludge (Sludge Databook Rev 14B Basis, Table 5.2).

\begin{tabular}{|c|c|c|c|c|}
\hline \multicolumn{5}{|c|}{ Sludge Type Input Parameters } \\
\hline \multirow{2}{*}{ Settled density, $\mathrm{g} / \mathrm{cm}^{3}$} & \multicolumn{4}{|c|}{ KE Container Sludge $(240,250,260)$ Safety Basis } \\
\hline & 1.6 & \\
\hline Volume fraction water & 0.75 & & & \\
\hline $\mathrm{U}$ total, $\mathrm{g} / \mathrm{cm}^{3}$ & 0.38 & & & \\
\hline $\mathrm{U}$ metal, $\mathrm{g} / \mathrm{cm}^{3}$ & 0.030 & & & \\
\hline \multicolumn{5}{|c|}{ Uranium Compounds, Starting State and End State Assignments } \\
\hline \multirow[t]{2}{*}{ Uranium and Oxides } & $\begin{array}{c}\begin{array}{c}\text { Molecular } \\
\text { weight }\end{array} \\
\end{array}$ & \begin{tabular}{|l|} 
Particle \\
density
\end{tabular} & \multicolumn{2}{|c|}{$\begin{array}{c}\text { Ratio of U oxide compounds, } \\
\text { on a U mol basis }\end{array}$} \\
\hline & $\mathrm{g}$ & $\mathrm{g} / \mathrm{cm}^{3}$ & Starting State & End State \\
\hline U metal & 238 & 19 & NA & 0.00 \\
\hline $\mathrm{UO}_{2}$ & 270 & 10.95 & 0.333 & 0.00 \\
\hline $\mathrm{UO}_{2.25}\left(\mathrm{U}_{4} \mathrm{O}_{9}\right)$ & 274 & 11.32 & 0.333 & 0.50 \\
\hline $\mathrm{UO}_{3} \cdot 2 \mathrm{H}_{2} \mathrm{O}$ & 322 & 4.87 & 0.333 & 0.50 \\
\hline \multicolumn{5}{|c|}{ Mass and Volume Balance: Basis: Solids in $1 \mathrm{~cm}^{3}$ Starting State Settled Sludge } \\
\hline \multirow{2}{*}{ Species } & \multicolumn{2}{|c|}{\begin{tabular}{|c|} 
Starting State \\
\end{tabular}} & \multicolumn{2}{|c|}{ End State } \\
\hline & Mass, g & Volume, $\mathrm{cm}^{3}$ & Mass, g & Volume, $\mathrm{cm}^{3}$ \\
\hline U metal & 0.03 & 0.0016 & 0 & 0 \\
\hline $\mathrm{UO}_{2}$ & 0.13 & 0.012 & 0 & 0 \\
\hline $\mathrm{UO}_{2.25}\left(\mathrm{U}_{4} \mathrm{O}_{9}\right)$ & 0.13 & 0.012 & 0.22 & 0.02 \\
\hline $\mathrm{UO}_{3} \cdot 2 \mathrm{H}_{2} \mathrm{O}$ & 0.16 & 0.032 & 0.26 & 0.05 \\
\hline Non-U Solids & 0.395 & 0.192 & 0.395 & 0.192 \\
\hline Total U & 0.380 & NA & 0.380 & $\mathrm{NA}$ \\
\hline Total Solids & 0.85 & 0.250 & 0.87 & 0.26 \\
\hline \multicolumn{5}{|c|}{ End State Settled Sludge Volume } \\
\hline \multicolumn{2}{|c|}{\begin{tabular}{|l|l|} 
Volume fraction water & 0.75 \\
\end{tabular}} & & & \\
\hline Sludge solids, $\mathrm{cm}^{3}$ & 0.26 & & & \\
\hline Settled sludge vol, $\mathrm{cm}^{3}$ & 1.06 & (Also equa & Is volume expa & ion factor) \\
\hline Settled density, $\mathrm{g} / \mathrm{cm}^{3}$ & 1.57 & & & \\
\hline
\end{tabular}

\begin{tabular}{|ll|}
\hline Cross Checks on KE Container Sludge & \\
Starting State avg. density $\left(\mathrm{g} / \mathrm{cm}^{3}\right)$ & 7.53 (consistent with PNNL-14228) \\
End State Density, $\mathrm{g} / \mathrm{cm}^{3}$ & 6.60 (consistent with PNNL-14228) \\
Density check on non U solids, $\mathrm{g} / \mathrm{cm}^{3}$ & 2.06 (low, but reasonable) \\
\hline
\end{tabular}

Alternative Approach for Expansion Factors (Updated)

Key Assumptions based on uraninite oxidation (53451-RPT13) and long-term settling (PNNL-15092)

1) U metal corrodes to end state uranium oxide mixture and volume frac water as given in PNNL-14228.

2) Oxidation of uranium oxides do not result in growth of settled sludge volume.

3) Therefore, only volume growth associated with U metal ox'n. must be accounted for in expansion factors. 
Calculation/Data Table for SB KE Container Sludge (Updated Approach)

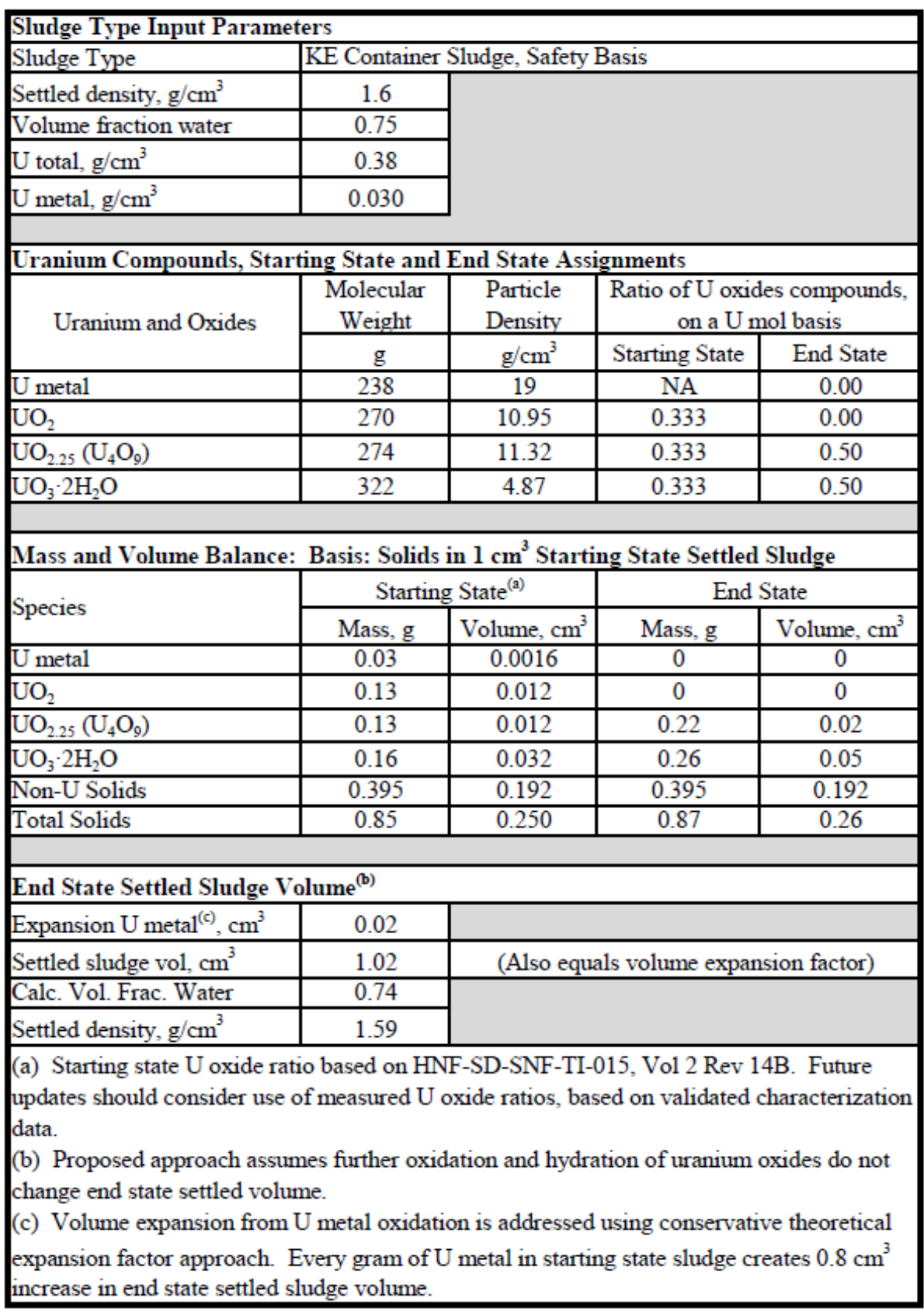

Use for

Table 4.5

53451-RPT13 
Calculation Review Sheet

Reviewer Name: Reviewer Title: Review Date:

\begin{tabular}{l} 
CH Delegard \\
Staff Scientist \\
\hline $10 / 7 / 2010$ to $10 / 18 / 10$
\end{tabular}

Title of Spreadsheets

Calculation Reviewed: Eval of Corrosion Based Vol Expansion Factors.xisx

Revision Number: Rev 0

Date Finalized: $10 / 22 / 2010$

Scope of Spreadsheet Review: (Check one or more of the following)

$\mathrm{x}$ General Validation Review: (General review \& spot checks)

Review of updated spreadsheet/calc (Revised portion only)

$\mathrm{x} 100 \%$ Verification Review (Verification of all cells/calculations)

Other

Independent calculation check (With hand calcs or independent spreadsheet)

\section{CHECK LIST}

Spreadsheet/Calculation Identification

Spreadsheet/Calculation Title:

Revision Number:

Date Prepared

Prepared by:

General Statement of Purpose:

General Description of Approach (note: specific

Comments:

Assumptions

Are assumptions clearly stated?

Are assumptions supported/justified?

Are assumptions reasonable?

Comments:

\begin{tabular}{|c|c|c|}
\multicolumn{1}{c}{ Yes } & \multicolumn{1}{c|}{ No } & \multicolumn{1}{c|}{ NA } \\
\hline$x$ & & \\
\hline$x$ & & \\
\hline$x$ & & \\
\hline$x$ & & \\
\hline$x$ & & \\
\hline \multicolumn{4}{|c}{} \\
\hline
\end{tabular}

Input Values

Are input parameters correct (verified with source?)

Are parameter units consistent?

Are input values properly referenced?

Comments:

\begin{tabular}{|c|c|c|}
\multicolumn{1}{c}{ Yes } & \multicolumn{1}{c}{ No } & \multicolumn{1}{c|}{ NA } \\
\hline $\mathrm{x}$ & & \\
\hline $\mathrm{x}$ & & \\
\hline $\mathrm{x}$ & & \\
\hline
\end{tabular}

\section{Equations/Approach}

Are equations adequately defined?

Are equations properly referenced?

Are limitations of approach/equations identified?

Are equations appropriate?

Are units consistent?

\begin{tabular}{|c|c|c|} 
Yes & \multicolumn{1}{c}{ No } & \multicolumn{1}{c|}{ NA } \\
\hline$x$ & & \\
\hline$x$ & & \\
\hline$x$ & & \\
\hline
\end{tabular}

Comments:

\section{Results/Conclusions}

Are formulas consistent in spreadsheet cells?

Are calculations correct?

Are conclusions consistent with results?

Are conclusions consistent with appticable limits?

Comments:

Reviewer Signature/Date:

\begin{tabular}{|c|l|l|}
\multicolumn{1}{c}{ Yes } & \multicolumn{1}{c}{ No } & \multicolumn{1}{c|}{ NA } \\
\hline $\mathrm{x}$ & & \\
\hline & & $\mathrm{x}$ \\
\hline $\mathrm{x}$ & & \\
\hline $\mathrm{x}$ & & \\
\hline $\mathrm{x}$ & & \\
\hline
\end{tabular}

\begin{tabular}{|c|l|l|}
\multicolumn{1}{c}{ Yes } & \multicolumn{1}{c}{ No } & \multicolumn{1}{c}{ NA } \\
\hline $\mathrm{x}$ & & \\
\hline $\mathrm{X}$ & & \\
\hline $\mathrm{x}$ & & \\
\hline $\mathrm{x}$ & & \\
\hline
\end{tabular}

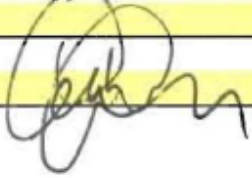


PNNL-20100

53451-RPT13

\section{Distribution}

No. of

Copies

Internal Distribution

12 Pacific Northwest National Laboratory

$\begin{array}{lr}\text { CA Burns } & \text { P7-25 } \\ \text { CD Carlson } & \text { P7-25 } \\ \text { RC Daniel } & \text { P7-22 } \\ \text { CH Delegard } & \text { P7-25 } \\ \text { SK Fiskum } & \text { P7-25 } \\ \text { PA Gauglitz } & \text { K7-15 } \\ \text { Y Onishi } & \text { K7-15 } \\ \text { AJ Schmidt } & \text { P8-60 } \\ \text { RW Shimskey } & \text { P7-25 } \\ \text { SI Sinkov } & \text { P7-25 } \\ \text { BE Wells } & \text { K7-15 } \\ \text { Project File } & \text { K3-52 } \\ \text { Information Release (pdf) } & \end{array}$

12 CH2M HILL Plateau Remediation

Company

\begin{tabular}{ll} 
RB Baker & A3-06 \\
DA Burbank & A0-26 \\
GR Franz & A3-06 \\
DW Hamilton & A3-06 \\
SR Hill & A3-06 \\
JO Honeyman & A3-06 \\
ME Johnson & A0-26 \\
H Mashaw & A0-26 \\
RE Raymond & A0-26 \\
WW Rutherford & A3-06 \\
JP Sloughter & A3-06 \\
STP Project File, & \\
\multicolumn{1}{c}{ (FE Wickstrand) } & R1-29
\end{tabular}

Distr. 1 


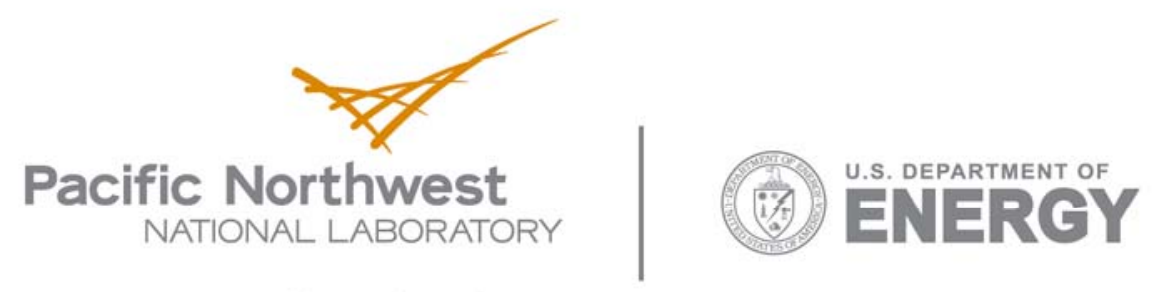

902 Battelle Boulevard

P.O. Box 999

Richland, WA 99352

1-888-375-PNNL (7665)

www.pnl.gov 